\title{
Site U1325
}

\author{
Expedition 311 Scientists $^{2}$
}

\section{Chapter contents}

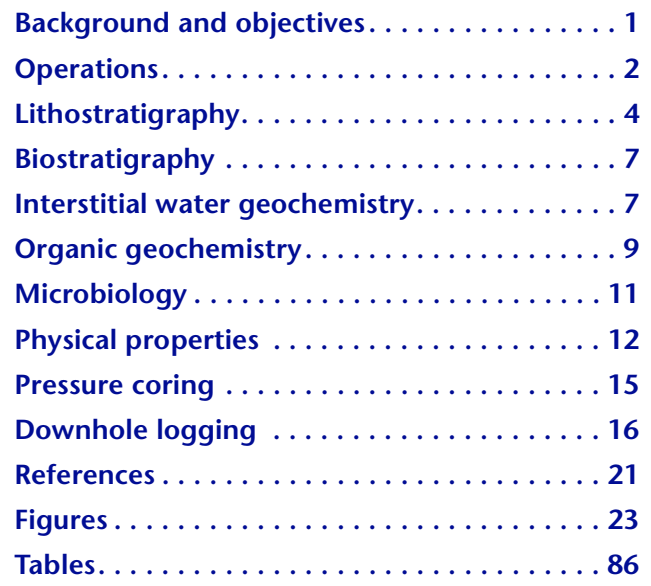

${ }^{1}$ Expedition 311 Scientists, 2006. Site U1325. In Riedel, M., Collett, T.S., Malone, M.J., and the Expedition 311 Scientists. Proc. IODP, 311: Washington, DC (Integrated Ocean Drilling Program Management International, Inc.). doi:10.2204/iodp.proc.311.103.2006 'Expedition 311 Scientists' addresses.

\section{Background and objectives}

Site U1325 (proposed Site CAS-02C; Collett et al., 2005) is located along the margin-perpendicular transect established during Integrated Ocean Drilling Program (IODP) Expedition 311 and is within the first major slope basin that developed eastward of the deformation front behind a steep ridge of accreted sediments (see Fig. F3 in the "Expedition 311 summary" chapter). The bathymetry data show that the seafloor in the western part of the basin is relatively flat with water depths of $\sim 2200 \mathrm{~m}$ (see Fig. F4 in the "Expedition 311 summary" chapter). Around Site U1325, the seafloor becomes gradually shallower before it rises rapidly to the east to form the plateau of the second main accreted ridge at water depths of $\sim 1200 \mathrm{~m}$, on which IODP Site U1327 and Ocean Drilling Program (ODP) Site 889 are located. A map of the seismic site survey data around Site U1325 is shown in Figure F1.

The western part of the slope basin is seismically characterized by a section as thick as $600 \mathrm{~ms}$ two-way traveltime (TWT) of relatively undisturbed slope basin-type sediments with almost seafloor-parallel reflectivity (common depth points [CDPs] 11801320 in Fig. F2). Toward the eastern part of the basin, a buried ridge of accreted sediments is visible (CDPs 1320-1440 in Fig. F2), covered only by a thin $(20 \mathrm{~m})$ section of more recent slope basin-type sediments. On high-resolution $3.5 \mathrm{kHz}$ subbottom profiler data, Holocene sediments are visible as a 3-5 $\mathrm{m}$ thick transparent layer on top of sediments with stronger reflectivity that do not show any further layering (Fig. F3). The top $20 \mathrm{~m}$ thick sediment section is undisturbed and overlies a $\sim 200 \mathrm{~m}$ thick section of steeply northeast-dipping sediments. The dip is the result of the uplift associated with an underlying ridge of accreted material, which outcrops at the seafloor $\sim 8 \mathrm{~km}$ to the southeast of Site U1325. The sediments forming the ridge of accreted material show laterally limited chaotic reflections that can be traced for only a few hundred meters. The transition between folded, but still coherent, slope sediments to accreted sediments is gradational and not clearly defined at this site. Within the center of the accreted ridge, a section of bright reflections can be seen (CDPs 1350-1360 in Fig. F2; CDPs 7400-7600 in Fig. F4). The short reflection, best imaged in the lower-frequency data of Line 89-08, appears to have a polarity opposite to that of the seafloor, which may indicate the presence of free gas. Interestingly, the high-resolution $3.5 \mathrm{kHz}$ data show a zone of reduced reflectivity (near shot- 
point 1650), similar to that observed at cold vent field Site U1328. There may be a connection between the deeper-seated free gas and this near-seafloor expression of potential fluid/gas expulsion. The location of Site U1325 was chosen carefully to avoid this bright reflector and the near-seafloor expression of the potential expulsion feature.

A bottom-simulating reflector (BSR) is clearly visible in the eastern part of the slope basin (Fig. F2), but it fades to the west (CDPs 1180-1280 along multichannel seismic [MCS] Line 89-08) close to the crossing point with MCS Line 89-11. A BSR may be present in the western basin, but it could also be masked by regular seafloor-parallel stratigraphy. The BSR also shows the typical frequency-dependent reflection strength pattern (Chapman et al., 2002). On MCS Line PGC9902_ODP-7 (Fig. F5), virtually identical in location with Line 89-08, the BSR is barely visible (Fig. F4). The data of Line 89-08 are between 10 and $50 \mathrm{~Hz}$, whereas the data of Line PGC9902_ODP-7 contain frequencies twice as high. This frequencydependent behavior can be explained by a gradient zone of a few meters over which seismic velocity decreases from the gas hydrate-bearing section to the free-gas zone beneath the interface.

At Site U1325, the BSR is less strong (in both the lowand high-frequency data sets) than at the core of the buried ridge of accreted sediments (Figs. F2, F4). The BSR appears to be at 230 meters below seafloor (mbsf) based on seismic traveltime depth conversion, using an average $P$-wave velocity of $1636 \mathrm{~m} / \mathrm{s}$. This average velocity was determined at ODP Leg 146 Site 889 to match observed traveltime depths of the BSR and vertical seismic profile (VSP) data (MacKay, 1994). We acknowledge that this velocity may not be appropriate in this setting; however, lack of good control in seismic interval velocities from MCS semblance analyses of Lines 89-08 and PGC9902_ODP-7 prohibited a more accurate depth migration of the data. Using an extreme velocity profile, which represents no gas hydrate in the section (Hyndman et al., 2001), yields an average velocity of $1619 \mathrm{~m} / \mathrm{s}$, and consequently, the BSR is only $2.5 \mathrm{~m}$ shallower. Alternatively, a much higher velocity profile, which represents twice the amount of gas hydrate of what has been seen at Site 889 , results in a BSR depth that is $2.5 \mathrm{~m}$ deeper.

The primary research objectives for this site are linked to the overriding transect-concept of this expedition. The objectives include

- Studying the distribution of gas hydrate,

- Defining the nature of the BSR,

- Developing baseline geochemical and microbiological profiles, and
- Obtaining data needed to ground-truth remotely acquired imaging techniques such as seismic or controlled-source electromagnetic (CSEM) surveys.

The slope basin is expected to show a different geochemical regime and related geophysical properties than the uplifted ridges of accreted sediments.

The operational plan to achieve these objectives was based on a general three-hole concept, which included

- A logging-while-drilling/measurement-while-drilling (LWD/MWD) hole;

- A continuously cored hole to characterize geochemical and microbiological baselines and proxies for gas hydrate;

- An additional "tools" hole for specialized pressure coring systems, including the IODP Pressure Core Sampler (PCS), HYACINTH Fugro Pressure Corer (FPC), and HYACE Rotary Corer (HRC) systems, combined with selected spot-coring using the conventional extended core barrel (XCB) system; and

- A wireline logging program in the tools hole using the triple combination and Formation MicroScanner (FMS)-sonic tool strings.

\section{Operations}

\section{Transit to Site U1325}

The science portion of Expedition 311 officially began with the first line ashore in Astoria, Oregon (USA), at $1306 \mathrm{~h}$ on 15 September 2005. After completing port call activities, we departed Astoria at $0944 \mathrm{~h}$ on 19 September. The $188 \mathrm{nmi}$ transit to Site U1325 was completed in $19.5 \mathrm{~h}$ at an average speed of $9.6 \mathrm{kt}$. Our initially planned drilling location was scheduled to be proposed Site CAS-03B (Collett et al., 2005), but a large slump identified from newly available multibeam data led us to switch priority to alternate Site U1326 (proposed Site CAS-03C). Approval depth (from IODP's Environmental Protection and Safety Panel and territorial authorities) at Site U1326 was $300 \mathrm{mbsf}, 50 \mathrm{~m}$ shallower than our preferred penetration to ensure that the entire LWD/MWD tool string penetrated through the interval of interest. Therefore, we decided to change the drilling sequence, occupying Site U1325 prior to Site U1326, to allow more time for approval of the late depth-extension request, which did not arrive before completion of the hole.

\section{Hole U1325A}

The LWD/MWD tool string was assembled upon arrival on site, and the drill string was run to the sea- 
floor. During function testing of the tool string, a leak in the top drive swivel wash pipe packing was discovered, which required $1.5 \mathrm{~h}$ to repair. Hole U1325A was spudded at $2310 \mathrm{~h}$ on 20 September 2005, at a seafloor depth of 2212.0 meters below rig floor (mbrf). Initial spud-in parameters were set at 290 gallons per minute (gpm) circulation and 10-20 $\mathrm{rpm}$, which was increased to $40 \mathrm{rpm}$ at $10 \mathrm{mbsf}$, and then again to $60 \mathrm{rpm}$ at 29 mbsf to maintain a $25-30$ $\mathrm{m} / \mathrm{h}$ rate of penetration (ROP) while also maintaining a minimum of $290 \mathrm{gpm}$ circulation. The hole was logged to 350 mbsf without incident and within the prescribed protocol guidelines, requiring no corrective actions (see "Downhole logging" in the "Methods" chapter). After displacing the hole with $10.5 \mathrm{ppg}$ sepiolite mud, the drill string was tripped to the rig floor so that the digital log data from the LWD/MWD logging tools could be downloaded while transiting in dynamic positioning mode to Site $\mathrm{U} 1326$. The bit cleared the rotary table at $0515 \mathrm{~h}$ on 22 September, officially ending operations in Hole U1325A.

\section{Hole U1325B}

After pulling the drill pipe back to 1000 mbrf, the ship was moved $5.5 \mathrm{nmi}$ in dynamic positioning mode from Site U1328 to Site U1325. The arrival time was 1430 h on 17 October 2005 (Fig. F6). Prior to starting the hole, a water-sampling temperature probe (WSTP) water sample was collected. Hole U1325B was spudded with the advanced piston corer (APC) system at $1910 \mathrm{~h}$. The estimated water depth was 2194.9 meters below sea level (mbsl; 2206.2 mbrf), although the core was almost a full core (see "Hole U1325D") (Table T1). When attempting to recover Core $2 \mathrm{H}$, the inner core barrel became stuck near the drill bit. It took several hours to work the core barrel loose. The core barrel was returned slightly bent with a kinked wireline. The second APC core contained a relatively large amount of fine sand, which probably caused the barrel to rebound. As a result, the top of the APC assembly became entangled with the wireline. After replacing part of the barrel assembly and reterminating the coring wireline, an XCB core barrel was deployed to work the hole below the sand section identified in the second APC core.

The hole was advanced by combination of APC, $\mathrm{XCB}$, and pressure coring systems to a depth of 206.5 mbsf. Three deployments of the third-generation advanced piston corer temperature (APCT-3) tool returned very high quality data (Table T1). At 71.5 mbsf, we had an incomplete stroke of the APC system for Core $8 \mathrm{H}$ and switched to XCB coring. A Davis-Villinger Temperature Probe (DVTP) run at
140.5 mbsf yielded high-quality temperature data. Recovery dropped dramatically in the last three $\mathrm{XCB}$ cores, averaging 6\% (Table T1). During Hole U1325B operations at $1230 \mathrm{~h}$ on 18 October, marine mammal observer, Scott Toews, departed the ship by helicopter.

Five pressure coring tools were deployed in Hole U1325B. The first PCS coring run was taken at 82.4 mbsf but did not return with a pressurized core. The HRC was deployed at 129.9 and 197.4 mbsf, but both runs failed to return core under pressure. We also deployed the FPC at 169.4 mbsf, but it did not retrieve a pressurized core. The last PCS deployment was at 206.1 mbsf, but the tool became jammed in the bottom-hole assembly (BHA) after penetrating just $40 \mathrm{~cm}$ into the formation. Hole U1325B was terminated after four unsuccessful tool recovery attempts. Operations in Hole U1325B officially ended at $2125 \mathrm{~h}$ on 19 October when pipe was tripped back to the seafloor. Upon inspection, the PCS bit appeared to have overheated, which caused some melting and enlarged the bottom of the barrel enough to prevent it from being pulled back in the pipe.

\section{Hole U1325C}

After checking for potential problems with the BHA, the drill string was tripped to the seafloor, and Hole U1325C was spudded at $0820 \mathrm{~h}$ on 20 October 2005. The hole was drilled to $188 \mathrm{mbsf}$, where core recovery in Hole U1325B began to deteriorate. Coring operations resumed with the deployment of the XCB system at $2115 \mathrm{~h}$, and the first core contained only $3.28 \mathrm{~m}$ of sediment. We decided to try cutting XCB half-cores to see if this would increase core recovery. The first short XCB core recovered only $0.73 \mathrm{~m}$ of sediment, and the second one recovered none. Thereafter, we decided to switch back to standard full-length XCB core deployments. XCB coring operations interspersed with two pressure coring runs and two DVTP deployments deepened the hole to a total depth (TD) of $304.3 \mathrm{mbsf}$. The last core was brought on deck at $0715 \mathrm{~h}$ on 22 October. An FPC pressure core was deployed at a depth of $217.6 \mathrm{mbsf}$, but it did not return with sediment under pressure. A PCS pressure core was successfully recovered from 256.1 mbsf. The DVTP tool was deployed at 218.6 and 275.6 mbsf.

To prepare for logging, a mud sweep and wiper trip were conducted. The hole was displaced with weighted mud, and the pipe was pulled to logging depth (76.2 mbsf). During the previous evening and early morning hours of 22 October, sea state severely deteriorated and resulted in a sustained ship heave of $5 \mathrm{~m}$. After reviewing the weather forecast and discussing options, we decided that two separate log- 
ging runs would be attempted with tools without calipers to reduce the potential risk of tool string damage. The first run included the Phasor Dual Induction Tool (DIT) and the Hostile Environment Gamma Ray Sonde (HNGS). The second run included the Dipole Sonic Imager (DSI), the Scintillation Gamma Ray Tool (SGT), and the Temperature/ Acceleration/Pressure (TAP) tool. The first tool string was run in the hole at $1325 \mathrm{~h}$, but we were only able to lower it to $259.8 \mathrm{mbsf}, 44.5 \mathrm{~m}$ shallower than total coring depth. The run was successfully completed despite some difficulty reentering the drill pipe past the flapper valve, and the first tool string was back on deck at $1800 \mathrm{~h}$. The modified sonic tool string (without the FMS) was deployed at $2000 \mathrm{~h}$, but it reached a TD of only 185.8 mbsf. The available hole was logged successfully. The repeat pass of the sonic tool string reached $183.0 \mathrm{mbsf}$ and the tool was back to the rig floor at $0030 \mathrm{~h}$. After rigging down logging, the bit was pulled clear of the seafloor at 0200 h on 23 October, ending operations in Hole U1325C.

\section{Hole U1325D}

To ensure that a mudline core was obtained at Site U1325, one APC core was taken with the bit at 2200.0 mbrf. Hole U1325D was spudded at $0335 \mathrm{~h}$ on 23 October 2005. Core $1 \mathrm{H}$ recovered $4.69 \mathrm{~m}$ and indicated a seafloor depth of 2193.2 mbsl (2204.8 mbrf). This depth suggested that Hole U1325B was initiated $\sim 1.4 \mathrm{~m}$ below the seafloor. The heave state throughout Site U1325 operations, however, was $3 \mathrm{~m}$ or higher, increasing the uncertainty of seafloor depth calculations using the recovery of the mudline core. Shipboard analyses of Core $1 \mathrm{H}$ indicated that Hole U1325B may have missed the mudline by as much as $\sim 2.5 \mathrm{~m}$ (see "Interstitial water geochemistry"). The drill pipe was pulled clear of the seafloor at $0430 \mathrm{~h}$ on 23 October, ending operations at Site U1325.

\section{Lithostratigraphy}

Site U1325 is located within the first slope basin in the southwestern part of the Expedition 311 transect. Three of the four holes (Holes U1325AU1325D) at this site were cored: Hole U1325B was cored to $206.5 \mathrm{mbsf}$ ( $205.5 \mathrm{~m}$ cored), Hole U1325C to $304.3 \mathrm{mbsf}$ ( $115.5 \mathrm{~m}$ cored), and Hole U1325D to $4.7 \mathrm{mbsf}$ ( $4.7 \mathrm{~m}$ cored). Recovery was excellent in Hole U1325D (99.8\%), good in Hole U1325B (68.3\%), but more limited in Hole U1325C (53.3\%).

We divided the $304.3 \mathrm{~m}$ thick sedimentary section recovered from Holes U1325B and U1325C into four lithostratigraphic units (Fig. F7) based on visual inspection of the recovered cores and analysis of smear slides. Other parameters, such as mineralogy data from X-ray diffraction (XRD) analyses, helped to better define the entire stratigraphic section. The results were also compared and correlated with seismic data, downhole LWD/MWD data, and physical property measurements.

\section{Lithostratigraphic units}

\section{Lithostratigraphic Unit I}

Intervals: Sections 311-U1325B-1H-1 through 6H7; 311-U1325D-1H-1 through 1H-CC

Depths: Hole U1325B: 0.00-52.23 mbsf; Hole U1325D: 0.00-4.69 mbsf

Age: Holocene to Pleistocene $(<0.3 \mathrm{Ma})$

The sediments recovered in Unit I were divided into two subunits based on grain-size distribution and occurrence of bioturbation, sulfide mottles, and sponge spicules. Compared with Subunit IB, the sediments of Subunit IA are dominated by thick sand layers (as thick as $\sim 2.5 \mathrm{~m}$ ).

\section{Subunit IA}

Interval: Sections 311-U1325B-1H-1 through 3X$\mathrm{CC}$

Depth: 0.00-24.00 mbsf

Age: Holocene to Pleistocene $(<0.3 \mathrm{Ma})$

Subunit IA is mainly composed of dark greenish gray (5GY 4/1) silty clay with diatoms, diatom silty clay, silty clay, and black (N2.5) sand. Sand layers have mostly sharp (Fig. F8) and some erosional contacts. The single layers show varying thickness from a few millimeters to several meters (Fig. F9). The layers show fining-upward sequences in Sections 311U1325B-1H-5, 1H-7, and 2H-5. The major nonbiogenic components of Subunit IA are clay minerals, quartz, feldspar, opaque minerals, accessory minerals (mainly amphibole), biotite, and some rock fragments. Rare to abundant sulfide mottling, appearing as dark gray (N4) stains, occurs in Sections 311U1325B-1H-2, 1H-4, 2H-4, 2H-5, 2H-7, and 3H-1.

The major biogenic components of Subunit IA are diatoms, as much as 30\% in Sample 311-U1325B-1H$2,30 \mathrm{~cm}$. Bivalve shell fragments are visually observed in Sections 311-U1325B-1H-4, 1H-2, and 1H7; sponge spicules in Section $1 \mathrm{H}-2$; and foraminifers in Section 3X-1.

Sedimentary structures related to soft-sediment deformation are observed in interval 311-U1325B-2H$5,84-110 \mathrm{~cm}$. Dropstones are present in Sections 311-U1325B-2H-2, 2H-6, and 2H-7 (Fig. F10). Some small concretions $(<3 \mathrm{~mm})$ are present in Sections 311-U1325B-2H-5 and 2H-7. 


\section{Subunit IB}

Interval: Sections 311-U1325B-4H-1 through 6H-7

Depth: 24.00-52.23 mbsf

Age: Pleistocene $(<0.3 \mathrm{Ma})$

Subunit IB is mainly composed of dark greenish gray (5GY 4/1) silty clay with diatoms, diatom silty clay, and silty clay. Minor lithologies are silt and sand-siltclay. The major nonbiogenic components of Subunit IB are clay minerals, quartz, feldspar, opaque minerals, some accessory minerals (mainly amphibole), and biotite. A volcanic ash lens is present in Section 311-U1325B-6H-3 (Fig. F11). This lens might correlate to a volcanic ash layer found in Hole U1328B (interval 311-1328B-9H-5, 142-144 cm). Using the given sedimentation rates (see "Biostratigraphy"), the ash in Hole U1325B has an approximate age of $108 \mathrm{ka}$, whereas the layer in Hole U1328B has an approximate age of $122 \mathrm{ka}$. Note that these ages are rough estimates and give only the time of deposition, not the time of eruption, because these are most likely turbiditic, reworked deposits.

Subunit IB shows abundant sulfide mottling (Fig. F12), which often coincides with abundant bioturbation. Abundant iron sulfide concretions are observed in Sections 311-U1325B-4H-1 through 4H-4, 5H-1 through 5H-4, 5H-7, 6H-2, 6H-3, 6H-6, and $6 \mathrm{H}-7$. Greenish spots of glauconite are present as dispersed grains in Sections 311-U1325B-5H-2, 6H-1, and 6HCC.

In the major lithology, diatoms (as much as 30\%) and sponge spicules (Figs. F13, F14) (Sections 311U1325B-4H-1 through 5H-2 and $6 \mathrm{H}-1$ through $6 \mathrm{H}-6$ ) are abundant, whereas calcareous fossils are almost absent in smear slides. A wood fragment was observed in Section 311-U1325B-4H-7, visible foraminifers in Sections $4 \mathrm{H}-7$ and $5 \mathrm{H}-2$, and bivalve shell fragments in Section $5 \mathrm{H}-2$.

Fractures in the core caused by gas expansion are common in Sections 311-U1325B-5H-1 through 5H3 and $5 \mathrm{H}-6$. Mousselike texture related to the presence of gas hydrate is present in intervals 311U1325B-5H-7, 26-26.5 cm, and 5H-7, 29.5-30.5 cm. The Unit I/II boundary is marked by an absence of diatoms, bioturbation, less intense sulfide mottles, and a sharp decrease in the occurrence of sponge spicules.

\section{Lithostratigraphic Unit II}

Interval: Sections 311-U1325B-6H-CC through 13X-CC

Depth: 52.23-102.30 mbsf

Age: Pleistocene $(>0.3$ and $<1.0 \mathrm{Ma})$

Unit II is composed of dark gray (N4) clay, dark gray (N4) and dark greenish gray (5GY 4/1) silty clay, and clayey silt locally interbedded with frequent dark gray (N4) quartz sand, very dark gray (N3) silty sand, and dark gray (N4) sandy silt layers (Fig. F15). Silty or sandy layers show fining-upward sequences in Sections 311-U1325B-7H-4 and 8H-1 through 8H-4 (Fig. F15). The frequency of the coarser-grained layers is about every 5 to $10 \mathrm{~cm}$ in Sections 311-U1325B $7 \mathrm{H}-3$ through $7 \mathrm{H}-5,8 \mathrm{H}-1$ through $8 \mathrm{H}-4$, and $12 \mathrm{H}-1$. The major nonbiogenic components of Unit II are clay minerals, quartz, feldspar, accessory minerals (mainly amphibole), opaque minerals, and biotite. Rare to moderate sulfide mottling is observed throughout Cores 311-U1325B-7H to 13X. Small sulfide concretions are present in Section 311-U1325B$10 \mathrm{X}-1$, and a glauconite-rich patch is seen in Section $10 \mathrm{X}-2$. A rounded dropstone $(0.8 \mathrm{~cm})$ is observed in Section 311-U1325B-7H-4. A white piece of pumice $(1 \mathrm{~cm})$ was found in an interstitial water (IW) sample (Sample 311-U1325B-7H-4, 150-165 cm).

Biogenic components, observed in smear slides, are almost absent in Unit II. Visually, we observed aggregates of sponge spicules in Sections 311-U1325B10X-1 through 10X-3 and bivalve shell fragments in Section 10X-2.

A small-scale sedimentary structure related to softsediment deformation is observed in interval 311U1325B-7H-4, 67-70 cm. Major core disturbance is present in Sections 311-U1325B-8H-6 and 8H-7, with vertically arranged sand layers. This was probably related to the stiff nature of the sediment and resulting partial stroke of the APC corer, at which point coring was changed to the XCB system. Mousselike texture related to the presence of gas hydrate is present in intervals 311-U1325B-8H-1, 91-93 cm; 8H-2, 36-38 $\mathrm{cm}$; and $11 \mathrm{P}-1,0-20 \mathrm{~cm}$. The Unit II/III boundary is marked by a strong increase in diatoms (see "Biostratigraphy") and an increase in induration of the sediments, which shows in the occurrence of drilling biscuits and a sudden increase in aggregates of sponge spicules.

\section{Lithostratigraphic Unit III}

Intervals: Sections 311-U1325B-14X-1 through 25X-CC and 311-U1325C-1X-1 through 1XCC

Depths: Hole U1325B: 102.30-197.40 mbsf and Hole U1325C: 188.80-198.40 mbsf

Age: Pleistocene $(>0.3 \mathrm{Ma})$

Unit III is mainly composed of dark greenish gray (5GY 4/1) and dark gray (N4) clay, silty clay, silty clay with diatoms, diatom silty clay, nannofossil silty clay, clayey silt with diatoms, silty clay, diatom ooze, and nannofossil ooze. In the upper part of Unit III, from Section 311-U1325B-14X-1 to 19X-CC (102.30-145.98 mbsf), dark greenish gray (5GY 4/1) 
and dark gray (N4) silty clay, clayey silt with diatoms, and diatom clayey silt are the main lithologies. Nannofossil ooze and nannofossil silty clay occur between 140.50 and 145.98 mbsf. The lower part of Unit III, from Section 311-U1325B-20X-1 to 25X-CC (150.20-197.40 mbsf), is mainly dominated by dark gray (N4) silty clay and silty clay with diatoms associated with dark greenish gray (5GY 4/1) silty diatom ooze in Sections 311-U1325B-24X-4 and 24X-5 (183.27-185.72 mbsf). Coarser-grained silt, sandy silt, sand, quartz sand, and foraminifer silty sand occur as minor lithologies in Cores 311-U1325B-14X through 16X, 20X through 24X, and 311-U1325C$1 \mathrm{X}$. Fining-upward sequences and planar laminations (Fig. F16) are observed in Sections 311-U1325B$14 \mathrm{X}-4$ through $14 \mathrm{X}-6,15 \mathrm{X}-1,15 \mathrm{X}-3,16 \mathrm{X}-4,19 \mathrm{X}-3$, 19X-5, 20X-4, 21X-CC, 24X-1, 24X-2, 24X-4, and $24 \mathrm{X}-5$.

The major nonbiogenic components of Unit III are clay minerals, quartz, feldspar, accessory minerals, opaque minerals, and biotite. Sulfide mottling is present in Sections 311-U1325B-14X-1, 14X-4, 14X5, 20X-2, 20X-4, 21X-1, 21X-2, and 24X-1. Glauconite-rich patches are observed in Sections 311U1325B-16X-2, 16X-3, 16X-6, and 16X-7. A dark greenish gray (5GY 4/1), round rock fragment $(2 \mathrm{~cm}$ $\times 3 \mathrm{~cm}$ ), probably a dropstone, is present in Section 311-U1325B-14X-5.

The biogenic components are distinctly different from Unit II. The major lithology shows a high content of diatoms, as high as 50\% in Sample 311U1327B-24X-4, $34 \mathrm{~cm}$. The most important carbonate fossils are nannofossils (Fig. F17). Sample 311U1325B-19X-1, $100 \mathrm{~cm}$, has the composition of a nannofossil ooze (60\% nannofossils). Visually observed aggregates of sponge spicules are present in Cores 311-U1325B-14X through 20X. Bioturbation is only present in Sections 311-U1325B-14X-1 and $14 \mathrm{X}-2$.

A layer of carbonate cement occurs in interval 311U1325B-16X-6, 27-33 cm. XRD analysis confirmed a combination of high-Mg calcite $\left(12 \mathrm{~mol} \% \mathrm{MgCO}_{3}\right)$ and a nonstoichiometric dolomite (44 mol\% $\mathrm{MgCO}_{3}$ ). Soupy and mousselike sediment textures related to the presence of gas hydrate are present in Sections 311-U1325B-16X-1, 18X-1, and 19X-5 (Fig. F18). The Unit III/IV boundary is marked by the sudden absence of diatoms (see "Biostratigraphy").

\section{Lithostratigraphic Unit IV}

Intervals: Sections 311-U1325B-26E-1 through 28P-1 and 311-U1325C-2X-1 through 15XCC

Depths: Hole U1325B: 197.40-206.56 mbsf and Hole U1325C: 198.40-299.17 mbsf
Age: Pleistocene (>0.3 Ma)

Unit IV is mainly composed of dark gray (N4) and dark greenish gray (5GY 4/1) clay and silty clay, locally interbedded with dark gray (N4) sand, quartz sand, silty sand, sandy silt, silt layers, dark greenish gray (5GY 4/1) silt layers, and dark greenish gray (5GY 4/1) and olive-gray (5Y 3/1) clayey silt. Silty or sandy layers show fining-upward sequences and sharp bottom contacts in Sections 311-U1325C-6X4, 7X-2, 7X-3, and 7X-7 (Fig. F19). Drilling biscuits and other coring-related disturbance features are present almost in the whole unit.

The major nonbiogenic components of Unit IV are clay minerals, quartz, feldspar, biotite, accessory minerals, and opaque minerals. Sulfide mottling is mainly observed in Cores 311-U1325C-8X and 11X, and small sulfide concretions are present in Section 311-U1325C-8X-5 (Fig. F20).

Biogenic components identified from smear slide analyses are almost absent. In IW Sample 311U1325C-15X-3, 60-65 cm, a well-preserved brittle star is present (Fig. F21).

A lithified carbonate piece $(4 \mathrm{~cm})$ occurs in Section 311-U1325C-11X-1.

Mousselike textures typical of the presence of gas hydrate are present in intervals 311-U1325C-7X-3, 72$78 \mathrm{~cm}$, and 8X-5, 80-90 cm (Figs. F19, F22), even though they are below the stability field for gas hydrate. This discrepancy, which is observed in other measurements as well (see "Interstitial water geochemistry" and "Physical properties"), will be addressed postcruise.

\section{Environment of deposition}

Drilling at Site U1325, located within the first slope basin of the northern Cascadia accretionary prism ( $2193 \mathrm{mbsl})$, recovered a sequence that corresponds to slope basin sediments (see "Background and objectives").

Lithostratigraphic Unit IV is characterized by finegrained (clay to silty clay) detrital sediments with few silty/sandy interlayers from turbiditic deposits. The poor recovery at the top and bottom of this unit, as well as the biscuiting of the sediments, limit the observation of sedimentary structures. The few coarser grained layers, however, indicate low-energy turbidity currents.

Lithostratigraphic Unit III is characterized by finegrained (clay to silty clay) detrital sediments with abundant sponge spicule remains and marine and nonmarine diatoms (see "Biostratigraphy"), as well as abundant nannofossils. We interpret this interval as mixed hemipelagic-turbiditic sediments. The pres- 
ence of authigenic carbonate cement suggests that diagenetic processes are active in Unit III.

Lithostratigraphic Unit II is characterized by finegrained (clay to silty clay) detrital sediments with intervals of frequent silty/sandy interlayers. We interpret the coarser interlayers as turbiditic deposits. Their frequent occurrence might indicate times of active tectonism and uplift or maybe earthquakes.

Lithostratigraphic Subunit IB is characterized by fine-grained (clay to silty clay) detrital sediments with few thin silty/sandy interlayers from turbidites. The occurrence of only marine diatoms (see "Biostratigraphy") suggests that the terrigenous sediment flux was somehow restricted. In addition, the occurrence of abundant bioturbation and sulfide mottles suggests more hemipelagic-dominated sedimentation.

Lithostratigraphic Subunit IA is characterized by very abundant, thick, coarse-grained (sand) layers within fine-grained (clay and silty clay) detrital sediments. The thickness of these layers suggests the depositional environment of tributary channels within the slope basin with mass transport parallel to the first ridge. This facies is unique to Site U1325; it was not cored at any of the other sites. Sedimentation rates are expected to be very high. From the diatom biostratigraphy (see "Biostratigraphy") we have only an estimated sedimentation rate for the upper $129 \mathrm{~m}$ of sediments (Units I, II, and upper part of Unit III) of $43 \mathrm{~cm} / \mathrm{k} . \mathrm{y}$. This is the highest sedimentation rate of all Expedition 311 sites. If we assume that the sedimentation rate for Units II and III is lower than that of Unit I, then the rate for Unit I is probably even higher than $43 \mathrm{~cm} / \mathrm{k} . \mathrm{y}$.

\section{Biostratigraphy}

Cores were recovered from Holes U1325B, U1325C, and U1325D. Hole U1325B contains a $\sim 200 \mathrm{~m}$ thick Quaternary sedimentary sequence, and Hole U1325C contains a $\sim 100 \mathrm{~m}$ thick sedimentary sequence of unknown age with a very thin Quaternary section at the top. The biostratigraphy determined for Site U1325 was based on an examination of all core catcher samples from Holes U1325B and U1325C (Table T2).

\section{Diatoms}

Diatoms are rare to very abundant and poorly to well preserved in Hole U1325B in the interval from $\sim 9$ to $\sim 52$ mbsf, where diatom assemblages are dominated by such marine species as Neodenticula seminae, Stephanopyxis dimorpha, Stephanopyxis spp., Thalassionema nitzschioides, and Thalassiosira spp. and are associated with abundant resting spores of the shallow-marine diatom genus Chaetoceros. In the interval from $\sim 62$ to $\sim 115 \mathrm{mbsf}$, diatoms are very rare and poorly preserved in general, and it is rather difficult to note the predominance of either marine or nonmarine species except for few samples. Diatoms are very rare to abundant and poorly to moderately preserved in the interval from $\sim 129$ to $\sim 198$ mbsf, and the diatom assemblages are dominated by either marine species N. seminae, S. dimorpha, Stephanopyxis spp., T. nitzschioides, and Thalassiosira spp. or by the nonmarine diatom Aulacoseira granulata s.l. The abundances of all these species vary greatly from sample to sample. Abundant resting spores are frequently associated with marine diatoms in this interval as well. Upward-increasing patterns of nonmarine diatoms, which may reflect sedimentary cycles, are recognized in this interval. Diatoms are barren to common and poorly preserved in the interval from $\sim 192$ to 299 mbsf in Hole U1325C, where diatom assemblages are dominated by the nonmarine diatom A. granulata s.l., if present at all.

The interval between the shallowest sample and Sample 311-U1325B-15X-CC (9.34-115.47 mbsf) contains N. seminae but lacks Proboscia curvirostris and was assigned to North Pacific Diatom (NPD) Zone 12 (N. seminae Zone; 0-0.3 Ma). The last occurrence (LO) of $P$. curvirostris was recognized in Sample 311-U1325B-16X-CC (129.49 mbsf), marking the NPD Zone $12 / 11$ boundary (P. curvirostris Zone). The interval between the LO of $P$. curvirostris and Sample 311-U1325C-1X-CC (129.49-192.03 mbsf) contains P. curvirostris, but lacks Actinocyclus oculatus, and was assigned to NPD Zone 11 (P. curvirostris Zone; 0.3-1.0 Ma). The interval between Samples 311-U1325C-2XCC and 15X-CC (199.08-299.12 mbsf) is either barren or contains no biostratigraphic zonal marker diatoms because of possible increased terrestrial input by turbidites. Therefore, no diatom zone and age assignments are possible for this interval. No abrupt changes in lithology or diatom abundance are observed between this interval and the overlying interval, suggesting it might be Pleistocene in age.

\section{Interstitial water geochemistry}

The main objectives at this site were to describe the evolution of the IW chemistry and the distribution of gas hydrate at the first tectonic slope basin, which is presently being deformed and eventually will be incorporated into the Cascadia accretionary prism.

A total of 92 IW samples were processed from two holes cored at Site U1325. In Hole U1325B, 62 whole-round samples, $10-33 \mathrm{~cm}$ in length, were processed. The samples were collected at a frequency of 
two per section in the first core and two to three per core in the remaining XCB cores, except for Core 311-U1325B-9X, which had low recovery. In an effort to characterize the IW chemistry associated with gas hydrate-bearing sediment and compare it with sediment with an IW composition more typical of background conditions, whole-round samples were chosen from intervals with infrared (IR) camera temperature anomalies and from zones with a less anomalous thermal signal within the zone of gas hydrate occurrence. Seven of the samples where the presence of gas hydrate was inferred from IR anomalies were carefully described and imaged prior to the squeezing process, with the goal of establishing a relationship between lithology and gas hydrate occurrence. The maximum IR temperature anomalies were associated with sandy layers ranging from several millimeters to $\sim 3 \mathrm{~cm}$ in length. Sand and clay lithologies were split and squeezed separately. In addition, before starting coring operations in Hole U1325B, a $10.5 \mathrm{~cm}^{3}$ bottom water sample was recovered from $\sim 20 \mathrm{~m}$ above the seafloor using the WSTP tool. The bottom water sample was split for microbiology and geochemistry studies.

In Hole U1325C, 24 whole-round IW samples (20 samples were $10-50 \mathrm{~cm}$ long, one sample was $80 \mathrm{~cm}$ long, and three samples were $134 \mathrm{~cm}$ long) were processed at a sampling frequency of one to two per core depending on recovery. One sample was discarded because it came from a highly disturbed XCB core with no intact "biscuits" present. As in Hole U1325B, some of the whole-round sampling was guided by IR temperature anomalies. Emphasis was also given to obtain at least one representative "background" sample from each core. As seen in Hole U1325B, the IR low-temperature anomalies were primarily associated with sands. In five of the samples, the sand and clay lithologies were split and squeezed separately, except Sample 311-U1325C-4X$1,112-124 \mathrm{~cm}$, where the sand layer was $\sim 9 \mathrm{~cm}$ thick and the clay portion of the sample was too small for squeezing. In addition, we analyzed two samples from Core 311-U1325C-10P, recovered from 256.2 mbsf.

Hole U1325D recovered one APC core with the purpose of establishing the mudline at Site U1325. Four IW samples were collected from this core.

The IW data collected at Site U1325 are listed in Table T3. Also, in Table T4 we list sulfate-corrected data, which represent the composition of the IW corrected for drill-fluid contamination and include data from the bottom water sample collected with the WSTP tool. The sulfate-corrected data for Holes
U1325B and U1325C are illustrated in Figures F23, F24, and F25.

\section{Salinity and chlorinity}

Salinity and chlorinity profiles at this site are characterized by an advective system that transports water with higher than seawater salinity and chlorinity ( 36 and $600 \mathrm{mM}$, respectively) from a deeper source (Fig. F23). The chlorinity of this fluid is $7.3 \%$ above the modern seawater value, a percent increase that is more than twice the value of the interglacial maximum ocean value (3.5\%). Because Site U1325 is located within an isolated basin, it seems unlikely that it is connected to a deep-seated brine source. The elevated solute concentration may instead be caused by low-temperature diagenetic reactions in the deeper parts of the basin. A plausible candidate for such a reaction is the alteration of volcanic ash to clay minerals and/or zeolites. These reactions consume $\mathrm{H}_{2} \mathrm{O}$ and, therefore, increase the in situ salinity and chlorinity values. This inference is supported by the $\mathrm{Ca}$, $\mathrm{Mg}, \mathrm{Sr}, \mathrm{K}$, and $\mathrm{B}$ concentration versus depth profiles discussed below (Figs. F25, F26).

In the zone extending from $\sim 70$ to 240 mbsf (the BSR is at $\sim 230 \mathrm{mbsf}$ ), salinity and chlorinity data show discrete excursions to fresher values. The minimum salinity and chlorinity values recorded are 13 and $286 \mathrm{mM}$ (221 mbsf), respectively; $42 \%$ and 51\% of seawater values and $38 \%$ and $49 \%$ of the background saline fluid values, indicating that gas hydrate was present in the cores and dissociated prior to processing the samples. The salinity and chlorinity anomalies are consistent with observations of distinct negative thermal excursions in IR scans (see "Physical properties"). Indeed, the lower salinity and chlorinity points, shown in Figure F23, represent samples collected to specifically target the more pronounced IR temperature anomalies. Similar to Site U1328, our observations at this site indicate that gas hydrate predominantly occupies the sandy layers.

Two interesting observations are noted in Figure F23 between $\sim 180$ mbsf and the depth of the seismically inferred BSR:

1. No background salinity and chloride concentration data were obtained, as every IW sample and subsample analyzed, including the separated clay samples, is fresher than the advecting high-salinity/chlorinity fluid.

2. The freshest sand samples were recovered from within this subzone.

These observations suggest that in the $50 \mathrm{~m}$ above the BSR depth the average concentration of gas hy- 
drate is higher, and consequently, although sands contain more gas hydrate, some of the gas hydrate is also associated with the clay lithology, either in a disseminated mode or as discrete layers separating the clays.

\section{Biogeochemical processes}

Intense microbial activity at Site U1325 results in sulfate depletion, phosphate and alkalinity production, and significant $\mathrm{Ca}$ and $\mathrm{Mg}$ depletion in the IW of the uppermost $3 \mathrm{~m}$ (Figs. F24, F25). Hydrogen sulfide smell was notable while cleaning the first two whole-round samples $(311-\mathrm{U} 1325 \mathrm{~B}-1 \mathrm{H}-1,65-80 \mathrm{~cm}$, and $1 \mathrm{H}-1,135-150 \mathrm{~cm}$ ).

At this site, the sulfate/methane interface (SMI) was placed between 4 and $5 \mathrm{mbsf}$, based on samples recovered from Hole U1325D (Fig. F27). A comparison between data from Holes U1325B and U1325D shows an offset in the depth of the SMI of $\sim 2.5 \mathrm{~m}$, which suggests that the mudline was missed in Hole U1325B.

In the uppermost lithostratigraphic units at Sites U1329, U1327, and U1328, sedimentation rates are 9.2, 22, and $34.3 \mathrm{~cm} / \mathrm{k} . y$. , respectively (see "Biostratigraphy"). At Site U1325, the sedimentation rate is $\sim 38.3 \mathrm{~cm} / \mathrm{k} . \mathrm{y}$. (see "Biostratigraphy" and "Lithostratigraphy"). Because of the high sedimentation rates, organic matter accumulation rates are likely higher than at the other sites drilled during Expedition 311. This in turn allows for higher organic matter respiration rates, resulting in the highest alkalinity (52.9 $\mathrm{mM}$ at $26.7 \mathrm{mbsf})$, ammonium (16 mM at $297.8 \mathrm{mbsf})$, and phosphate $(121 \mathrm{mM}$ at 26.7 mbsf) concentrations among the Expedition 311 sites (Fig. F24).

The first peak in the $\mathrm{Mg} / \mathrm{Ca}$ ratio (Fig. F25) at $~ 2.2$ mbsf in Hole U1325B shows that this uppermost zone of carbonate precipitation is dominated by the preferential loss of Ca relative to $\mathrm{Mg}$. Ca concentration falls to $\sim 25 \%$ of the original seawater value, and the $\mathrm{Mg} / \mathrm{Ca}$ molar ratio increases to about three times the seawater value. A second zone of intense carbonate diagenesis is indicated by a large maximum in the $\mathrm{Mg} / \mathrm{Ca}$ ratio at $\sim 35 \mathrm{mbsf}$, which corresponds with the approximate depth of the alkalinity maximum and the $\mathrm{Ca}$ minimum (Fig. F25). Between the two $\mathrm{Mg} / \mathrm{Ca}$ maxima, Ca concentration decreases by $<1 \mathrm{mM}$ and $\mathrm{Mg}$ concentration increases by $\sim 5 \mathrm{mM}$. The increase in $\mathrm{Mg}$ concentration coincides with a peak in ammonium values. Despite consumption by carbonate diagenesis, the $\mathrm{Mg}$ concentration and $\mathrm{Mg} /$ $\mathrm{Ca}$ ratio increase, indicating that clays must be the source of the Mg supplied by ion exchange with ammonium. The decline in the $\mathrm{Mg} / \mathrm{Ca}$ ratio below 35 mbsf is most likely being caused by recrystallization of carbonates where $\mathrm{Ca}$ is exchanged in favor of $\mathrm{Mg}$. However, for each $\mathrm{Ca}$ ion released, $3.5 \mathrm{Mg}$ ions are removed from solution, suggesting that $\mathrm{Mg}$ is involved in more than one reaction, most likely in the alteration of volcanic ash into a Mg-rich clay at the depth of the saline fluid formation. Similarly, Ca and Sr concentration versus depth profiles indicate production at greater depth, also consistent with alteration of volcanic material.

From the seafloor to $\sim 200 \mathrm{mbsf}$, silica concentrations range between 400 and $800 \mathrm{mM}$, considerably above the bottom water value of $157 \mathrm{mM}$. These concentration values are controlled by diatom dissolution. Below 200 mbsf, silica concentrations drop to 200$500 \mathrm{mM}$. This change in silica concentrations coincides with the depth where the terrigenous input into the sediment rapidly increases with a concomitant decrease in diatom abundance (see "Biostratigraphy").

\section{Diagenetic deep fluid}

The salinity and concentration profiles of $\mathrm{Cl}, \mathrm{Na}, \mathrm{K}$, and $\mathrm{B}$ provide important information on the nature of the deep-seated advecting fluid at this slope basin site. As indicated in Figures F23, F24, and F26, the fluid has higher than seawater salinity and chlorinity values, is enriched in $\mathrm{Ca}$ and $\mathrm{Sr}$, and depleted in $\mathrm{Mg}$, $\mathrm{K}$, and $\mathrm{B}$. These distributions are consistent with lowtemperature volcanic ash alteration reactions that form $\mathrm{Mg}$ and $\mathrm{K}$ clay minerals and K-zeolites. At this site, the original IW evolves with depth from seawater composition into a $\mathrm{CaCl}$ brine. Extrapolating the slopes of the $\mathrm{Mg}$ and $\mathrm{Ca}$ concentration versus depth profiles indicates that at $\sim 500$ mbsf $\mathrm{Mg}$ concentration should reach zero and $\mathrm{Ca}$ concentration will be above its seawater value.

\section{Organic geochemistry}

The shipboard organic geochemistry program for Site U1325 included analysis of the composition of volatile hydrocarbons $\left(\mathrm{C}_{1}-\mathrm{C}_{5}\right)$ and nonhydrocarbon gases (i.e., $\mathrm{O}_{2}$ and $\mathrm{N}_{2}$ ) from headspace (HS) gas samples, void gas samples, and a gas sample recovered during the PCS degassing experiment. Sediment from IW squeeze cakes was analyzed for content of inorganic carbon (IC) (also expressed as weight percent $\mathrm{CaCO}_{3}$ ), total carbon (TC), and total nitrogen (TN). Total organic carbon (TOC) was calculated as the difference between TC and IC. A total of 78 samples for HS and solid-state analyses were collected at Site U1325. Most of the HS samples were collected on the cut end of core sections facing the IW samples so that the gas and IW data could be integrated. Core 311-U1325B-1H was sampled twice per $1.5 \mathrm{~m}$ 
section to characterize the SMI. It was later determined that this core may have missed the mudline, so an additional hole was drilled to definitively establish the SMI depth (Core 311-U1325D-1H). Three sets of HS samples were collected from inside and outside each IR anomaly interval and imaged with the IR camera to confirm that the samples contained sediment from the cold section of the core.

A total of 45 void gas samples were collected from Site U1325 from depths where gas cracks in the sediment were first observed (9.1 mbsf) to $297.84 \mathrm{mbsf}$. A gas sample was collected from a PCS degassing experiment conducted with Core 311-U1325C-10P (see "Pressure coring").

The primary objectives of the organic geochemistry sampling program at this slope basin were to

- Determine the origin (microbial versus thermogenic) of the gases recovered by HS gas, void gas, and PCS degassing techniques;

- Investigate the relationship between the gas composition and the distribution of gas hydrate in the system; and

- Compare the carbon and nitrogen contents to gas related features in the sediments.

\section{Hydrocarbons}

\section{Headspace gas and void gas compositions}

Hydrocarbon HS gas measurements from Holes U1325B, U1325C, and U1325D are listed in Table T5. Results are reported in parts per million by volume (ppmv) of methane, ethane, ethylene, and propane in the air headspace of a $25.41 \pm 0.18 \mathrm{~mL}$ serum vial and as the millimolar concentration of dissolved methane in the IW (see "Organic geochemistry" in the "Methods" chapter). Methane content increased rapidly from $10 \mathrm{ppmv}$ in the near-surface sample (0.8 mbsf) to $\sim 14,000 \mathrm{ppmv}$ at $7.5 \mathrm{mbsf}$. In the deeper sections of Holes U1325B and U1325C, the methane HS concentrations generally varied between 2000 and 6000 ppmv and showed no relationship with depth (Fig. F28). The two HS samples outside this range $(\sim 11,000$ and 26,000 ppmv) were collected from cold spots identified with the IR camera. Trace amounts of ethane $(<1 \mathrm{ppmv})$ were present in four samples from sediment depths $>248$ mbsf. There was no evidence of ethylene or propane in any HS samples collected from Site U1325. Air samples collected from the catwalk area during Site U1325 operations had an average concentration of $1.84 \pm$ $0.29 \mathrm{ppmv}(n=2)$ methane, which is similar to the current atmospheric methane concentration $(\sim 1.7$ ppmv). The data reported in Table $\mathbf{T} 5$ are uncorrected for the atmospheric contribution.
The composition of gas from voids in the core liner is shown in Table T6 and displayed relative to depth in Figure F29. With the exception of several samples that contained a large percentage of air, the void gas was composed almost entirely of methane with a small percentage of carbon dioxide $(\sim 0.1 \%-1.2 \%)$. Trace quantities of $\mathrm{C}_{2+}$ hydrocarbons $(<13 \mathrm{ppmv})$ were present above the seismically inferred BSR (230 mbsf). With greater depth, the concentrations of ethane, propane, and $i$-butane increased but did not exceed 100 ppmv. Trace concentrations of $\mathrm{C}_{2+}$ hydrocarbons suggest limited contribution of thermogenic gases. Source identification will be verified by postcruise stable carbon isotope analysis of methane.

The molecular ratios of methane to ethane $\left(\mathrm{C}_{1} / \mathrm{C}_{2}\right)$ were the highest observed during Expedition 311. Values from where gas voids were first observed (9.1 mbsf) to the seismically inferred BSR ranged from $\sim 61,000$ to 205,000 and increased slightly with depth (Fig. F30). Below the BSR, the values decrease slightly to a minimum of $\sim 10,000$ at the base of Hole U1325C. This "low" value, however, is among the highest values measured at the other sites investigated during Expedition 311.

The hydrocarbon molecular ratios (e.g., $\mathrm{C}_{1} / \mathrm{C}_{2}$ ) from Site U1325 did not provide clear evidence for gas hydrate in the interval above the seismically inferred BSR, whereas IR temperature anomalies (see "Physical properties") and low chloride anomalies (see "Interstitial water geochemistry") clearly did. It appears that the concentrations of $\mathrm{C}_{2+}$ hydrocarbons in this system were too low to have had a measurable effect on the molecular signature of the gas hydrate. We suspect the gas hydrate identified by the IR and IW data was essentially pure methane hydrate with a molecular composition indistinguishable from the background void gas signature. Postcruise stable carbon isotope analysis of the methane and ethane should help resolve this issue.

Gas composition expressed by the $\mathrm{C}_{1} / \mathrm{C}_{2}$ ratio of $\mathrm{HS}$ and void gas is plotted relative to sediment temperature in Figure F31. The sediment temperature was estimated assuming the calculated geothermal gradient of $60^{\circ} \mathrm{C} / \mathrm{km}$ (see "Physical properties"). The monitoring of $\mathrm{C}_{1} / \mathrm{C}_{2}$ in void and HS samples and its relationship to temperature was developed as a safety guideline by the Joint Oceanographic Institutions for Deep Earth Sampling (JOIDES) Pollution Prevention and Safety Panel during ODP. $\mathrm{C}_{1} / \mathrm{C}_{2}$ ratios are described as either "normal" or "anomalous" depending upon where they plot relative to the slightly diagonal line in Figure F31. All values measured at Site U1325 were within the acceptable "normal" limits for safe drilling (Pimmel and Claypool, 2001). 


\section{Pressure coring system gas composition}

Splits from gas recovered during the Core 311U1325-10P PCS degassing experiment contained as much as $1.5 \%$ ethane. The void gas from above (Core 311-U1325C-9X) and below (Core 11X) this core contained ethane at concentrations of 54 and 67 ppmv. Furthermore, the check samples analyzed in the PCS van did not contain elevated ethane. We concluded that the samples were contaminated during storage and did not reflect the composition of the PCS gas.

\section{Biogeochemical processes}

The IW and HS from Core 311-U1325B-1H were sampled at high depth resolution to define the biogeochemical zones associated with the SMI. The depth of sulfate depletion for Core 311-U1325B-1H was 2.2 mbsf, but it was later determined that this core missed the mudline. Core $311-\mathrm{U} 1325 \mathrm{D}-1 \mathrm{H}$, which was collected near the end of Site U1325 operations specifically to establish the mudline, placed the actual depth of sulfate depletion (by extrapolation) to between 4 and 5 mbsf (see "Interstitial water geochemistry"). The dissolved methane concentration data from Core 311-U1325D-1H were complementary to the sulfate data and established the depth of the SMI at $\sim 1.5 \mathrm{mbsf}$ (Fig. F32). The concentrations of sulfate $(1.1 \mathrm{mM})$ and methane $(0.5$ $\mathrm{mM}$ ) at the SMI should support the net anaerobic oxidation of methane (AOM) (Hoehler et al., 1994). Microbiological and geochemical studies of AOM should utilize the high-resolution samples from Core 311-U1325B-1H and assume an SMI depth of 4-5 mbsf (as determined from Core 311-U1325D-1H) for sulfate and methane flux calculations.

\section{Sediment carbon and nitrogen composition}

The sediment IC, carbonate $\left(\mathrm{CaCO}_{3}\right), \mathrm{TC}$, TOC, and TN concentrations and $\mathrm{C} / \mathrm{N}$ ratios from Site U1325 are listed in Table $\mathbf{T 7}$ and plotted relative to depth in Figure F33. With the exception of the interval from 127.9 to 143.7 mbsf, where IC ranged between 1.0 and $1.4 \mathrm{wt} \%$, IC was relatively low throughout the core and showed no clear trend with depth. The TOC was highest in the surface (0-6 mbsf) sediments (several values exceeded $1.5 \mathrm{wt} \%$ ) and tended to decrease with depth. TN showed no apparent trend with depth. The $\mathrm{C} / \mathrm{N}$ ratios averaged $\sim 8$ in the uppermost 100 to $150 \mathrm{~m}$ at Site U1325, which is consistent with a primary origin of marine organic matter. Below $150 \mathrm{mbsf}$, the $\mathrm{C} / \mathrm{N}$ ratios averaged 5.5. This value is more enriched with nitrogen than expected for marine organic matter ( 6-7). Ion exchange of ammonium for magnesium on clays (see "Intersti- tial water geochemistry") may explain the low $\mathrm{C} / \mathrm{N}$ ratios.

\section{Microbiology}

Site U1325 is located along the main transect of sites established during Expedition 311 across the northern Cascadia accretionary prism within a small basin on the lower slope between two accretionary ridges. It was the fourth site sampled for microbiology. We anticipated a shallow sulfate/methane interface and a gas hydrate stability zone (GHSZ) that extended to 230 mbsf. Efforts continued to obtain live anaerobic methane oxidizers, potentially unknown gas hydrate-associated microbial communities, high-pressure adapted microorganisms, and methanogens. Subsamples for direct cell counts and biological contamination tests continued at this site.

\section{Microbiological sampling}

Sampling from the mudline (Sample 311-U1325B1H-1, 0-3.0 cm) in Hole U1325B and the deepest core (Sample 311-U1325C-15X-2, 5-15 cm; 296.14 mbsf) in Hole U1325C targeted microorganisms for aerobic and anaerobic high-pressure culturing. The SMI in the upper sedimentary section of Hole U1325B was targeted for intensive, coupled microbiological and geochemical sampling. At this site, the SMI was placed between 4 and 5 mbsf (see "Interstitial water geochemistry" and "Organic geochemistry"). Coring resumed in Hole U1325C where coring in Hole U1325B ended (188 mbsf) and completed the targeted sediment section.

Methanogenesis can occur in most anaerobic environments, but it becomes the major metabolic strategy when other electron donors such as nitrate, $\mathrm{Fe}(\mathrm{III})$, and sulfate are depleted. We sampled regularly downhole to below the depth of the predicted BSR to quantify methanogenesis in these sediments (see "Microbiology" in the "Methods" chapter).

\section{Contamination tests}

\section{Perfluorocarbon tracers}

Samples for perfluorocarbon tracer (PFT) and microsphere analyses were taken immediately from the ends of whole-round cut sections on the catwalk. Because the freshly cut sediment surface was potentially contaminated by PFT smeared along the core liner, the sediment surface at the sampling spots was scraped away using a clean spatula before sampling with a syringe. Subsamples $\left(\sim 5 \mathrm{~cm}^{3}\right)$ were taken from outer and inner layers from each core for gas chromatograph analysis as described in "Microbiology" in the "Methods" chapter. Samples were analyzed as 
described and raw data are presented in Table T8. We also measured the air on the catwalk to confirm background PFT levels. The results (Table T8) show that the interior portions of the APC cores from Hole U1325B are less contaminated with PFT than the exterior portions.

\section{Fluorescent microspheres}

Comparisons of fluorescent microsphere penetration in paired samples collected from the edge and center of the cores are summarized in Table T8. Microscopic analysis of the outer portion of the APC cores showed detectable numbers of $10^{4}$ microspheres/g of sediment, whereas microspheres were generally below the detection limit of 100 microspheres/g in samples taken from core interiors. Sediment samples from XCB cores were collected from the split cores to allow separate sampling of specific structures (e.g., sand layers, biscuits, and drilling slurry).

\section{Shipboard analysis}

We started an enrichment culture experiment for methanogens with a few sediment samples (see "Enrichment cultures" in the "Methods" chapter). Samples 311-U1325B-10X-5, 52-67 cm (78.8 mbsf) and 311-U1325C-4X-1, 55-70 cm (208.00 mbsf), and 8X$3,97-112 \mathrm{~cm}$ (239.15 mbsf, from approximately the BSR depth) were used for this enrichment culture study.

Samples were taken from the top (Sample 311U1325B-1H-1, 0-3 cm) and the bottom (Sample 311U1325C-15X-2, 5-15 cm; $296.14 \mathrm{mbsf}$ ) of the sedimentary section for inoculation of enrichment cultures targeting high pressure-adapted heterotrophic and sulfate-reducing microorganisms. Samples were maintained at low temperature, and dilution series were inoculated to culture for microorganisms at $55.1 \mathrm{MPa}$ and $4^{\circ} \mathrm{C}$. Cultures for sulfate reducers required preparation in the anaerobic chamber and were fed formate, acetate, or lactate as a carbon source.

\section{Physical properties}

Site U1325 is located in a small basin on the lower slope between the first and second accretionary ridges and provides a contrast to the accretionary ridges sampled at Sites U1326 and U1327.

Physical properties were measured in cores recovered from Holes U1325B and U1325C. Hole U1325B extended to $210 \mathrm{mbsf}$, where it was abandoned because of a stuck PCS tool. Coring in Hole U1325C began at 188 mbsf and continued to $\sim 305$ mbsf. Figure F34 presents an overview of the physical property data obtained for these holes. All cores from this site were systematically scanned upon arrival on the catwalk to detect IR anomalies indicative of gas hydrate dissociation during core recovery. Cold temperature anomalies were observed at a wide range of depths from $\sim 70$ to $250 \mathrm{mbsf}$, and catwalk sampling was conducted based on these scans. A total of 86 IW samples were taken based on the IR images to extend the chlorinity anomaly database available for calibrating IR data as a proxy for gas hydrate saturation. In the following sections we discuss these data and compare them to data acquired at other sites.

\section{Infrared images}

All cores were scanned on the catwalk following the track-mounted IR camera procedures described in "Physical properties" in the "Methods" chapter. Portable Document Format images of the scans of all cores are available in "Site U1325 core descriptions." Temperature arrays in comma-separated value file format were exported from the IR camera software and concatenated for each core. The arrays were then further concatenated for all cores available in a given hole. Figure F35 shows cold thermal anomalies in the concatenated false-color IR images for Holes U1325B and U1325C. The Hole U1325A LWD/MWD resistivity images and pore water saturation derived from these data are shown on the left for comparison. Core recovery and core handling times (i.e., the time from the "core on deck" call to IR imaging) are shown on the right. Core recovery decreased and coring time increased in zones where large amounts of gas hydrate are indicated.

Although the upper two cores at this site were cold $\left(7^{\circ}-8^{\circ} \mathrm{C}\right)$, this was likely caused by their low in situ temperature $\left(3^{\circ}-4^{\circ} \mathrm{C}\right)$, which was a result of the cold bottom water temperature at this depth $\left(\sim 1.9^{\circ} \mathrm{C}\right)$. The bottom water temperature is lower than the seafloor intercept calculated from linear regression of subsurface temperatures (see "In situ temperature profile"), suggesting a relatively recent change in bottom water temperature. The first gas hydraterelated IR anomaly occurred at $\sim 70$ mbsf and was confirmed by a low-chlorinity anomaly. Anomalies continued to be observed sporadically to $\sim 250 \mathrm{mbsf}$, with a cluster of IR anomalies at $\sim 140-160$ mbsf. Coverage from 80 to 230 mbsf was adversely affected by poor recovery (Fig. F35) and one instance of IR track failure (Core 311-U1325C-24X). We note that the maximum depth of observed IR anomalies is deeper than the anticipated BSR depth of 230 mbsf. Gas hydrate was present to at least $250 \mathrm{mbsf}$, as inferred from low-chlorinity anomalies in IW samples chosen on the basis of IR anomalies. This deeper 
depth for the base of the GHSZ is compatible with downhole temperature measurements.

As a precursor to quantitative studies of the temperature anomalies, downhole temperatures were averaged for each pixel row in the IR temperature array, excluding pixels $\sim 1 \mathrm{~cm}$ from the edge of the image and $2 \mathrm{~cm}$ along the midline of the image to eliminate major thermal artifacts in the images. Figure F36A shows the complete temperature profile in this hole. Figure F36B and F36C provides a detailed look at one particular temperature anomaly at $209.5 \mathrm{mbsf}$ with a $\Delta T$ of $-2.5^{\circ} \mathrm{C}$. This anomaly corresponds very closely to a high-resistivity anomaly in the Hole U1325A LWD resistivity data (Fig. F36D). Figure F37 shows a sample that was taken based on a similar IR anomaly. A coincident photograph and IR image of the sample are shown as well as a temperature profile through the anomaly. This anomaly was associated with a $\sim 3 \mathrm{~cm}$ thick dipping sand-rich layer.

\section{Sediment density and porosity}

Gamma ray attenuation (GRA) densities were measured on the multisensor track (MST), and bulk density, grain density, and porosity were calculated from the measured wet and dry weights and dry volume of the sediments (moisture and density [MAD] measurements; Table T9). Both estimates of density are compared to in situ densities measured by the LWD/ MWD tools (Fig. F34). The MAD data from 55 to 85 mbsf are compared to LWD/MWD data and to contact resistivity, magnetic susceptibility, and thermal conductivity in Figure F38. The different data sets show coincident decreases in density, resistivity, magnetic susceptibility, and thermal conductivity and an increase in porosity that corresponds to Core 311-U1325B-10X, where sand layers are conspicuously absent compared to the overlying sediments. The first IR anomaly occurs near the boundary between this clay-rich interval and the overlying sandrich sediments. This IR anomaly is coincident with a low-chlorinity IW analysis.

Figure F39 shows a comparison between the data at this site and at other sites drilled during Expedition 311. It shows the increasing amount of sand, indicated by low porosity "outliers," toward the outer part of the accretionary complex. It also shows that the sediments cored at Sites U1328 and U1329 have generally higher porosity than sediments at Sites U1327 and U1325, especially at depths $>150$ mbsf. The difference between Sites U1327 and U1328 is consistent with differences in the velocity structure at these sites, as indicated by VSP results.

\section{Magnetic susceptibility}

Magnetic susceptibility at this site was generally high and variable, similar to that observed at Site U1328. Causes for the intersite variability in magnetic susceptibility will be a topic for postcruise research. The variability is likely related to changes in the abundance of silty and sandy turbidites, reflecting different sedimentary environments. The spatial correlation between low magnetic susceptibility and a highporosity, clay-rich layer was discussed above. This contrasts with the correlation between a moderateporosity, very stiff clay-rich interval and the low magnetic susceptibility observed at Site U1327.

\section{Compressional wave velocity from the multisensor track and Hamilton frame}

Velocity measurements using both the MST and the Hamilton frame were made only on the single core from Hole U1325D. Velocity measurements were obtained from 0.1 to $4.2 \mathrm{mbsf}$ and ranged from 1465 to $1530 \mathrm{~m} / \mathrm{s}$. The MST produced results that were consistently lower than the results from the Hamilton frame. The Hamilton frame results generally had a greater scatter than the results from the MST; however, both data sets follow the same trend. Velocity tends to decrease with depth (Fig. F40), contrary to typical observations. Ordinarily, velocity increases with depth in near-seafloor sediments. Velocity also appears to decrease with increasing density (Tables T9, T10). Again, this contrasts with typical data trends, and we have no obvious explanation for these observations.

\section{Shear strength}

Shear strength measurements were made throughout Holes U1325B and U1325C using both the handheld Torvane and the automated vane shear (AVS) system to compare the two techniques over a broad range of shear strengths (Tables T11, T12). Measurements were made on the working half of the split core after resistivity and velocity measurements had been completed (for the AVS) and before or after MAD samples had been taken (for the Torvane). Measurements were taken in areas of the core where the sediment was minimally disturbed and as close to the location of MAD samples as possible. At least two Torvane shear strength measurements were taken per section and often more where there were visual changes in the sediment (i.e., color and grain size).

Shear strength measurements obtained with the AVS are similar to those obtained with the handheld Torvane (Fig. F41A). Shear strength values generally increase with depth and range from $5 \mathrm{kPa}$ at the top of 
the hole to $205 \mathrm{kPa}$ at the bottom. The ratio of shear strength to overburden pressure is a measure of the consolidation state of the sediments (Fig. F41C). A ratio $>0.25$ indicates overconsolidation and a ratio $<0.25$ indicates underconsolidation (e.g., Riedel et al., 2006). Except for the uppermost $5 \mathrm{~m}$ of the hole, the sediments are underconsolidated. Overconsolidation at the top of the hole may be caused by erosion or high carbonate content in this area.

\section{Electrical resistivity}

Electrical resistivity was measured on core samples by both contact and noncontact methods. The contact resistivity measurement interval varied depending on the quality of the core. Noncontact resistivity (NCR) measurements were made using the MST at $2.5 \mathrm{~cm}$ intervals on all cores. The values obtained from the NCR sensor were scattered because of gas expansion cracks in the cores. Contact resistivity measurements were made to $260 \mathrm{mbsf}$ and range from 0.3 to $3.0 \Omega \mathrm{m}$ (Fig. F42A; Table T13). Higher resistivities were recorded, but these are almost certainly caused by cracks in the sediment or roughness of the split core surface, which occurs in stiff sediments. Resistivity generally increases with depth and becomes more scattered; however, there are areas where there is a marked decrease in resistivity with depth (i.e., at 60-70 mbsf).

Pore water resistivities were calculated from IW salinities using equations developed by Fofonoff (1985) and corrected to $20^{\circ} \mathrm{C}$ (Fig. F42A). These were used to calculate the formation factor (ratio of saturated sediment resistivity to pore fluid resistivity) of the contact resistivities (Fig. F42B). Archie's parameters were then determined by fitting Archie's equation to the formation factor and MAD porosity data. At this site, sands and clays were separated based on notes made when samples were taken for MAD analysis. Distinctly different Archie's parameters were obtained in the two cases (Fig. F42D). Porosities obtained using Archie's equation for clays were compared to MAD porosities (Fig. F42C); both techniques produced similar values and trends.

\section{Thermal conductivity}

Thermal conductivity was measured on whole-round cores after completion of the MST measurements. Thermal conductivity values ranged from 0.6 to 1.3 $\mathrm{W} /(\mathrm{m} \cdot \mathrm{K})$ (Table T14; Fig. F34). Low thermal conductivities below 100 mbsf may be caused by the presence of gas expansion cracks. Above 100 mbsf, thermal conductivies $>1.1 \mathrm{~W} /(\mathrm{m} \cdot \mathrm{K})$ were consistently obtained in sand-rich zones; lower thermal conductivities appear to be associated with clay-rich zones. This apparent correlation with lithology will be fur- ther investigated postcruise by identifying the measurement points on core photos to better evaluate the impact of core disturbance on the measurements. Because thermal conductivity is measured on whole-round cores, determination of sediment type for each thermal conductivity measurement cannot be assigned at the time the measurement is made. The highest thermal conductivity values generally follow the regional trend defined by Davis et al. (1990). For determination of in situ temperature and heat flow, a constant thermal conductivity value of $1.1 \mathrm{~W} /(\mathrm{m} \cdot \mathrm{K})$ was assumed.

\section{In situ temperature profile}

Six deployments of temperature tools were attempted at Site U1325, and all deployments provided useable data (Table T15; Fig. F43). The three APCT-3 tool deployments in Hole U1325B occurred during times of relatively low heave and yielded excellent quality data. Although heave increased during coring of Hole U1325C and the deployment at 218.6 mbsf was clearly affected, enough time elapsed that the data could be reliably extrapolated to obtain an estimate of in situ temperature. It should be noted, however, that the DVTP recorded unusually high temperatures on the upper thermistor (black line in Fig. F43B). We suspect that the probe rubbed against an asperity in the hole near the upper thermistor. Low temperatures recorded on the upper thermistor at $275.4 \mathrm{mbsf}$ suggest incomplete insertion of the probe into the very stiff sediments near the bottom of Hole U1325C.

Temperatures extrapolated from the data are plotted on Figure F44. The size of the symbols corresponds to data uncertainties of $\pm 0.35^{\circ} \mathrm{C}$ and $\pm 2.5 \mathrm{~m}$, generous estimates for these high-quality, well-calibrated data. A linear fit to the points indicates a thermal gradient of $0.060^{\circ} \pm 0.003^{\circ} \mathrm{C} / \mathrm{m}$ and a seafloor intercept of $3.03^{\circ} \pm 0.55^{\circ} \mathrm{C}$. This is similar to the thermal gradient observed at Sites U1327 and U1328 and lower than the regional gradient expected at this distance from the deformation front. The results are consistent with perturbation of the geothermal gradient because of rapid sedimentation and upward fluid advection (Hyndman and Davis, 1992) and should help to better constrain models for these processes.

The temperature data indicate that the base of the GHSZ for hydrostatic pressure and seawater salinity is at $275 \pm 25$ mbsf. This is considerably deeper than the depth to the BSR of 230 mbsf determined by assuming an average velocity of $1636 \mathrm{~m} / \mathrm{s}$ for sediments above the BSR, which is located $0.282 \mathrm{~s}$ TWT beneath the seafloor. Several explanations can be considered for this apparent discrepancy. The appar- 
ent mismatch may be because of uncertainty in the seismic velocity; an average $P$-wave velocity of 1920 $\mathrm{m} / \mathrm{s}$ would place the BSR at $270 \mathrm{mbsf}$ but appears unreasonably high. Alternative explanations that have been proposed to explain mismatches observed elsewhere between the seismically determined BSR depth and the depth predicted by in situ temperature measurements include inhibition of gas hydrate formation in clay-rich sediments and disequilibrium caused by climate change (e.g., Ruppel, 2000). A GHSZ limit of 275 mbsf at Site U1325 is consistent with the occurrence of IR anomalies at this site, assuming Structure I gas hydrate, which are observed to at least $245 \mathrm{mbsf}$ (with possible candidates to 265 mbsf) at this site.

\section{Paleomagnetism}

Note: This section was contributed by Jennifer Henderson and Katerina Petronotis (Integrated Ocean Drilling Program, Texas A\&M University, 1000 Discovery Drive, College Station TX 77845, USA).

Alternating-field (AF) demagnetization of the sedimentary archive-half sections was used to determine the remanent magnetization components recorded in the recovered cores (Fig. F45). The paleomagnetic data will be used postcruise to characterize the magnetic properties of the sediments and to construct a magnetostratigraphy of the sedimentary section recovered at Site U1325. The AF demagnetization applied at 10 and $20 \mathrm{mT}$ should have removed most of the drill string magnetic overprint, but postcruise demagnetization at higher fields will most likely be required.

Questionable data may be associated with remanence measurements over intervals disturbed or deformed by coring. Similarly, magnetic edge effects, which can be large when measurements are within $\sim 5 \mathrm{~cm}$ of the edge of a section or void, can give biased results. To avoid interpreting results in these regions, we manually noted the disturbed intervals and voids in the cores. Data from these intervals will be removed prior to postcruise interpretation.

\section{Pressure coring}

The main objectives of pressure coring during Expedition 311 were to quantify natural gas composition and concentration in sediments and to determine the nature and distribution of gas hydrate and free gas within the sediment matrix. To achieve these objectives, we

- Measured the quantity and composition of gases released during controlled degassing experiments,
- Conducted nondestructive measurements (X-ray imaging, $P$-wave velocity, and gamma ray density) at in situ pressure and during degassing, and

- Preserved gas hydrate-bearing sediments at in situ pressure for more comprehensive shore-based investigations.

The nondestructive measurements not only provide a direct indication of the existence of gas hydrate, but the resulting data (acoustic impedance) can be used to help interpret regional seismic data. At Site U1325, drilled at the first slope basin, the BSR is a relatively weak reflector with an estimated depth of 230 mbsf. LWD data from Hole U1325A showed alternating high and low resistivities from 122 to 260 mbsf (logging Unit 2; see "Logging units") that are especially well defined from 190 to 220 mbsf. Specific objectives at Site U1325 were to confirm and quantify the presence of gas hydrate above the BSR, with special attention to the layers of alternating resistivities and the occurrence of free gas below the BSR.

\section{Operation of pressure coring systems}

Pressure coring tools were deployed seven times at Site U1325 (Table T16). Two PCS cores, two HRC cores, and one FPC core were taken in Hole U1325B, including two cores within the layer of alternating high and low resistivities at 190-220 mbsf. In Hole $\mathrm{U} 1325 \mathrm{C}$, an FPC core was deployed within the alternating resistivity zone, and a PCS core was recovered from well below the estimated depth of the BSR. Figures F46 and F47 show the pressure and temperature history of the cores during deployment, coring, recovery, and chilling in the ice shuck. Only the pressure cores from Hole U1325C were retrieved under pressure, and only the deepest (Core 311-U1325C10P) contained sediment under pressure.

Pressure coring was extremely difficult at Site U1325. The PCS became stuck in the BHA during the deployment that recovered Core 311-U1325B-28P because the PCS outer core barrel had deformed, possibly as a result of loss of circulation, and a pipe trip was required to free the tool. The HRC deployments both failed because of incomplete penetration, which resulted in collapsed/deformed liners that prevented the lower flapper valve from operating correctly. The FPC deployment that returned an autoclave under near-in situ pressure had an inverted core catcher, which indicated that the stiffness of the sediments was very high and probably exceeded the capabilities of this tool. These problems resulted from attempting to recover pressure cores in sandy lithologies in which even the XCB system had recovery problems. 


\section{Degassing experiments}

At Site U1325, Core 311-U1325C-10P, which was the only core recovered successfully under pressure, was investigated by controlled shipboard degassing experiments (Table T17). This core was taken at 256.1 mbsf, which is $\sim 25 \mathrm{~m}$ deeper than the estimated depth of the BSR.

The degassing experiment included the following steps. First, the volume and density of sediment inside the inner core barrel of the PCS was monitored by X-ray analysis. Next, the PCS was slowly degassed in a temperature-controlled van $\left(7^{\circ} \mathrm{C}\right)$, and the volume and composition of released gas and water, the pressure inside the core, and the ambient air pressure and temperature were monitored (Table T18) as described in "Pressure coring" in the "Methods" chapter. During the degassing procedure, the vertical density distribution in the PCS core was repeatedly determined by GRA scans to examine the evolution of gas voids within the sediment. After degassing was completed, we X-rayed the PCS core again, collected the water remaining in the outer core barrel for mass balance considerations, curated the sediment that was extruded from the core, and subsampled it for IW chemistry, dissolved gases, and physical property analyses.

Degassing of Core 311-U1325C-10P yielded 3.4 L of gas. The composition of the released gas did not change significantly in the course of degassing. Methane was the major gas component, accounting on average for $89.0 \% \pm 3 \%$ of the emitted gas (Table T18). Nitrogen was the second most abundant gas, contributing $8.6 \% \pm 3 \%$ to the gas released. Carbon dioxide, ethane, and higher hydrocarbon concentrations were below the detection limit of the Agilent gas chromatograph used for continuous gas analysis during the degassing experiment. Mass balance calculations yielded a pore space methane concentration of $175 \mathrm{mM}$, indicating $<0.3 \%$ of free gas in the pore space (Tables T18, T19; Fig. F48). The pressure inside the PCS core dropped below the predicted gas hydrate stability conditions when the port valve of the PCS was first opened and water expanded from the outer core barrel into the manifold system. Therefore, no pressure plateaus or rebounds from dissociation of gas hydrate could be expected and a steady decrease of core pressure versus removed gas volume was observed (Fig. F49).

$\mathrm{X}$-ray images and density profiles showed limited gas evolution during depressurization (Fig. F50). A lowdensity zone from 5 to $15 \mathrm{~cm}$ core depth seen in the $\mathrm{X}$-ray scan taken before degassing remained in the Xray scan taken after degassing, probably indicating an interval of disturbed core.

\section{Gas hydrate concentration, nature, and distribution}

Mass balance calculations were only performed for Core 311-U1325C-10P, which may have contained a very small amount of gas hydrate $(0.4 \%)$ or free gas (0.3\%) (Table T20; Fig. F48), depending on the placement of the base of gas hydrate stability. This core was located below the estimated depth of the BSR (230 mbsf), but possibly above the base of the GHSZ (see "In situ temperature profile") and at the base of the zone of alternating high and low resistivities, where core recovery increased. The quantity of excess methane was too small to determine the phase (gas hydrate or free gas) from the nondestructive measurements available for PCS cores (X-rays and gamma ray density).

\section{Downhole logging Logging while drilling}

\section{Operations}

Hole U1325A was spudded at 2212 mbrf (drillers depth) at $2315 \mathrm{~h}$ on 20 September 2005. LWD tools included the GeoVISION resistivity tool, the EcoScope tool, the SonicVISION tool, the TeleScope MWD tool, the ProVision nuclear magnetic resonance (NMR) tool, and the ADNVISION tool. For details on each tool and the measurements it takes, see "Downhole logging" in the "Methods" chapter.

Hole U1325A was the first hole drilled during Expedition 311, and to ensure that the LWD tools were powered up to provide real-time data for gas monitoring, it was decided to drill from the beginning with the pumping rate at a relatively high value of $280 \mathrm{gpm}$. Although it was recognized that such a high pumping rate was likely to wash out the hole near the seafloor, obtaining all the data needed for gas monitoring from the very start received higher priority in this first hole. The first $10 \mathrm{~m}$ of Hole U1325A was drilled with a rotation rate of $10 \mathrm{rpm}$ and an ROP of $10-15 \mathrm{~m} / \mathrm{h}$. We then increased the rotation rate to $40 \mathrm{rpm}$ while keeping other parameters unchanged until 30 mbsf and then increased this rate again to $60 \mathrm{rpm}$, keeping the instantaneous ROP below $60 \mathrm{~m} / \mathrm{h}$ with depth. The target depth of 350 mbsf (2562 mbrf) was reached at $1930 \mathrm{~h}$ on 21 September. The LWD tool string was then brought back to the surface, and rig down and data download were completed by $0600 \mathrm{~h}$ on 22 September.

\section{Gas monitoring with real-time logging-while- drilling/measurement-while-drilling data}

The LWD/MWD logs were acquired to plan coring and pressure coring operations in subsequent holes 
at Site U1325. As Hole U1325A was drilled without coring, the LWD/MWD data had to be monitored for safety to detect gas entering the borehole. As explained in "Downhole logging" in the "Methods" chapter, the primary measurement used for gas monitoring was annular pressure while drilling, which is measured by the EcoScope tool in the borehole annulus. We looked for sudden decreases of $>100$ psi in the annular pressure, which could be caused by lowdensity gas entering the borehole. We also monitored pressure increases of the same magnitude, which could be the result of fluid acceleration caused by a gas kick (Aldred et al., 1998).

Figure F51 shows the measured borehole fluid pressure profile in Hole U1325A after subtraction of the best-fit linear trend. The borehole fluid pressure shows only small fluctuations over the trend, except for a few positive pressure anomalies (20 psi or less) centered at 252, 277, 289, and 297 mbsf. These increases in the drilling fluid pressure coincide with major hole enlargements ( $>13$ inches or $33 \mathrm{~cm}$ ) as seen on the ultrasonic caliper log (Fig. F51). The caliper log also shows a sharp decrease in hole diameter below each washout (to $<9.5$ inches or $24 \mathrm{~cm}$ ), suggesting that the washouts were generated above resistant intervals that were hard to drill. The observed increase in drilling fluid pressure was probably the result of an increase in pumping rates during drilling or to restriction of flow in the annulus by cuttings. The fluid pressure anomalies observed were well below the 100 psi level that would have required preventive action.

We also monitored the coherence of the sonic waveforms acquired by the SonicVISION tool, focusing on the velocity of fluid in the borehole. Loss of coherence in the waveforms and a slower velocity for the drilling fluid indicate the presence of gas. The sonic waveform coherence image in Figure F51 shows a well-defined fluid arrival with a slowness of $\sim 200$ $\mathrm{ms} / \mathrm{ft}$ almost everywhere, which corresponds to the expected fluid velocity of $\sim 1500 \mathrm{~m} / \mathrm{s}$. The only anomaly is a thin interval at 209-210 mbsf, where the fluid arrival suddenly disappears. This interval coincides with a 10 psi negative anomaly in the fluid pressure, suggesting that a small amount of gas may have entered the drilling fluid. Even if the low coherence of the drilling fluid arrival was caused by free gas, it is important to stress that the fluid pressure anomalies were small, and that if gas was in the drilling fluid at depths around $210 \mathrm{mbsf}$, it had to be in low concentrations.

\section{Logging quality}

Figure F51 also shows the quality control logs for Hole U1325A. The ROP was generally $60 \mathrm{~m} / \mathrm{h}$ or less in the interval from the seafloor to TD. This is sufficient to record one measurement every $4 \mathrm{~cm}(\sim 25$ measurements per meter) in the GeoVISION resistivity, and no significant resolution loss was observed with variation in the ROP. The ultrasonic caliper log, which is a direct measurement of the borehole diameter recorded by the EcoScope tool, is our best indicator of borehole size. Because of the relatively high pumping rate, the hole is enlarged near the seafloor, with a diameter as large as 13 inches $(33 \mathrm{~cm})$. The hole diameter then decreases with depth to a value slightly larger than 10 inches $(25 \mathrm{~cm})$. Large washouts and hole restrictions in the interval 255-305 mbsf were noted earlier. The interval 170-235 mbsf also shows many small-scale hole irregularities with the hole diameter up to $\sim 12$ inches $(31 \mathrm{~cm})$. We will show later that the interval 170-235 mbsf contains a number of thin, alternating, high- and low-resistivity layers, where the high-resistivity layers are likely to have high gas hydrate concentrations. The smallscale hole enlargements may take place in unconsolidated, gas hydrate-rich sand layers that fail during drilling.

The density correction, calculated from the difference between the short- and long-spaced density measurements, generally varies from 0 to $0.2 \mathrm{~g} / \mathrm{cm}^{3}$ despite the hole irregularities (Fig. F51), showing the good quality of the density measurements. Figure F52 is a summary of the main LWD logs in Hole U1325A with MAD density and porosity measurements from cores from Holes U1325B and U1325C superimposed (see "Physical properties").

The depth relative to the seafloor was fixed for all LWD logs by identifying the step change in the gamma ray log associated with the seafloor. For Hole U1325A, the gamma ray logging pick for the seafloor was at a depth of 2203 mbrf, $\sim 9 \mathrm{~m}$ above the initial depth estimated by the drillers.

\section{Operations}

\section{Wireline logging}

Hole U1325C was continuously cored to a depth of $300 \mathrm{mbsf}$, which was reached at $0715 \mathrm{~h}$ on 22 October 2005. As the ship's heave remained above $5 \mathrm{~m}$, which exceeds the current wireline heave compensator limits, we decided to try the experimental Schlumberger heave compensator, which feeds heave information back to the winch and, in principle, has no limit on the amount of heave for which it can compensate. The Schlumberger heave compensation system had been successfully tested in two previous short repeat runs at Sites U1327 and U1328, but lacking an extended test we planned two logging runs with tools that had no protruding arms (i.e., calipers). 
Wireline logging operations in Hole U1325C began with the deployment of an armless tool string consisting of the HNGS and the DIT. For details on the different tools, see "Downhole logging" in the "Methods" chapter. After hole preparation, the rig up of the tool string started at $1115 \mathrm{~h}$ and was completed at $1230 \mathrm{~h}$ on 22 October. Despite repeated attempts, we were not able to lower the tool string below a depth of 2465 mbrf (260 mbsf), where the LWD caliper log in Hole U1325A showed a borehole restriction. At $1515 \mathrm{~h}$ we decided to $\log$ up from this depth, and reached the seafloor at $1705 \mathrm{~h}$, after some delay caused by problems reentering the drill pipe. The tool string was back on the rig floor at $1810 \mathrm{~h}$.

At $1835 \mathrm{~h}$ we started rigging up the tool string for the second wireline run in Hole U1325C. This armless string consisted of the SGT, the DSI, and the Lamont-Doherty Earth Observatory (LDEO) high-resolution TAP tool. Rig up was complete at $2000 \mathrm{~h}$. Again, it was impossible to lower the tool string past a hole restriction, this time located at $2391 \mathrm{mbrf}$ (186 mbsf). At $2154 \mathrm{~h}$, we started logging up, while the ship's heave reached $7 \mathrm{~m}$. We completed a first pass at $2295 \mathrm{mbrf}$ (90 mbsf), and lowered the tool for a second pass that we hoped to start at a deeper location than the first pass. The tool string, however, could not go deeper than $2388 \mathrm{mbrf}$ (183 mbsf), and at $2241 \mathrm{~h}$ we started logging up for our second pass. The second pass was completed successfully, the tool string was brought back to the rig floor, and rig down was completed by $0130 \mathrm{~h}$ on 23 October.

Because we did not run a caliper log in Hole U1325C, we cannot clearly determine the effects of hole diameter on the wireline log measurements. The gamma ray $\log$ needs to be corrected for hole size, and the absence of a caliper log prevented us from applying this correction. This results in gamma ray values that are lower than the formation values, which could be the case for most of the section below 140 mbsf. There are a few intervals (e.g., 93-98 and 166-168 mbsf) where the gamma ray and the spherically focused and induction resistivities have very low values, which are likely caused by an enlarged hole (Fig. F53). The LWD/MWD ultrasonic caliper shows some hole irregularities near these intervals (Fig. F51). Apart from these possibly anomalous intervals, the gamma ray and induction logs are of good quality.

A comparison of the gamma ray logs measured by the HNGS tool in the first run and by the SGT tool in the second run shows an excellent correlation (Fig. F53), after some minor depth shifting of the data that is customarily needed to match different wireline runs. This result shows that the Schlumberger heave compensation system performed well when the ship's heave was as much as $7 \mathrm{~m}$.
The acoustic data measured in Hole U1325C appear to be of good quality. The results of two passes are shown in Figure F53, and the acoustic waveforms and slowness-time coherence projections are shown in Figure F54. The velocity profiles acquired in the two passes are very similar, and almost no additional processing was required to derive reliable compressional $\left(V_{\mathrm{p}}\right)$ and shear $\left(V_{\mathrm{s}}\right)$ wave velocities. The poor quality of the lower dipole waveforms below 140 mbsf, however, suggests that they were affected by borehole size.

The depth relative to the seafloor for all wireline logs was fixed by identifying the step change in the gamma ray $\log$ associated with the seafloor. The gamma ray pick for the seafloor was at 2205 mbrf in Hole U1325C.

\section{Logging-while-drilling and wireline logging comparison}

Figure F55 shows a comparison of LWD (Hole U1325A) and wireline (Hole U1325C) data, using the gamma ray and resistivity logs. The LWD and wireline gamma ray logs have similar character and curve shapes, and correlate closely in the interval 70-145 mbsf. On the other hand, the LWD log gives higher readings (100 gAPI on average) than the wireline log (40 gAPI on average). The reasons for this discrepancy have not been fully determined, but it was recognized that the wireline measurements were consistent with values recorded during ODP Leg 146.

The comparison of resistivities shows a close match between the LWD and wireline logs. There are a few exceptions where the wireline logs measure resistivities that are less than those of the LWD logs, notably at 93-95 and 166-168 mbsf. As noted earlier, these low resistivities correspond to anomalously low gamma ray measurements in Hole U1325C, and are probably related to hole enlargements. The similarity between the LWD logs measured in Hole U1325A and the wireline logs measured in Hole U1325C points to high horizontal continuity at Site U1325 compared to the substantial lateral variability noted at Site U1327. The reason for this difference is that much of the interval drilled at Site U1327 was in deformed sediments of the Cascadia accretionary complex, whereas Site U1325 is located in a slope basin whose sedimentary sequence is laterally continuous. Although there is evidence for tilting of the sedimentary sequence in the seismic reflection data, Holes U1325A and U1325C were drilled along the structural strike and therefore should correlate well. Indeed, there is a remarkably close fit between LWD/ MWD formation density from Hole U1325A and density measurements made in core samples from Holes U1325B and U1325C (Fig. F52). 


\section{Logging units}

The logged section in Holes U1325A and U1325C can be divided into three logging units, based on obvious changes in the LWD/MWD and wireline gamma ray, density, electrical resistivity, and acoustic measurements (Figs. F52, F53, F54). The boundary between logging Units 1 and 2 corresponds to the $0.3 \mathrm{Ma}$ age boundary noted at $\sim 122 \mathrm{mbsf}$ in "Biostratigraphy." These three logging units have no obvious correspondence to lithostratigraphic Units I, II, III, and IV, which were defined on the basis of changes in diatom abundance (see "Lithostratigraphy").

Logging Unit $1(0-122 \mathrm{mbsf})$ is characterized by a well-defined gradual increase in density with depth (from $1.7 \mathrm{~g} / \mathrm{cm}^{3}$ near the seafloor to $2.1 \mathrm{~g} / \mathrm{cm}^{3}$ at 122 mbsf) and a decrease in porosity (from $70 \%$ near the seafloor to $40 \%$ at $122 \mathrm{mbsf}$ ). This increase in density is matched by a corresponding increase in resistivity with depth, from $\sim 1 \Omega \mathrm{m}$ near the seafloor to $\sim 1.5 \Omega \mathrm{m}$ at $122 \mathrm{mbsf}$. The boundary between Units 1 and 2 at 122 mbsf is marked by a sharp decrease in both density (from 2.1 to $1.7 \mathrm{~g} / \mathrm{cm}^{3}$ ) and resistivity (from 1.5 to $1 \Omega \mathrm{m}$ ). This sharp decrease in resistivity is also well defined on the wireline induction data, and it correlates to a decrease in $P$-wave velocity from $\sim 1800$ to $1600 \mathrm{~m} / \mathrm{s}$ (Fig. F53).

Logging Unit 2 (122-250 mbsf) is characterized by a uniform density that averages $\sim 1.9 \mathrm{~g} / \mathrm{cm}^{3}$. In contrast, the resistivity logs in Unit 2 show alternating, thin intervals of high and low resistivity, spanning the range 1-1.5 $\Omega \mathrm{m}$. These thin intervals are especially well defined between 190 and 220 mbsf (Fig. F52). These high and low resistivities are likely to correspond to alternating layers that have high and low gas hydrate concentrations, respectively.

Logging Unit 3 (250-350 mbsf) displays uniform background resistivity $(\sim 1 \Omega \mathrm{m})$ and uniform density $\left(\sim 2 \mathrm{~g} / \mathrm{cm}^{3}\right)$. The most striking feature of this unit is the presence of several borehole enlargements (see the LWD caliper log in Fig. F51) that result in unreliable measurements of natural gamma ray radioactivity, density, and porosity (Fig. F52). Logging Unit 3 displays no obvious resistivity peaks that can be attributed to free gas in the pore fluid. As we are below the GHSZ in this unit, high resistivity should correspond to free gas.

\section{Logging-while-drilling borehole images}

The GeoVISION, ADNVISION, and EcoScope LWD tools generate high-resolution images of borehole log data. The ADNVISION and EcoScope tools produce images of density and hole radius (computed on the basis of the density correction, which de- pends on the borehole standoff). The GeoVISION tool produces a gamma ray image and shallow, medium, and deep depth of investigation resistivity images.

Figure F56 shows some of the images collected by the EcoScope and GeoVISION tools. It should be noted that the display in Figure F56 is highly compressed in the vertical direction. The unwrapped images are $\sim 90 \mathrm{~cm}$ wide (for an 11 inch diameter borehole), and the vertical scale is compressed by a factor of $\sim 37: 1$. These high-resolution images can be used for detailed sedimentological and structural interpretations and to image gas hydrate distribution in sediments (e.g., in layers, nodules, or fractures). Gas hydrate-bearing sediments exhibit high resistivities within intervals of uniform or low bulk density. Layers with high resistivities and high densities are likely to be low-porosity, compacted, or carbonaterich sediments.

The images suggest that there may be high concentrations of gas hydrate in thin, possibly sandy layers between 173 and 240 mbsf in Hole U1325A, where densities are generally low and high-resistivity, gas hydrate-rich layers (bright in the resistivity images of Fig. F56) alternate with low-resistivity layers (dark in the images of Fig. F56) that are likely to contain little or no gas hydrate. The images also show clearly a number of hole enlargements, which appear as dark bands in Figure F56 between 255 and 305 mbsf. These are the same washouts detected by the LWD ultrasonic caliper (Fig. F51).

\section{Logging porosities}

Sediment porosities can be determined from analyses of recovered cores and from downhole measurements (see "Physical properties" and "Downhole logging," both in the "Methods" chapter). The LWD/MWD density and neutron logs from Hole U1325A were used to calculate sediment porosities. Core-derived physical property data, including porosities (see "Physical properties"), were used to both calibrate and evaluate the log-derived sediment porosities.

The LWD log-derived density measurements were used to calculate sediment porosities $(\phi)$ using the standard density-porosity relation

$$
\phi=\left(\rho_{g}-\rho_{b}\right) /\left(\rho_{g}-\rho_{w}\right) .
$$

We used a constant water density $\left(\rho_{\mathrm{w}}\right)$ of $1.03 \mathrm{~g} / \mathrm{cm}^{3}$ and a grain/matrix density $\left(\rho_{\mathrm{g}}\right)$ of $2.75 \mathrm{~g} / \mathrm{cm}^{3}$, which is the average grain density measured in core samples (see "Physical properties"). The density log-derived porosities range from $\sim 60 \%$ at $20 \mathrm{mbsf}$ to $\sim 45 \%$ at 300 mbsf (Fig. F57). In several intervals (0-20, 70100 , and 255-305 mbsf), hole enlargements resulted 
in erroneously low values of density and corresponding porosity values that are too high.

The LWD/MWD neutron porosity log (Fig. F57) yielded porosities ranging from an average value of $\sim 70 \%$ at 20 mbsf to $\sim 55 \%$ at 350 mbsf. As noted earlier, porosities measured by the neutron log are expected to be higher than those computed from the density log in clay-rich sediments because the neutron log essentially measures hydrogen abundance, and hydrogen in clay minerals is counted as porosity. The EcoScope neutron porosity shown in Figure F57 is the "best thermal neutron porosity;" it has been corrected for the effect of clay, so that it is only marginally higher than the density porosity. Like the density porosity, the neutron porosity log also gives values that are too high where the hole is enlarged.

The comparison of core- and LWD-derived porosities in Figure F57 shows agreement throughout the logged interval, with the density porosities being slightly lower and the neutron porosities being slightly higher than the porosities obtained from core samples.

\section{Gas hydrate and free gas occurrence}

As previously discussed (see "Downhole logging" in the "Methods" chapter), the presence of gas hydrate is generally characterized by increases in electrical resistivity and acoustic velocity that are not accompanied by a corresponding decrease in porosity. A decrease in porosity alone in a water-saturated sediment can result in an increase in resistivity and acoustic velocity. Resistivity logging data from Holes U1325A and U1325C show a number of positive resistivity anomalies without a corresponding decrease in porosity (Figs. F52, F53), suggesting that there are several intervals where gas hydrate may be present.

\section{Water saturations from Archie's equation}

To estimate the amount of gas hydrate at Site U1325, we used the Archie relation (e.g., Collett and Ladd, 2000)

$$
S_{\mathrm{w}}=\left[\left(a \times R_{\mathrm{w}}\right) /\left(\phi^{\mathrm{m}} \times R_{\mathrm{t}}\right)\right]^{1 / n},
$$

where

$$
\begin{aligned}
S_{\mathrm{w}}= & \text { water saturation, } \\
a= & \text { tortuosity coefficient, } \\
R_{\mathrm{w}}= & \text { formation water resistivity, } \\
\phi= & \text { density porosity computed from the ADNVI- } \\
& \text { SION enhanced resolution bulk density, } \\
m= & \text { cementation coefficient, and } \\
R_{\mathrm{t}}= & \text { GeoVISION high-resolution button deep av- } \\
& \text { erage resistivity, and } \\
n= & \text { saturation coefficient. }
\end{aligned}
$$

We used the button deep resistivity instead of the ring resistivity because the button deep resistivity matches the resistivities with the greatest depth of investigation measured by the EcoScope tool (except for having a higher resolution), whereas the ring resistivity values are generally lower than the EcoScope deep resistivities.

Gas hydrate saturation $\left(S_{\mathrm{h}}\right)$ is the percentage of pore space in the sediment that is occupied by gas hydrate. It is the complement of the water saturation $S_{\mathrm{w}}$ :

$$
S_{\mathrm{h}}=1-S_{\mathrm{w}}
$$

The procedure to estimate $S_{\mathrm{w}}$ with Archie's relation is illustrated in Figure F58. We first computed porosity from the density log as described above with a water density $\left(\rho_{\mathrm{w}}\right)$ of $1.03 \mathrm{~g} / \mathrm{cm}^{3}$ and a grain/matrix density $\left(\rho_{\mathrm{g}}\right)$ of $2.75 \mathrm{~g} / \mathrm{cm}^{3}$ (see "Physical properties").

To estimate the formation water resistivity $\left(R_{\mathrm{w}}\right)$, we started by constructing a salinity versus depth function based on IW salinity measurements (see "Interstitial water geochemistry"). This salinity versus depth function consists of two linear segments fitted to the data (0-20 mbsf and below $20 \mathrm{mbsf})$. At every logging depth, we combined the salinity value with a formation temperature obtained from the geothermal gradient estimated from the downhole temperature measurements (see "In situ temperature profile"), and used the formulas of Fofonoff (1985) to obtain the corresponding value of the water resistivity.

To estimate the water saturation $\left(S_{\mathrm{w}}\right)$ we also need to choose values for the Archie coefficients $a$ and $m$. One way to do this is to choose a logged interval where the sediments can be assumed to be water saturated and fit $a$ and $m$ to a plot of measured resistivity versus porosity, known as a "Pickett plot" (e.g., Doveton, 1994). In marine sediments, however, the range of porosity is relatively small and it is not possible to obtain a robust estimate of both $a$ and $m$. We prefer to set $a=1$, which is physically the most realistic value because it gives a resistivity equal to the formation water resistivity when the porosity is $100 \%$. We then compute an "estimated $m$ " coefficient by

$$
m_{\text {est }}=-\log (F) / \log (\phi),
$$

where $F=\left(R_{\mathrm{t}} / R_{\mathrm{w}}\right)$ is the formation factor. This $m_{\text {est }}$ curve should give the appropriate value to be used in Archie's equation in water-saturated intervals and will give anomalously high values in intervals that contain hydrocarbons. A reasonable value of $m=2.5$ can be chosen from the baseline trend of the $m_{\text {est }}$ curve in Figure F58. 
The next step is to compute the resistivity $R_{0}$ predicted by Archie's equation for a water-saturated formation of a given porosity, which is given by

$$
R_{0}=\left(a \times R_{\mathrm{w}}\right) / \phi^{m} \text {. }
$$

Using Archie coefficients of $a=1$ and $m=2.5$, we computed an $R_{0}$ curve that generally follows the measured resistivity $R_{\mathrm{t}}$ but is significantly lower than $R_{\mathrm{t}}$ in several intervals, mostly in logging Unit 2 (Fig. F58). Finally, we computed the water saturation $S_{\mathrm{w}}$ using a saturation coefficient $n=2$.

As noted earlier, several hole enlargements resulted in logging density values that are erroneously low and approach water density. In the Archie interpretation, these low densities translate into artificially high porosities, low values for the predicted watersaturated resistivity $R_{0}$, and low values of water saturation $S_{w}$. These anomalous intervals should be ignored and are marked by gray overlays in Figure F58.

Figure F58 shows a clear interval between 100 and 255 mbsf where the measured resistivity $R_{\mathrm{t}}$ occasionally exceeds the resistivity $R_{0}$ predicted for water-saturated conditions and where the inferred water saturations can be as low as $40 \%$. This interval encompasses the bottom of logging Unit 1 and all of Unit 2, and the high-resolution LWD porosity and resistivity logs used in Figure F58 show that it is heterogeneous, being composed by many alternating layers of highly variable porosity and resistivity. We interpret the 100-255 mbsf interval as a sequence of thin, gas hydrate-rich layers intercalated with layers that may contain little or no gas hydrate. This interpretation is in general agreement with the marked pore water freshening observed in sand layers compared to lower degrees of freshening in clay-rich layers (see the pore water salinity data in Fig. F58 and "Interstitial water geochemistry").

\section{Comparison with infrared images}

The IR core images taken on the catwalk measure the core liner temperature, and cold anomalies in the IR images caused by gas hydrate dissociation give an independent "map" of gas hydrate concentrations (see "Physical properties"). Figure F59 shows a comparison of the LWD and wireline resistivity logs with the IR images. Some of the IR cold temperature anomalies correlate with layers of high resistivity. For example, the IR images show a cold interval at 148-152 mbsf that corresponds to a high-resistivity interval on the LWD logs. Whereas the IR images show cold temperatures at 186-189 mbsf, in the hydrate-rich interval defined by high resistivities poor core recovery does not allow us to check how closely IR cold temperatures correlate with high resistivities.

\section{Temperature data}

The LDEO TAP tool was deployed on the DSI/SGT tool string in Hole U1325C (Fig. F60). During the process of coring and drilling, cold seawater is circulated in the hole, cooling the formation surrounding the borehole. Once drilling ceases, the temperature of the fluid in the borehole gradually rebounds to the in situ equilibrium formation temperature. Thus, the temperature data from the TAP tool cannot be immediately used to assess the in situ formation temperature. Because we were not able to run a caliper log in Hole U1325C, we cannot relate temperature gradient changes in Figure F60 to changes in hole diameter. The most prominent feature in Hole U1325C (Fig. F60) is the sudden temperature step at 80 mbsf (in the downhole trip) and 75 mbsf (in the uphole trip), which take place when the TAP tool exits and enters the drill pipe.

\section{References}

Aldred, W., Cook, J., Bern, P., Carpenter, B., Hutchinson, M., Lovell, J., Rezmer-Cooper, I., and Leder, P.C., 1998. Using downhole annular pressure measurements to improve drilling performance. Oilfield Rev., 10(4):40-55.

Chapman, N.R., Gettrust, J.F., Walia, R., Hannay, D., Spence, G.D., Wood, W.T., and Hyndman, R.D., 2002. High-resolution, deep-towed, multichannel seismic survey of deep-sea gas hydrates off western Canada. Geophysics, 67(4):1038-1047. doi:10.1190/1.1500364

Collett, T.S., and Ladd, J., 2000. Detection of gas hydrate with downhole logs and assessment of gas hydrate concentrations (saturations) and gas volumes on the Blake Ridge with electrical resistivity log data. In Paull, C.K., Matsumoto, R., Wallace, P.J., and Dillon, W.P. (Eds.), Proc. ODP, Sci. Results, 164 [Online]. Available from World Wide Web: http://www-odp.tamu.edu/publications/164_SR/chap_19/chap_19.htm.

Collett, T.S., Riedel, M., Malone, M.J., and the Expedition 311 Project Team, 2005. Cascadia margin gas hydrates. IODP Sci. Prosp., 311. doi:10.2204/iodp.sp.311.2005

Davis, E.E., Hyndman, R.D., and Villinger, H., 1990. Rates of fluid expulsion across the northern Cascadia accretionary prism: constraints from new heat flow and multichannel seismic reflection data. J. Geophys. Res., 95:8869-8889.

Doveton, J.H., 1994. Geologic log analysis using computer methods. AAPG Comp. Appl. Geol., 2:169.

Fofonoff, N.P., 1985. Physical properties of seawater: a new salinity scale and equation of state for seawater. J. Geophys. Res., 90:3332-3342.

Hoehler, T.M., Alperin, M.J., Albert, D.B., and Martens, C.S., 1994. Field and laboratory studies of methane oxidation in anoxic marine sediment: evidence for a methanogen-sulfate reducer consortium. Global Biogeochem. Cycles, 8:451-463. doi:10.1029/94GB01800 
Hyndman, R.D., and Davis, E.E., 1992. A mechanism for the formation of methane hydrate and seafloor bottomsimulating reflectors by vertical fluid expulsion. J. Geophys. Res., 97:7025-7041.

Hyndman, R.D., Spence, G.D., Chapman, N.R., Riedel, M., and Edwards, R.N., 2001. Geophysical studies of marine gas hydrate in northern Cascadia. In Paull, C.K., and Dillon, W.P. (Eds.), Natural Gas Hydrates, Occurrence, Distribution and Detection. Geophys. Monogr., 124:273-295.

MacKay, M.E., Jarrard, R.D., Westbrook, G.K., and Hyndman, R.D., 1994. Origin of bottom-simulating reflectors: geophysical evidence from the Cascadia accretionary prism. Geology, 22(5):459-462. doi:10.1130/0091-7613(1994)022<0459:OOBSRG >2.3.CO;2

Pimmel, A., and Claypool, G., 2001. Introduction to shipboard organic geochemistry on the JOIDES Resolution. ODP Tech. Note, 30 [Online]. Available from World Wide Web: http://www-odp.tamu.edu/publications/ tnotes/tn30/INDEX.HTM.
Riedel, M., Long, P., Liu, C.S., Schultheiss, P., Collett, T., and ODP Leg 204 Shipboard Scientific Party, 2006. Physical properties of near-surface sediments at southern Hydrate Ridge: results from ODP Leg 204. In Tréhu, A.M., Bohrmann, G., Torres, M.E., and Colwell, F.S. (Eds.), Proc. ODP, Sci. Results, 204 [Online]. Available from World Wide Web: http://www-odp.tamu.edu/ publications/204_SR/104/104.htm.

Ruppel, C.D., 2000. Thermal state of the gas hydrate reservoir. In Max, M.D. (Ed.), Natural Gas Hydrate in Oceanic Permafrost Environments. Coastal Syst. Cont. Margins, 5:29-42.

Sloan, E.D., 1998. Clathrate Hydrates of Natural Gases (2nd ed.): New York (Marcel Dekker).

$\mathrm{Xu}, \mathrm{W} ., 2002$. Phase balance and dynamic equilibrium during formation and dissociation of methane gas hydrate. Fourth Int. Conf. Gas Hydrates, 19023:199-200.

$\mathrm{Xu}, \mathrm{W} ., 2004$. Modeling dynamic marine gas hydrate systems. Am. Mineral., 89:1271-1279.

Publication: 28 October 2006

MS 311-103 
Figure F1. Location of site survey data for Site U1325 (proposed Site CAS-02C). Positions of common depth points (CDPs) of multichannel seismic (MCS) data and shot points of single-channel seismic (SCS) data are shown. Site U1325 is situated at the crossing point of MCS Lines 89-08 and PGC9902_ODP-7 with SCS Line CAS02B_05_04. Axes are Universal Transverse Mercator (UTM) projection easting and northing coordinates using the WGS-84 reference.

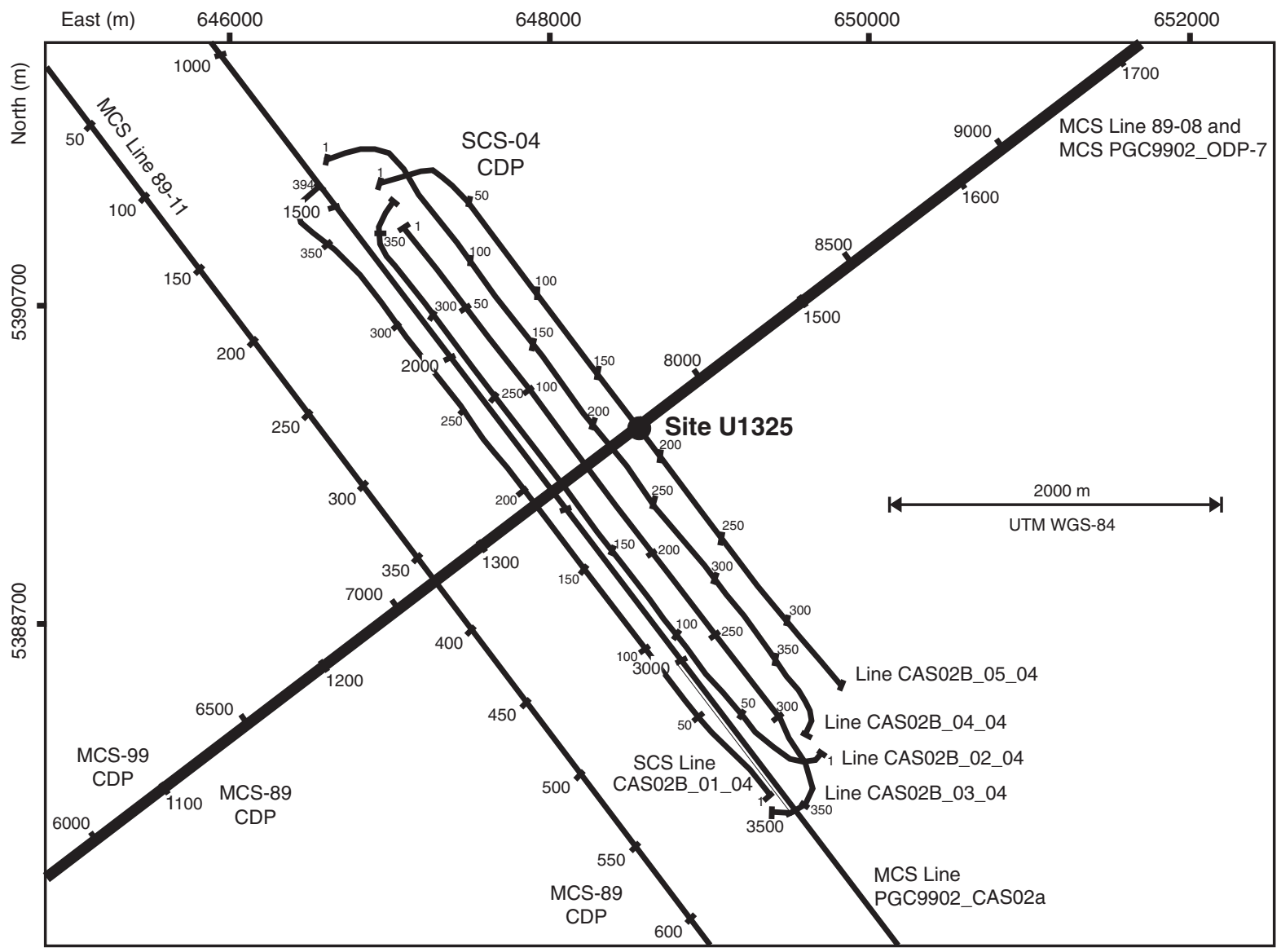


Figure F2. Section of multichannel seismic Line 89-08 over Site U1325. The data are of low seismic frequency content from 10 to $50 \mathrm{~Hz}$. A buried ridge of accreted sediments can be identified between common depth points (CDPs) 1320 and 1440, covered by a thin interval of slope basintype sediments that onlap onto the ridge. A bright spot is identified underneath the center of the ridge, potentially indicating the presence of free gas. A strong bottom-simulating reflector (BSR) is seen over much of the eastern section of the basin, whereas it disappears underneath the western part of the basin, which is filled with as much as $600 \mathrm{~ms}$ two-way traveltime (TWT) thick slope basin-type sediments. Site U1325 intersects an interval of $300 \mathrm{~ms}$ TWT thickness where sediments show a strong eastward dip. V.E. = vertical exaggeration.

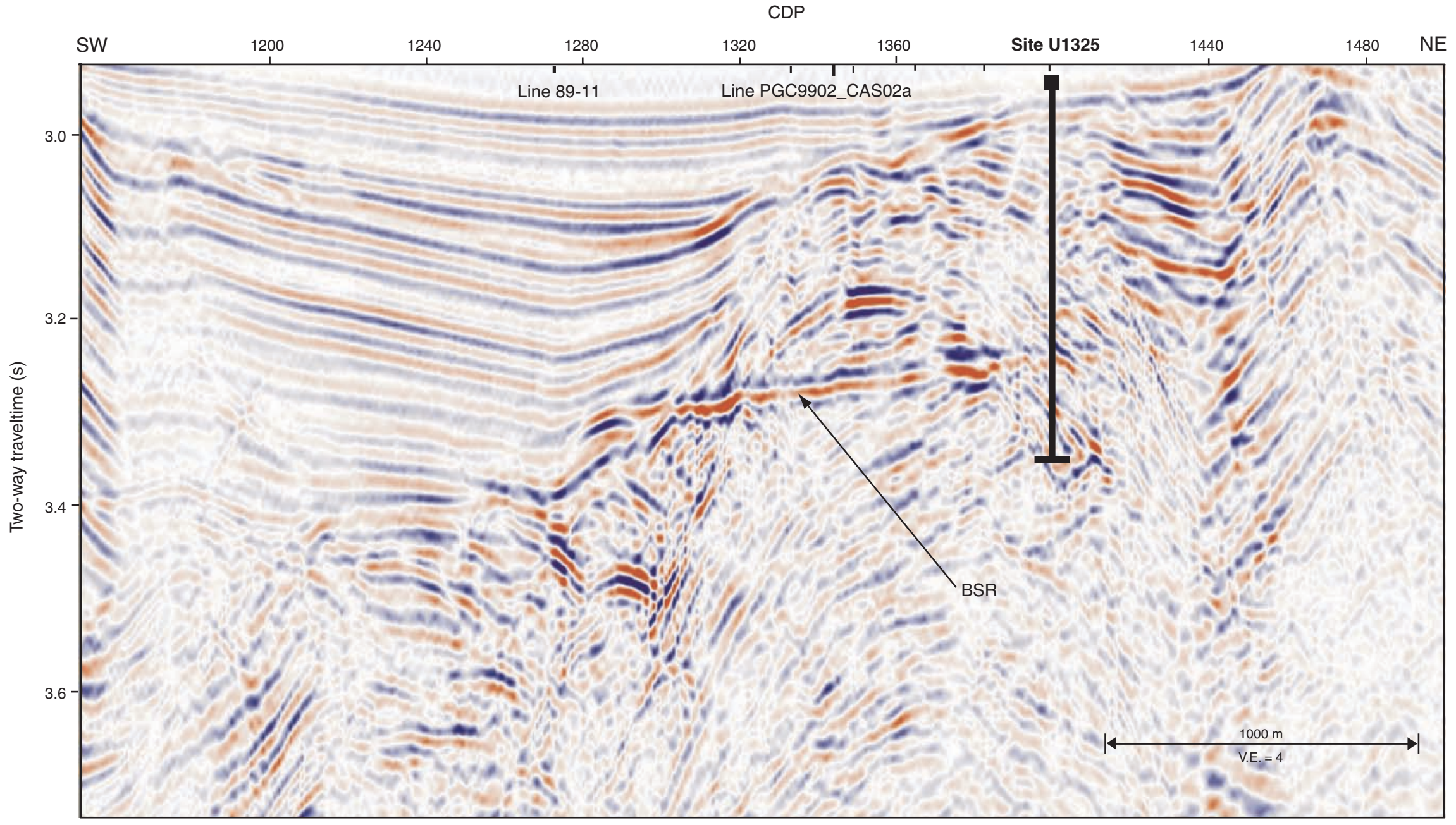


Figure F3. Section of $3.5 \mathrm{kHz}$ high-resolution subbottom profiler data along Line PGC9902_ODP-7. The data show a thin, $3-5 \mathrm{~m}$ thick transparent layer of sediments on top of high-reflectivity material without any further internal layering. Near the intersection point with multichannel seismic Line PGC9902_CAS02a, a small blank zone can be identified that may be linked to the bright spot observed in the lower frequency seismic data of Line 89-08. V.E. = vertical exaggeration.

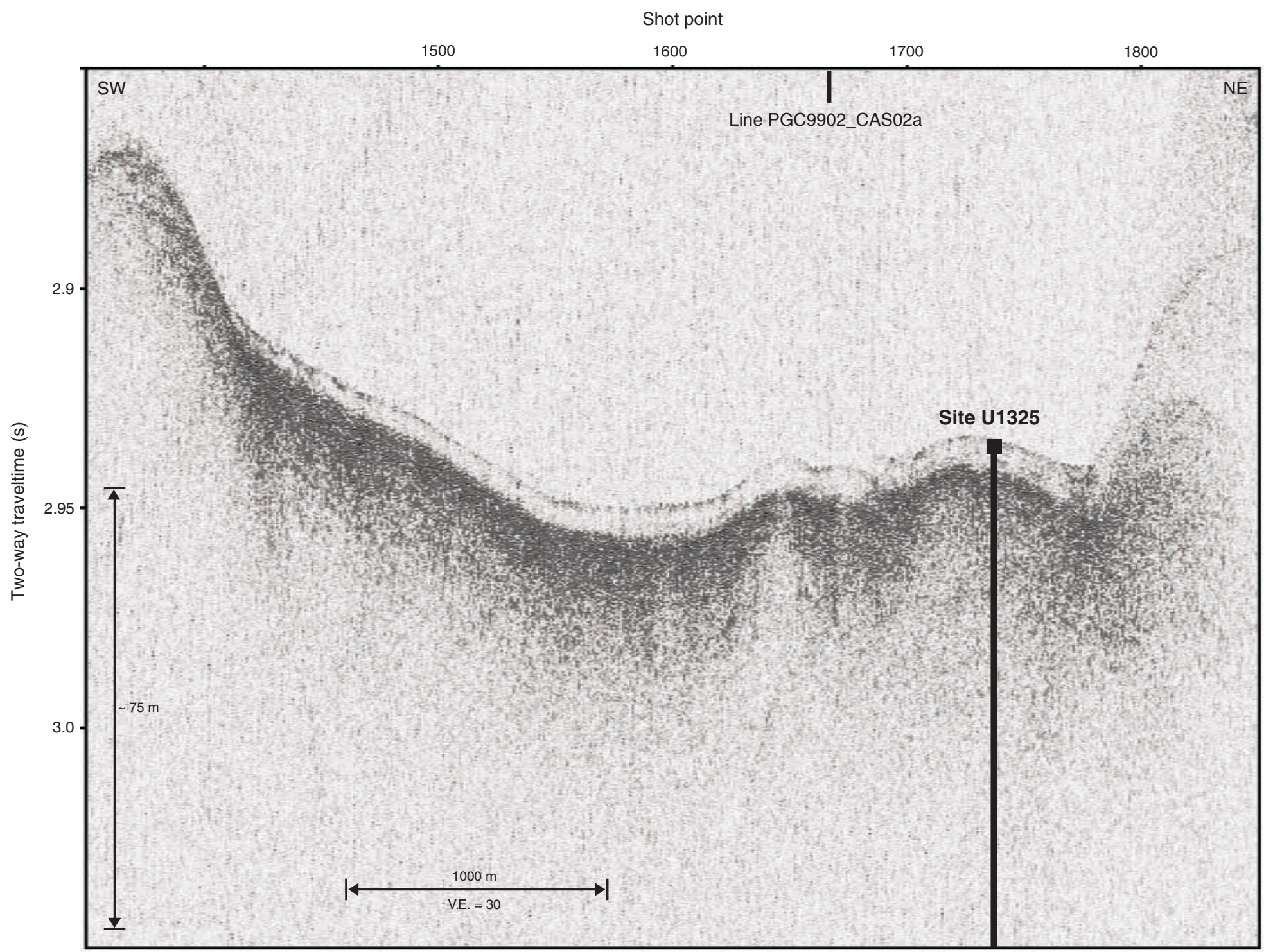


Figure F4. Section of multichannel seismic Line PGC9902_ODP-7. The data have a twice as high frequency content than those from Line 89-08 (Fig. F2). The bottom-simulating reflector (BSR) is much weaker in these data, especially at Site U1325. The data set shows a bright reflector at $\sim 10$ mbsf. Underneath this reflector, steeply eastward dipping sediments are observed over almost the entire sediment column cored. CDP $=$ common depth point, V.E. = vertical exaggeration.

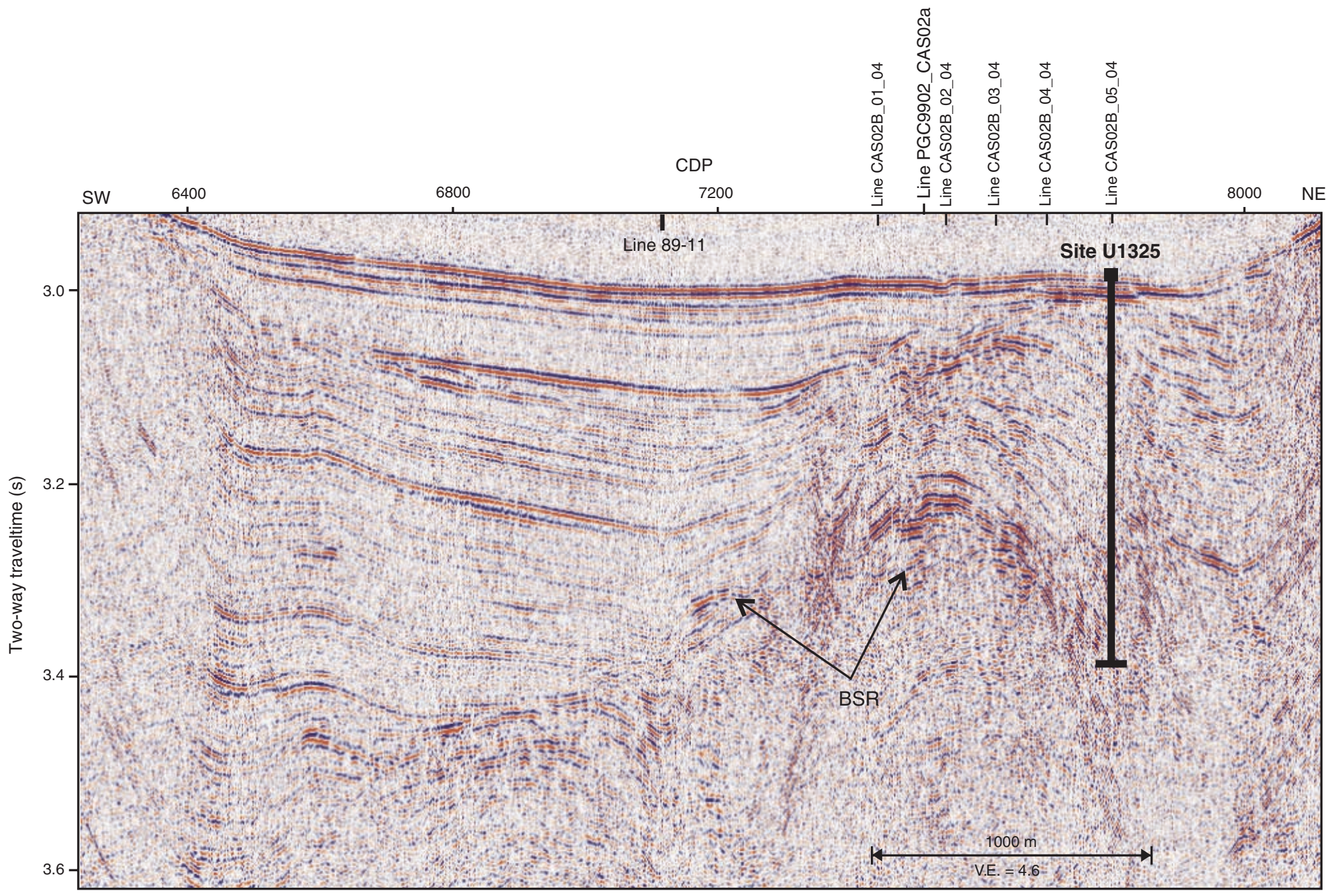


Figure F5. Section of single-channel seismic Line CAS02B_05_04 crossing Lines 89-08 and PGC9902_ODP-7 in a perpendicular direction. CDP = common depth point, V.E. = vertical exaggeration.

CDP

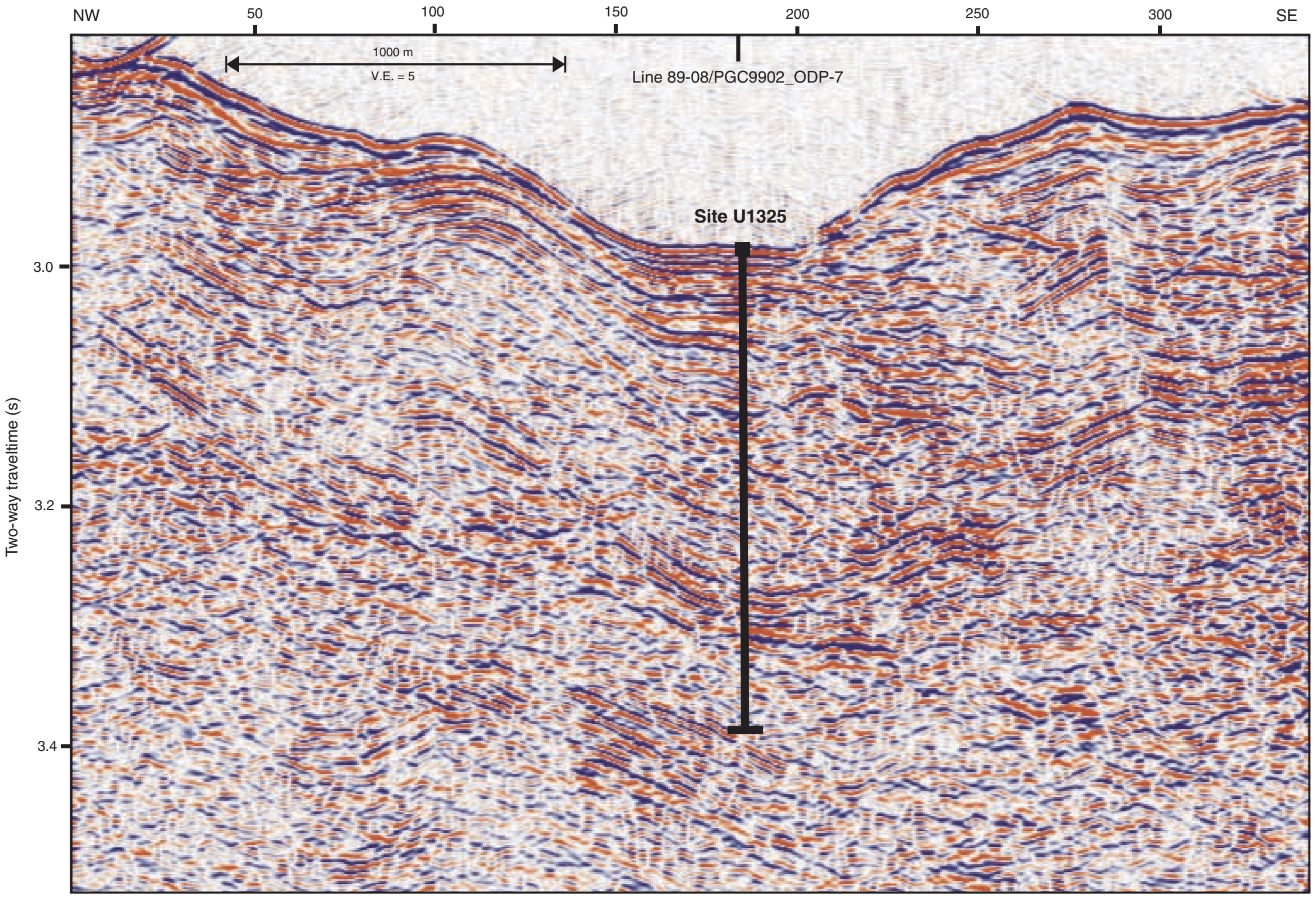


Figure F6. Location of holes drilled at Site U1325, showing track lines with seismic survey shot points. Axes are universal transverse Mercator (UTM) projection easting and northing coordinates using the WGS-84 reference. $\mathrm{MCS}=$ multichannel seismic, SCS = single-channel seismic.

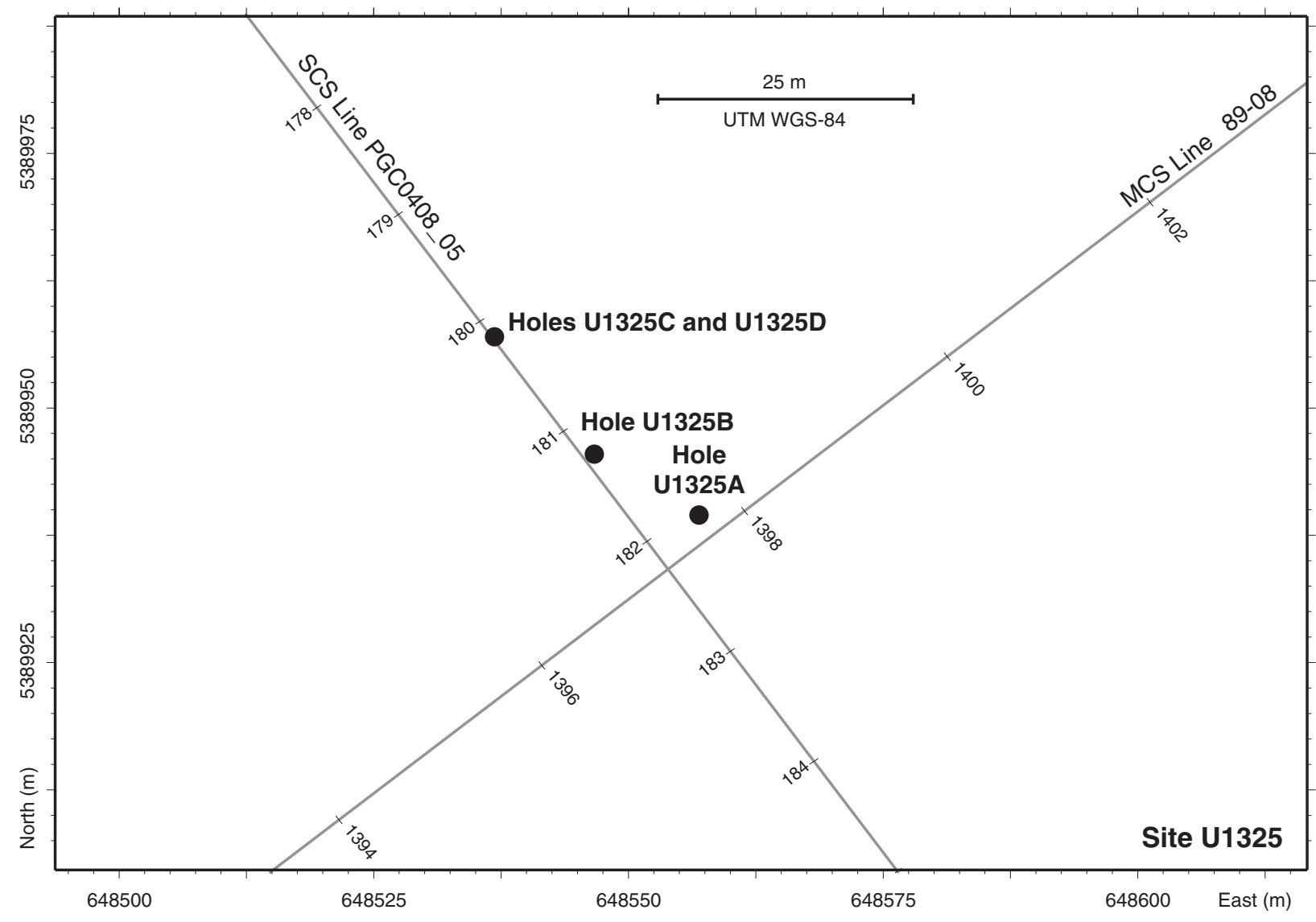


Figure F7. Lithostratigraphic summary for Holes U1325B (solid circles) and U1325C (open squares) showing the percentage of clay, silt, sand, biogenic opal (diatoms, radiolarians, siliceous spicules, silicoflagellates), foraminifers, and nannofossils in the major lithology; clay, silt, and sand in the minor lithology; and AMST color reflectance. Samples in brackets are interpreted as outliners and were not used in defining the lithostratigraphic units.
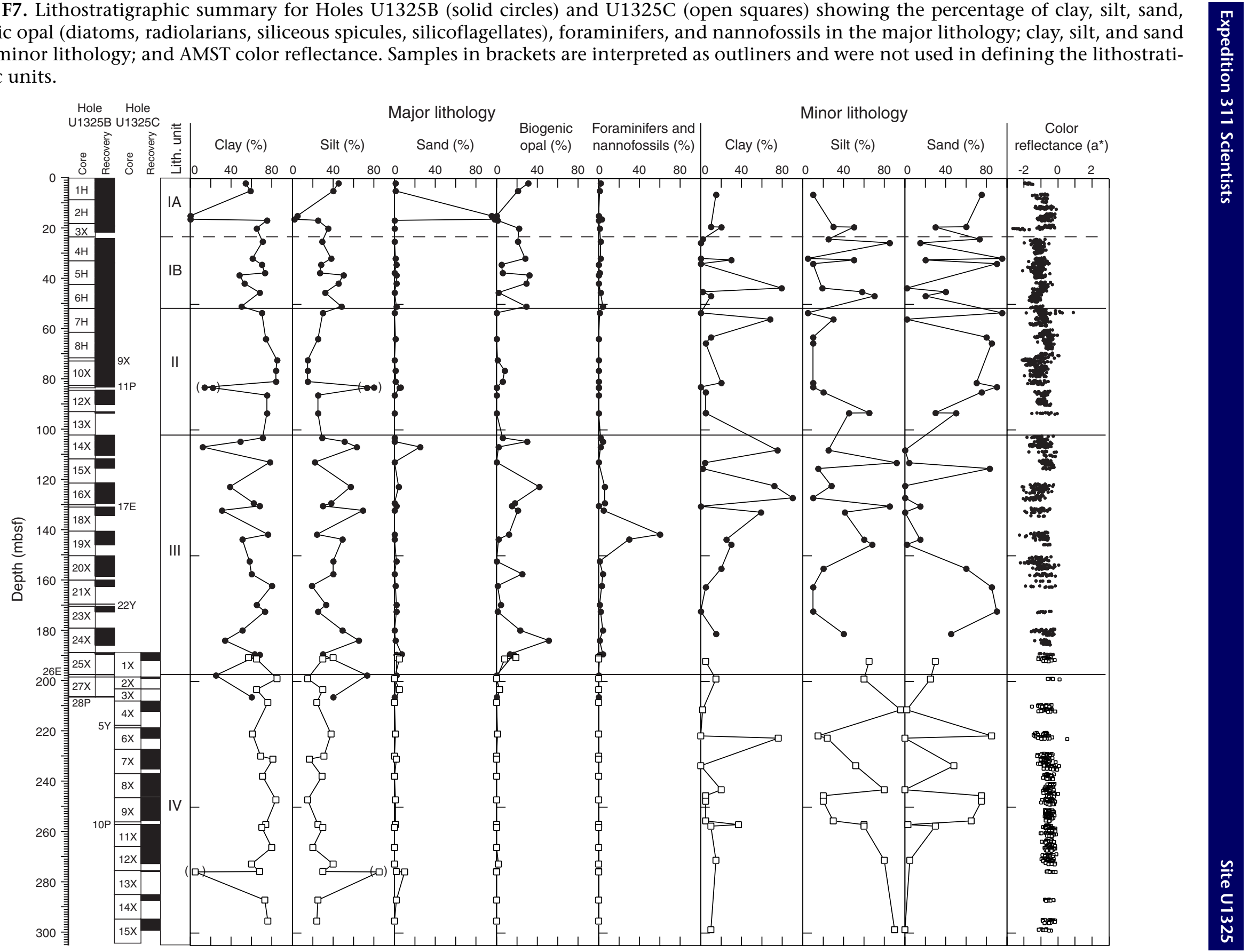
Figure F8. Black sand with a sharp, lower boundary to dark greenish gray silty clay in lithostratigraphic Subunit IA (interval 311-U1325B-2H-4, 68-102 cm). The cracks are caused by the drying of the core.

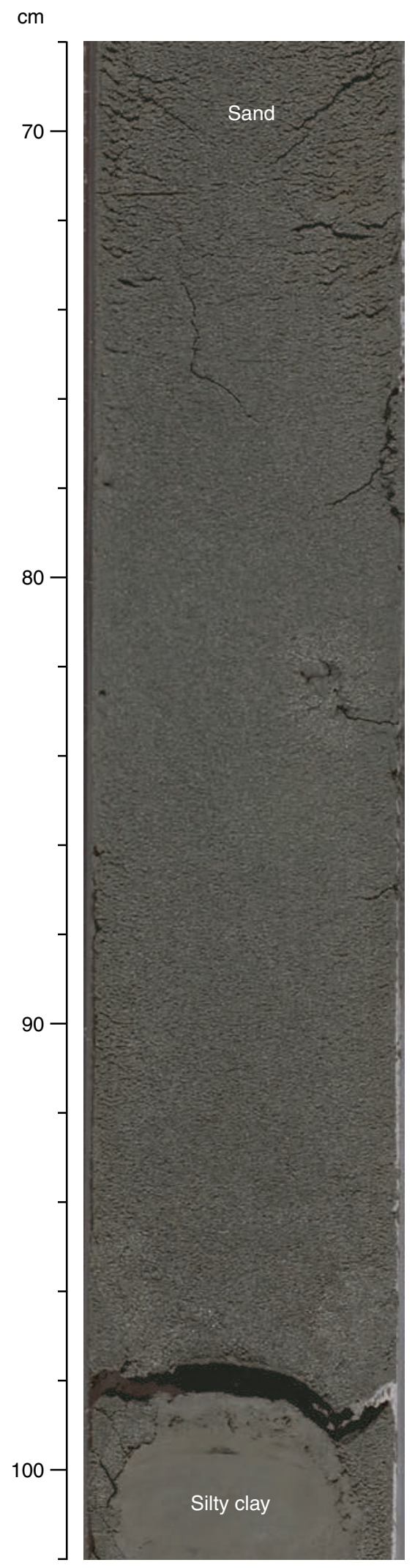


Figure F9. Dark greenish gray silty clay with diatoms and multiple interlayers of different colored sands in lithostratigraphic Subunit IA (interval 311-U1325B-1H-7, 14-34 cm).

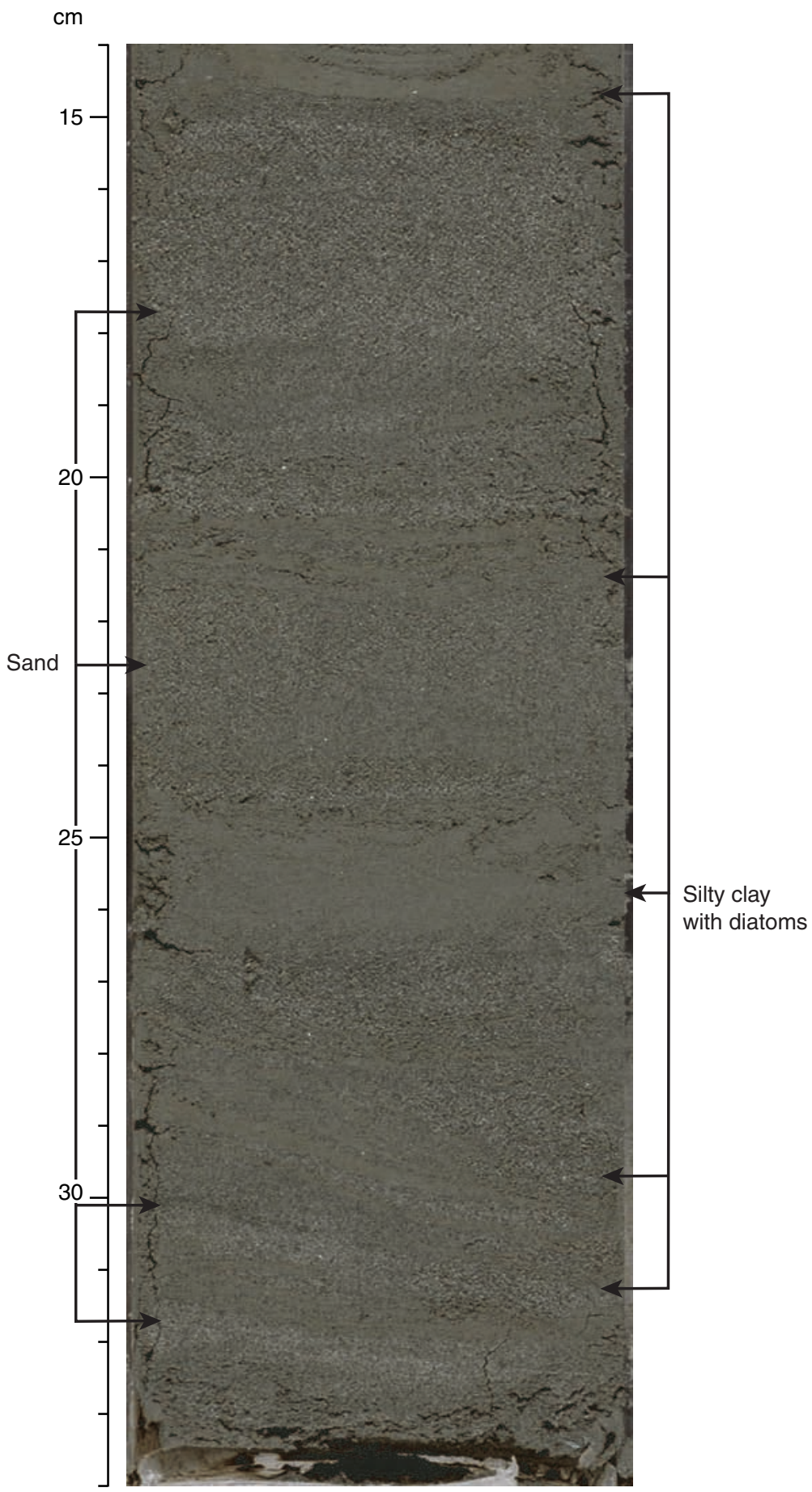


Figure F10. Dark greenish gray silty clay with several dropstones of different color and composition in lithostratigraphic Subunit IA (interval 311-U1325B-2H-7, 33-59 cm).

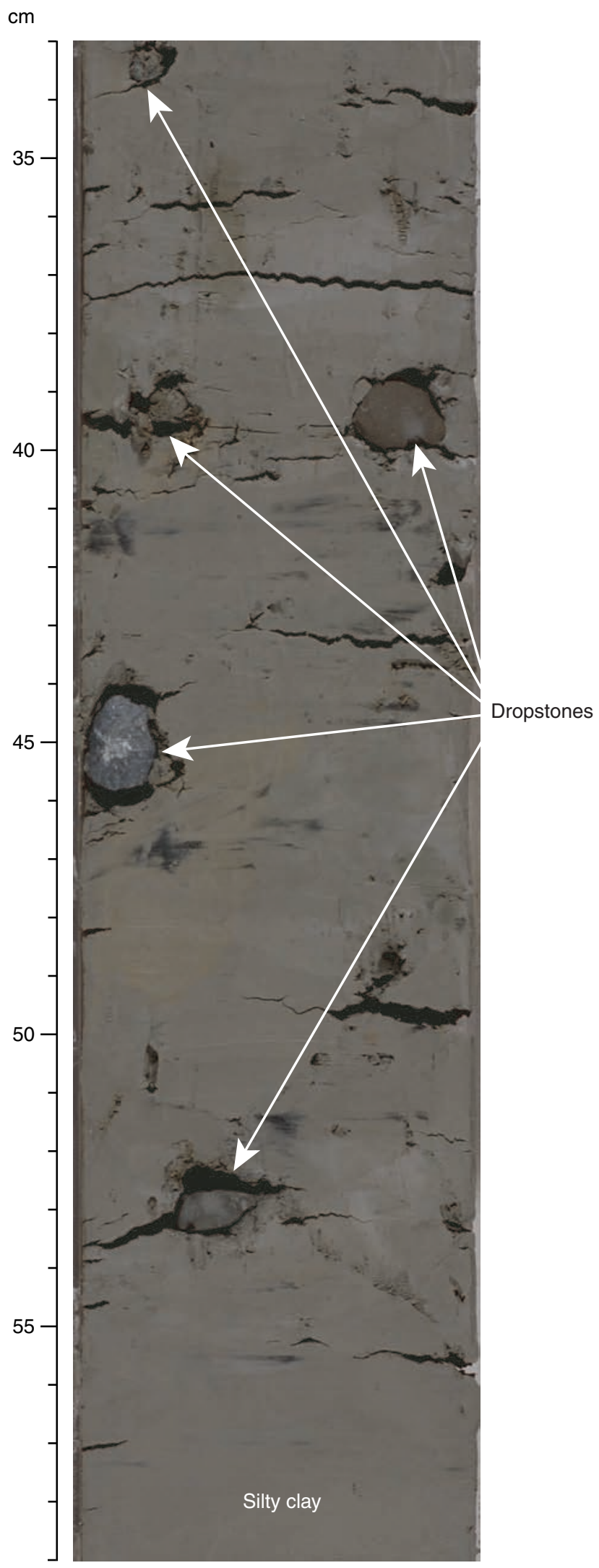


Figure F11. Dark greenish gray silty clay with a $\sim 2 \mathrm{~cm}$ thick lens of volcanic ash in lithostratigraphic Subunit IB (interval 311-U1325B-6H-3, 60-78 cm).

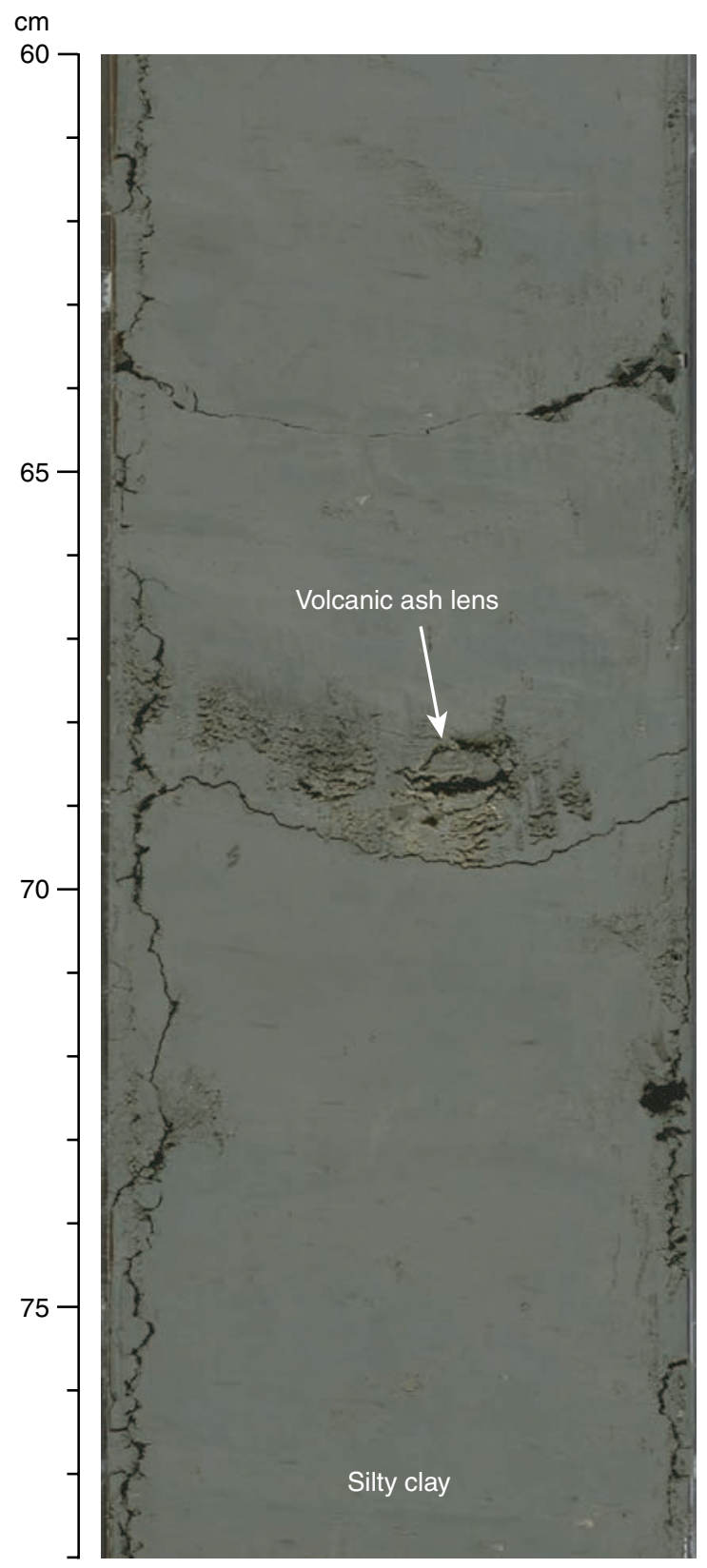


Figure F12. Dark greenish gray silty clay with diatoms, abundant sulfide mottles, and bioturbation below a 3 $\mathrm{cm}$ thick layer of silty sand in lithostratigraphic Subunit IB (interval 311-U1325B-4H-1, 5-30 cm).

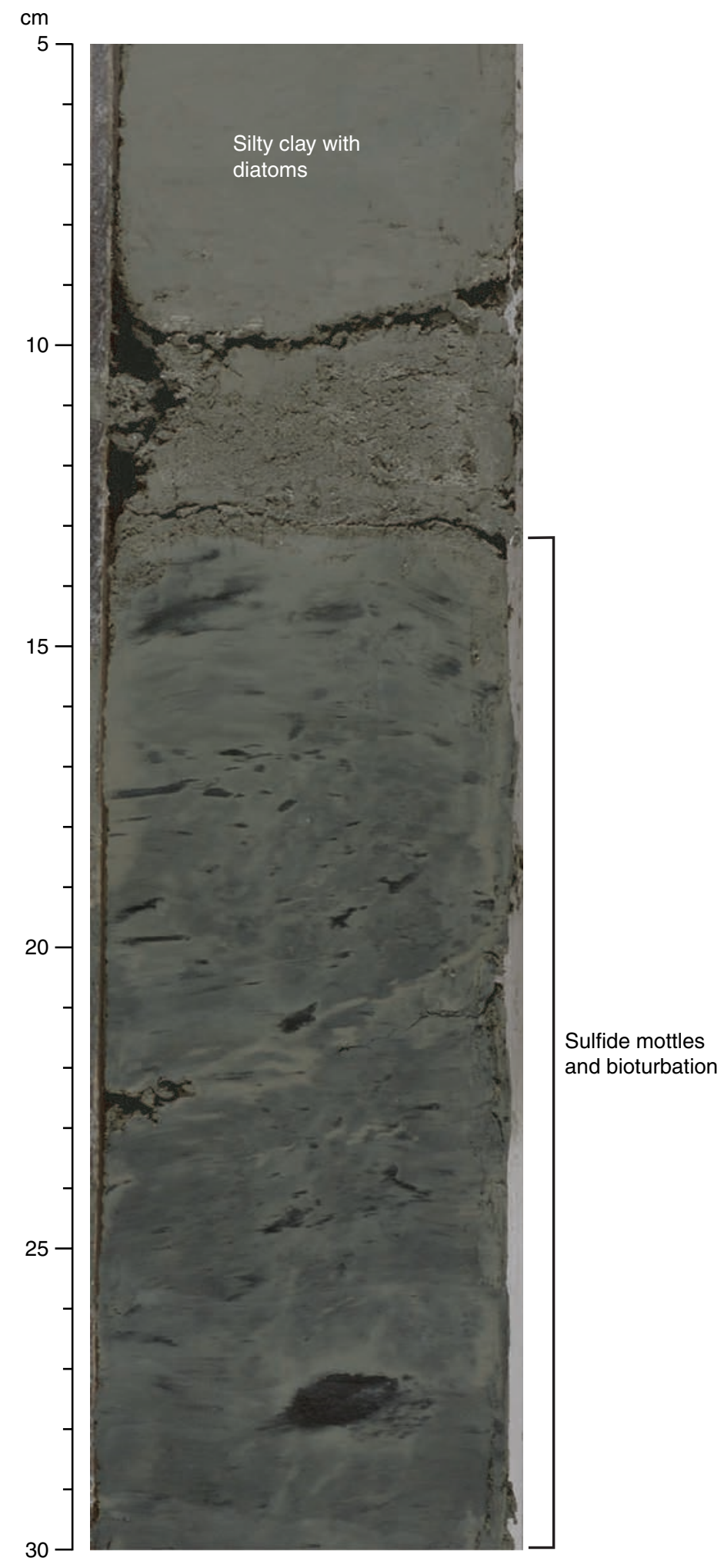


Figure F13. Aggregates of sponge spicules within dark greenish gray silty clay with diatoms in lithostratigraphic Subunit IB (interval 311-U1325B-4H-2, 13-30 cm).

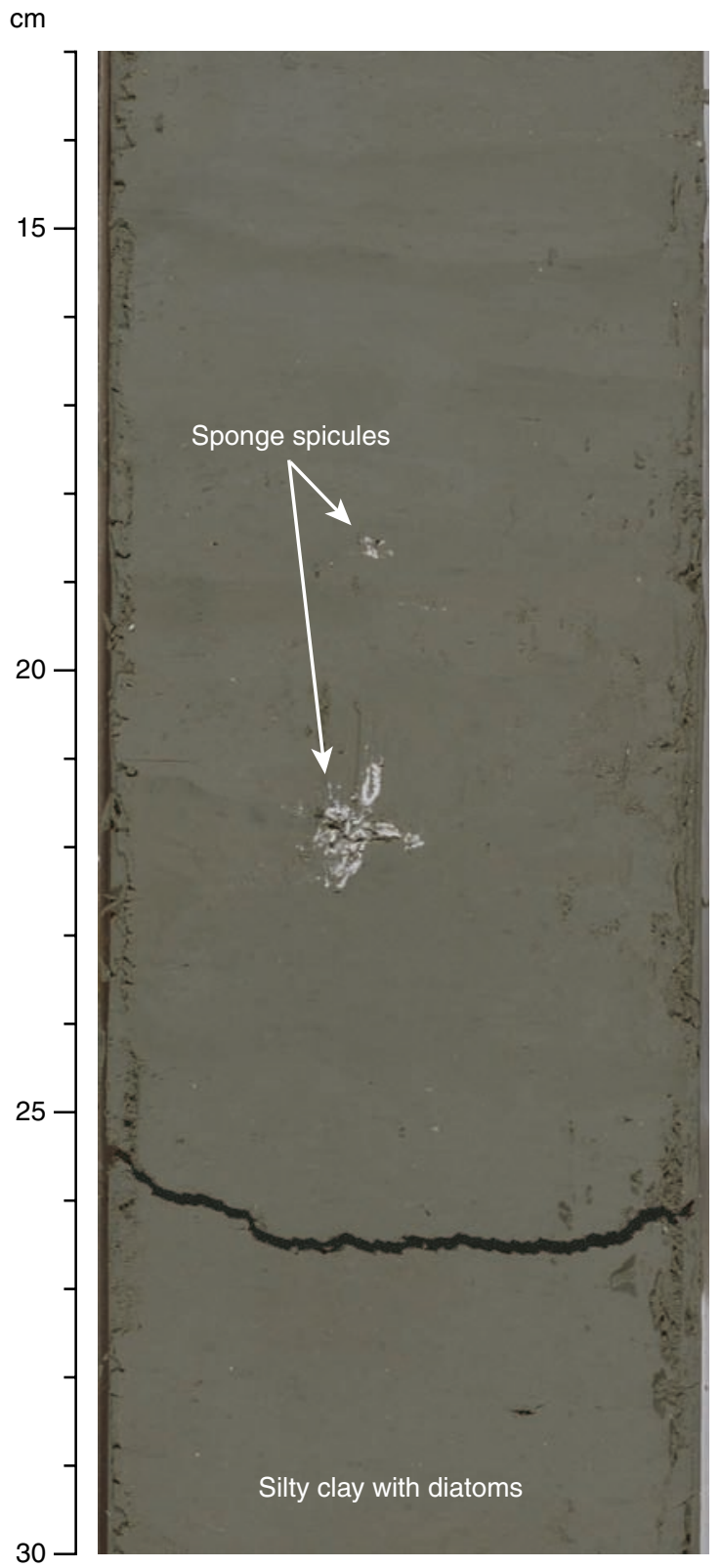


Figure F14. Sponge spicules in Subunit IB (Sample 311-U1325B-4H-2, 23 cm).

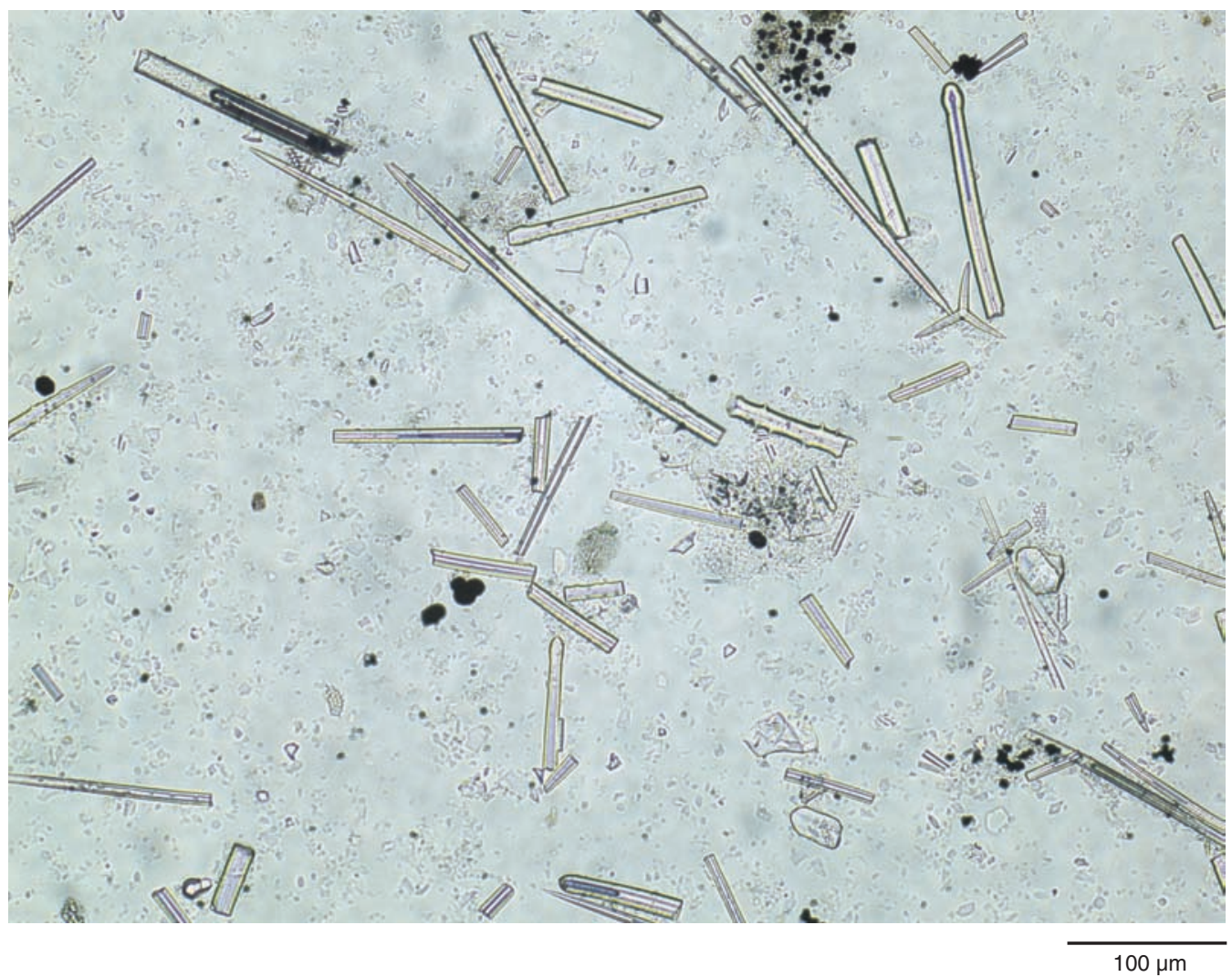


Figure F15. Dark gray silty clay with multiple, differently colored quartz sand layers in lithostratigraphic Subunit IB (interval 311-U1325B-8H-4, 44-67 cm).

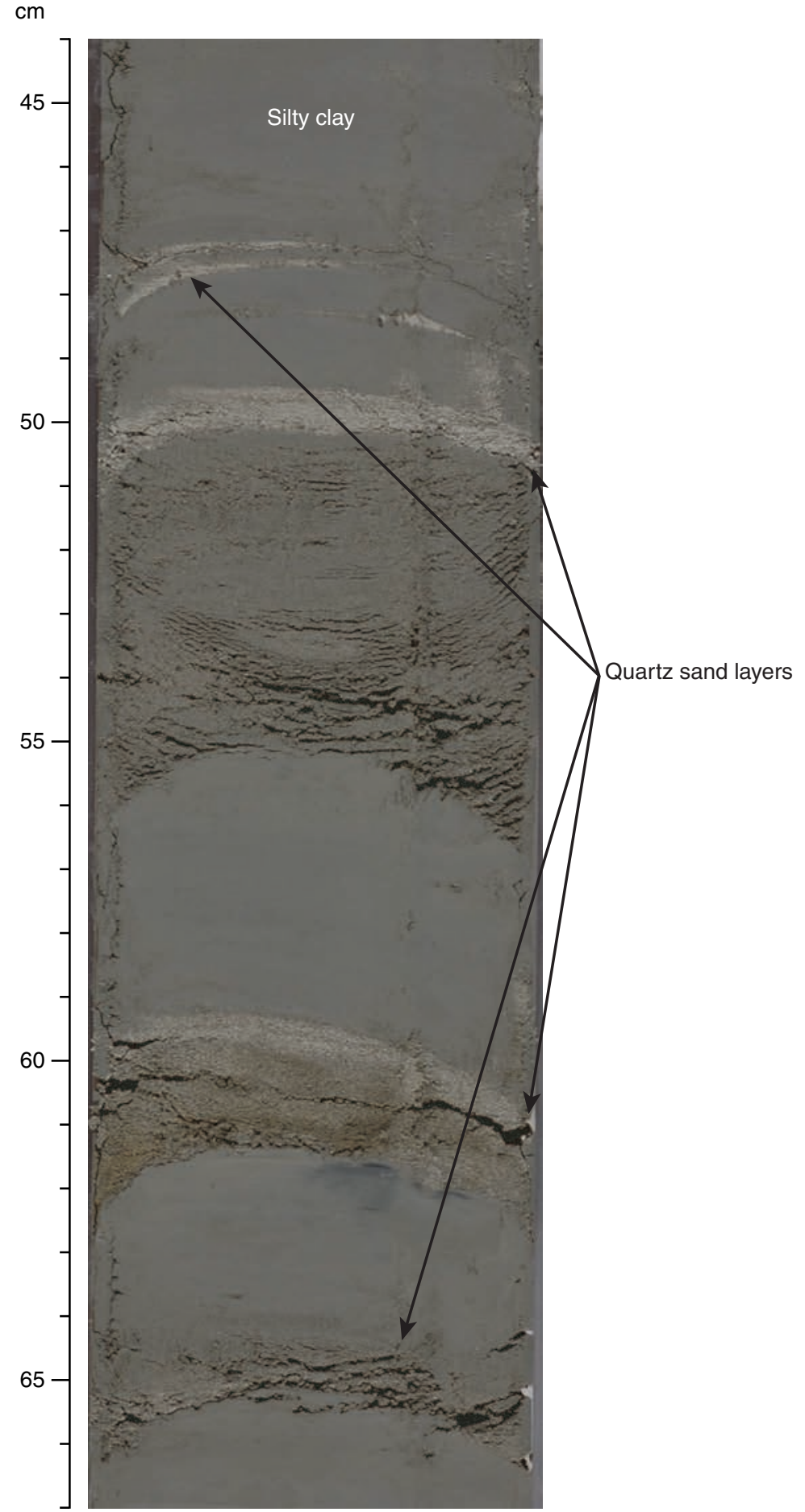


Figure F16. Planar laminations within dark gray clay in lithostratigraphic Unit III (interval 311-U1325B-15X$3,23-45 \mathrm{~cm})$.

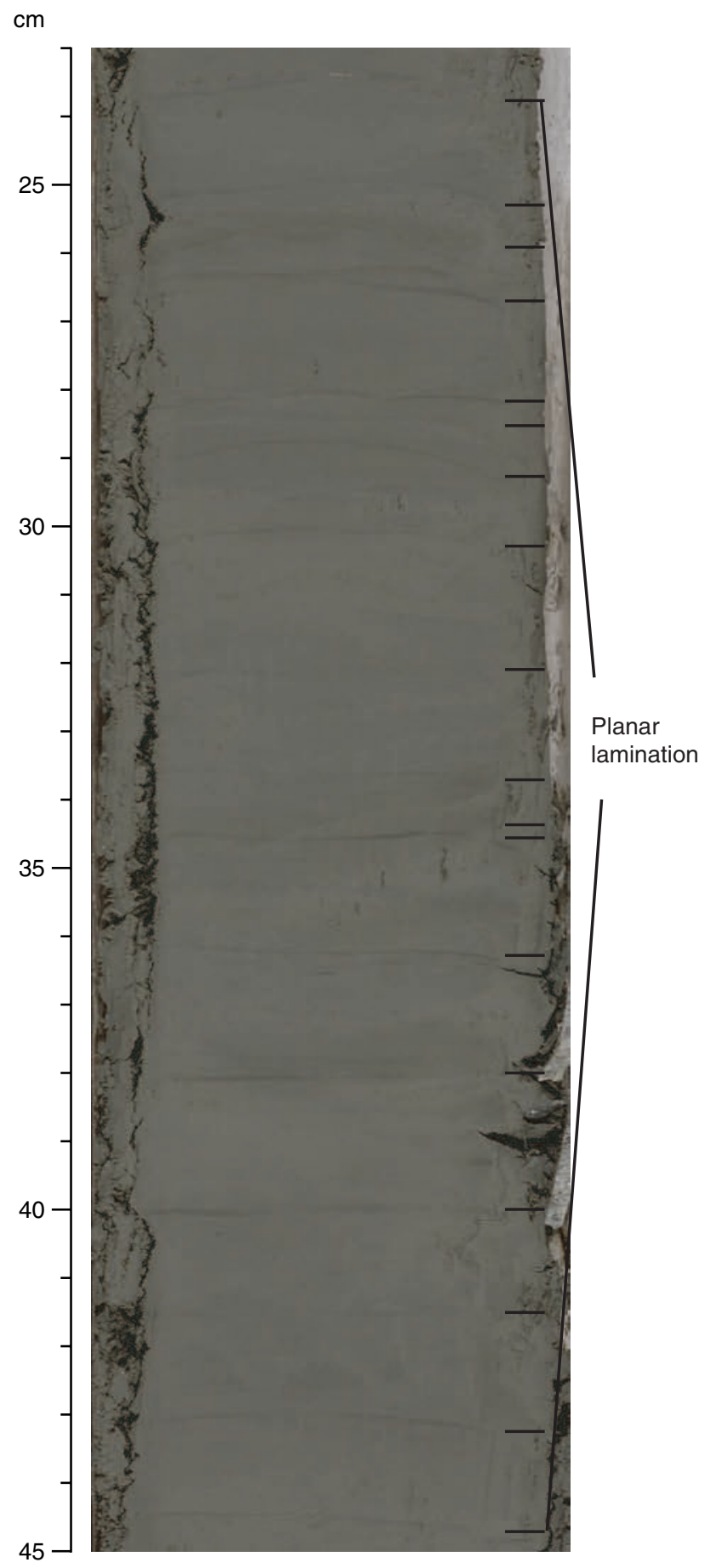


Figure F17. Nannofossil ooze in lithostratigraphic Unit III (Sample 311-U1325B-19X-1, 100 cm). Coccoliths appear in polarized light as elliptical white shapes with black crosses inside; some are very large (arrows), but most are $2-3 \mu \mathrm{m}$ wide (small bright spots).

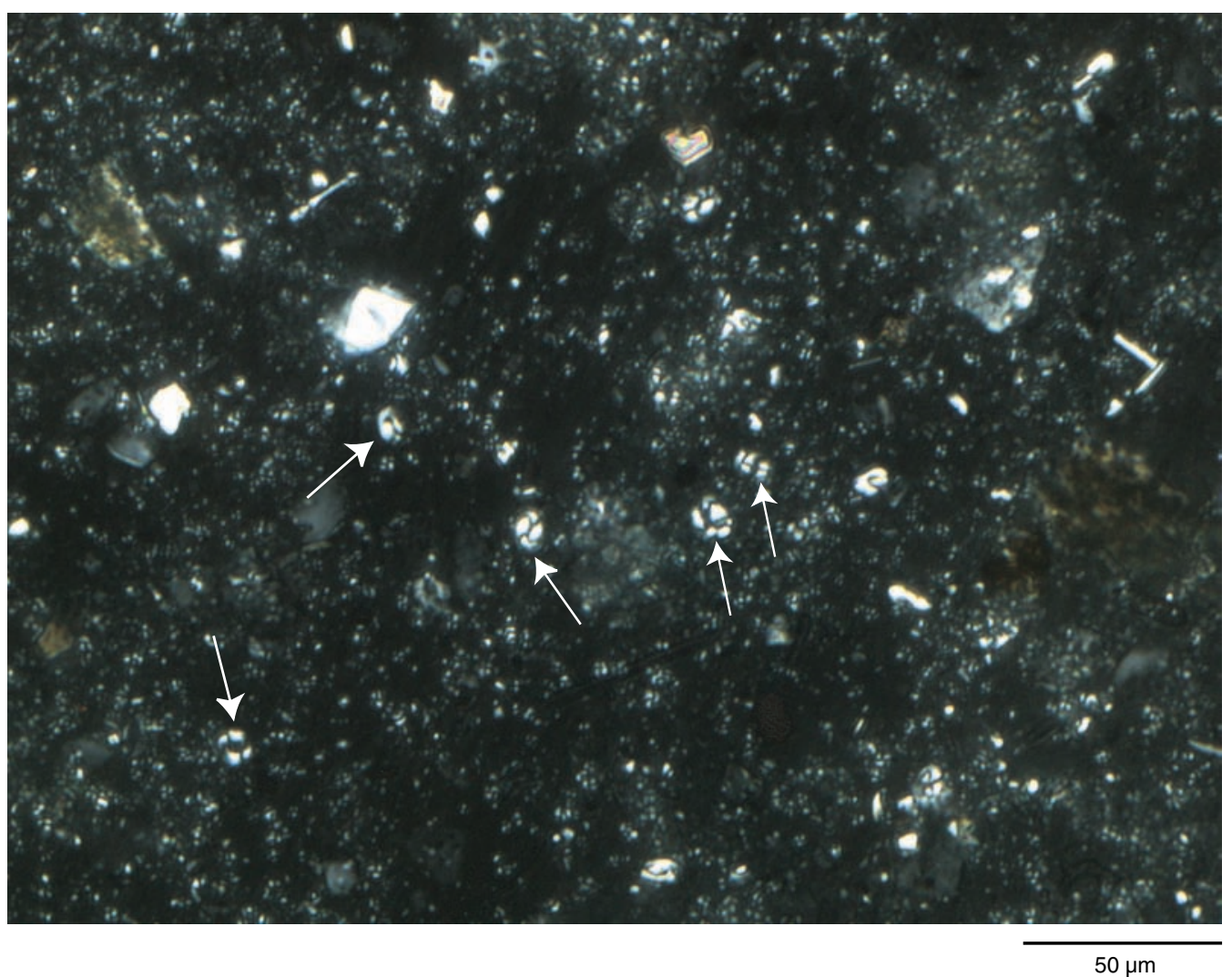


Figure F18. Soupy and mousselike sediment textures related to the presence of gas hydrate in dark gray silty clay and dark greenish gray diatom clayey silt in lithostratigraphic Unit III (interval 311-U1325B-16X-1, 66$100 \mathrm{~cm}$ ). Because the photograph was taken one day after the core was split, the sediment has dried significantly. A soupy interval that was observed between 73 and $76 \mathrm{~cm}$ shortly after the core was split can no longer be observed.

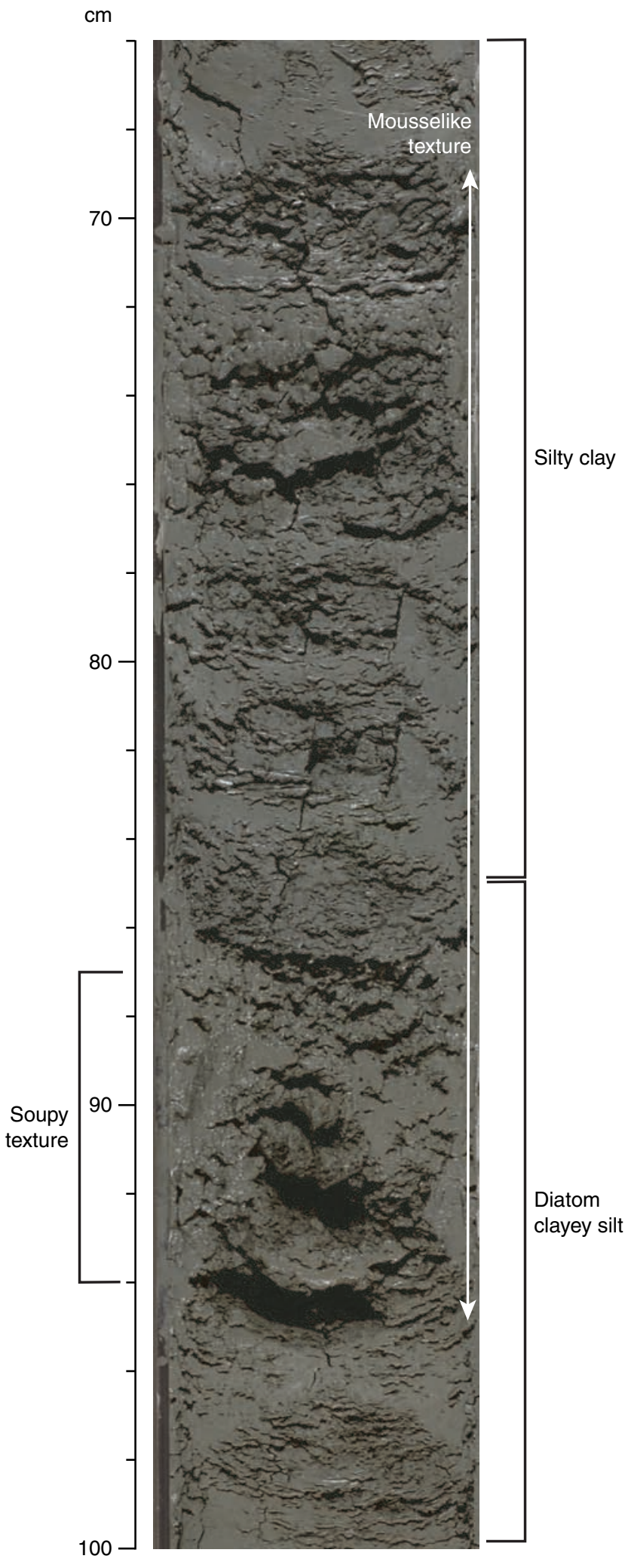


Figure F19. Sandy silt layer $(74-78 \mathrm{~cm})$ with a fining-upward sequence and sharp bottom contact within dark gray clay in lithostratigraphic Unit IV. The $72-78 \mathrm{~cm}$ interval is mousselike and corresponds to an IR camera anomaly (interval 311-U1325C-7X-3, 65-86 cm).

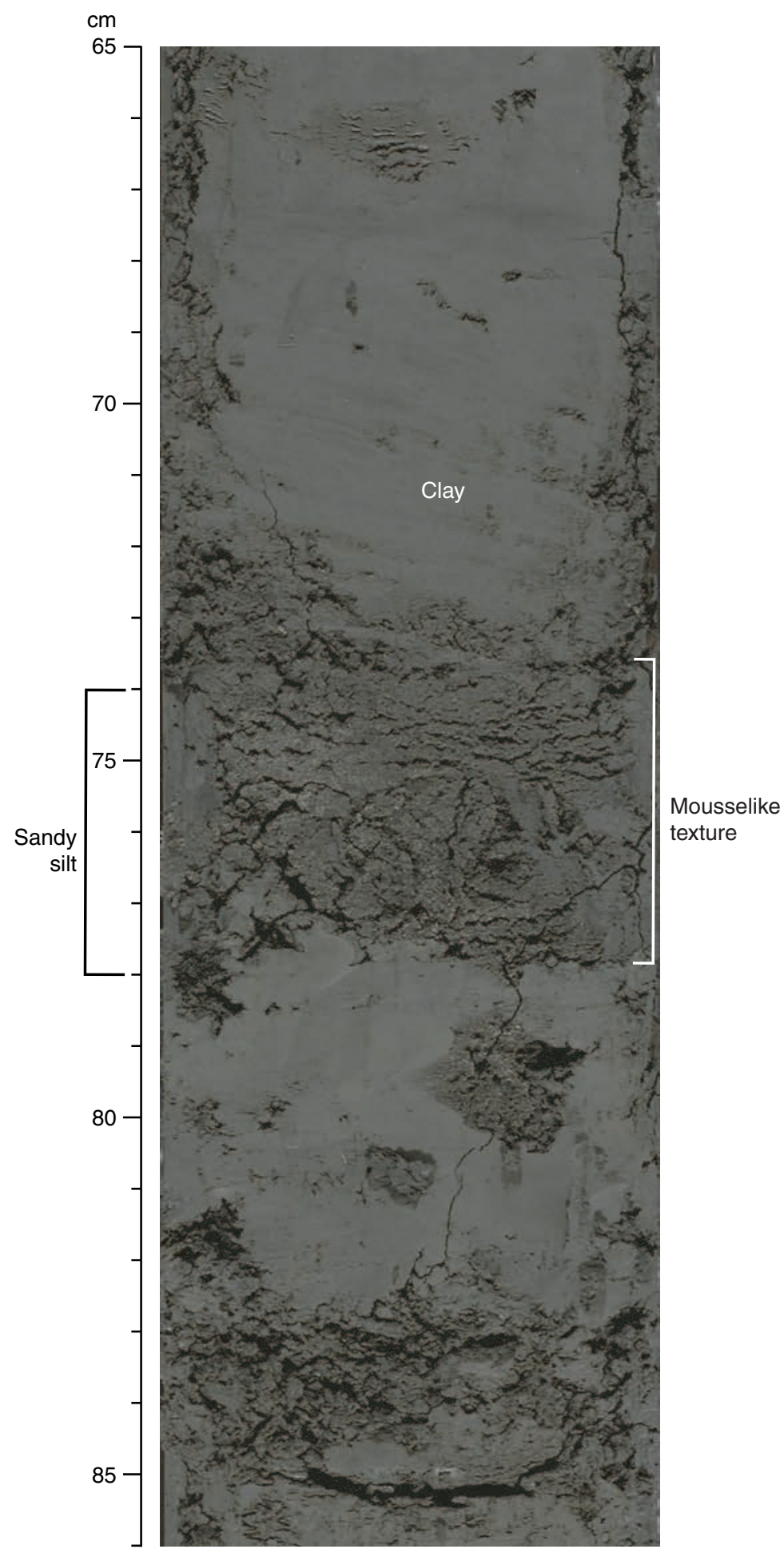


Figure F20. Small lithified round sulfide concretions within an iron sulfide mottling interval in lithostratigraphic Unit IV (interval 311-U1325C-8X-5, 118-131 cm).

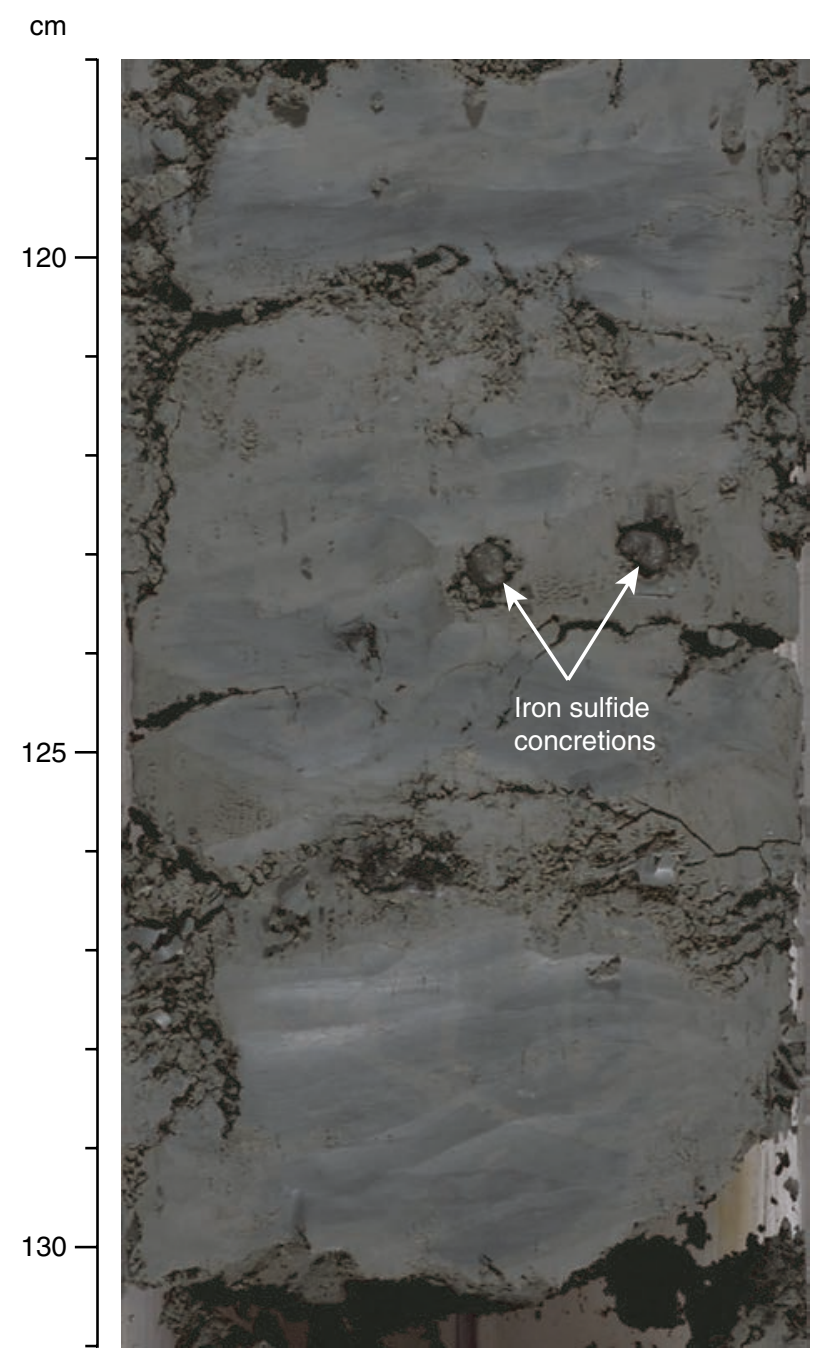


Figure F21. Well-preserved brittle star in lithostratigraphic Unit IV (interval 311-U1325C-15X-3, 60-65 cm).

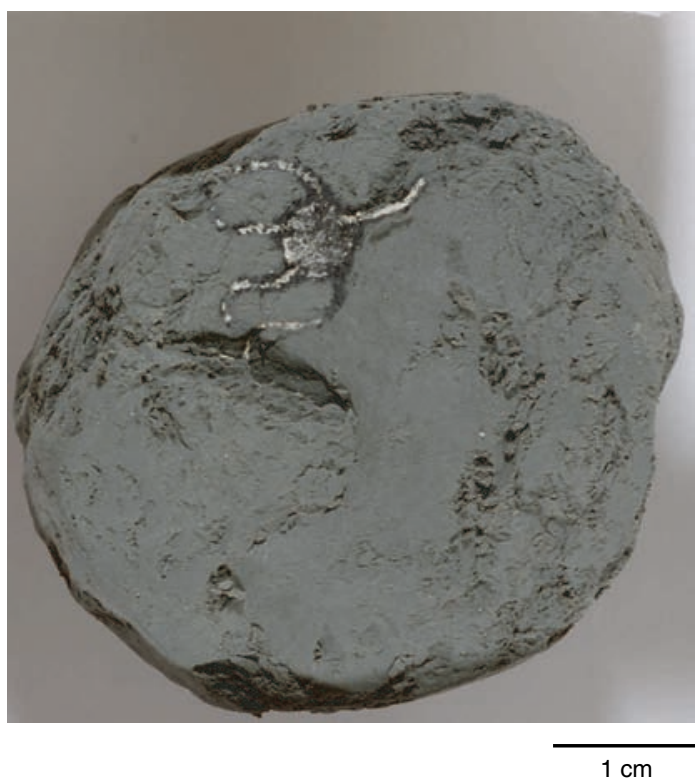


Figure F22. Mousselike texture related to the presence of gas hydrate within dark gray silty clay in lithostratigraphic Unit IV (interval 311-U1325C-8X-5, 78-97 cm).

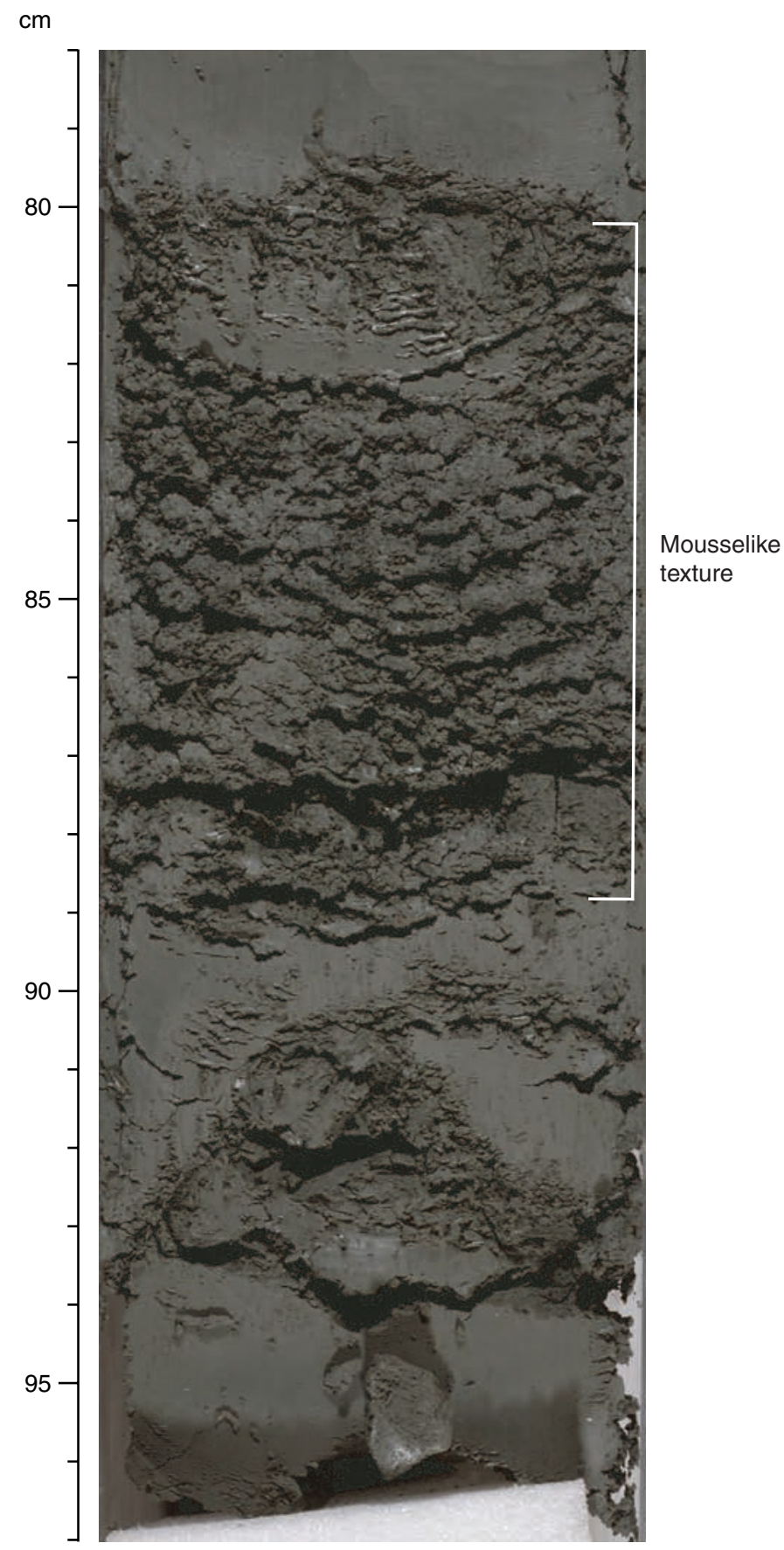


Figure F23. Concentration vs. depth profiles of salinity, dissolved chloride, sodium, and potassium in interstitial waters from Holes U1325B and U1325C. BW = bottom water, BSR = seismically inferred bottom-simulating reflector.
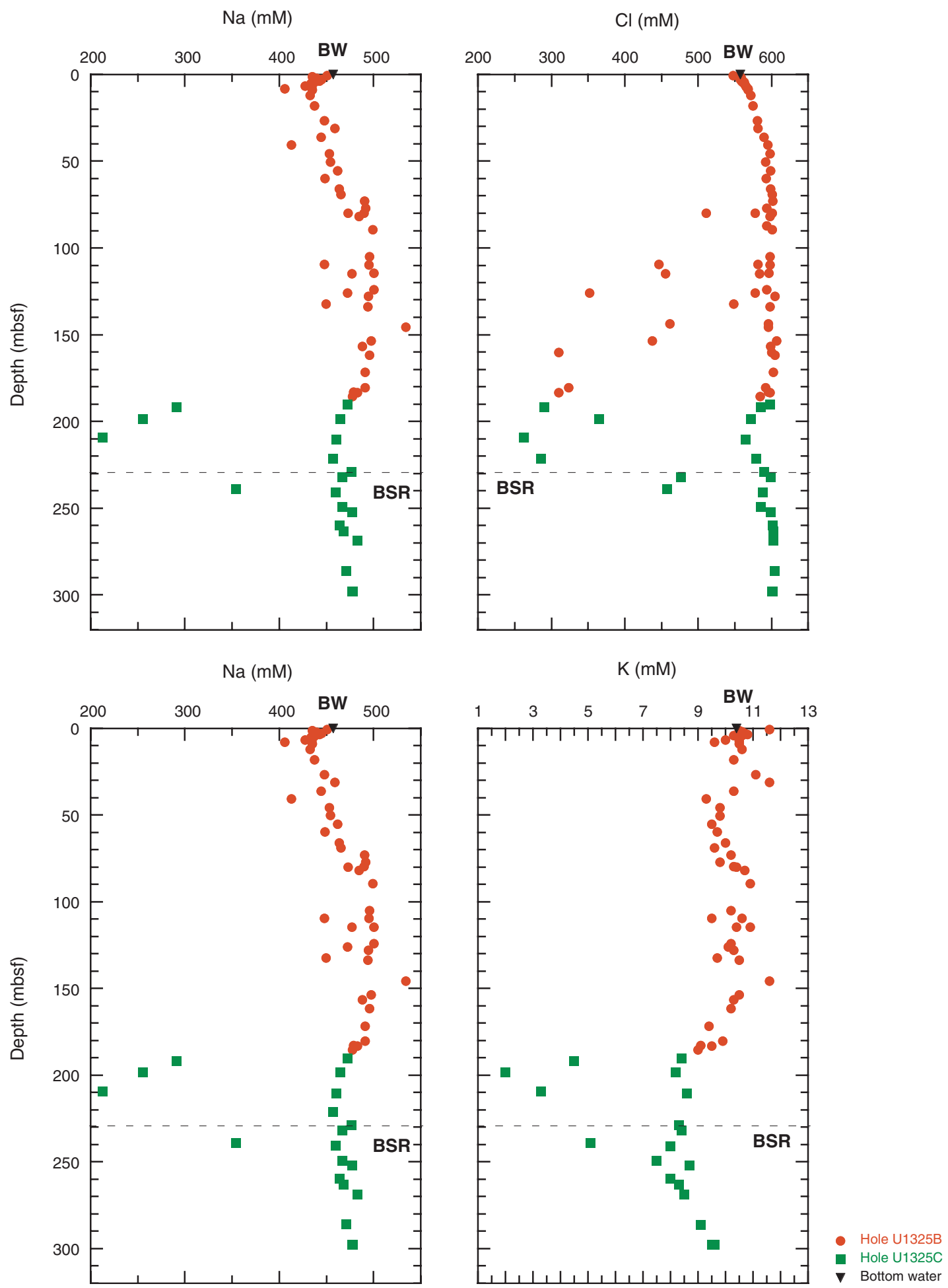
Figure F24. Concentration vs. depth profiles of alkalinity, sulfate, ammonium, and phosphate in interstitial waters from Holes U1325B and U1325C. BW = bottom water, BSR = seismically inferred bottom-simulating reflector.
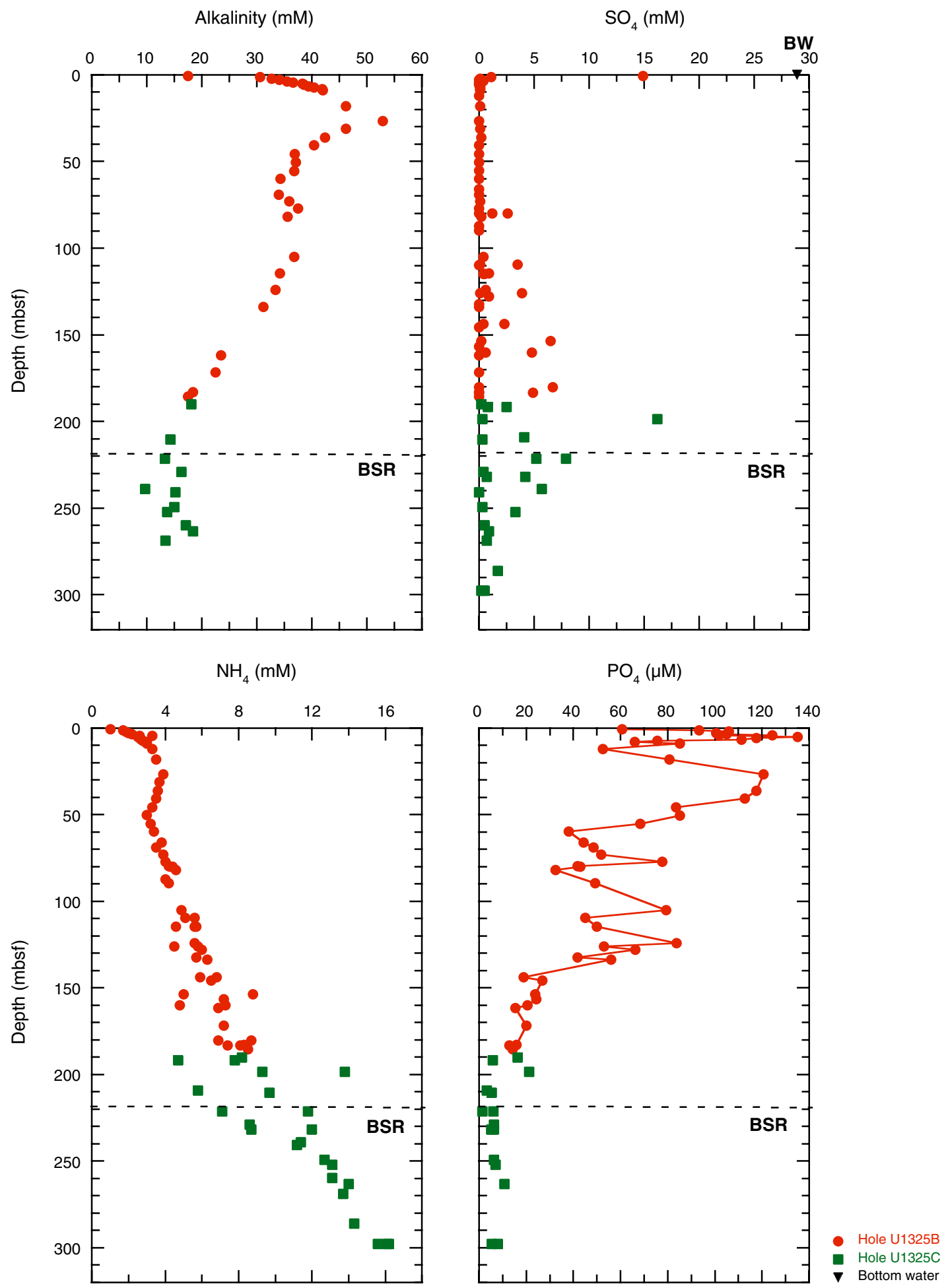
Figure F25. Concentration vs. depth profiles of dissolved calcium, magnesium, $\mathrm{Mg} / \mathrm{Ca}$ ratios, and strontium in interstitial waters from Holes U1325B and U1325C. BW = bottom water, BSR = seismically inferred bottomsimulating reflector.
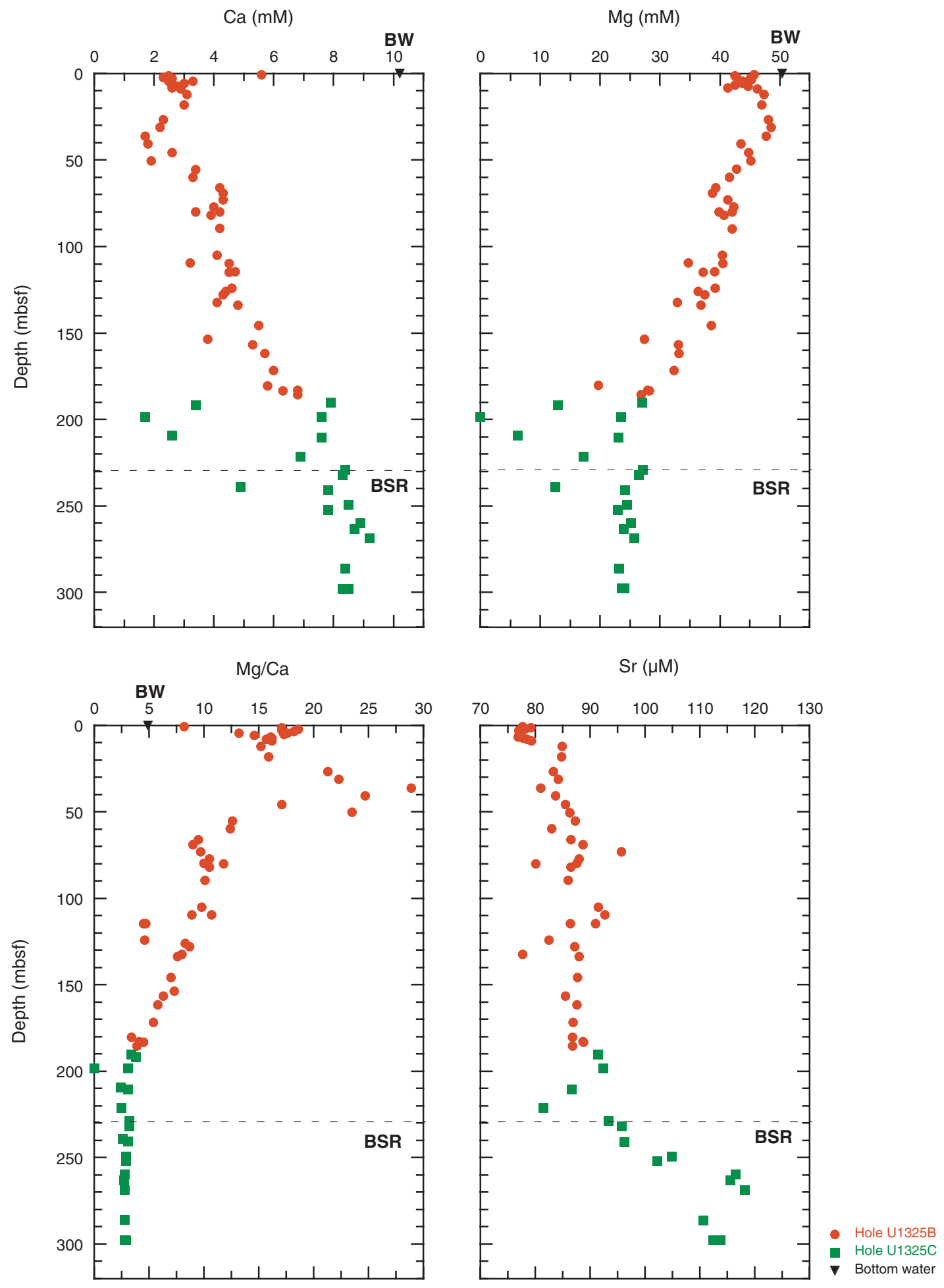
Figure F26. Concentration vs. depth profiles of dissolved silica, boron, and barium in interstitial waters from Holes U1325B and U1325C. BW = bottom water, BSR = seismically inferred bottom-simulating reflector.
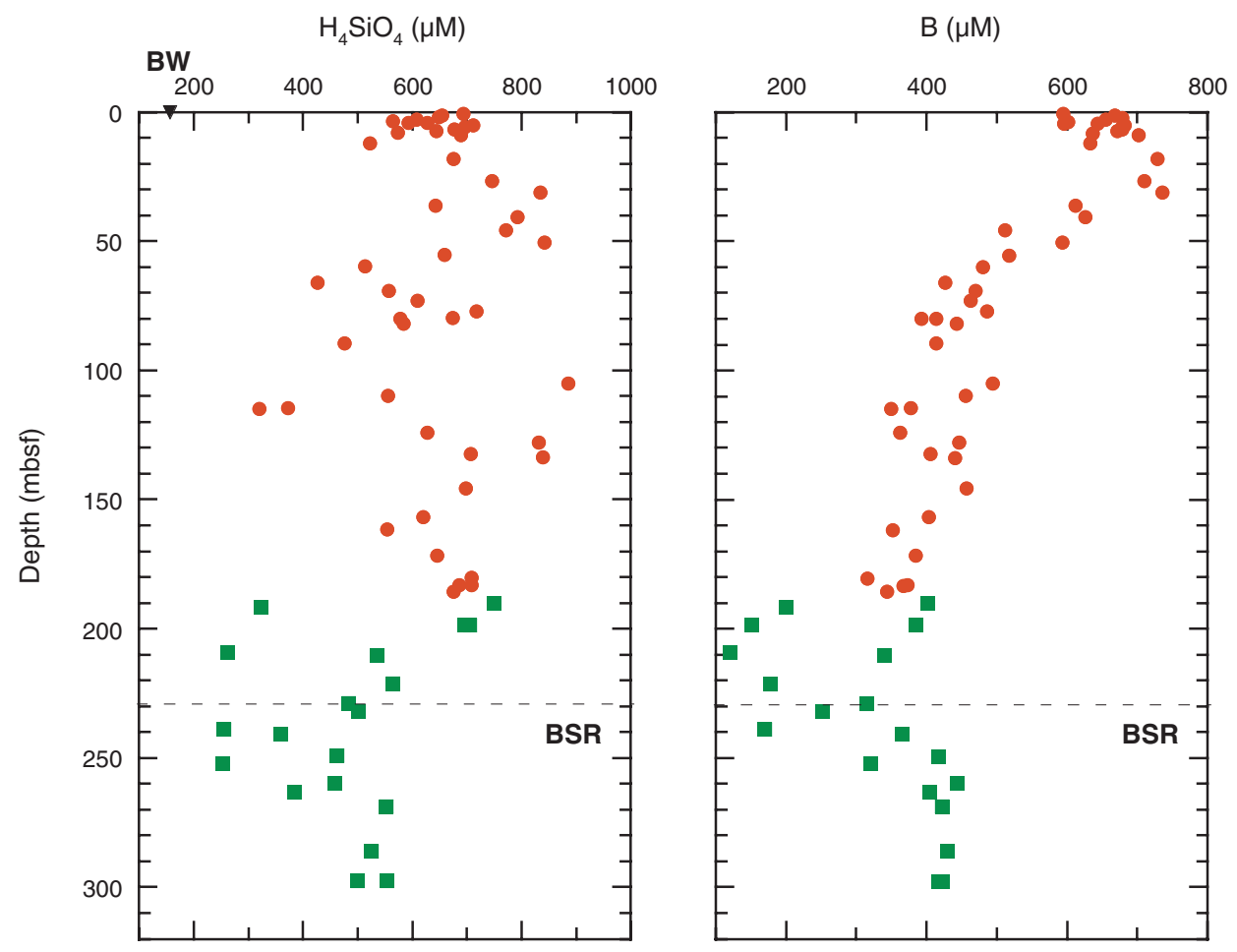

$\mathrm{Ba}(\mu \mathrm{M})$

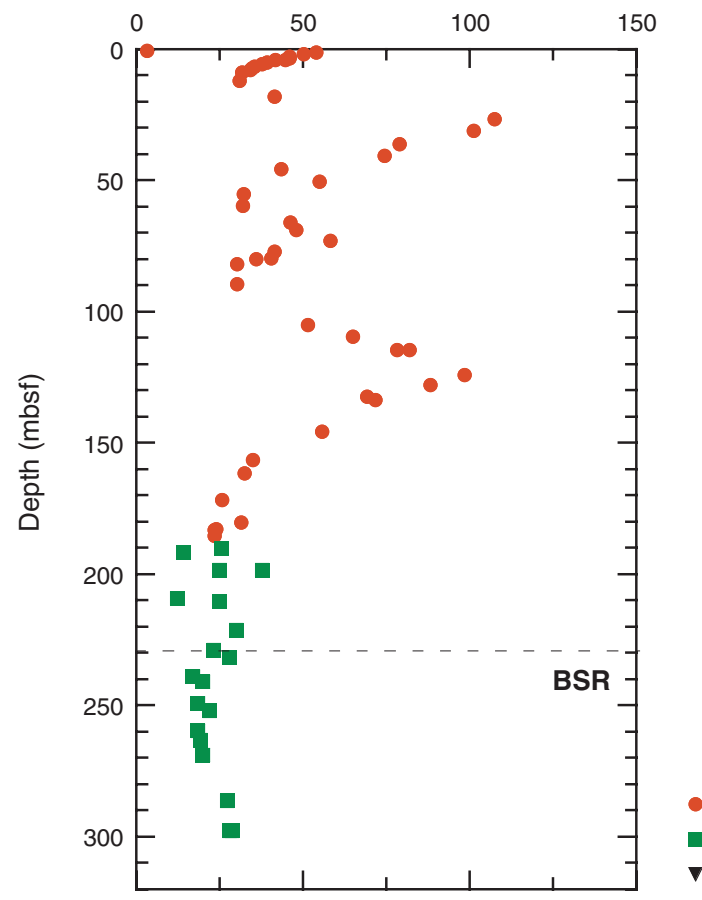


Figure F27. Sulfate profiles for the upper $6 \mathrm{~m}$ of Holes U1325B and U1325D, showing the estimated depth of the sulfate/methane interface between 4 and $5 \mathrm{mbsf}$ based on data from Hole U1325D (solid line, green squares). Hole U1325B (dashed line, red circles) apparently missed the mudline by $\sim 3 \mathrm{~m}$. SW = seawater.

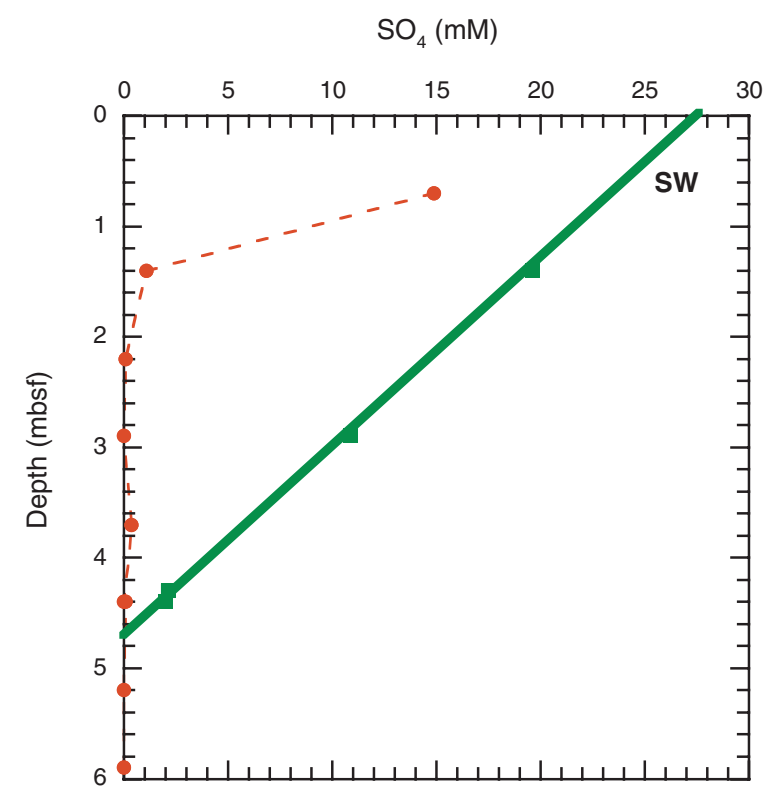


Figure F28. Concentrations of methane and ethane in headspace gas samples from Site U1325. BSR = bottomsimulating reflector.

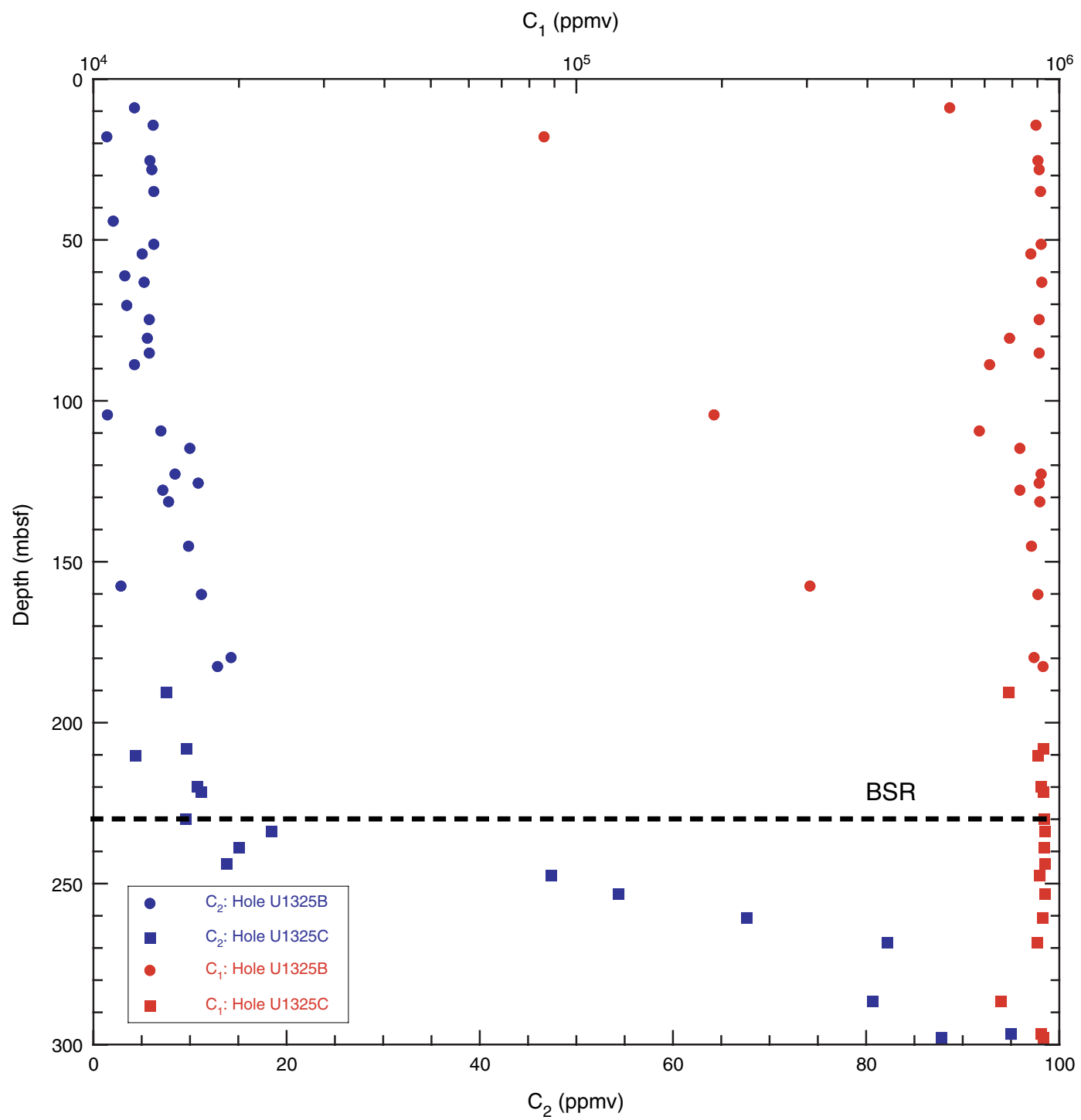


Figure F29. Concentrations of ethane, propane, $i$-butane, and $n$-butane in void gas samples from Site U1325. $\mathrm{BSR}=$ bottom-simulating reflector.

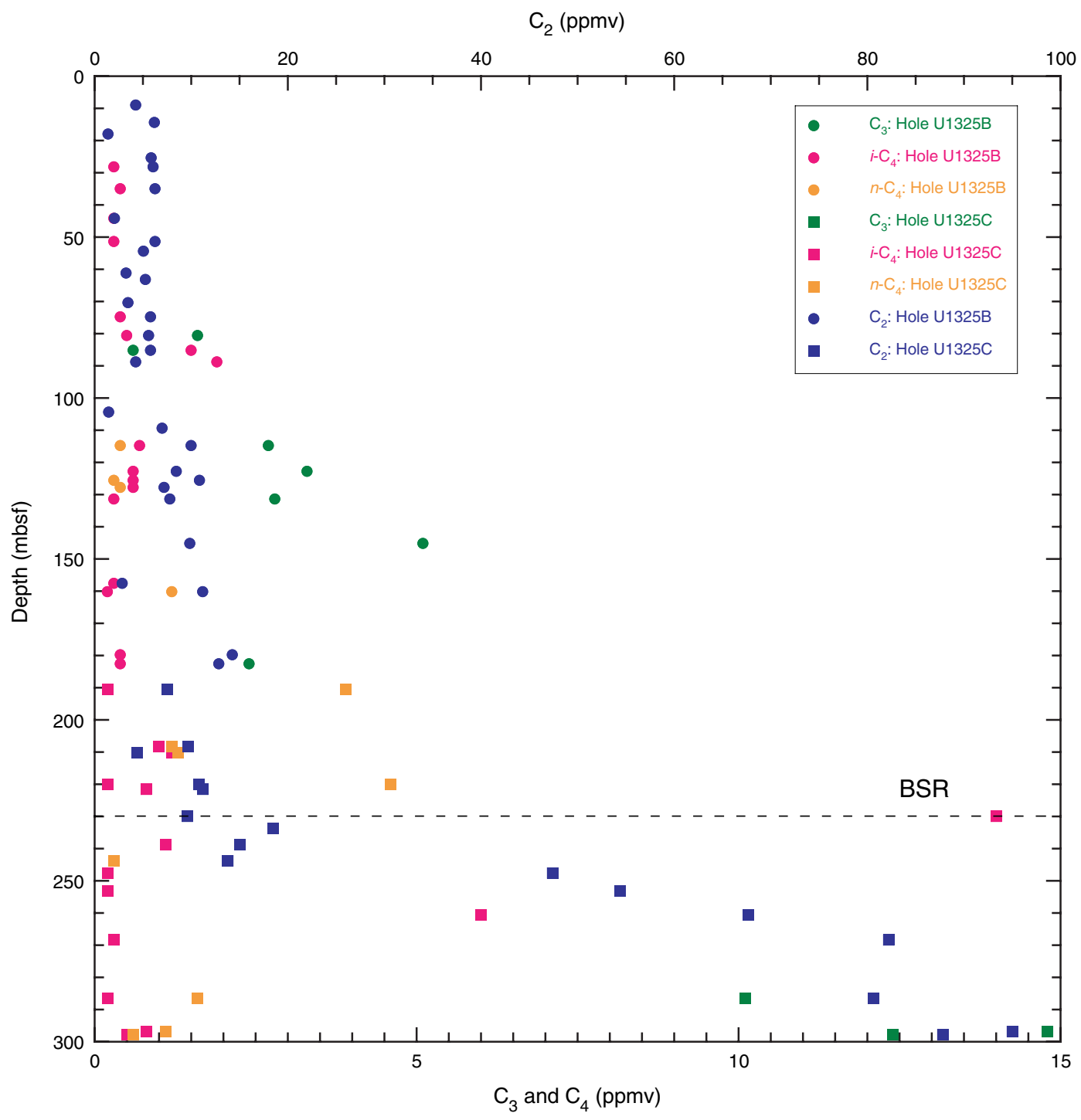


Figure F30. $\mathrm{C}_{1} / \mathrm{C}_{2}$ ratios in headspace (HS) and void gas (VAC) samples from Site U1325. BSR = bottom-simulating reflector.

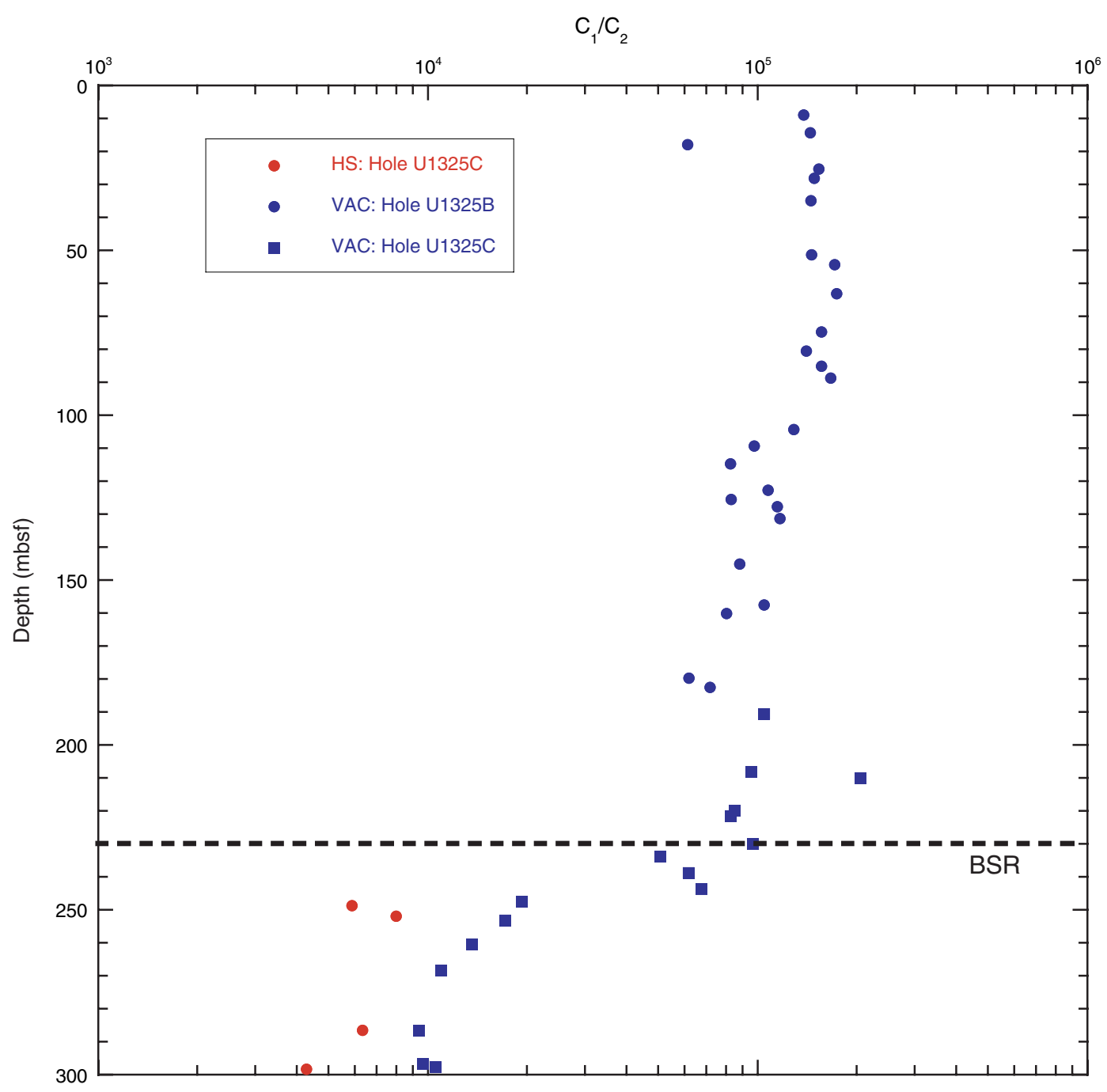


Figure F31. $\mathrm{C}_{1} / \mathrm{C}_{2}$ ratios vs. temperature at Site $\mathrm{U} 1325 . \mathrm{VAC}=$ void gas.

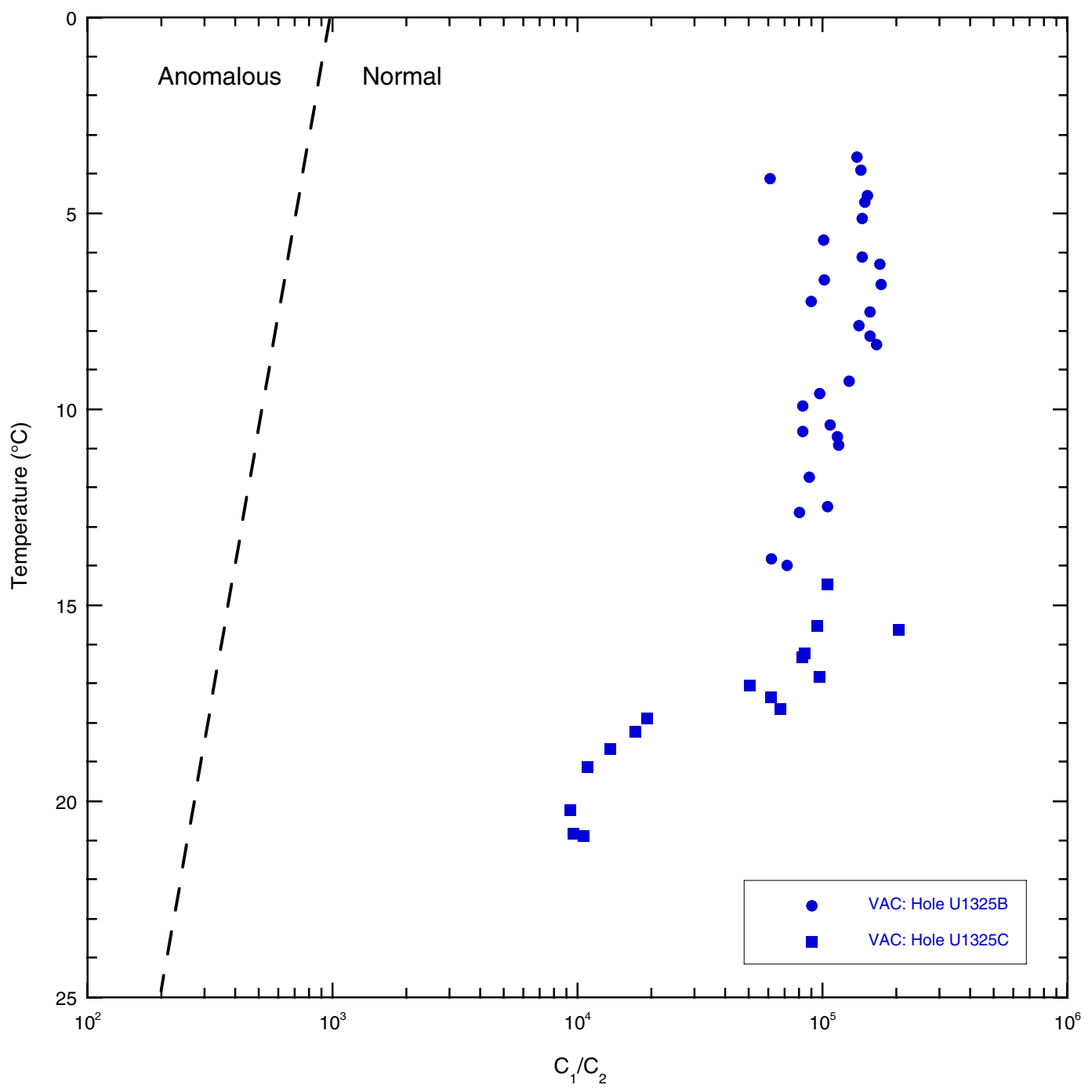


Figure F32. Dissolved sulfate and methane concentrations from Site U1325. The sulfate profile from Hole U1325D reflects the actual distribution of sulfate in the near-surface sediments. The sulfate/methane interface depth in Hole U1325B is most likely incorrect because Core 311-U1325B-1H missed the mudline.

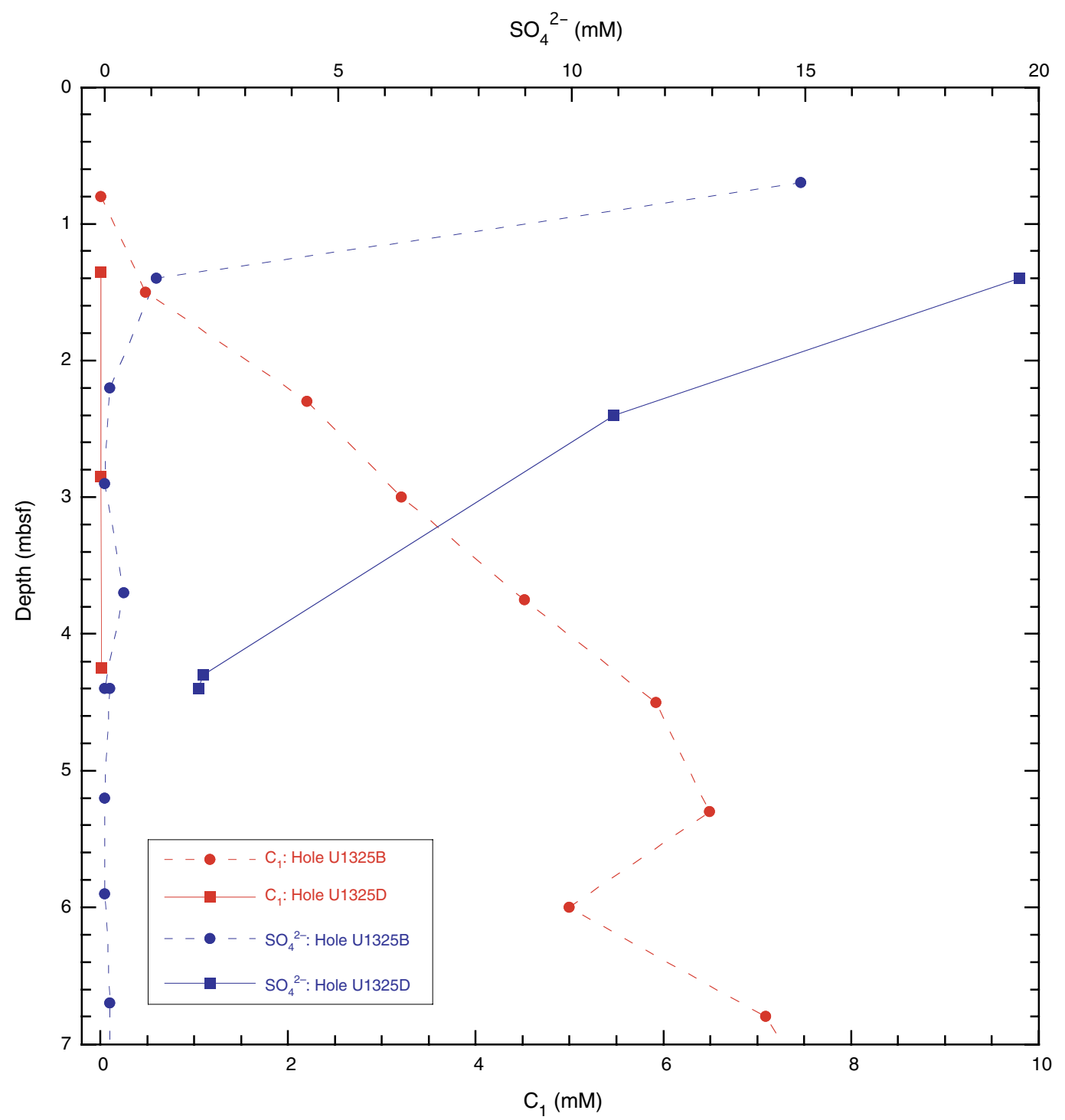


Figure F33. Contents of sediment inorganic carbon (IC), calcium carbonate, total organic carbon (TOC), total nitrogen (TN), and C/N ratios from Site U1325.
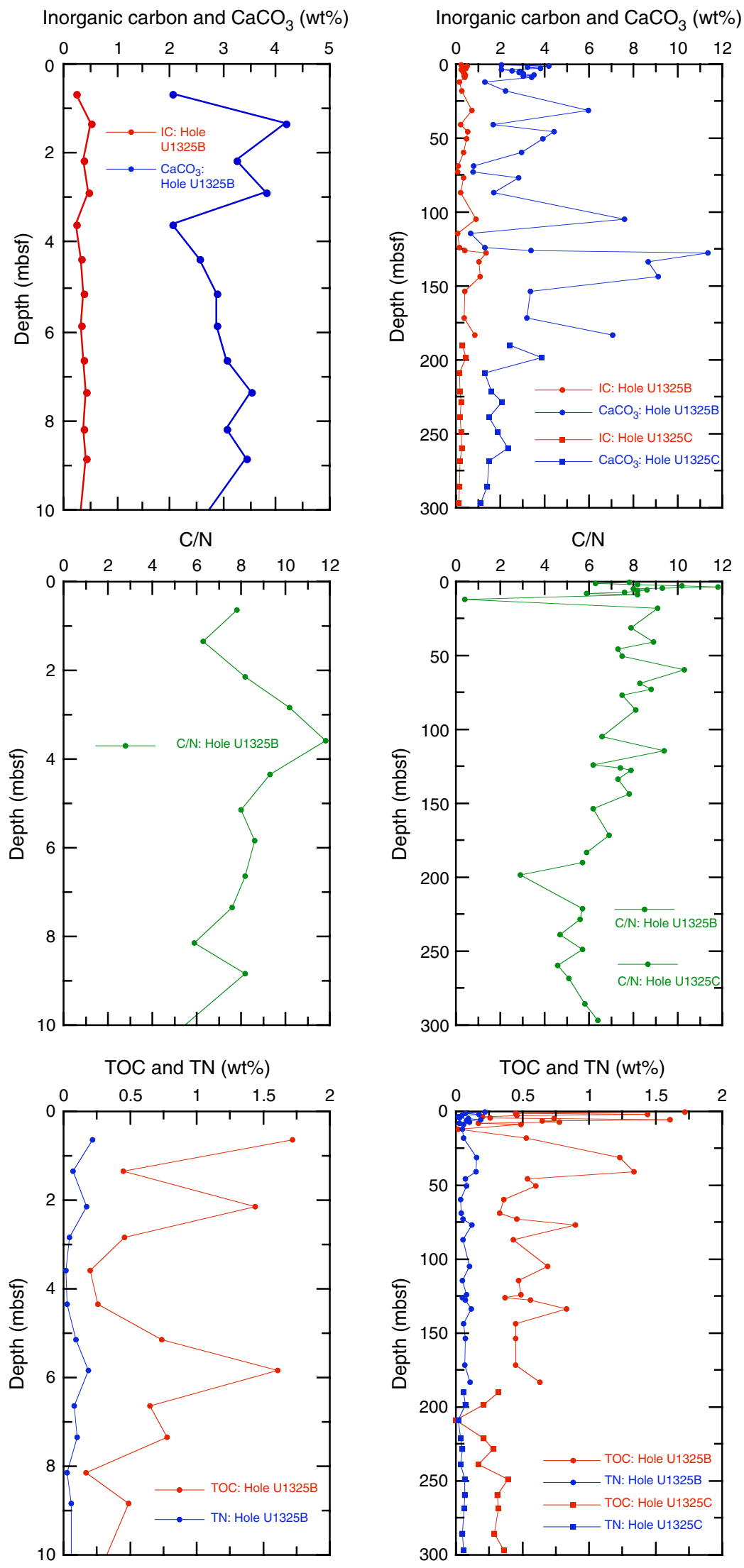
Figure F34. Overview of physical property data from Site U1325. Line in thermal conductivity column shows regional trend from Davis et al., 1990. $\mathrm{LWD}=$ logging while drilling, MAD = moisture and density, MST = multisensor track, AVS = automated vane shear, BSR $=$ bottom-simulating reflector.
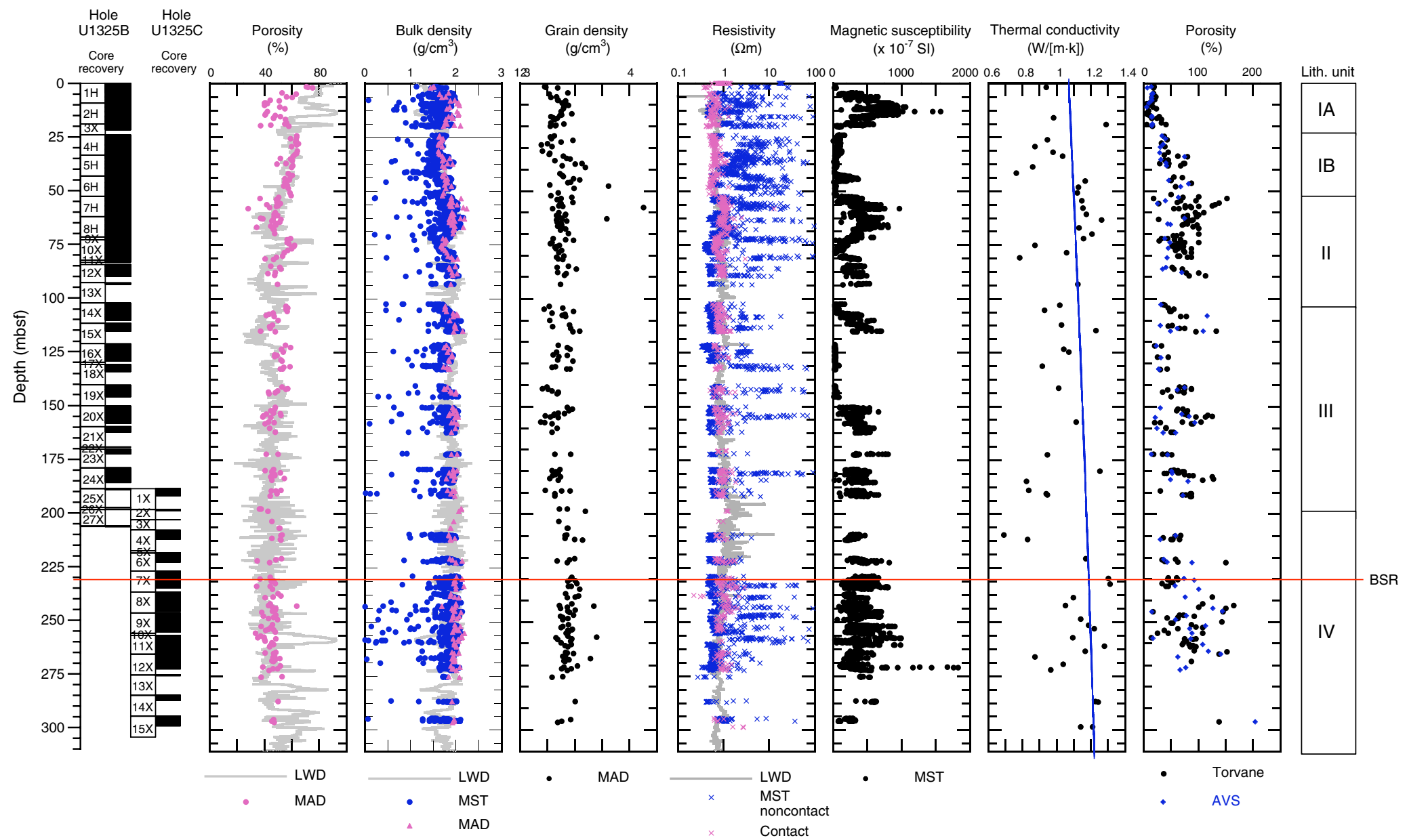
Figure F35. Combined infrared (IR) images of core liner temperature from Holes U1325B and U1325C compared to logging-while-drilling/measurement-while-drilling (LWD/MWD) resistivity and calculated pore water saturation from Hole U1325A. Core recovery and handling time are also shown. BSR = bottom-simulating reflector. (This figure is also available in an oversized format.)

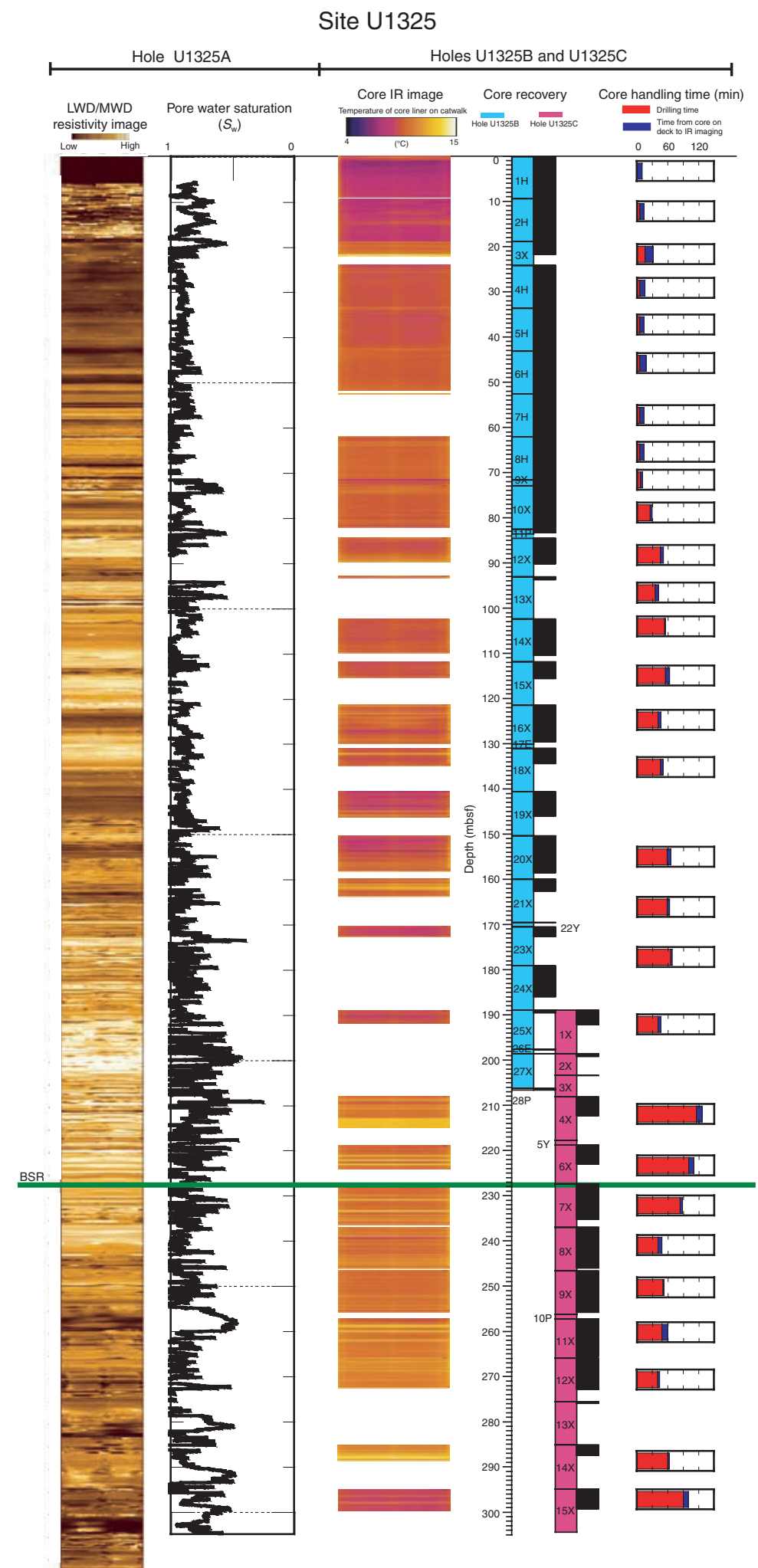


Figure F36. A. Downhole temperature in Holes U1325B and U1325C based on concatenation of core liner temperatures averaged across each pixel row (see text for details). B. Core liner temperature profile for Core 311-U1325C-4X. The local no-gas-hydrate, no-void baseline is clear, along with a cold anomaly interpreted to have been caused by gas hydrate dissociation and several warm anomalies caused by voids. C. IR image of Core 311-U1325C-4X. D. Pore water saturation calculated from LWD resistivity data for 205-215 mbsf in Hole U1325A.

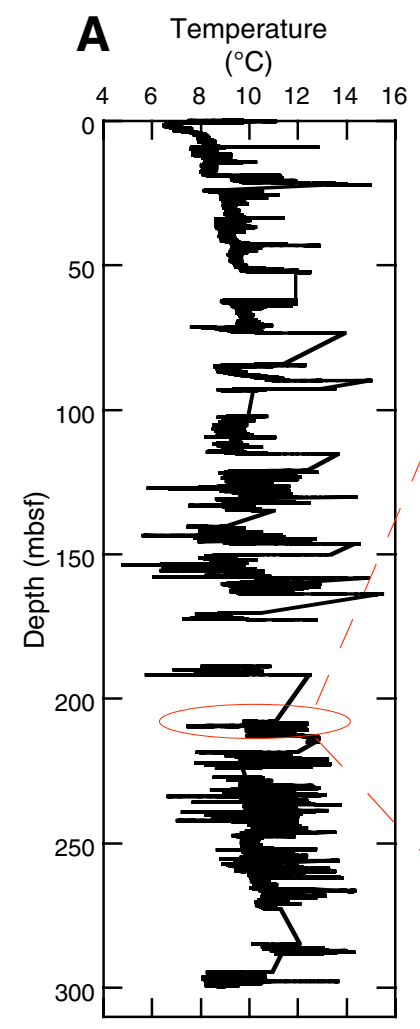

B Temperature $\left({ }^{\circ} \mathrm{C}\right)$

D Pore water saturation $\left(S_{\mathrm{w}}\right)$
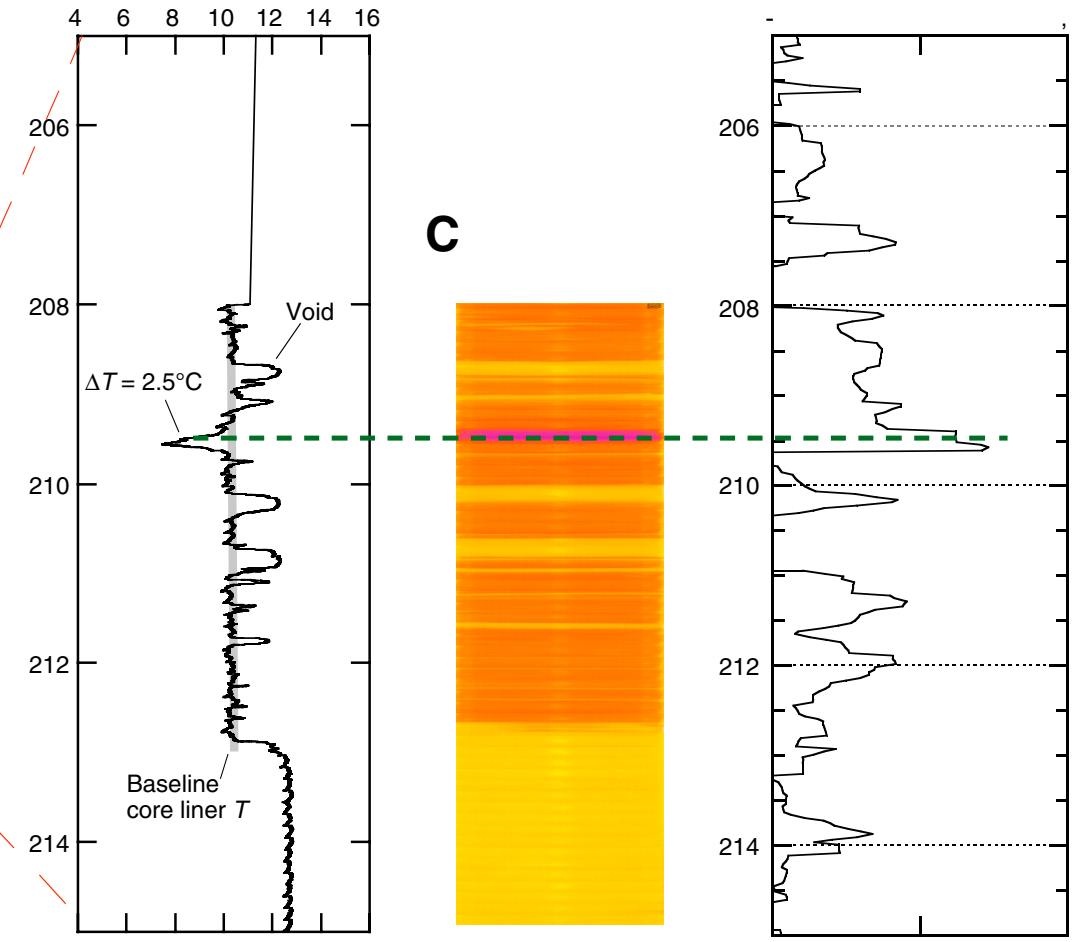
Figure F37. A. Interstitial water Sample 311-U1325B-4X-5, 125-133 cm. B. IR image and temperature profile (white line) location in the same sample. C. Temperature record along the profile shown in B.

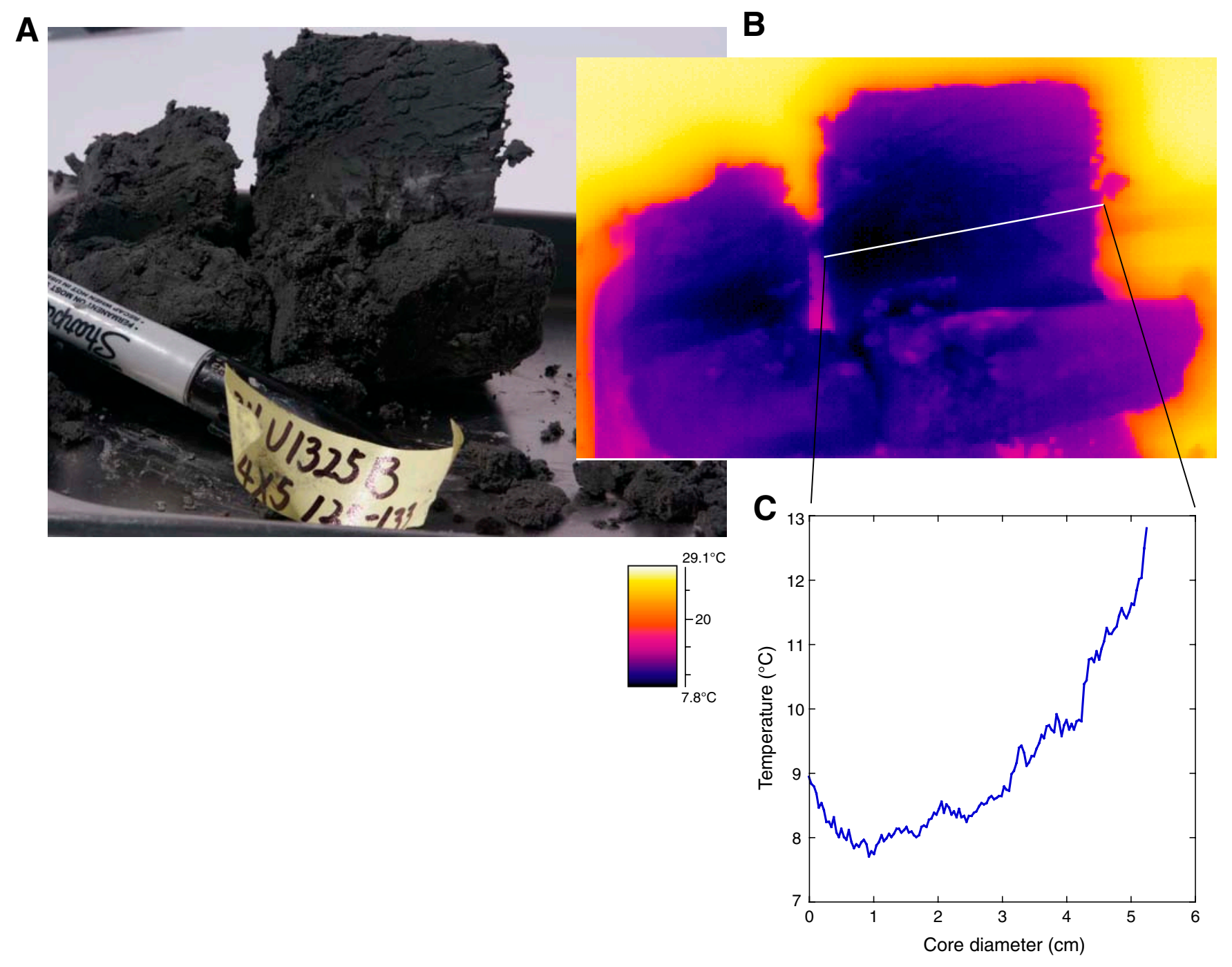


Figure F38. Comparison of Hole U1325B physical property data (55-85 mbsf) with Hole U1325A LWD data. Thermal conductivity is compared to the regional trend (vertical line) defined by Davis et al. (1990). LWD = logging while drilling, MAD = moisture and density, MST $=$ multisensor track.
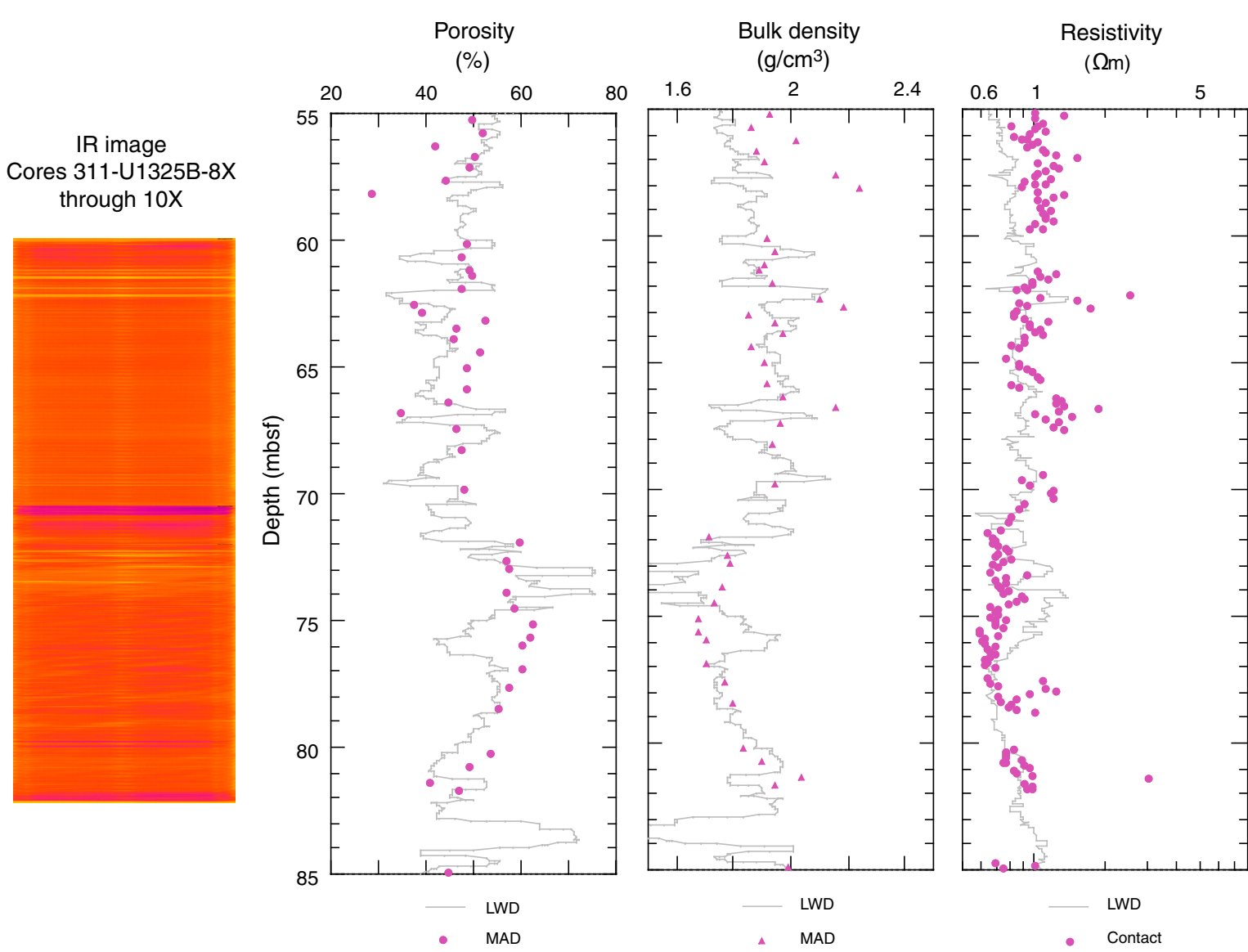

Magnetic susceptibility

$$
\left(\mathrm{x} 10^{-7} \mathrm{SI}\right)
$$

Thermal conductivity

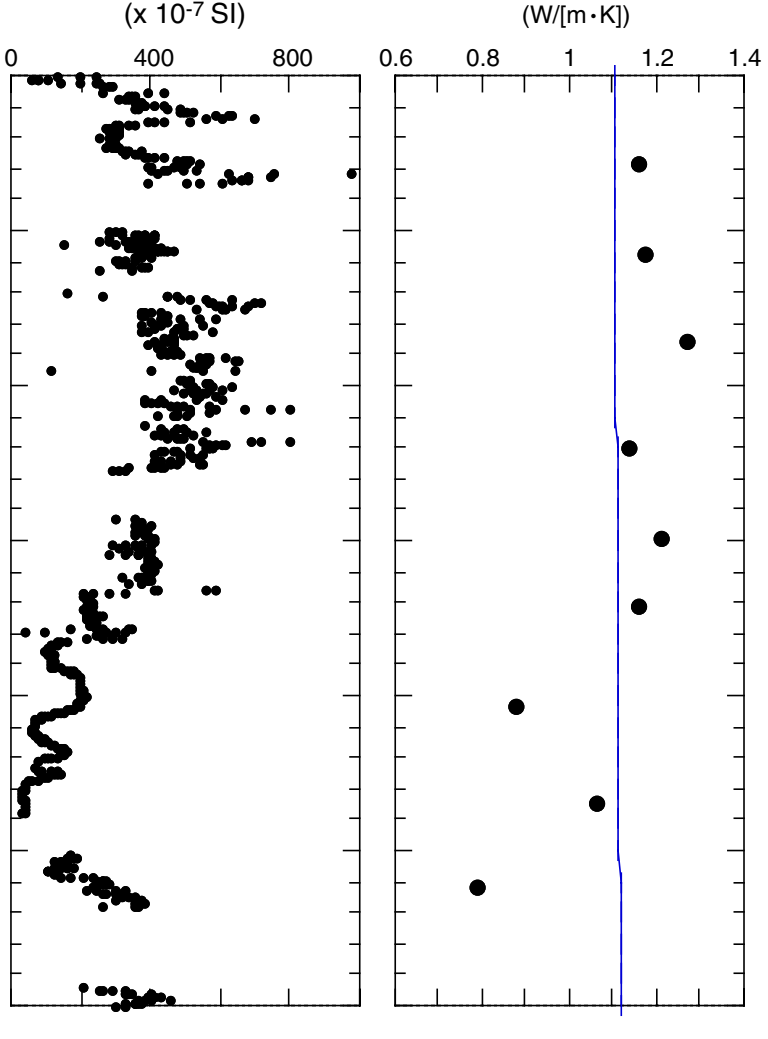

- MST

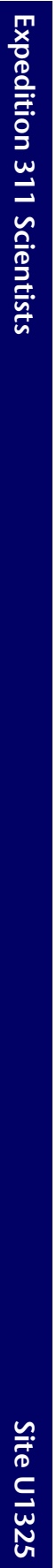


Figure F39. Porosity derived from MAD measurements at Sites U1325-U1329.

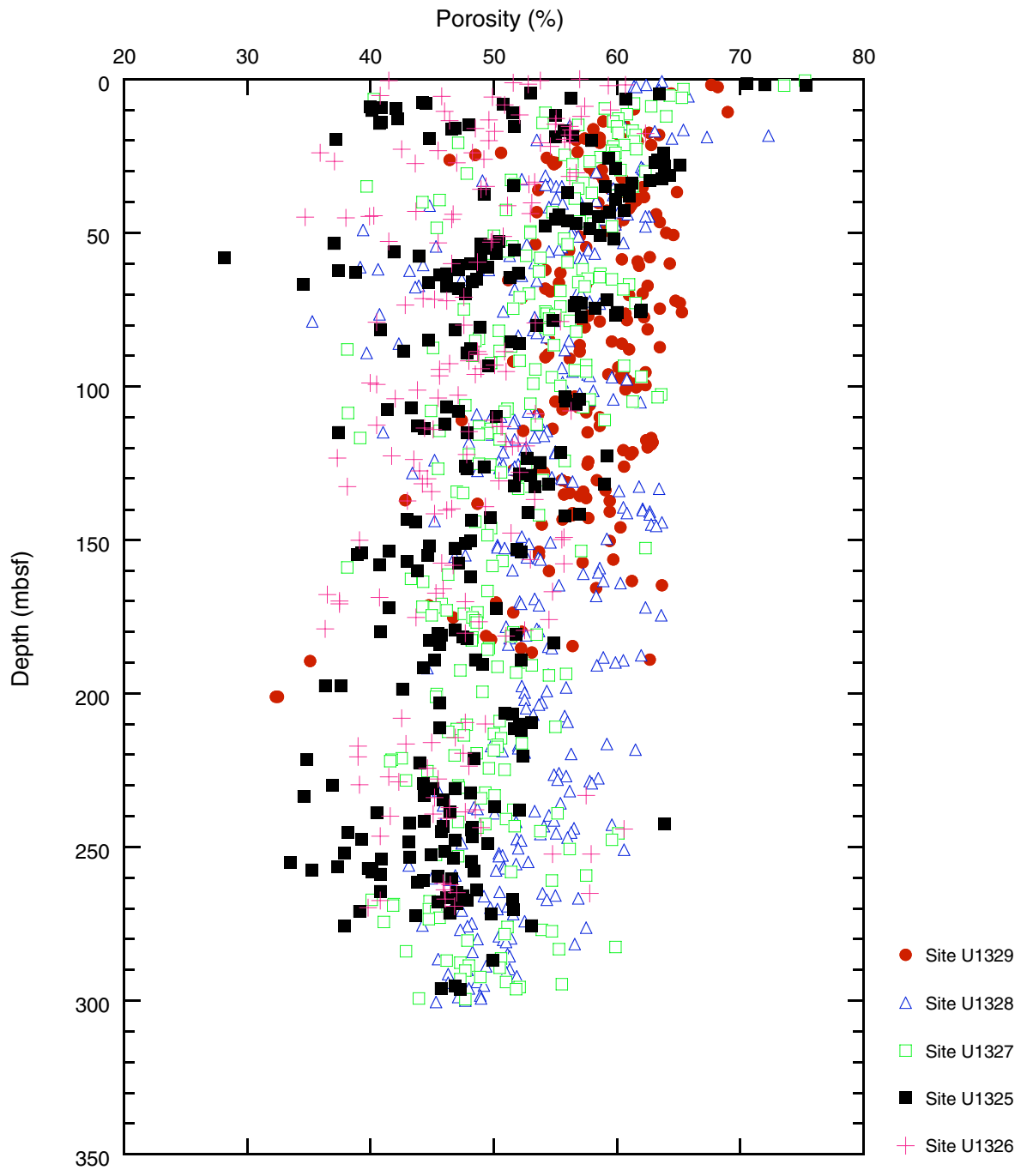


Figure F40. $P$-wave velocity measurements from Hole U1325D. A. Multisensor track (MST). B. Hamilton frame. PWS $=P$-wave sensor.

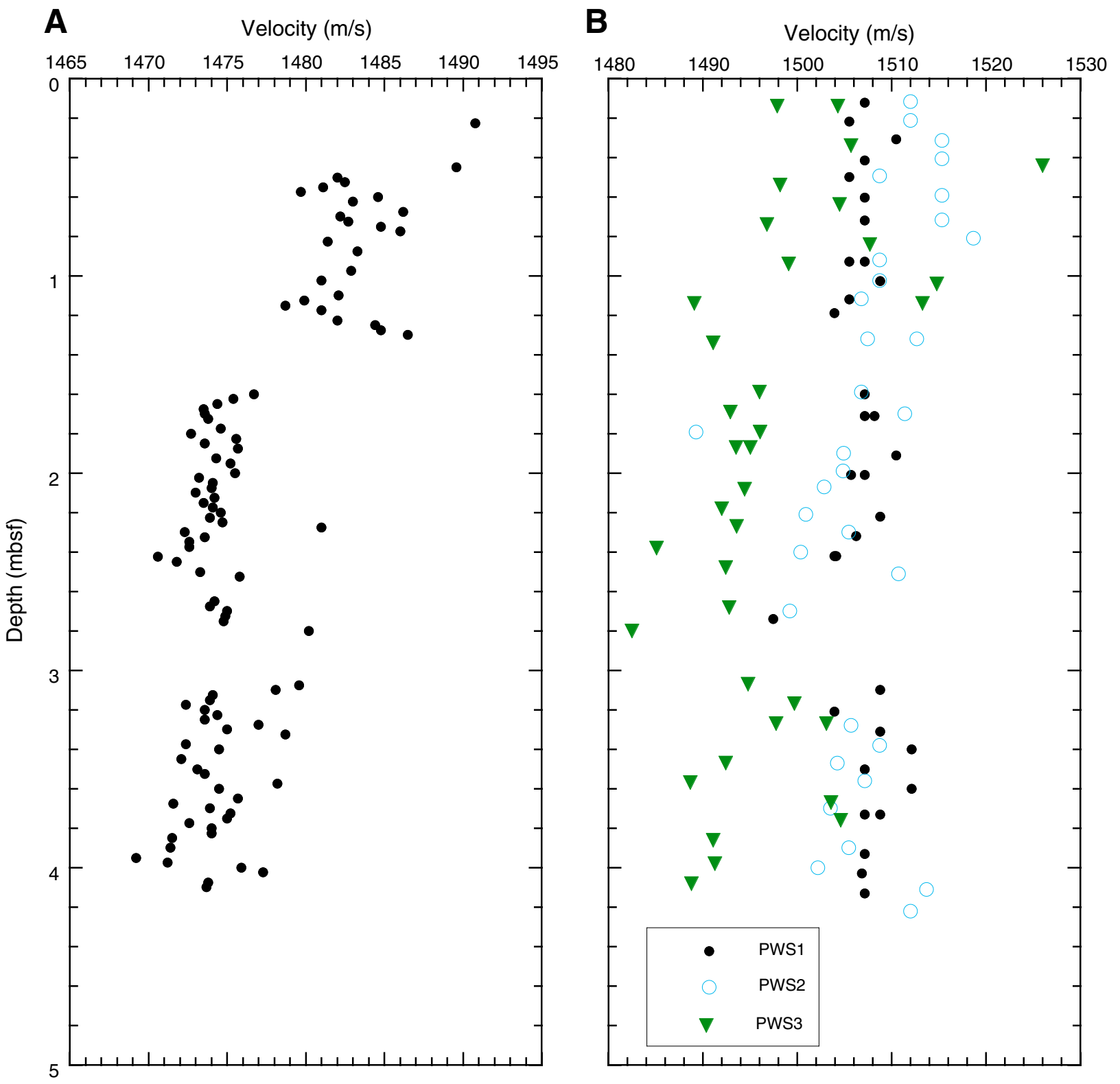


Figure F41. A. Comparison between automated vane shear (AVS) and handheld Torvane shear strength measurements. B. Overburden pressure calculated from MAD bulk density data. C. Ratio of shear strength to overburden pressure. This provides information on the degree of sediment underconsolidation or overconsolidation.

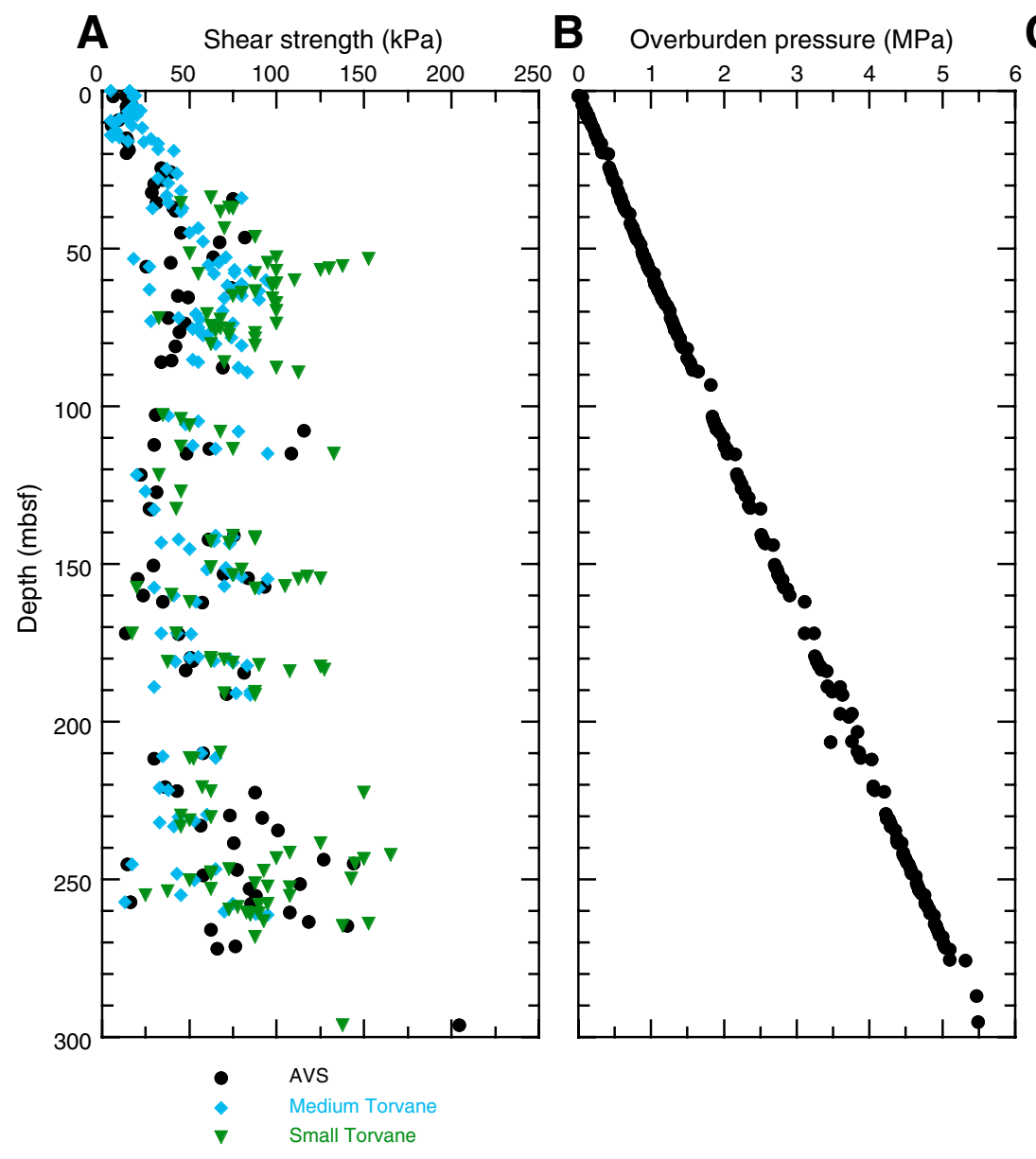

C Shear strength/Overburden pressure

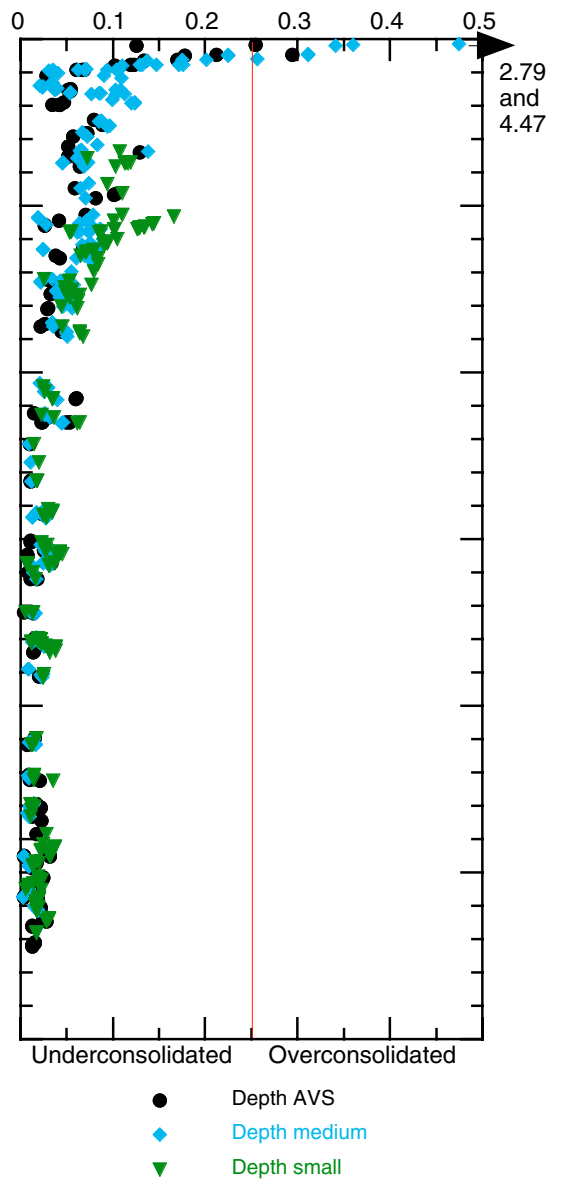


Figure F42. A. Comparison of pore water resistivity calculated from interstitial water salinity, using equations developed by Fofonoff (1985), and bulk volume contact resistivity of sediments from Site U1325. Both sets of values have been corrected to $20^{\circ} \mathrm{C}$. B. Formation factor (ratio of pore water resistivity to sediment resistivity). C. Comparison of porosity derived from moisture and density (MAD) measurements and Archie's equation. (Continued on next page.)
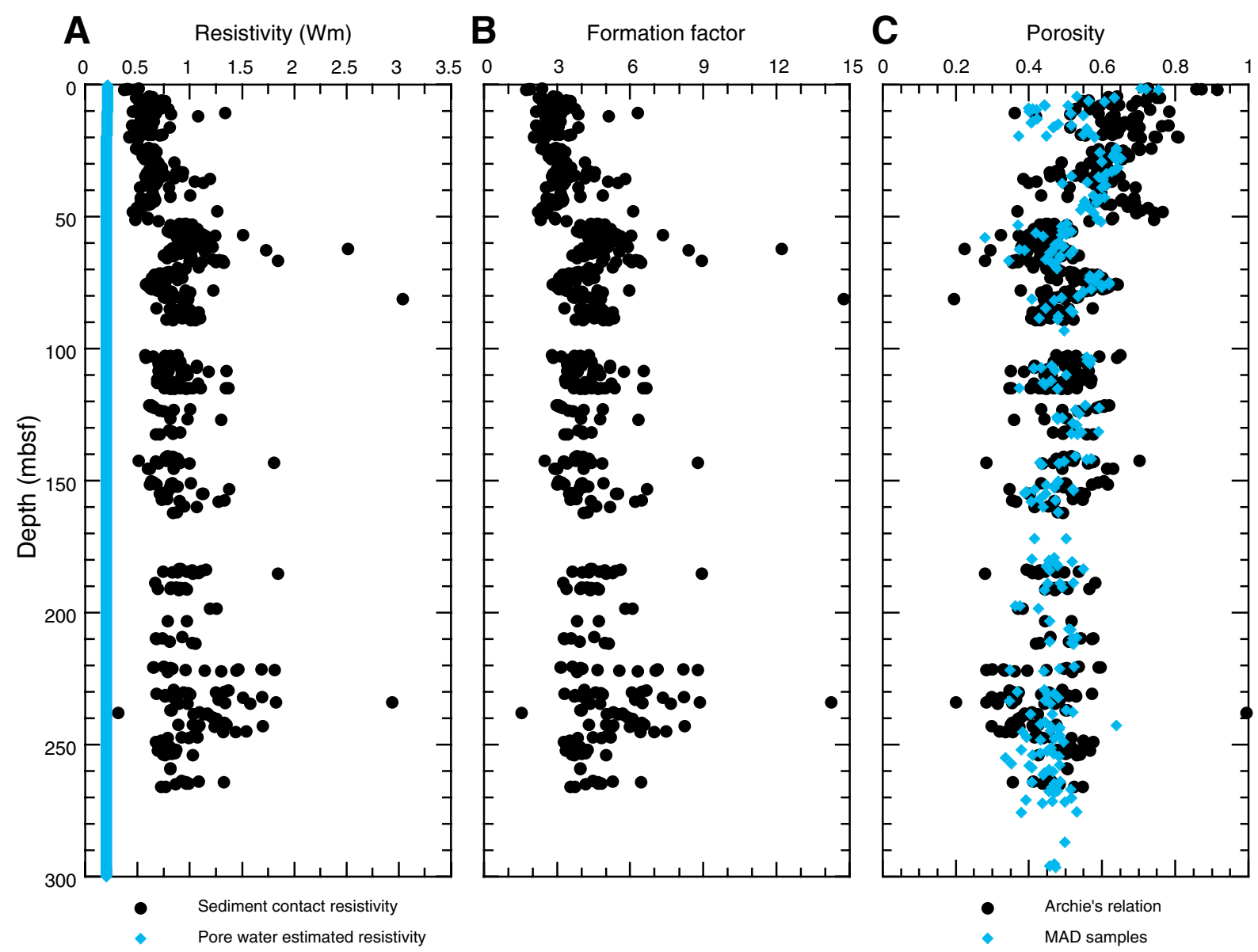
Figure F42 (continued). D. Formation factor vs. MAD porosity. Best-fit Archie's parameters were determined separately for sands (open circles) and clays (solid circles). Sediment lithology was identified based on visual observations made while taking MAD samples. Archie's parameters are $m=1.40$ and $a=1.53$ for clays and $m=$ 2.35 and $a=0.523$ for sands.

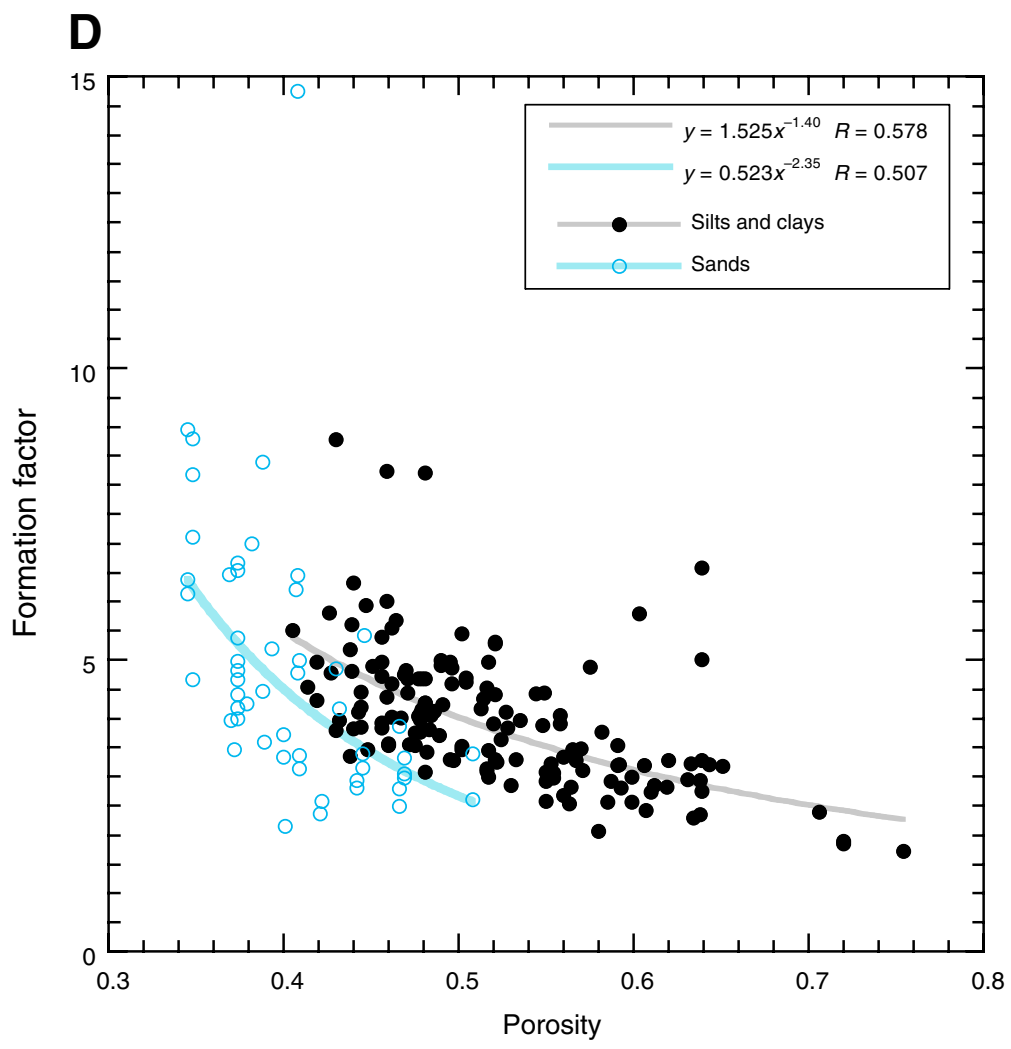


Figure F43. A. Third-generation advanced piston corer temperature (APCT-3; APC3 in figure) tool in situ temperature data from Hole U1325B. (Continued on next page.)
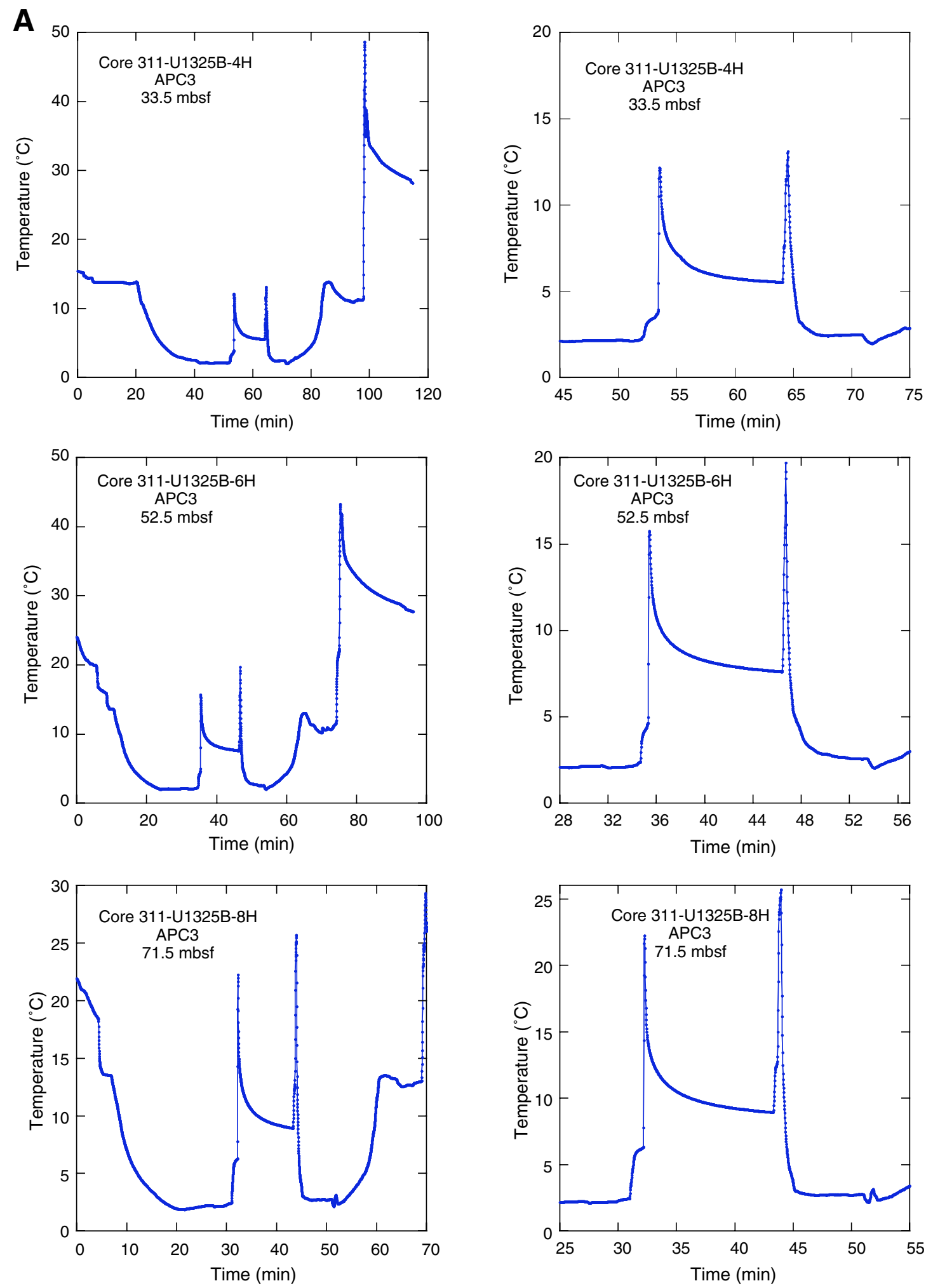
Figure F43 (continued). B. Davis-Villinger Temperature Probe (DVTP) in situ temperature data from Holes U1325B and U1325C. Both the upper (black line) and lower (blue line) thermistors are shown. The entire temperature record is shown as well as the portion of data used to estimate the in situ temperature.
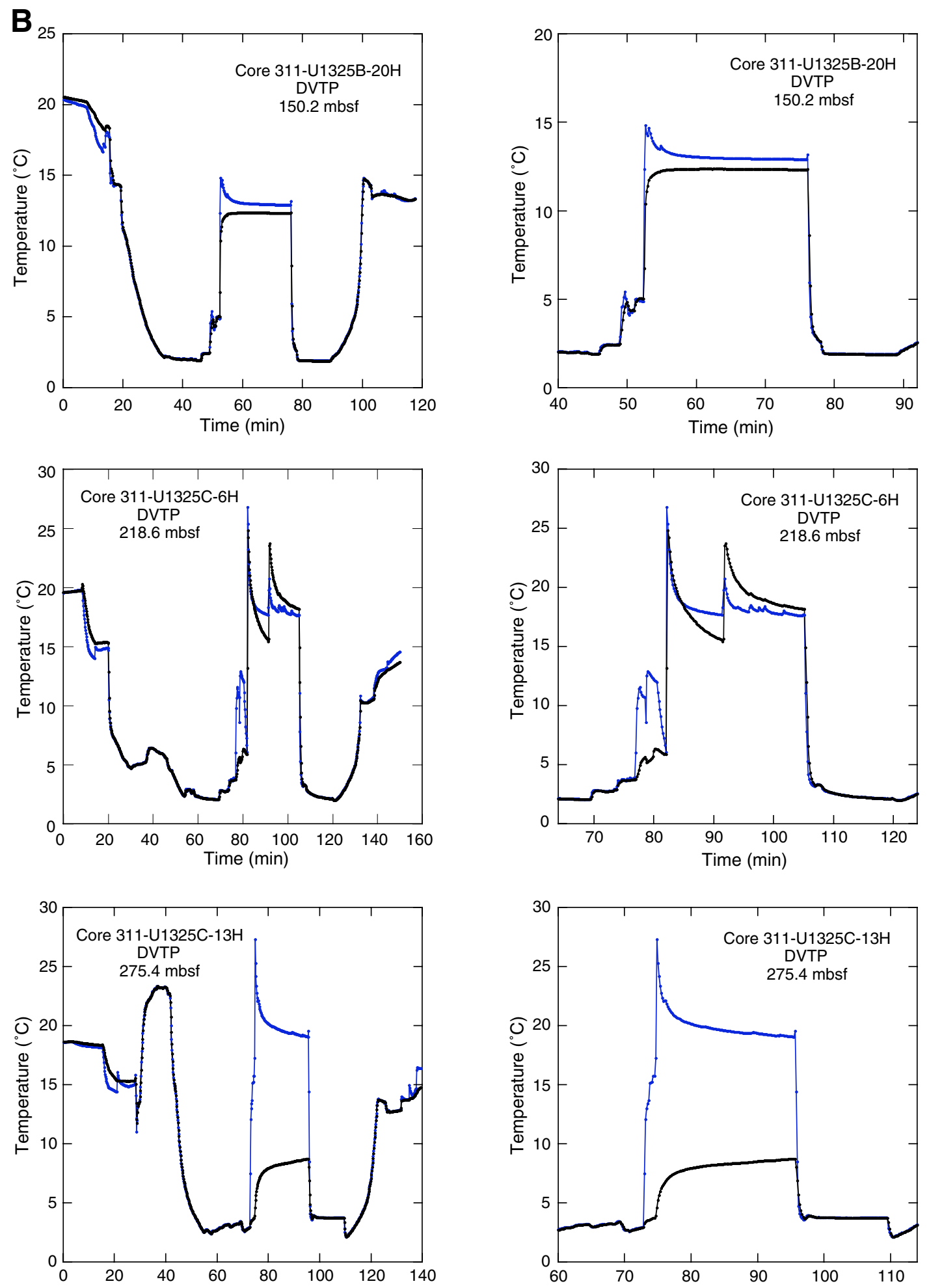
Figure F44. Apparent geothermal gradient at Site U1325. See text for further discussion of uncertainties. The stability boundary for gas hydrate at hydrostatic pressure is shown (calculated using CSMHY; Sloan, 1998) for the background salinity of pore water near the base of the gas hydrate stability zone (GHSZ) at this site, which was similar to seawater $(3.5 \% \mathrm{NaCl})$. The bottom-simulating reflector (BSR) is predicted from seismic data. The base of the GHSZ is predicted from the thermal gradient.

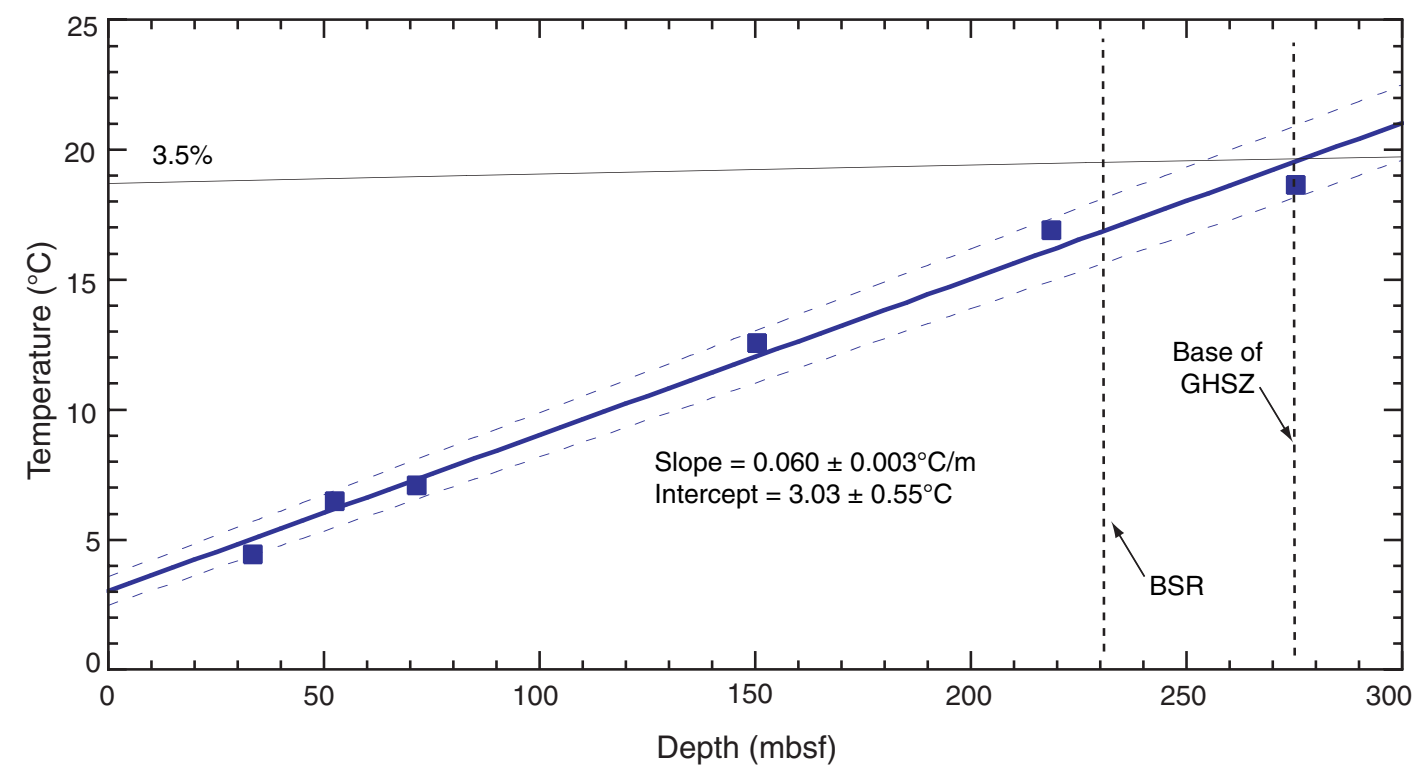


Figure F45. Paleomagnetic data after $20 \mathrm{mT}$ alternating-field demagnetization from Holes U1325B and U1325C.

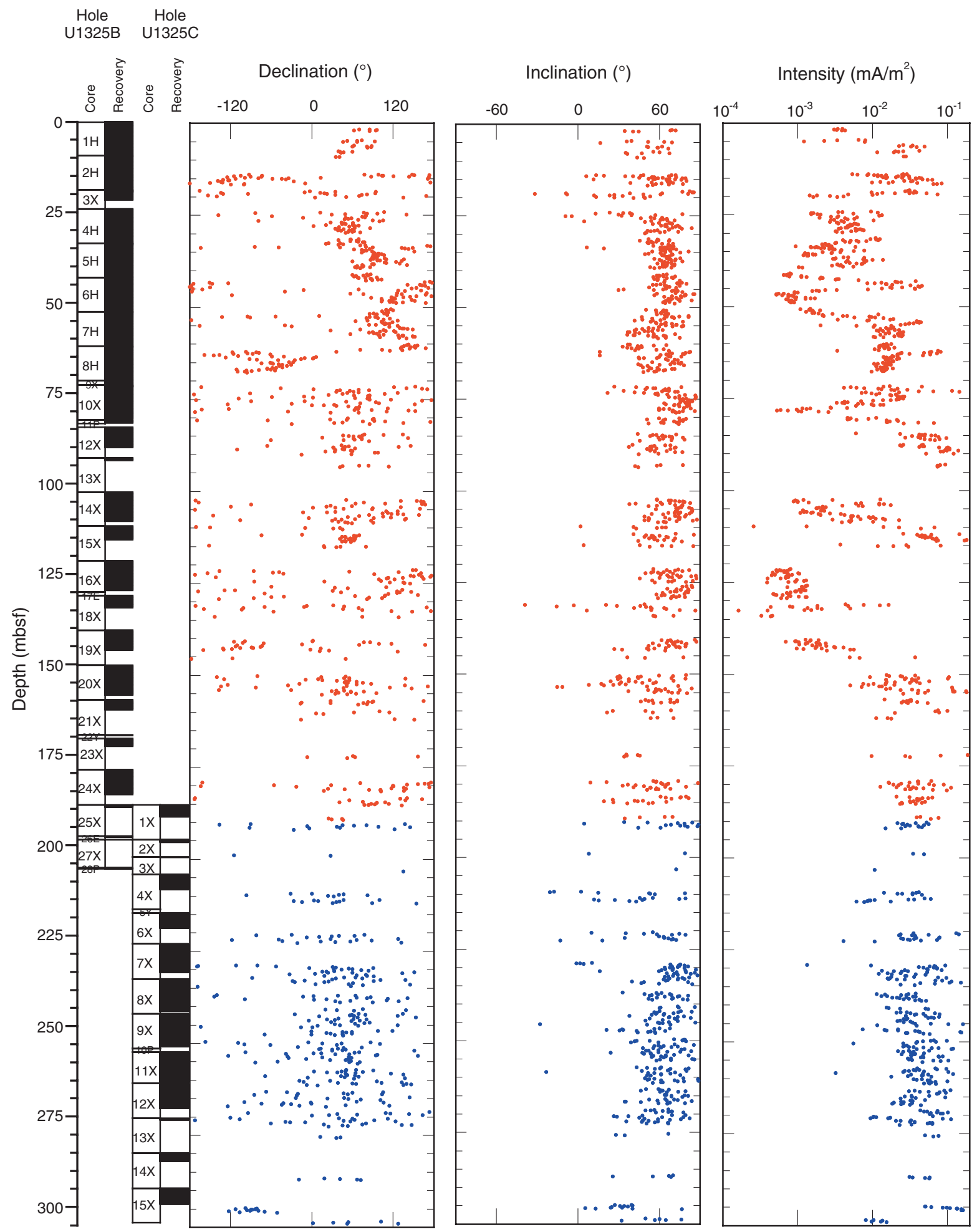


Figure F46. Temperature and pressure vs. elapsed time for each pressure core deployment as recorded by the corer's internal data logger. Cores 311-U1328B-11P, 17E, and 28P were not chilled. There are no data for the deployment of Core 311-U1325B-22Y, and the data record is incomplete for the deployment of Core 311-U1325B-17E. Note the expanded time axis for Core 311-U1325B-28P, which was recovered by pipe trip. Orange shading $=$ deployment and recovery, yellow shading $=$ operation at coring depth, blue shading $=$ autoclave immersion in the ice shuck . (Continued on next page).

Core 311-U1325B-11P
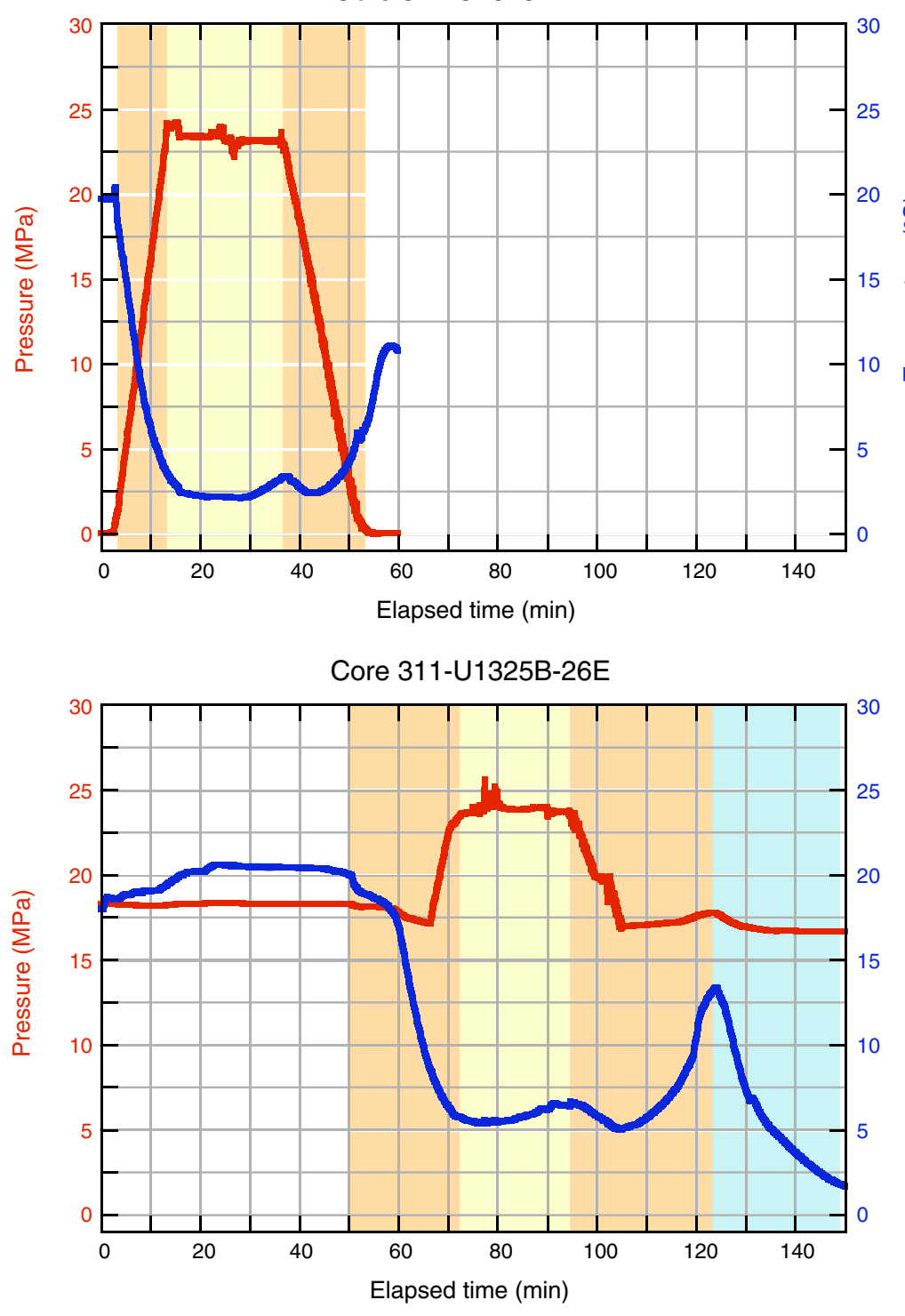

Core 311-U1325B-17E

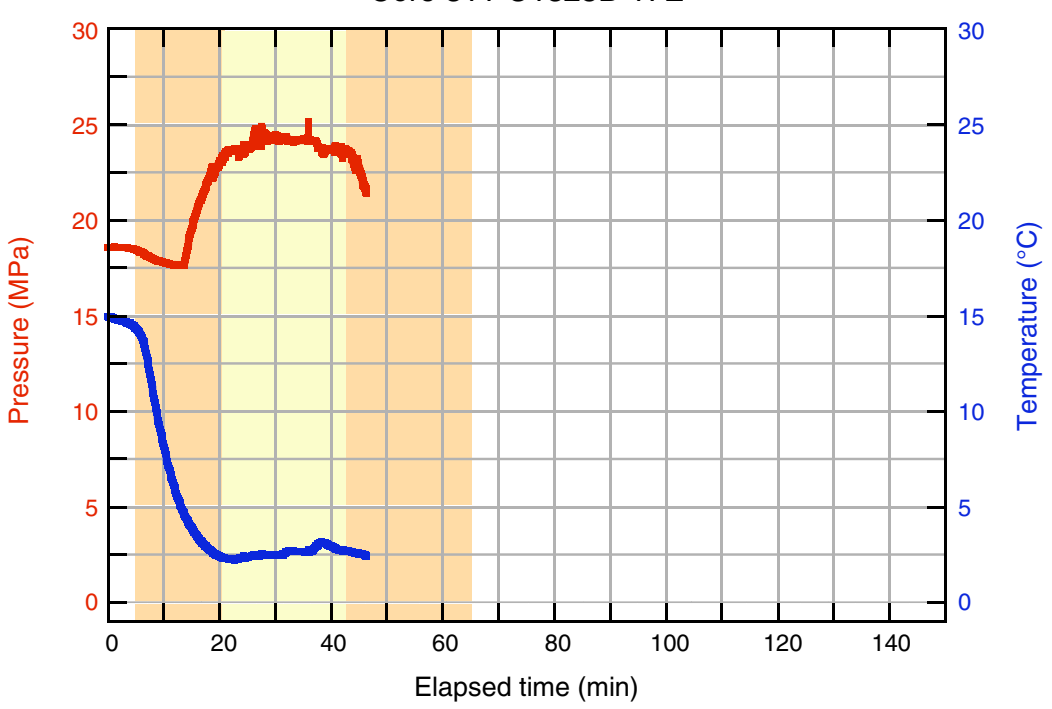

Core 311-U1325B-28P

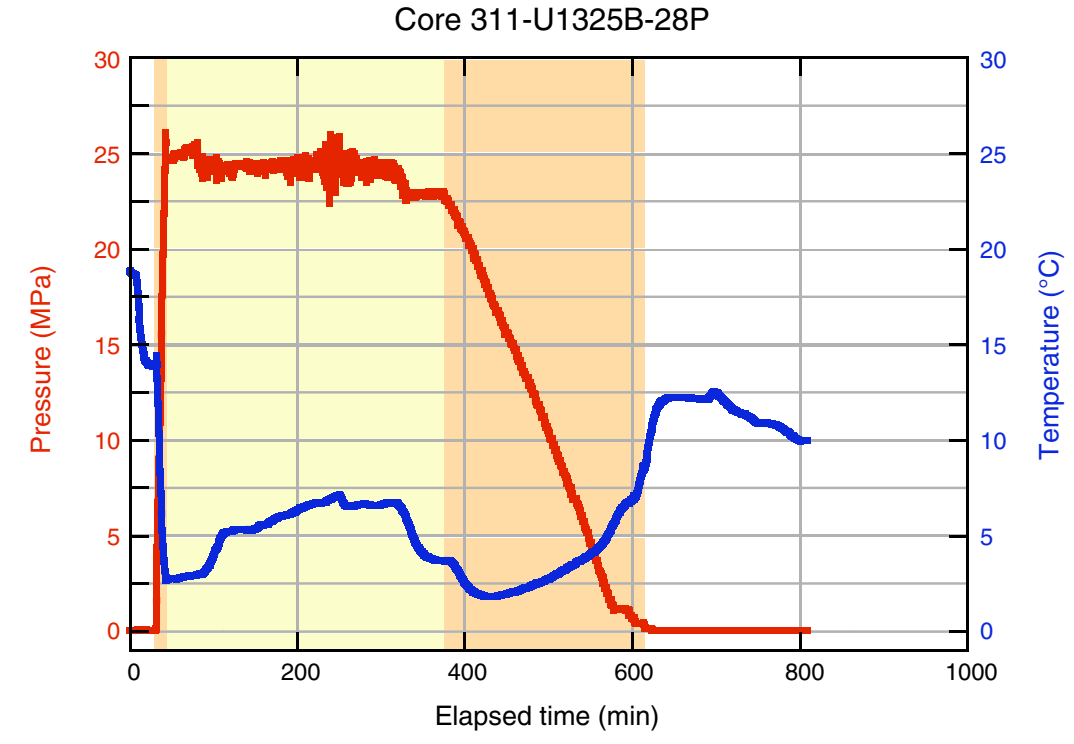


Figure F46 (continued).
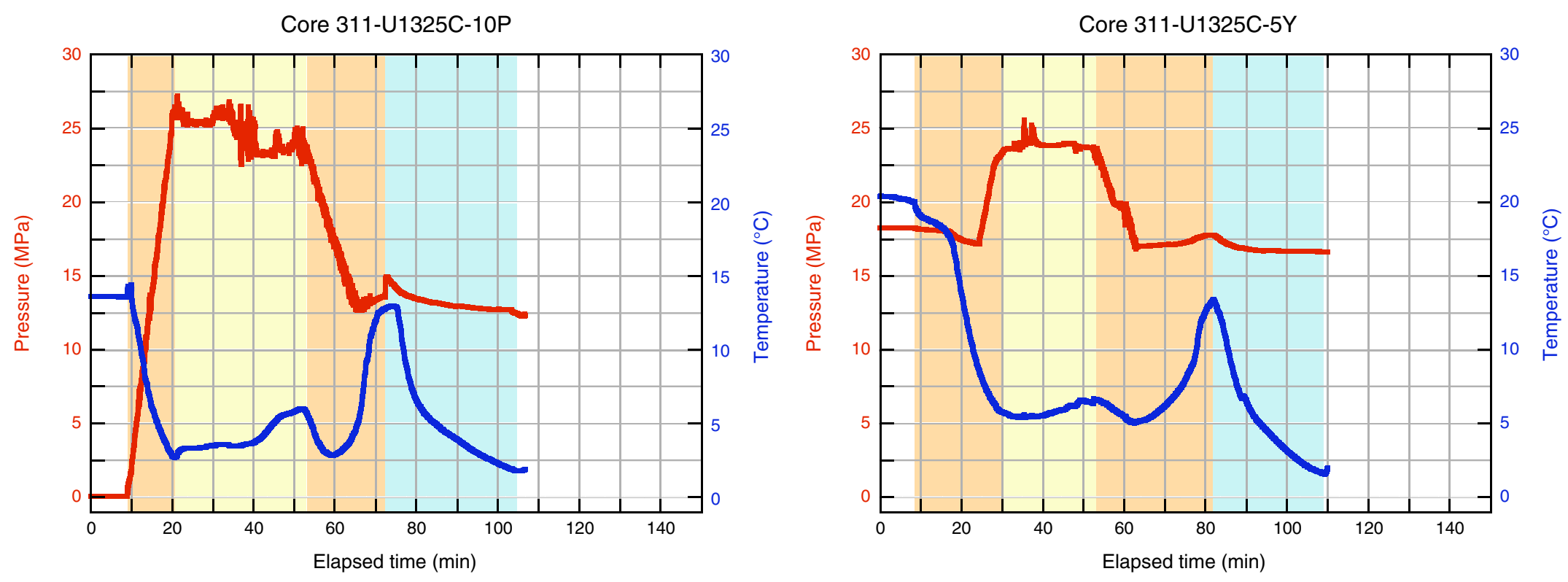
Figure F47. Temperature vs. pressure for all pressure core deployments, showing core histories relative to gas hydrate stability at 30 and $40 \mathrm{ppt}$ salinity $(\mathrm{Xu}, 2002,2004)$. Solid circles = final temperature and pressure of autoclave prior to data logger removal, squares $=$ pressure and temperature conditions in the cold laboratory van. There are no data for the deployment of Core 311-U1325B-22Y.

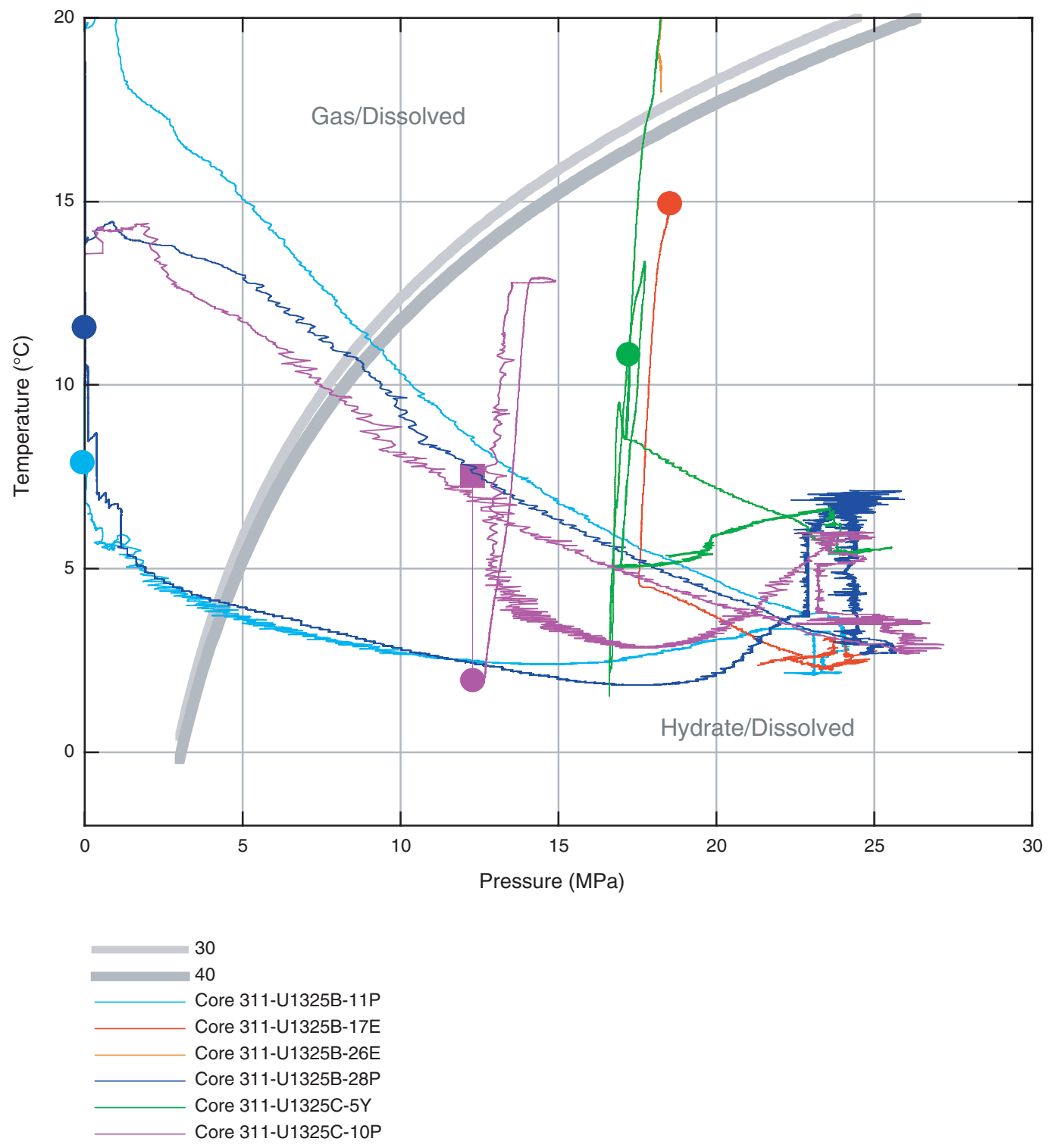


Figure F48. Methane phase diagram, with total methane concentration measured from the single degassed PCS core at Site U1325. The seafloor temperature and thermal gradient were taken from "In situ temperature profile," the salinity profile was taken from Table $\mathbf{T} 4$, and methane saturation was calculated according to $\mathrm{Xu}$ (2002, 2004). BSR = bottom-simulating reflector.

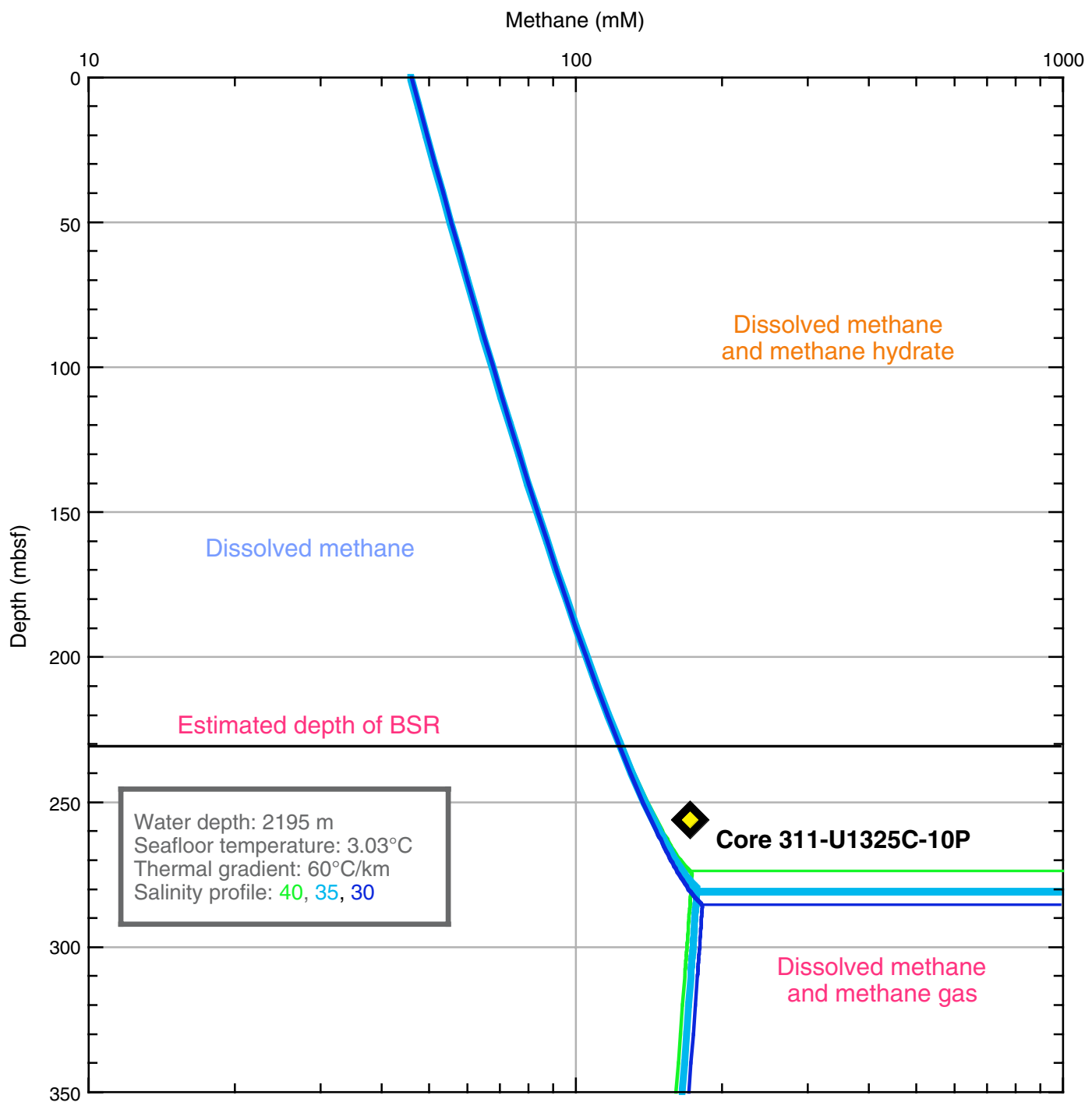


Figure F49. Pressure vs. released gas volume for Core 311-U1325C-10P. Arrows = placement of gamma ray density scans. Placement of Scan 4 was not recorded.

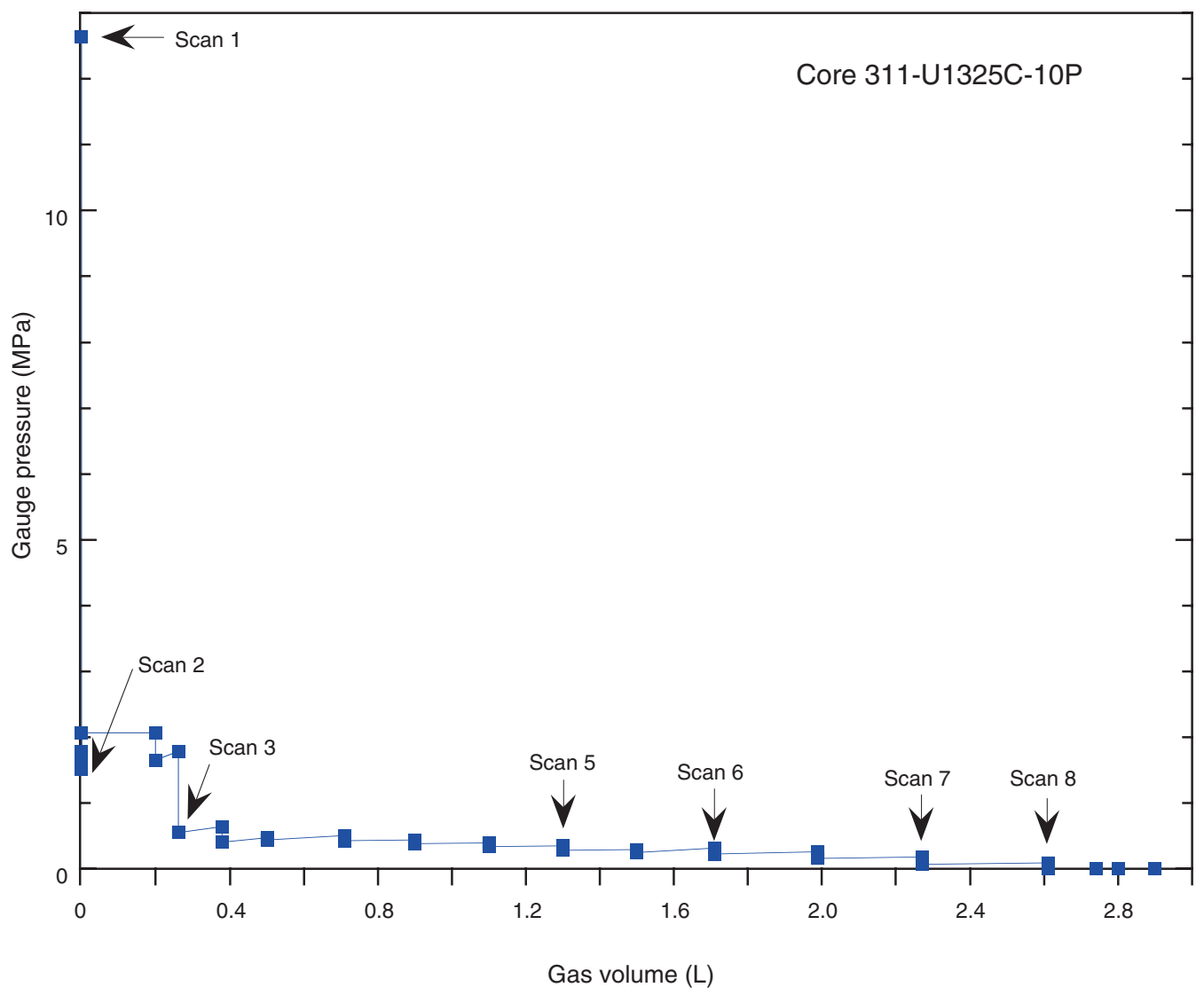


Figure F50. Summary of depth-dependent data collected from Core 311-U1325C-10P, including gamma ray density scans collected during degassing, X-ray images collected before degassing, line scan images collected after degassing, and chlorinity data collected in selected zones after core extrusion. Gamma ray density scans are shown as differential density plots (i.e., profiles from which the initial profile has been subtracted).
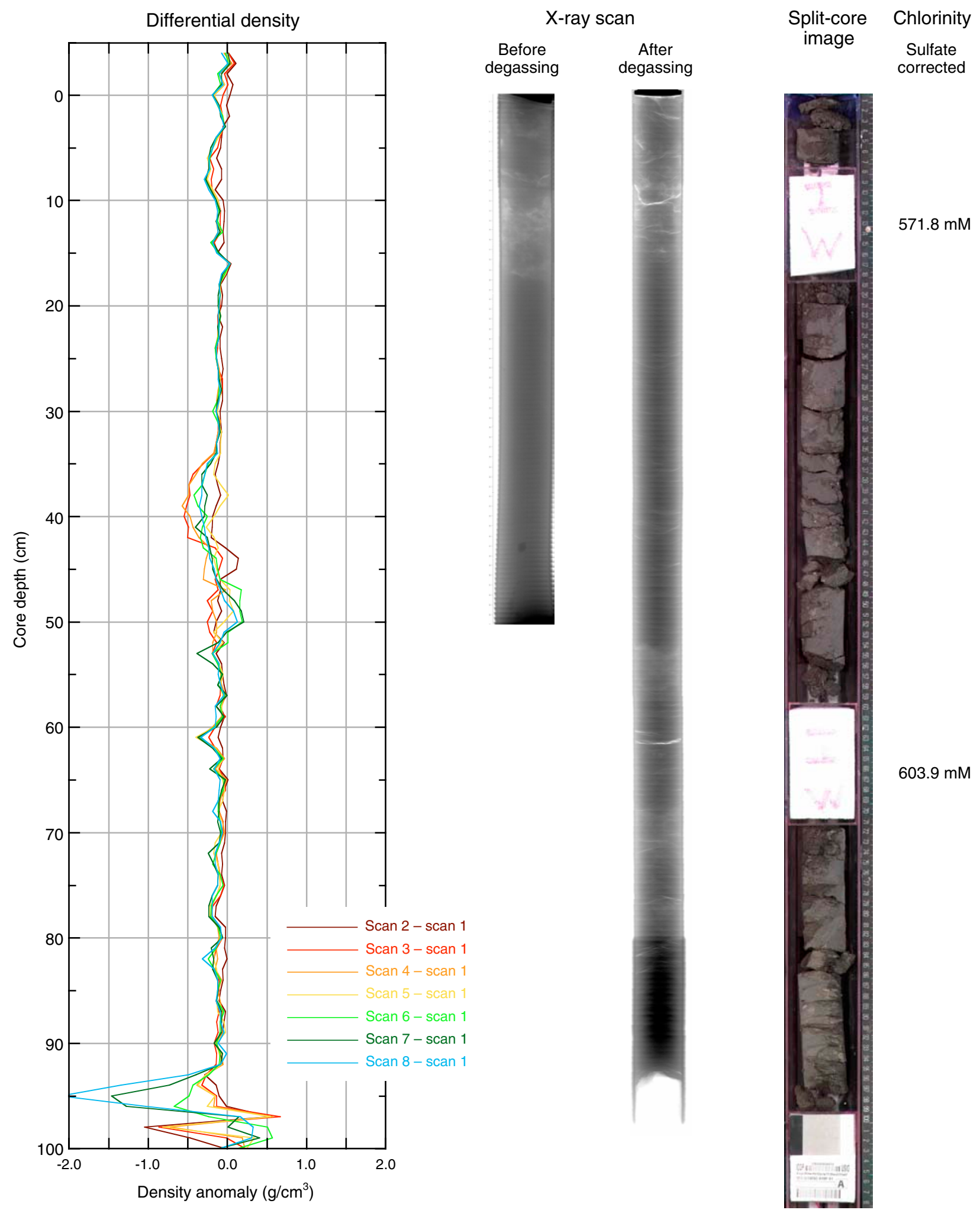
Figure F51. Monitoring and quality control LWD/MWD logs from Hole U1325A.

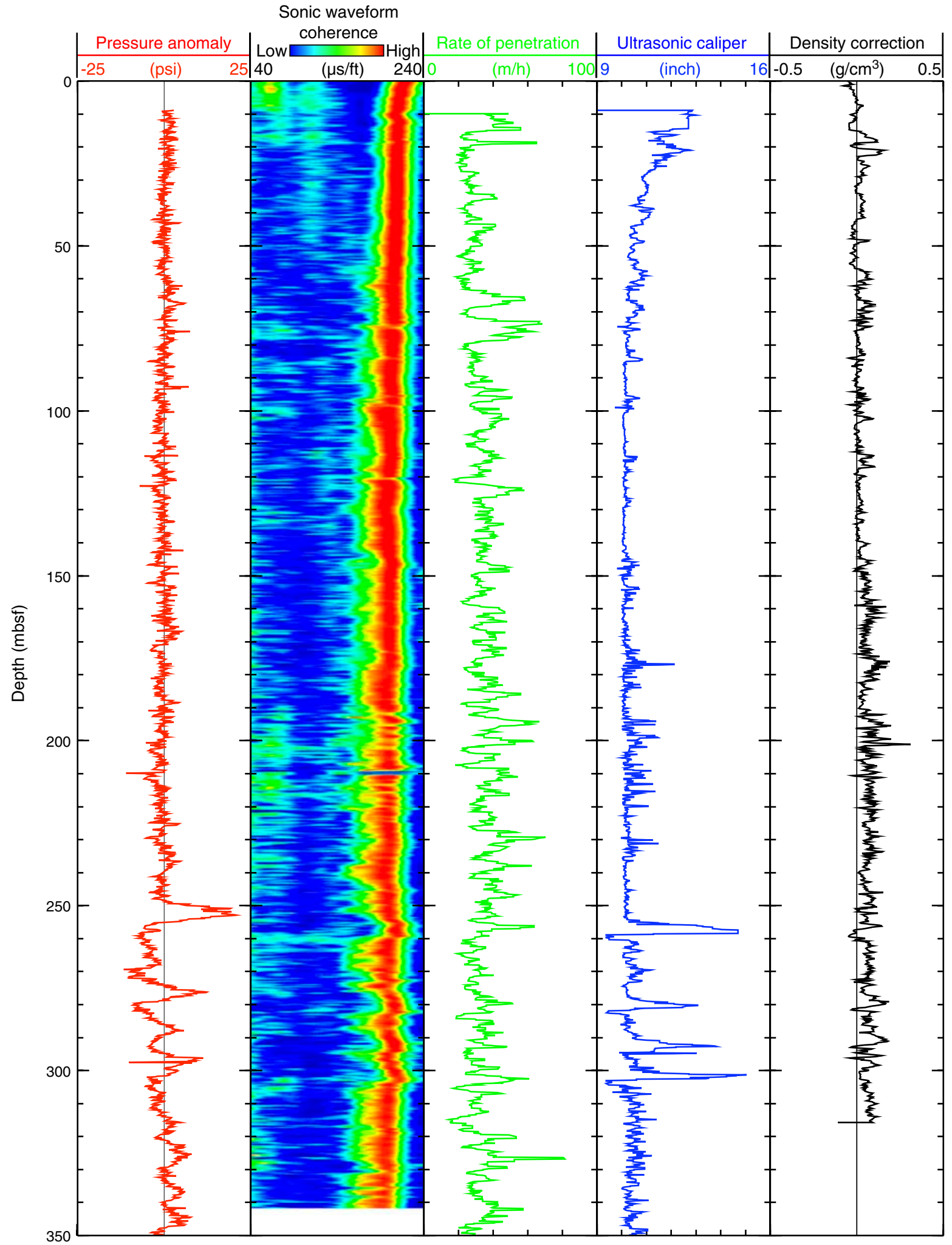


Figure F52. Summary of LWD data from Hole U1325A. avg = average, P16B = phase-shift resistivity measured by the EcoScope tool at a source-receiver spacing of 16 inch $(41 \mathrm{~cm}), \mathrm{A} 40 \mathrm{~B}=$ attenuation resistivity measured by the EcoScope tool at a source-receiver spacing of 40 inch $(102 \mathrm{~cm}), \mathrm{RAB}=$ resistivity-at-the-bit image obtained by the GeoVISION tool.

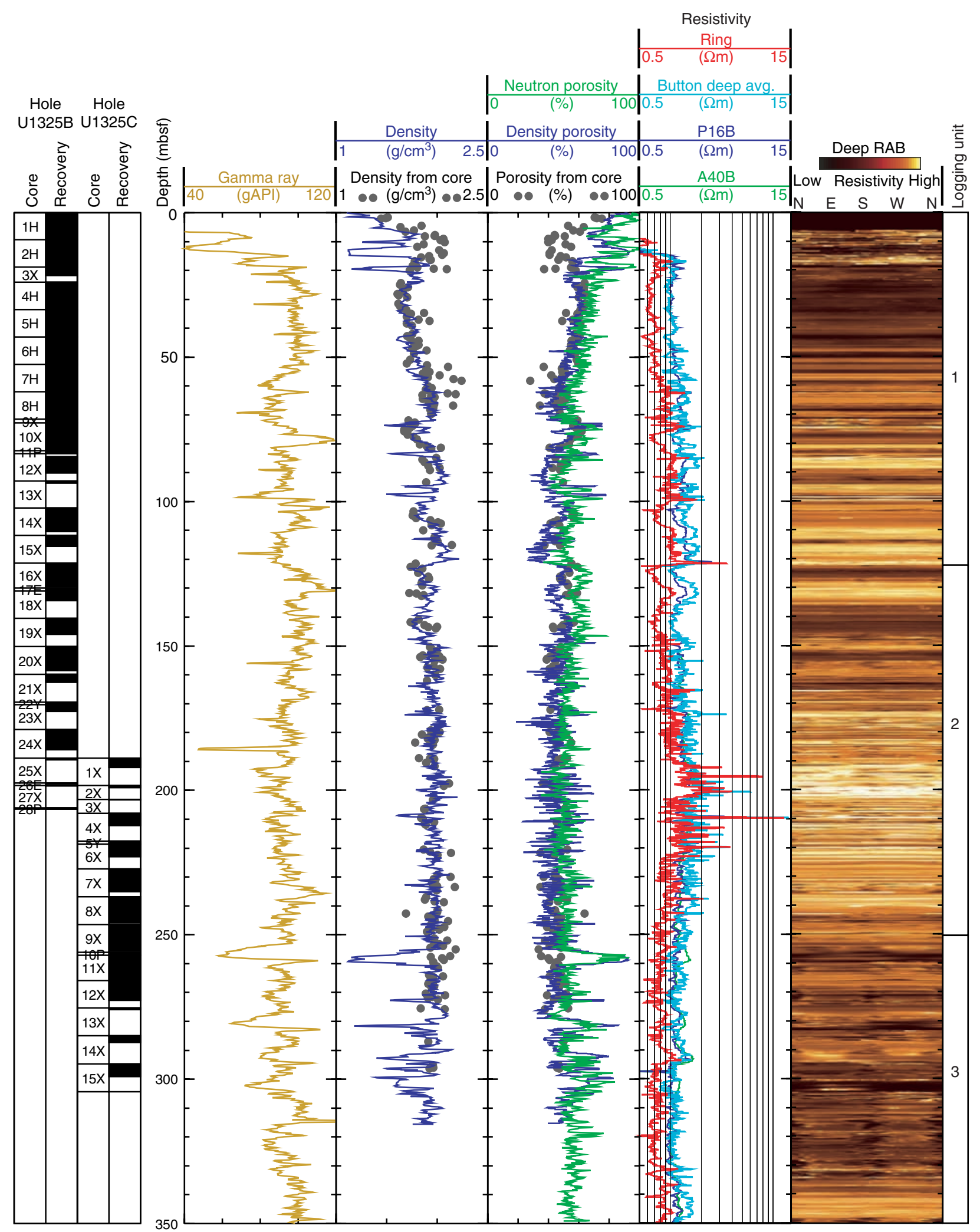


Figure F53. Summary of wireline logging data from Hole U1325C. SFLU $=$ spherically focused resistivity, $V_{\mathrm{P}}=$ $P$-wave velocity, $V_{\mathrm{S}}=S$-wave velocity.

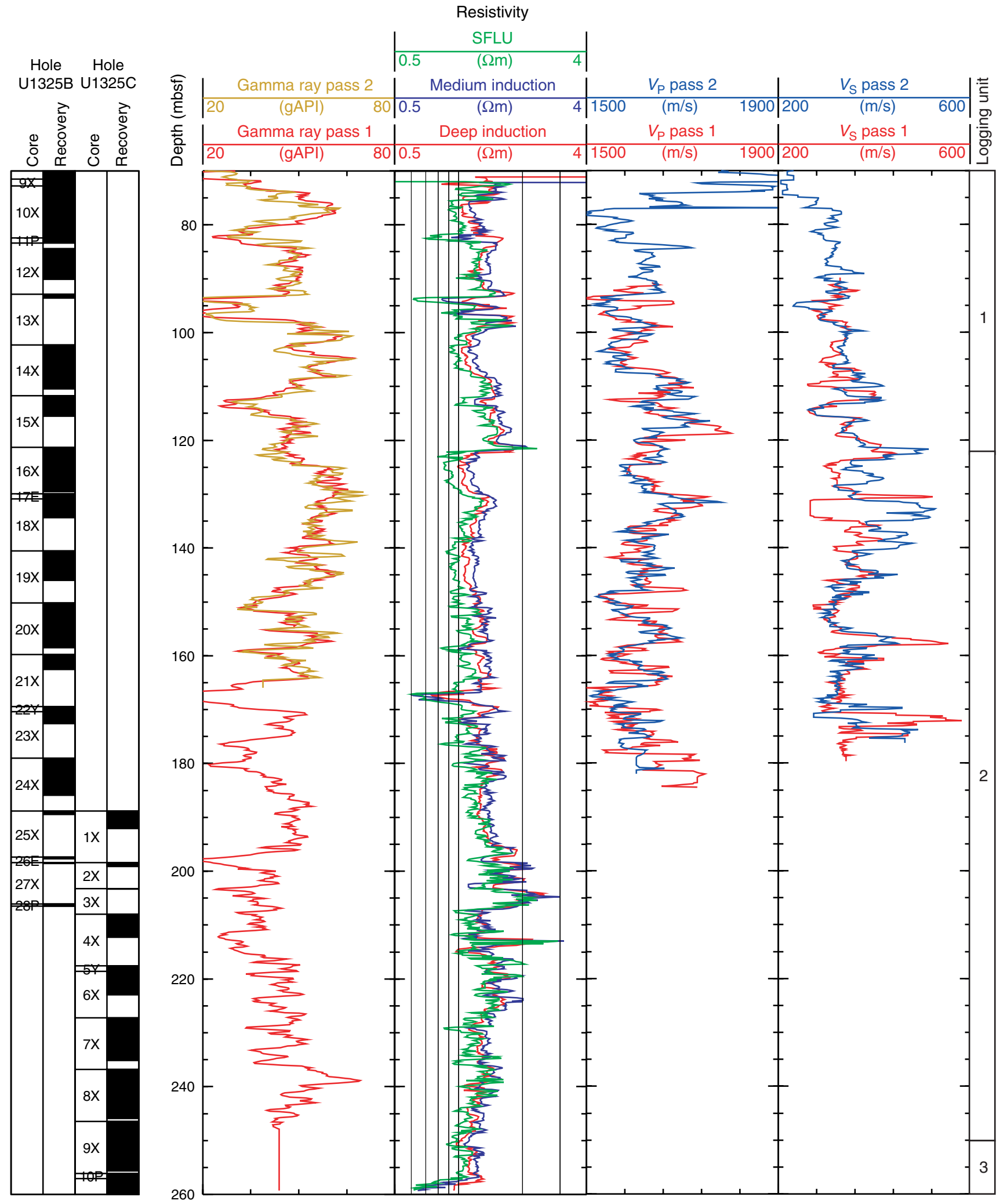


Figure F54. Sonic waveform data, $P$-wave velocity $\left(V_{\mathrm{p}}\right)$, and $S$-wave $\left(V_{\mathrm{S}}\right)$ velocity obtained with the wireline Dipole Sonic Imager tool in Hole U1325C. SFLU = spherically focused resistivity, Mono $=$ monopole, UD = upper dipole, $\mathrm{LD}=$ lower dipole.

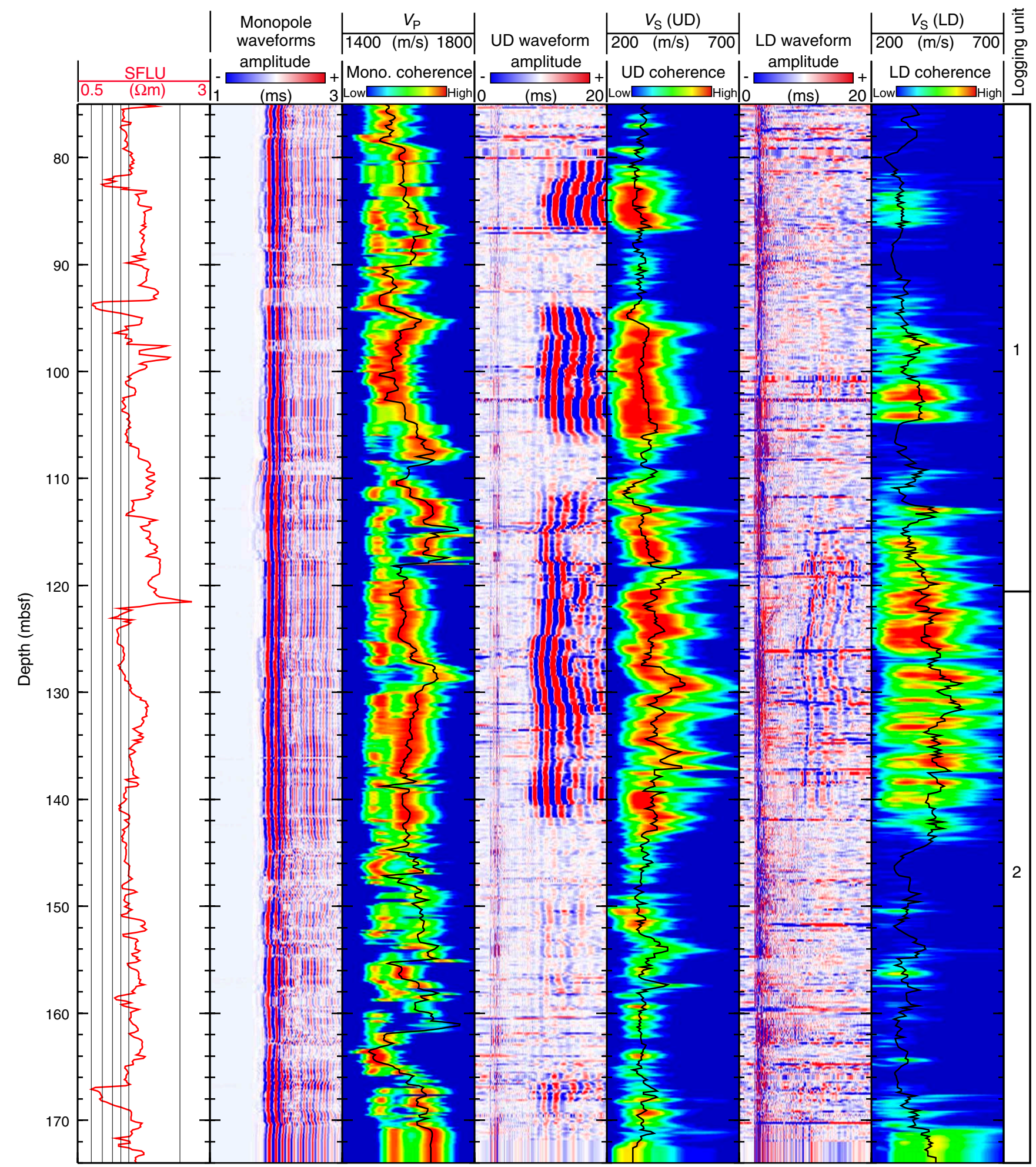


Figure F55. Comparison of logging-while-drilling (LWD; Hole U1325A) and wireline (WL) logging (Hole U1325C) data. SFLU = spherically focused resistivity, P16B = phase-shift resistivity measured by the EcoScope tool at a source-receiver spacing of 16 inch $(41 \mathrm{~cm})$, avg = average.

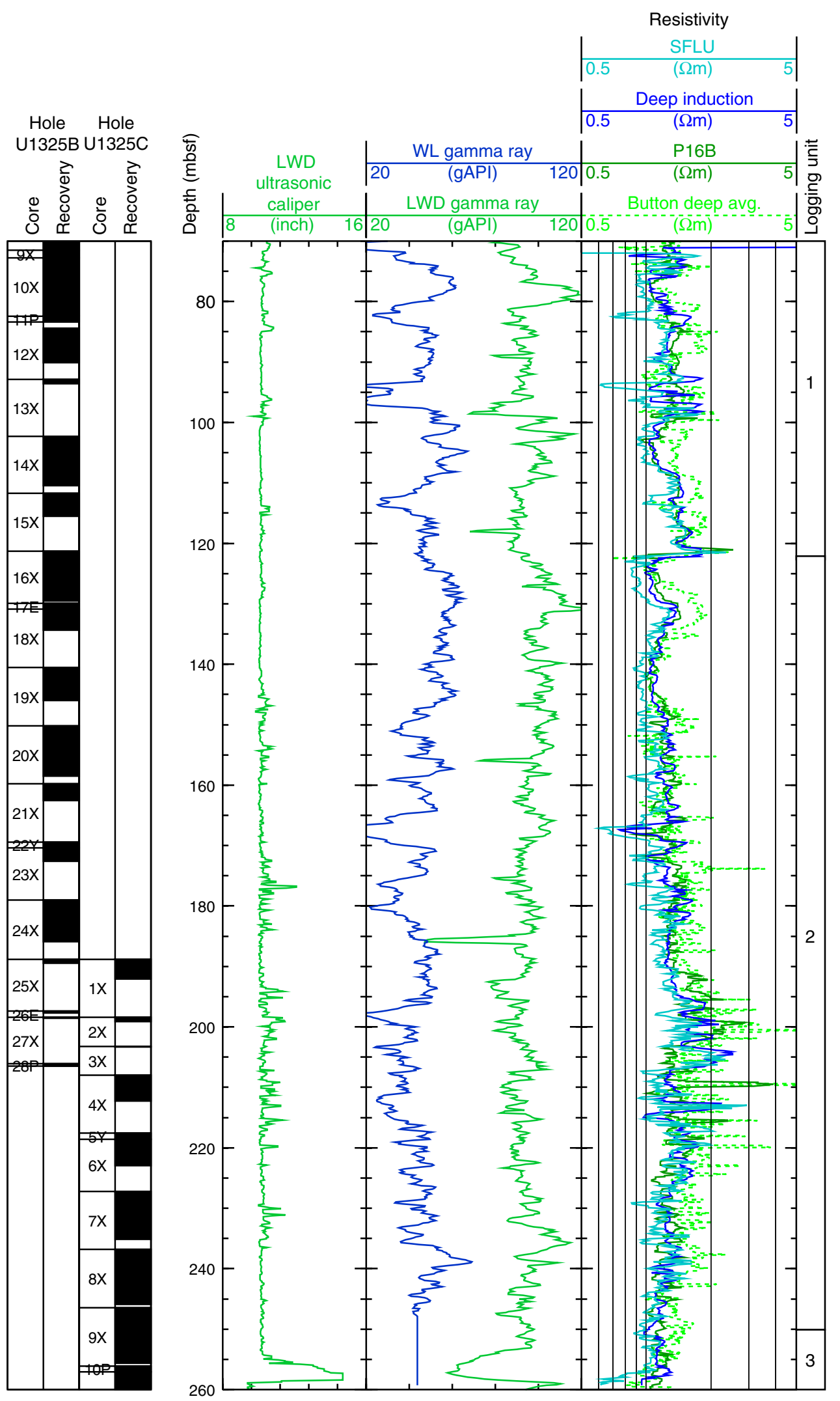


Figure F56. LWD image data from Hole U1325A. RAB = resistivity-at-the-bit image obtained by the GeoVISION tool.
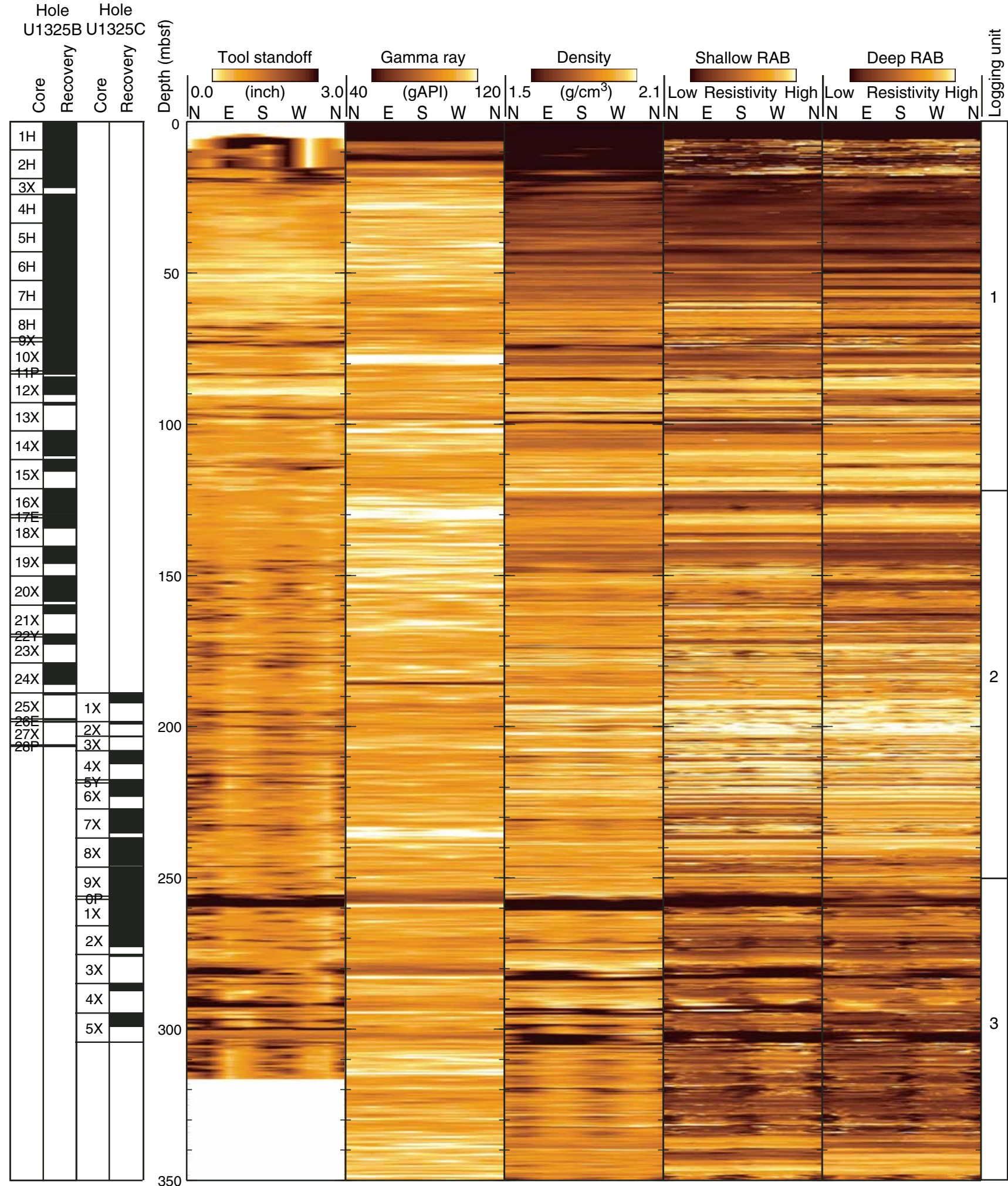
Figure F57. Comparison of LWD porosity logs with core-derived porosity data.
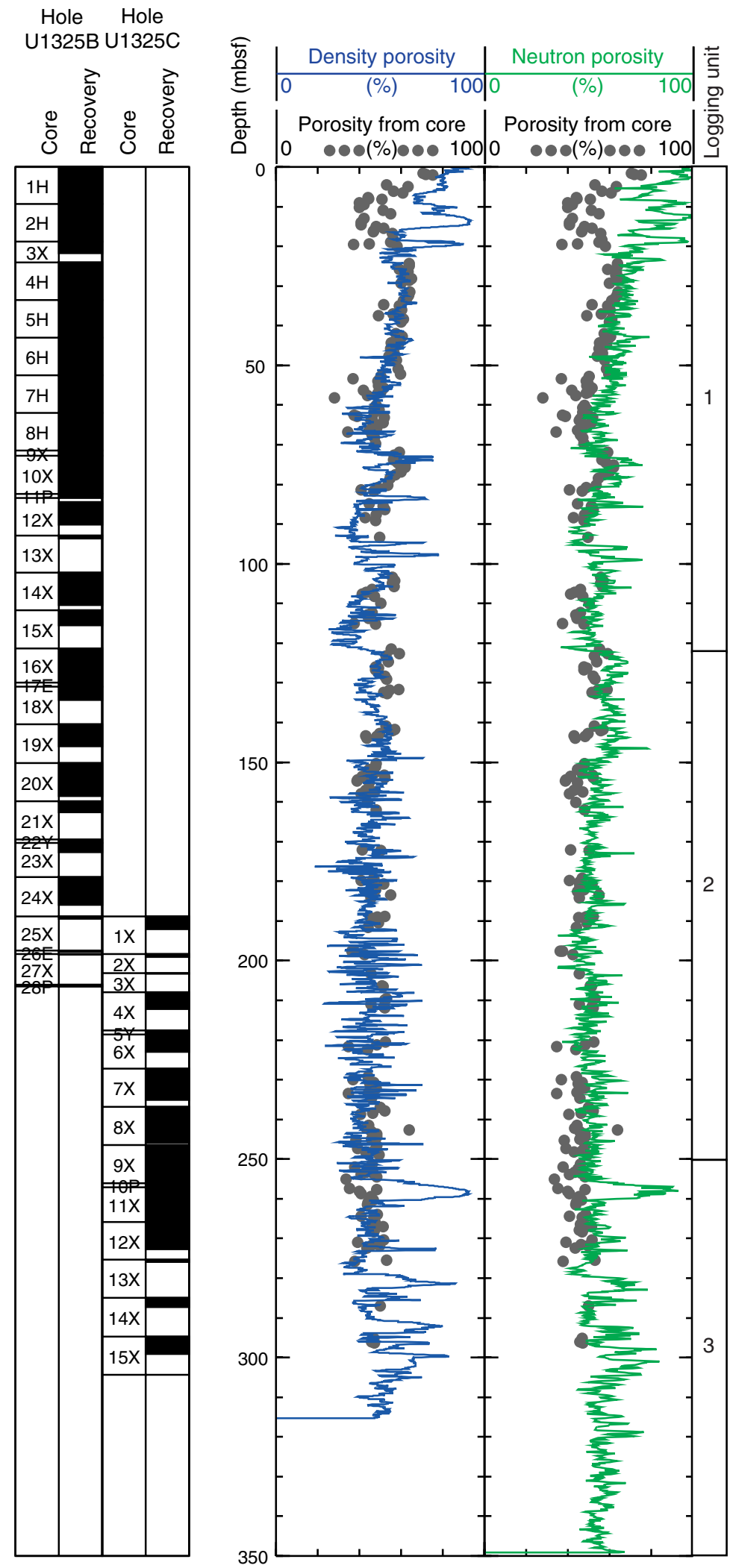
Figure F58. Water saturation from Archie's equation and LWD porosity and resistivity logs. Shaded intervals correspond to hole enlargements, where the measured density is erroneously low and the calculated water saturation is unreliable. $R_{\mathrm{w}}=$ formation water resistivity, $m=$ cementation coefficient, $R_{0}=$ computed formation resistivity for $100 \%$ water saturation, $R_{\mathrm{t}}=$ measured resistivity, $S_{\mathrm{w}}=$ water saturation, RAB = resistivity-at-thebit image obtained by the GeoVISION tool.

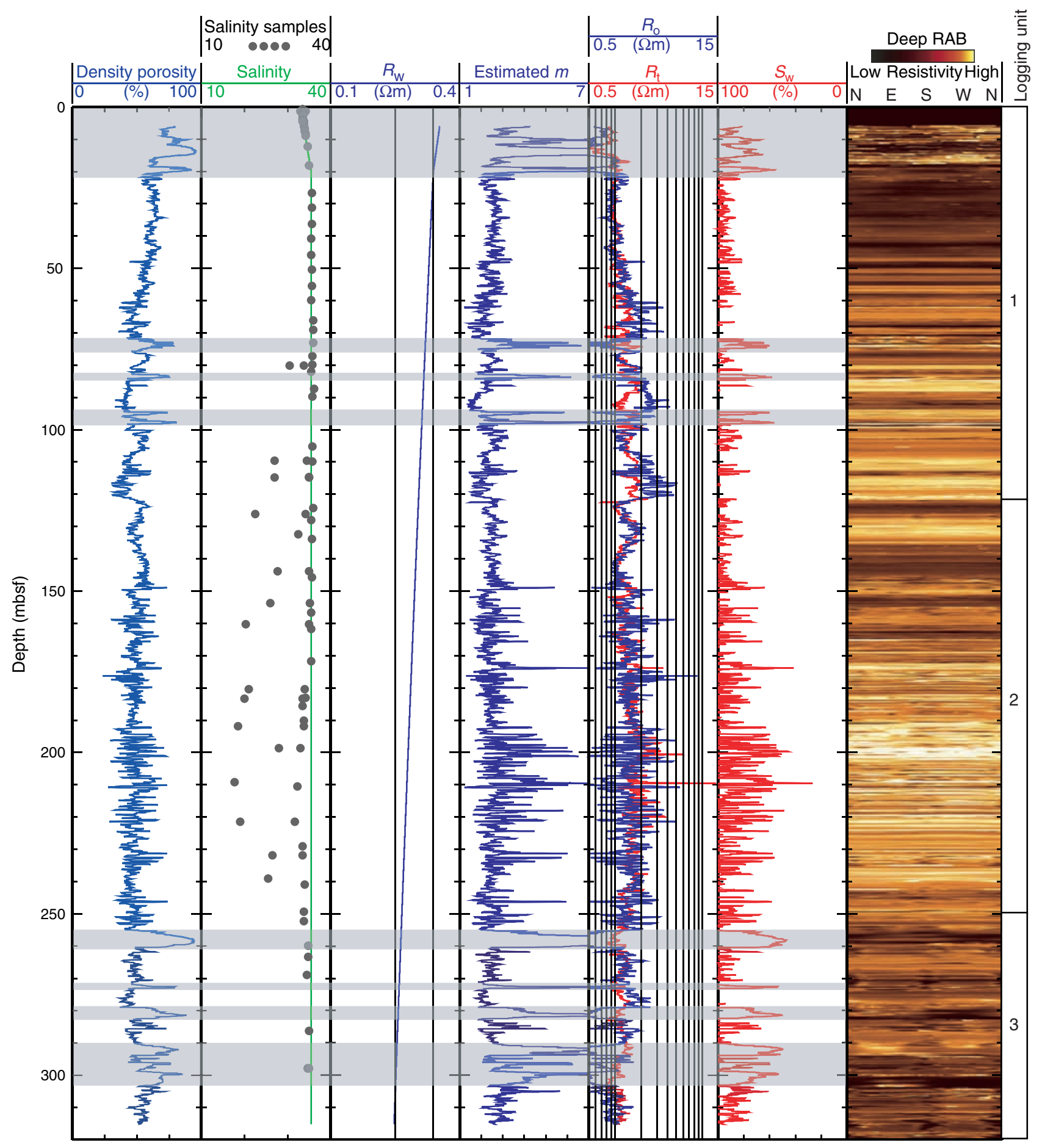


Figure F59. Comparison between LWD resistivity (Hole U1325A), wireline resistivity (Hole U1325C), and infrared (IR) images (Holes U1325B and U1325C). Note that the IR images for 0-189 mbsf are from Hole U1325B, and the IR images for 189-300 mbsf are from Hole U1325C. RAB = resistivity-at-the-bit, avg = average, $\mathrm{P} 16 \mathrm{~B}=$ EcoScope phase-shift resistivity, A40B = EcoScope attenuation resistivity, SFLU = spherically focused resistivity, Med = medium.

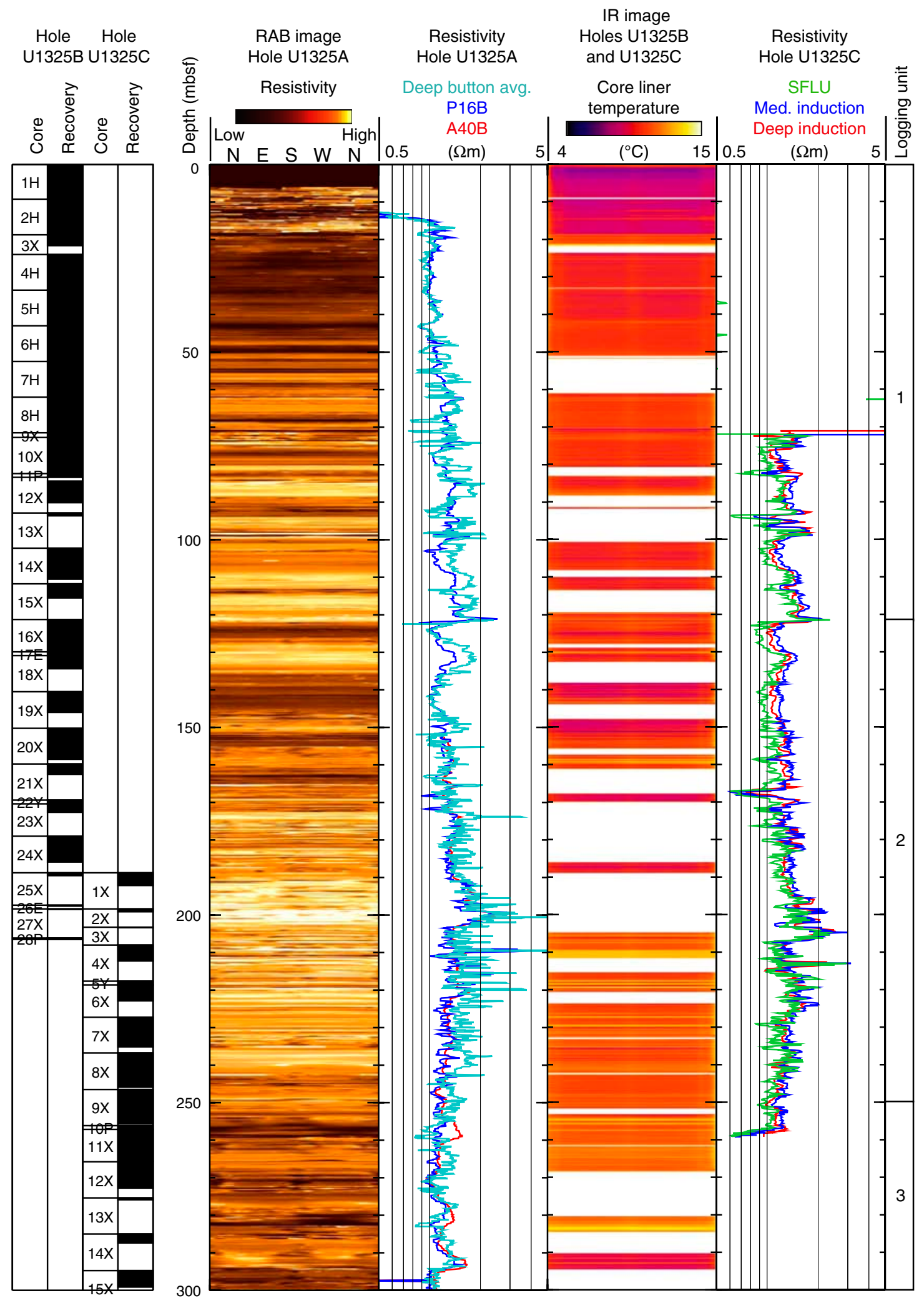


Figure F60. Borehole temperatures recorded with the Temperature/Acceleration/Pressure tool in Hole U1325C.

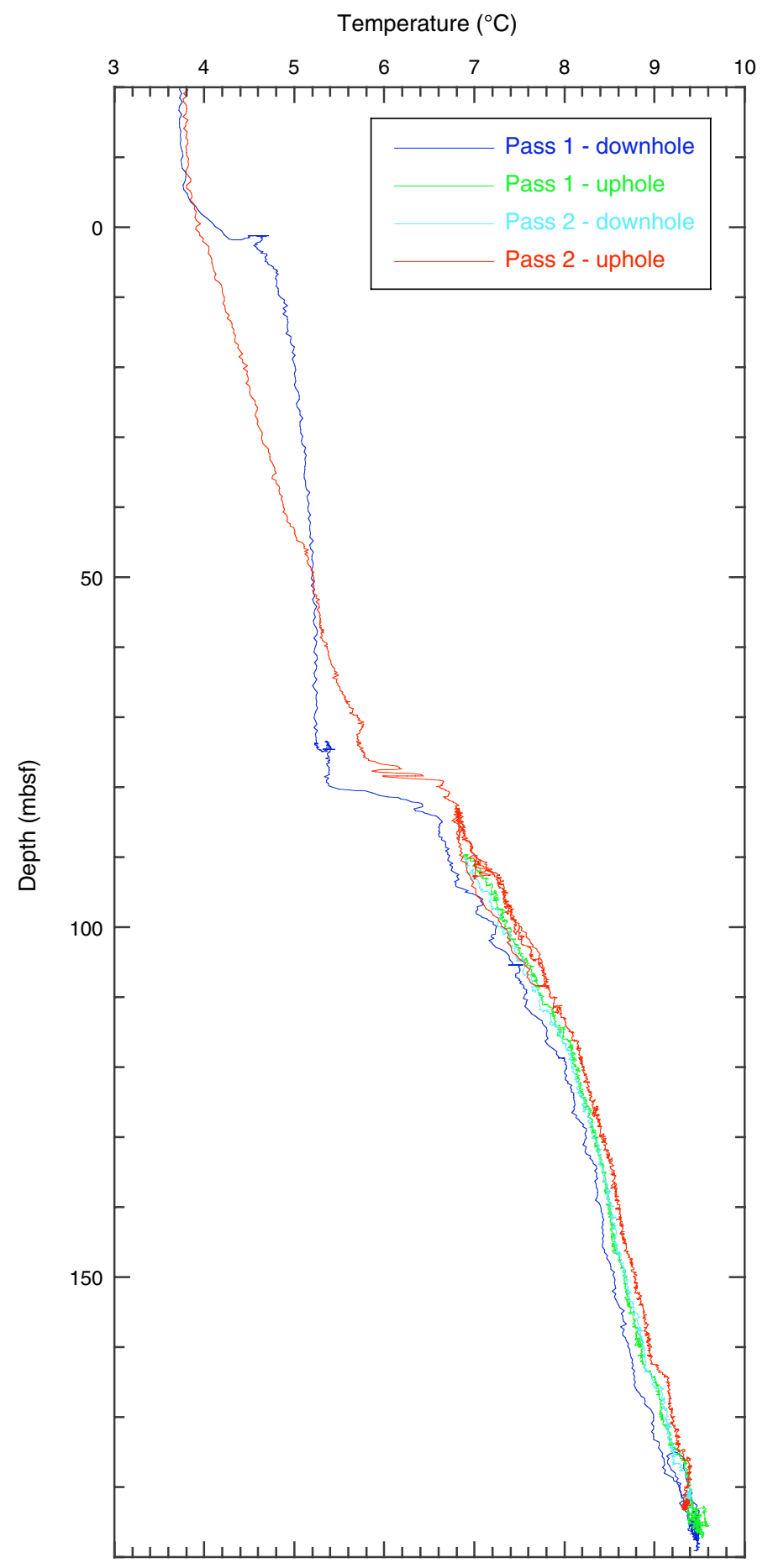


Table T1. Site U1325 coring summary. (See table note. Continued on next page.)

\begin{tabular}{|c|c|c|c|c|c|c|c|}
\hline $\begin{array}{c}\text { Hole U13 } \\
\text { Latitud } \\
\text { Longitu } \\
\text { Seafloo } \\
\text { Distanc } \\
\text { Water } ~ \\
\text { Total pe } \\
\text { Total d }\end{array}$ & $\begin{array}{l}25 \mathrm{~A} \\
: 48^{\circ} 38 \\
\text { de: } 126 \\
\text { r(drill } p \\
\text { e betwe } \\
\text { lepth (d } \\
\text { enetratic } \\
\text { illed int }\end{array}$ & $\begin{array}{l}6911^{\prime} \mathrm{N} \\
58.991 \\
\text { pe mea } \\
\text { en rig flc } \\
\text { ill pipe } \\
\text { n (mbsf } \\
\text { rval }(\mathrm{m})\end{array}$ & $\begin{array}{l}v \\
\text { irement } \\
\text { or and se } \\
\text { leasuren } \\
350.0 \\
350.0 ;\end{array}$ & $\begin{array}{l}\text { rom rig } \mathrm{f} \\
\text { level }(\mathrm{m} \\
\text { ent from } \\
\text { ND/MWD }\end{array}$ & $\begin{array}{l}\text { oor, mbrf): } \\
\text { ): } 10.9 \\
\text { sea level, } m\end{array}$ & $\begin{array}{l}2212.0 \\
2201.1\end{array}$ & \\
\hline $\begin{array}{c}\text { Hole U13 } \\
\text { Latitud } \\
\text { Longitu } \\
\text { Seafloo } \\
\text { Distanc } \\
\text { Water c } \\
\text { Total pe } \\
\text { Total d }\end{array}$ & $\begin{array}{l}\text { 25B } \\
\text { : } 48^{\circ} 38 \\
\text { de: } 126 \\
\text { r(drill } p \\
\text { e betwe } \\
\text { lepth (d } \\
\text { netratic } \\
\text { illed int }\end{array}$ & $\begin{array}{l}694^{\prime} \mathrm{N} \\
58.999 \\
\text { pe mea } \\
\text { en rig flc } \\
\text { ill pipe } \\
\text { n (mbsf } \\
\text { rval (m) }\end{array}$ & $\begin{array}{l}\text { V } \\
\text { rement } \\
\text { r and se } \\
\text { heasurem } \\
206.5 \\
1\end{array}$ & $\begin{array}{l}\text { rom rig } f \\
\text { level ( } \\
\text { ent from }\end{array}$ & $\begin{array}{l}\text { oor, mbrf): } \\
\text { ): } 11.4 \\
\text { sea level, m }\end{array}$ & $\begin{array}{l}2206.2 \\
: 2194.8\end{array}$ & \\
\hline $\begin{array}{c}\text { Hole U13 } \\
\text { Latitud } \\
\text { Longitu } \\
\text { Seafloo } \\
\text { Distanc } \\
\text { Water } ~ \\
\text { Total pe } \\
\text { Total dr }\end{array}$ & $\begin{array}{l}25 \mathrm{C} \\
: 48^{\circ} 38 \\
\text { de: } 126 \\
\text { r(drill } p \\
\text { e betwe } \\
\text { lepth (d } \\
\text { netratic } \\
\text { illed int }\end{array}$ & $\begin{array}{l}701^{\prime} \mathrm{N} \\
59.007 \\
\text { pe meas } \\
\text { en rig flc } \\
\text { ill pipe } \\
\text { n (mbsf } \\
\text { rval (m) }\end{array}$ & $\begin{array}{l}V \\
\text { urement } \\
\text { or and se } \\
\text { leasurem } \\
304.3 \\
188.8\end{array}$ & $\begin{array}{l}\text { rom rig } f \\
\text { level ( } m \\
\text { ent from }\end{array}$ & $\begin{array}{l}\text { oor, mbrf): } \\
): 11.4 \\
\text { sea level, } m\end{array}$ & $\begin{array}{l}2206.2 \\
: 2194.8\end{array}$ & \\
\hline $\begin{array}{c}\text { Hole U13 } \\
\text { Latitud } \\
\text { Longitu } \\
\text { Seafloo } \\
\text { Distanc } \\
\text { Water c } \\
\text { Total pe }\end{array}$ & $\begin{array}{l}\text { 25D } \\
\text { de: } 126 \\
\text { d (drill } p \\
\text { e betwe } \\
\text { lepth (d } \\
\text { netratic }\end{array}$ & $\begin{array}{l}701^{\prime} \mathrm{N} \\
59.007 \\
\text { pe meas } \\
\text { en rig flc } \\
\text { ill pipe } \\
\text { n (mbsf }\end{array}$ & $\begin{array}{l}\text { V } \\
\text { rement } \\
\text { or and se } \\
\text { leasuren } \\
4.7\end{array}$ & $\begin{array}{l}\text { rom rig } \mathrm{f} \\
\text { level }(\mathrm{m} \\
\text { ent from }\end{array}$ & $\begin{array}{l}\text { oor, mbrf): } \\
\text { ): } 11.6 \\
\text { sea level, } m\end{array}$ & $\begin{array}{l}204.8 \\
: 2193.2\end{array}$ & \\
\hline $\begin{array}{l}\text { Core, } \\
\text { section }\end{array}$ & $\begin{array}{c}\text { Date } \\
\text { (Oct } \\
2005)\end{array}$ & $\begin{array}{l}\text { Local } \\
\text { time } \\
\text { (h) }\end{array}$ & $\begin{array}{c}\text { Top } \\
\text { depth } \\
\text { (mbsfo }\end{array}$ & Leng & $\frac{\text { th }(m)}{\text { Recovered }}$ & $\begin{array}{l}\text { Recovery } \\
(\%)\end{array}$ & Comments \\
\hline 311-U13 & $25 \mathrm{~A}-{ }_{* \star * *}$ & *Drilled & rom 0.0 & o 350.0 & $n b s f^{\star \star \star \star \star *}$ & & LWD/MWD \\
\hline $311-U 13$ & $25 \mathrm{~B}-$ & & & & & & \\
\hline $1 \mathrm{H}$ & 17 & 1925 & 0.0 & 9.3 & 9.44 & 101.5 & WSTP; fluorescent microspheres \\
\hline $2 \mathrm{H}$ & 17 & 2315 & $\begin{array}{r}9.3 \\
189\end{array}$ & 9.5 & 10.13 & $\begin{array}{r}106.6 \\
550\end{array}$ & Fluorescent microspheres; bent barrel, kinked wireline \\
\hline $3 x$ & 18 & 0400 & 18.8 & 5.2 & 2.86 & 55.0 & Fluorescent microspheres \\
\hline $4 \mathrm{H}$ & 18 & 0525 & 24.0 & $\begin{array}{l}9.5 \\
0.5\end{array}$ & $\begin{array}{r}10.01 \\
0.55\end{array}$ & 105.4 & APCT-3; fluorescent microspheres \\
\hline $6 \mathrm{H}$ & $\begin{array}{l}18 \\
18\end{array}$ & 0625 & $\begin{array}{l}33.5 \\
430\end{array}$ & $\begin{array}{l}9.5 \\
9.5\end{array}$ & $\begin{array}{l}9.55 \\
976\end{array}$ & $\begin{array}{l}100.5 \\
1027\end{array}$ & $\begin{array}{l}\text { Fluorescent microspheres } \\
\text { APCT-3: fluorescent microspheres }\end{array}$ \\
\hline $\begin{array}{l}6 \mathrm{H} \\
7 \mathrm{H}\end{array}$ & $\begin{array}{l}18 \\
18\end{array}$ & $\begin{array}{l}0740 \\
0845\end{array}$ & $\begin{array}{l}43.0 \\
52.5\end{array}$ & $\begin{array}{l}9.5 \\
9.5\end{array}$ & $\begin{array}{l}9.76 \\
9.72\end{array}$ & $\begin{array}{l}102.7 \\
102.3\end{array}$ & $\begin{array}{l}\text { APCT-3; fluorescent microspheres } \\
\text { Fluorescent microspheres }\end{array}$ \\
\hline $8 \mathrm{H}$ & 18 & 1000 & 62.0 & 9.5 & 9.59 & 100.9 & APCT-3; fluorescent microspheres \\
\hline $9 \mathrm{X}$ & 18 & 1110 & 71.5 & 1.3 & 1.82 & 140.0 & Fluorescent microspheres \\
\hline $10 x$ & 18 & 1215 & 72.8 & 9.6 & 9.45 & 98.4 & Fluorescent microspheres \\
\hline $11 \mathrm{P}$ & 18 & 1315 & 82.4 & 1.0 & 0.88 & 88.0 & \\
\hline & & *Drilled & rom 82. & to 84.4 r & nbsf***** & & Overdrill pressure core \\
\hline $12 \mathrm{X}$ & 18 & 1435 & 84.4 & 8.5 & 5.73 & 67.4 & Fluorescent microspheres \\
\hline $13 x$ & 18 & 1550 & 92.9 & 9.4 & 0.73 & 7.8 & Fluorescent microspheres \\
\hline $14 X$ & 18 & 1725 & 102.3 & 9.4 & 8.14 & 86.6 & Fluorescent microspheres \\
\hline $15 \mathrm{X}$ & 18 & 1855 & 111.7 & 9.6 & 3.82 & 39.8 & Fluorescent microspheres \\
\hline $16 \mathrm{X}$ & 18 & 2015 & 121.3 & 8.6 & 8.24 & 95.8 & Fluorescent microspheres \\
\hline $17 \mathrm{E}$ & 18 & 2145 & 129.9 & 1.0 & 0.00 & 0.0 & \\
\hline $18 \mathrm{X}$ & 18 & 2310 & 130.9 & 9.6 & 3.43 & 35.7 & Fluorescent microspheres \\
\hline $19 x$ & 19 & 0055 & 140.5 & 9.7 & 5.48 & 56.5 & Fluorescent microspheres; DVTP at $150.2 \mathrm{mbsf}$ \\
\hline $20 x$ & 19 & 0405 & 150.2 & 9.6 & 8.29 & 86.4 & Fluorescent microspheres \\
\hline $21 x$ & 19 & 0550 & 159.8 & 9.6 & 2.74 & 28.5 & Fluorescent microspheres \\
\hline $22 \mathrm{Y}$ & 19 & 0725 & 169.4 & 1.0 & 0.17 & 17.0 & \\
\hline $23 x$ & 19 & 0910 & 170.4 & 8.6 & 2.23 & 25.9 & Fluorescent microspheres \\
\hline $24 X$ & 19 & 1020 & 179.0 & 9.8 & 6.87 & 70.1 & Fluorescent microspheres \\
\hline $25 X$ & 19 & 1150 & 188.8 & 8.6 & 0.64 & 7.4 & Fluorescent microspheres \\
\hline $26 \mathrm{E}$ & 19 & 1345 & 197.4 & 1.0 & 0.28 & 28.0 & Fluorescent microspheres \\
\hline $27 X$ & 19 & 1515 & 198.4 & 7.7 & 0.15 & 1.9 & Fluorescent microspheres \\
\hline $28 \mathrm{P}$ & 19 & 1925 & 206.1 & 0.4 & 0.46 & 115.0 & Sheared pin on OS; four attempts, tool lodged in BHA \\
\hline
\end{tabular}


Table T1 (continued).

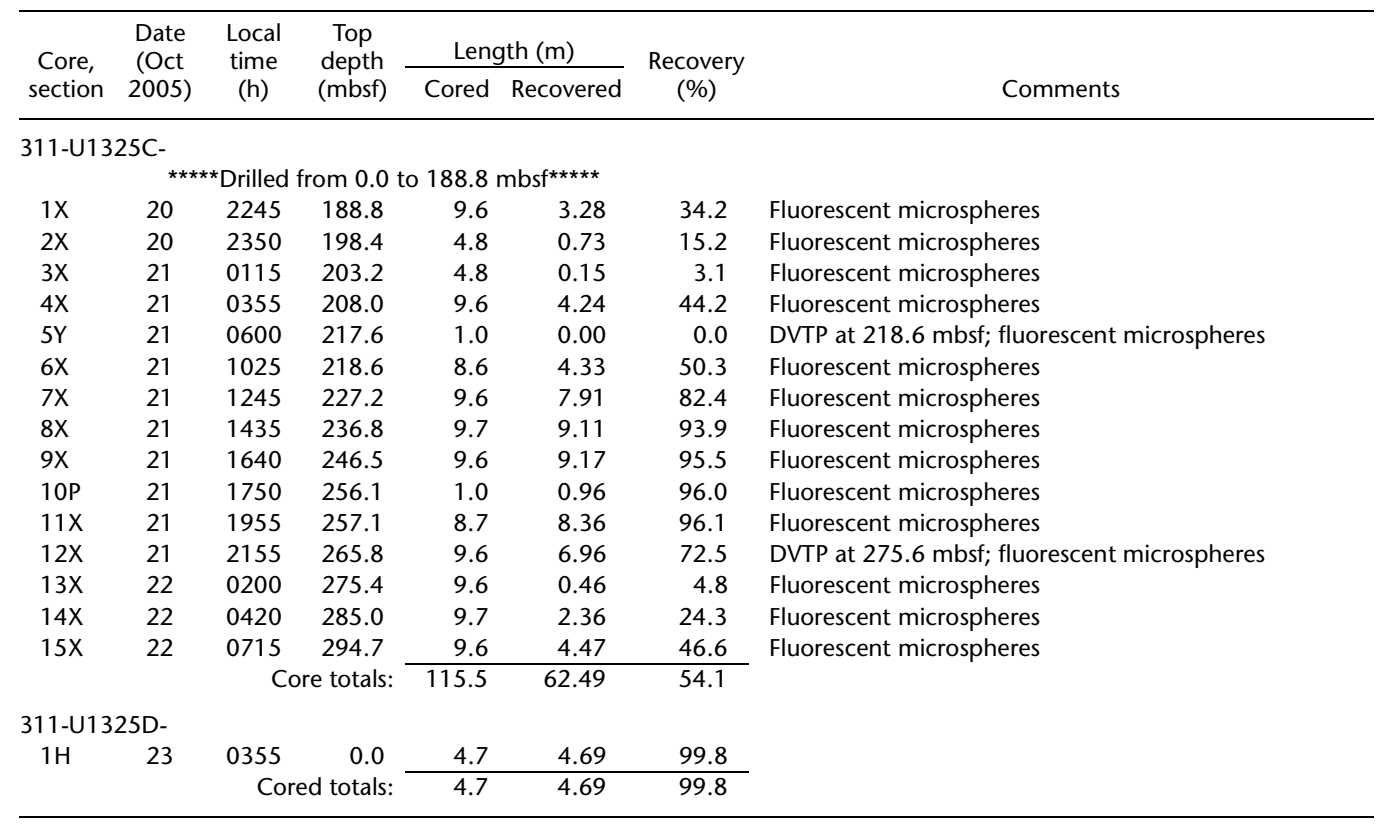

Note: LWD/MWD = logging while drilling/measurement while drilling, WSTP $=$ water-sampling temperature probe, APCT-3 = third-generation advanced piston corer temperature tool, DVTP = Davis-Villinger Temperature Probe, OS = overshot, BHA = bottom-hole assembly. 


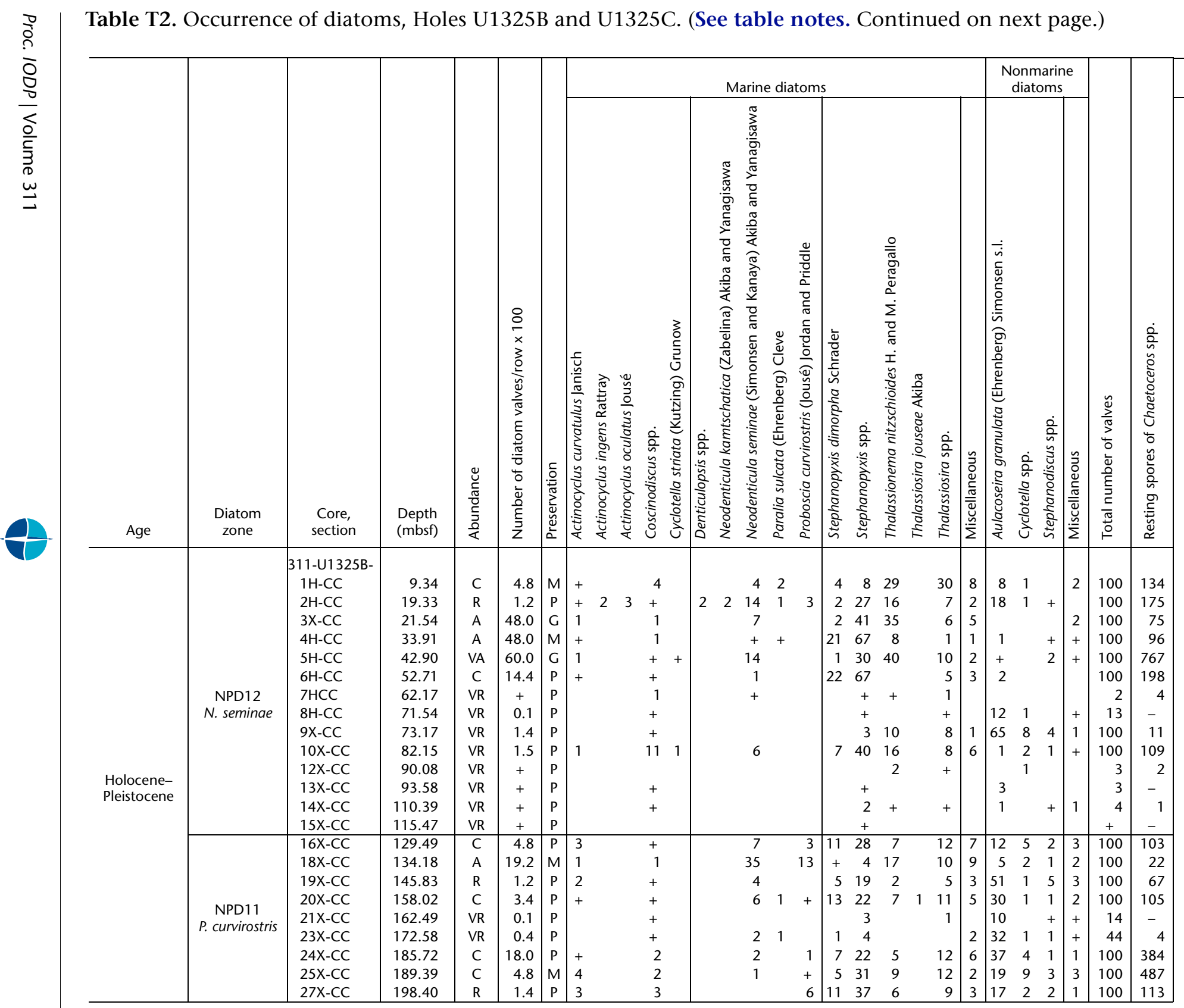

Marine/nonmarine diatoms ratio

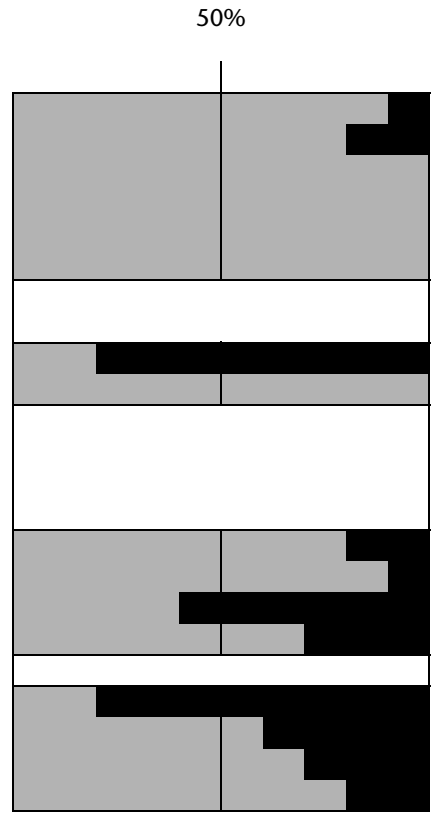




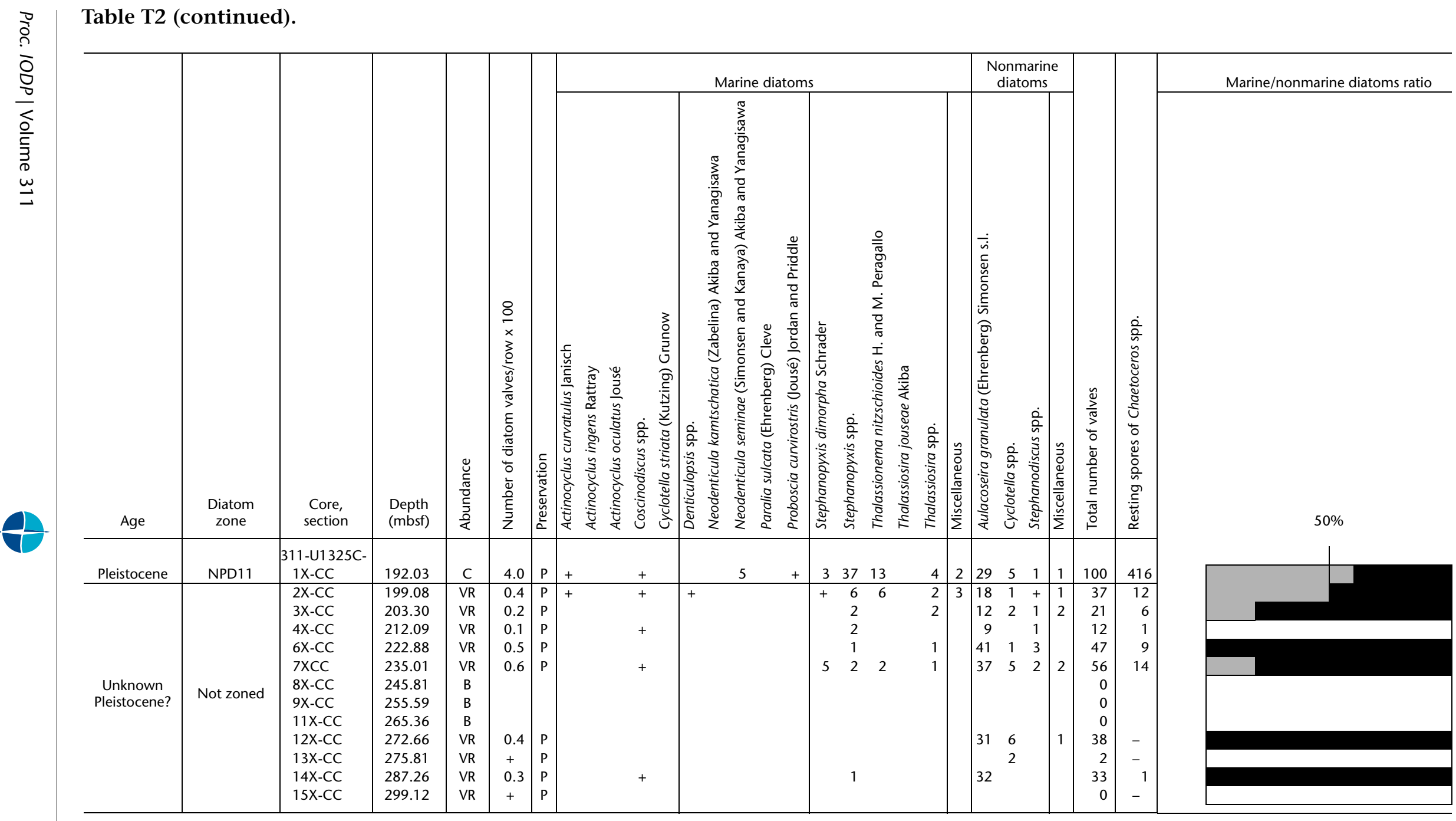

Notes: Abundance: $\mathrm{VA}=$ very abundant, $\mathrm{A}=$ abundant $\mathrm{C}=$ common, $\mathrm{R}=$ rare, $\mathrm{VR}=$ very rare, $\mathrm{B}=$ barren. Preservation: $\mathrm{G}=$ good, $\mathrm{M}=\mathrm{moderate}, \mathrm{P}=$ poor. $+=<1 \%$ and $/$ or valve fragments, $-=$ Chaetoceros spp. resting spores not present. 


\begin{tabular}{|c|c|c|c|c|c|c|c|c|c|c|c|c|c|c|c|c|c|c|c|}
\hline \multirow{2}{*}{$\begin{array}{l}\text { Core, section, } \\
\text { interval }(\mathrm{cm})\end{array}$} & \multirow{2}{*}{$\begin{array}{l}\text { Depth } \\
\text { (mbsf) }\end{array}$} & \multirow{2}{*}{$\begin{array}{l}\text { Volume } \\
(\mathrm{mL})\end{array}$} & \multirow[b]{2}{*}{$\mathrm{pH}$} & \multirow{2}{*}{$\begin{array}{l}\text { Alkalinity } \\
(\mathrm{mM})\end{array}$} & \multirow[b]{2}{*}{ Salinity } & \multirow{2}{*}{$\begin{array}{c}\mathrm{Cl} \\
(\mathrm{mM})\end{array}$} & \multirow{2}{*}{$\begin{array}{c}\mathrm{SO}_{4} \\
(\mathrm{mM})\end{array}$} & \multirow{2}{*}{$\begin{array}{l}\mathrm{PO}_{4} \\
(\mu \mathrm{M})\end{array}$} & \multirow{2}{*}{$\begin{array}{l}\mathrm{NH}_{4} \\
(\mathrm{mM})\end{array}$} & \multirow{2}{*}{$\begin{array}{c}\mathrm{H}_{4} \mathrm{SiO}_{4} \\
(\mu \mathrm{M})\end{array}$} & \multicolumn{4}{|c|}{ Cations (mM) } & \multirow[b]{2}{*}{$\mathrm{Mg} / \mathrm{Ca}$} & & race eler & ents $(\mu \mathrm{N}$ & \\
\hline & & & & & & & & & & & $\mathrm{Na}$ & $\mathrm{K}$ & $\mathrm{Mg}$ & $\mathrm{Ca}$ & & $\mathrm{Sr}$ & $\mathrm{Li}$ & B & $\mathrm{Ba}$ \\
\hline 311-U1325B- & & & & & & & & & & & & & & & & & & & \\
\hline $1 \mathrm{H}-1,65-80$ & 0.7 & 60.0 & 7.86 & 17.5 & 33.5 & 548.0 & 14.9 & 60.6 & 1.0 & 693.1 & 451.0 & 11.6 & 45.7 & 5.6 & 8.2 & 77.7 & 14.7 & 594.4 & 3.2 \\
\hline $1 \mathrm{H}-1,135-150$ & 1.4 & 60.0 & 7.90 & 30.6 & 33.0 & 558.0 & 1.1 & 93.4 & 1.7 & 655.1 & 434.8 & 10.5 & 42.5 & 2.5 & 17.1 & 79.2 & 9.8 & 668.3 & 53.9 \\
\hline $1 \mathrm{H}-2,65-80$ & 2.2 & 65.0 & 7.85 & 32.7 & 33.5 & 558.6 & 0.1 & 105.9 & 1.9 & 649.7 & 439.7 & 10.6 & 42.8 & 2.3 & 18.6 & 78.2 & 8.7 & 678.4 & 50.3 \\
\hline $1 \mathrm{H}-2,135-150$ & 2.9 & 54.0 & 7.83 & 34.1 & 33.5 & 558.0 & 0.0 & 100.6 & 2.0 & 608.5 & 445.2 & 10.7 & 45.1 & 2.6 & 17.1 & 77.0 & 8.6 & 655.3 & 45.9 \\
\hline $1 \mathrm{H}-3,60-75$ & 3.7 & 49.0 & 7.88 & 35.5 & 33.5 & 559.0 & 0.4 & 105.1 & 2.2 & 565.1 & 442.8 & 10.8 & 45.3 & 2.5 & 18.2 & 77.1 & 9.3 & 601.2 & 45.9 \\
\hline $1 \mathrm{H}-3,135-150$ & 4.4 & 54.0 & 7.81 & 36.6 & 33.5 & 560.5 & 0.0 & 124.3 & 3.3 & 627.3 & 437.5 & 10.3 & 43.8 & 2.5 & 17.6 & 77.1 & 9.6 & 644.0 & 41.7 \\
\hline $1 \mathrm{H}-3,135-150$ & 4.4 & 4.0 & - & - & 33.8 & 562.5 & 0.1 & 101.8 & 2.6 & 593.5 & 435.8 & 10.6 & 43.1 & 3.3 & 13.2 & 77.4 & 10.0 & 595.2 & 44.8 \\
\hline $1 \mathrm{H}-4,65-80$ & 5.2 & 56.5 & 7.85 & 38.3 & 33.8 & 563.0 & 0.0 & 135.1 & 2.5 & 711.8 & 433.8 & 10.5 & 44.5 & 2.6 & 17.3 & 77.1 & 9.6 & 681.7 & 39.2 \\
\hline $1 \mathrm{H}-4,135-150$ & 5.9 & 58.0 & 7.85 & 38.6 & 33.8 & 564.0 & 0.0 & 117.6 & 2.6 & 697.5 & 435.2 & 10.5 & 43.8 & 3.0 & 14.6 & 77.1 & 9.8 & 679.0 & 37.7 \\
\hline $1 \mathrm{H}-5,65-80$ & 6.7 & 66.5 & 7.82 & 39.4 & 34.0 & 565.0 & 0.1 & 111.3 & 2.7 & 677.4 & 427.5 & 10.0 & 42.5 & 2.6 & 16.1 & 76.9 & 10.0 & 678.0 & 35.5 \\
\hline $1 \mathrm{H}-5,135-150$ & 7.4 & 40.0 & 7.74 & 40.4 & 34.0 & 566.4 & 0.1 & 75.6 & 2.8 & 644.9 & 434.5 & 10.5 & 44.7 & 2.8 & 16.2 & 77.8 & 10.1 & 671.5 & 34.8 \\
\hline $1 \mathrm{H}-6,65-80$ & 8.2 & 45.0 & 7.84 & 41.9 & 34.2 & 568.0 & 0.1 & 65.9 & 3.0 & 574.3 & 405.7 & 9.6 & 41.3 & 2.6 & 15.7 & 78.5 & 9.6 & 637.0 & 34.3 \\
\hline $1 \mathrm{H}-6,135-150$ & 8.9 & 38.0 & 7.79 & 42.0 & 34.2 & 568.0 & 0.1 & 85.1 & 3.0 & 689.5 & 435.2 & 10.5 & 46.3 & 2.9 & 16.2 & 79.3 & 9.6 & 701.4 & 31.7 \\
\hline $2 \mathrm{H}-2,135-150$ & 12.2 & 9.0 & - & - & 34.7 & 571.8 & 0.0 & 52.6 & 3.3 & 523.3 & 432.5 & 10.6 & 47.4 & 3.1 & 15.2 & 84.9 & 9.4 & 633.6 & 31.0 \\
\hline $2 \mathrm{H}-6,135-150$ & 18.2 & 40.0 & 7.86 & 46.2 & 35.0 & 574.8 & 0.1 & 80.6 & 3.5 & 676.0 & 437.2 & 10.3 & 47.0 & 3.0 & 15.9 & 84.8 & 8.9 & 729.0 & 41.6 \\
\hline $4 \mathrm{H}-2,135-150$ & 26.7 & 58.0 & 7.95 & 52.9 & 35.7 & 580.7 & 0.0 & 120.6 & 3.9 & 746.4 & 448.0 & 11.1 & 48.1 & 2.3 & 21.3 & 83.3 & 13.1 & 710.5 & 107.4 \\
\hline $4 \mathrm{H}-5,135-150$ & 31.2 & 52.0 & 7.89 & 46.2 & 35.7 & 581.7 & 0.1 & - & 3.7 & 836.1 & 459.3 & 11.6 & 48.6 & 2.2 & 22.3 & 84.2 & 12.9 & 736.2 & 101.3 \\
\hline $5 \mathrm{H}-2,127-142$ & 36.3 & 60.0 & 7.78 & 42.4 & 35.7 & 590.0 & 0.2 & 117.6 & 3.6 & 643.1 & 444.2 & 10.3 & 47.8 & 1.7 & 28.9 & 81.0 & 12.5 & 611.7 & 79.0 \\
\hline $5 \mathrm{H}-5,135-150$ & 40.8 & 58.0 & 7.83 & 40.4 & 35.5 & 595.0 & 0.0 & 112.6 & 3.5 & 792.7 & 412.8 & 9.4 & 43.5 & 1.8 & 24.7 & 83.7 & 13.0 & 625.6 & 74.4 \\
\hline $6 \mathrm{H}-2,135-150$ & 45.9 & 50.0 & 7.81 & 36.9 & 35.5 & 597.5 & 0.0 & 83.4 & 3.3 & 772.9 & 453.0 & 9.8 & 44.8 & 2.6 & 17.1 & 85.5 & 12.0 & 511.5 & 43.4 \\
\hline $6 \mathrm{H}-5,135-150$ & 50.4 & 40.0 & 7.94 & 37.1 & 35.7 & 591.6 & 0.0 & 85.1 & 3.0 & 843.0 & 454.4 & 9.8 & 45.2 & 1.9 & 23.5 & 86.3 & 15.3 & 593.7 & 54.9 \\
\hline 7H-2, $135-150$ & 55.4 & 35.0 & 7.92 & 36.8 & 35.7 & 599.0 & 0.0 & 68.4 & 3.2 & 659.6 & 461.7 & 9.5 & 42.8 & 3.4 & 12.6 & 87.3 & 9.2 & 517.7 & 32.3 \\
\hline 7H-5, 135-150 & 59.9 & 30.0 & 7.97 & 34.3 & 35.5 & 593.0 & 0.0 & 38.1 & 3.4 & 513.6 & 448.5 & 9.7 & 41.6 & 3.3 & 12.4 & 83.0 & 8.3 & 480.5 & 31.9 \\
\hline $8 \mathrm{H}-3,125-150$ & 66.1 & 40.0 & - & - & 36.0 & 599.0 & 0.0 & 44.3 & 3.8 & 426.8 & 463.4 & 10.0 & 39.3 & 4.2 & 9.5 & 86.5 & 7.8 & 426.3 & 46.3 \\
\hline $8 \mathrm{H}-5,123-150$ & 69.1 & 58.0 & 7.93 & 34.0 & 36.0 & 600.5 & 0.0 & 48.4 & 3.5 & 557.2 & 465.3 & 9.6 & 38.8 & 4.3 & 9.0 & 88.7 & 8.9 & 470.1 & 47.9 \\
\hline $9 X-2,0-25$ & 73.0 & 54.0 & 8.00 & 35.9 & 36.0 & 602.0 & 0.1 & 51.8 & 3.9 & 609.8 & 490.6 & 10.2 & 41.3 & 4.3 & 9.7 & 95.7 & 16.0 & 463.1 & 58.2 \\
\hline $10 X-3,125-150$ & 77.2 & 26.0 & 7.88 & 37.5 & 35.8 & 593.6 & 0.0 & 77.6 & 4.0 & 718.0 & 491.7 & 9.8 & 42.3 & 4.0 & 10.5 & 88.0 & 12.1 & 486.4 & 41.6 \\
\hline $10 X-5,107-117$ & 79.9 & 4.0 & - & - & 35.8 & 600.5 & 0.0 & 41.8 & 4.2 & 674.0 & 489.9 & 10.3 & 42.1 & 4.2 & 10.0 & 87.6 & 11.4 & 392.9 & 40.4 \\
\hline $10 X-5,121-130$ & 80.1 & 12.0 & - & - & 33.8 & 577.3 & 1.2 & 41.3 & 4.2 & 561.7 & 473.2 & 10.4 & 40.5 & 3.7 & 11.0 & 80.3 & 12.2 & 415.0 & 34.7 \\
\hline $10 X-5,121-130$ & 80.1 & 3.0 & - & - & 30.5 & 515.0 & 2.6 & - & 3.9 & - & - & - & - & - & - & - & - & - & - \\
\hline $10 X-7,31-41$ & 82.0 & 27.0 & 8.04 & 35.6 & 35.5 & 598.4 & 0.2 & 32.3 & 4.6 & 585.0 & 484.8 & 10.7 & 40.7 & 3.9 & 10.5 & 86.5 & 11.5 & 442.6 & 30.3 \\
\hline $12 X-2,125-150$ & 87.3 & 14.0 & - & - & 36.2 & 594.5 & 0.0 & - & 4.0 & - & - & - & - & - & - & - & - & - & - \\
\hline $12 X-4,68-93$ & 89.7 & 19.0 & - & - & 35.8 & 600.9 & 0.0 & 49.3 & 4.2 & 476.9 & 499.3 & 10.9 & 42.1 & 4.2 & 10.1 & 86.0 & 8.5 & 414.2 & 30.2 \\
\hline $14 \mathrm{X}-2,125-150$ & 105.2 & 54.0 & 7.76 & 36.4 & 35.8 & 597.9 & 0.4 & 78.4 & 4.8 & 877.5 & 495.5 & 10.2 & 40.5 & 4.2 & 9.7 & 91.5 & 13.1 & 494.0 & 50.8 \\
\hline $14 X-5,125-133$ & 109.6 & 15.0 & - & - & 27.0 & 460.0 & 3.5 & - & 5.0 & - & 451.4 & 9.6 & 37.0 & 4.1 & 9.0 & - & - & - & - \\
\hline $14 X-5,125-133$ & 109.6 & 4.0 & - & - & 34.5 & 581.7 & 0.1 & - & - & - & - & - & - & - & - & - & - & - & - \\
\hline $14 X-6,0-25$ & 109.8 & 29.0 & - & - & 35.8 & 598.4 & 0.0 & 45.1 & 5.1 & 556.2 & 495.2 & 10.6 & 40.5 & 4.5 & 8.9 & 92.7 & 9.6 & 455.3 & 65.0 \\
\hline $15 X-2,120-150$ & 114.6 & 24.0 & 8.05 & 33.3 & 35.0 & 596.0 & 0.9 & 48.4 & 5.4 & 366.6 & 499.6 & 10.9 & 39.6 & 4.9 & 8.1 & 90.9 & 11.7 & 379.4 & 79.5 \\
\hline $15 \times-3,0-14$ & 114.8 & 10.0 & - & - & 35.0 & 583.6 & 0.4 & - & 5.6 & 318.4 & 477.3 & 10.4 & 37.5 & 4.6 & 8.1 & 86.4 & 11.3 & 351.0 & 77.0 \\
\hline $15 X-3,0-14$ & 114.8 & 0.5 & - & - & 27.0 & 457.5 & 0.5 & - & 4.6 & - & - & - & - & - & - & - & - & - & - \\
\hline $16 \mathrm{X}-2,120-150$ & 124.2 & 49.0 & 7.70 & 32.8 & 36.0 & 593.5 & 0.6 & 82.3 & 5.5 & 619.3 & 499.9 & 10.2 & 39.5 & 4.7 & 8.4 & 82.6 & 20.9 & 364.2 & 96.6 \\
\hline $16 X-4,25-35$ & 126.1 & 15.0 & - & - & 34.2 & 577.7 & 0.1 & 52.9 & 5.8 & - & 472.1 & 10.1 & 36.4 & 4.4 & 8.3 & - & - & - & - \\
\hline $16 \mathrm{X}-4,25-35$ & 126.1 & 1.0 & - & - & 22.5 & 379.6 & 3.9 & - & 3.9 & - & - & - & - & - & - & - & - & - & - \\
\hline $16 \mathrm{X}-6,120-150$ & 128.0 & 38.0 & - & - & 35.5 & 603.4 & 0.9 & 64.3 & 5.8 & 811.4 & 494.3 & 10.3 & 38.0 & 4.5 & 8.4 & 87.2 & 22.1 & 446.7 & 85.5 \\
\hline $18 X-1,140-150$ & 132.4 & 8.0 & - & - & 32.5 & 548.6 & 0.0 & 41.8 & 5.7 & 707.0 & 449.5 & 9.7 & 32.9 & 4.1 & 8.0 & 77.7 & 21.0 & 405.6 & 69.3 \\
\hline $18 X-2,126-156$ & 133.8 & 22.0 & 7.87 & 31.2 & 35.7 & 598.4 & 0.0 & 55.9 & 6.3 & 840.0 & 494.1 & 10.5 & 36.8 & 4.8 & 7.6 & 88.0 & 22.0 & 440.2 & 71.8 \\
\hline $19 X-3,21-30$ & 143.8 & 6.0 & - & - & 27.7 & 469.3 & 2.3 & 17.6 & 5.5 & - & - & - & - & - & - & - & - & - & - \\
\hline $19 X-3,21-30$ & 143.8 & 4.0 & - & - & 35.0 & 595.5 & 0.4 & - & 6.8 & - & - & - & - & - & - & - & - & - & - \\
\hline $19 X-5,31-53$ & 145.7 & 6.0 & - & - & 35.7 & 596.0 & 0.0 & 26.8 & 6.5 & 698.7 & 534.4 & 11.6 & 38.6 & 5.5 & 7.0 & 87.7 & 18.6 & 456.5 & 55.7 \\
\hline
\end{tabular}


Table T3 (continued).

\begin{tabular}{|c|c|c|c|c|c|c|c|c|c|c|c|c|c|c|c|c|c|c|c|}
\hline \multirow{2}{*}{$\begin{array}{l}\text { Core, section, } \\
\text { interval }(\mathrm{cm})\end{array}$} & \multirow{2}{*}{$\begin{array}{l}\text { Depth } \\
\text { (mbsf) }\end{array}$} & \multirow{2}{*}{$\begin{array}{l}\text { Volume } \\
(\mathrm{mL})\end{array}$} & \multirow[b]{2}{*}{$\mathrm{pH}$} & \multirow{2}{*}{$\begin{array}{l}\text { Alkalinity } \\
(\mathrm{mM})\end{array}$} & \multirow[b]{2}{*}{ Salinity } & \multirow{2}{*}{$\begin{array}{c}\mathrm{Cl} \\
(\mathrm{mM})\end{array}$} & \multirow{2}{*}{$\begin{array}{c}\mathrm{SO}_{4} \\
(\mathrm{mM})\end{array}$} & \multirow{2}{*}{$\begin{array}{l}\mathrm{PO}_{4} \\
(\mu \mathrm{M})\end{array}$} & \multirow{2}{*}{$\begin{array}{l}\mathrm{NH}_{4} \\
(\mathrm{mM})\end{array}$} & \multirow{2}{*}{$\begin{array}{c}\mathrm{H}_{4} \mathrm{SiO}_{4} \\
(\mu \mathrm{M})\end{array}$} & \multicolumn{4}{|c|}{ Cations (mM) } & \multirow[b]{2}{*}{$\mathrm{Mg} / \mathrm{Ca}$} & \multicolumn{4}{|c|}{ Trace elements $(\mu \mathrm{M})$} \\
\hline & & & & & & & & & & & $\mathrm{Na}$ & K & $\mathrm{Mg}$ & $\mathrm{Ca}$ & & $\mathrm{Sr}$ & $\mathrm{Li}$ & B & $\mathrm{Ba}$ \\
\hline $20 \times-3,45-64$ & 153.7 & 4.0 & - & - & 26.0 & 596.5 & 6.5 & 18.4 & 6.8 & - & 493.6 & 10.5 & 33.4 & 5.3 & 6.3 & - & - & - & - \\
\hline $20 \times-3,45-64$ & 153.7 & 8.0 & - & - & 35.2 & 438.2 & 0.2 & - & 5.0 & - & - & - & - & - & - & - & - & - & - \\
\hline $20 X-5,120-150$ & 156.7 & 8.0 & - & - & 35.5 & 599.4 & 0.0 & 24.3 & 7.2 & 621.5 & 488.1 & 10.3 & 33.1 & 5.3 & 6.3 & 85.5 & 14.7 & 403.4 & 35.0 \\
\hline $21 X-1,37-51$ & 160.2 & 6.0 & - & - & 35.0 & 598.9 & 0.6 & 20.1 & 7.1 & - & - & - & - & - & - & - & - & - & - \\
\hline $21 X-1,37-51$ & 160.2 & 4.0 & - & - & 20.3 & 351.5 & 4.8 & - & 4.0 & - & - & - & - & - & - & - & - & - & - \\
\hline $21 X-2,120-150$ & 161.7 & 7.0 & 7.89 & 23.5 & 35.5 & 605.3 & 0.0 & 15.4 & 6.9 & 554.7 & 496.0 & 10.2 & 33.2 & 5.7 & 5.8 & 87.6 & 14.0 & 351.4 & 32.4 \\
\hline $23 X-1,120-150$ & 171.8 & 18.0 & 7.74 & 22.5 & 35.5 & 602.9 & 0.0 & 20.1 & 7.2 & 646.4 & 490.9 & 9.4 & 32.4 & 6.0 & 5.4 & 86.9 & 11.9 & 384.4 & 25.8 \\
\hline $24 \mathrm{X}-2,0-11$ & 180.4 & 1.5 & - & - & 21.0 & 379.1 & 6.7 & - & 5.3 & 579.2 & 488.5 & 10.0 & 27.7 & 6.9 & 4.0 & 86.8 & 14.8 & 346.7 & 24.1 \\
\hline $24 \mathrm{X}-2,0-11$ & 180.4 & 2.0 & - & - & 34.0 & 592.0 & 0.0 & - & 8.7 & - & - & - & - & - & - & - & - & - & - \\
\hline $24 X-3,120-150$ & 183.1 & 18.0 & 7.83 & 18.4 & 34.2 & 596.5 & 0.0 & 15.9 & 8.3 & 708.5 & 478.8 & 9.1 & 28.0 & 6.8 & 4.1 & 88.7 & 14.7 & 372.4 & 24.1 \\
\hline $24 X-4,0-14$ & 183.3 & 6.0 & - & - & 33.5 & 598.4 & 0.0 & 12.9 & 8.1 & 687.2 & 483.2 & 9.5 & 28.2 & 6.3 & 4.5 & 88.8 & 15.5 & 366.9 & 23.5 \\
\hline $24 X-4,0-14$ & 183.3 & 4.0 & - & - & 20.0 & 352.5 & 4.9 & - & 6.2 & - & - & - & - & - & - & - & - & - & - \\
\hline $24 X-5,112-145$ & 185.6 & 22.0 & 7.77 & 17.5 & 33.5 & 584.6 & 0.0 & 14.3 & 8.5 & 675.0 & 477.7 & 9.0 & 26.8 & 6.9 & 3.9 & 86.8 & 14.4 & 344.0 & 23.6 \\
\hline \multicolumn{20}{|l|}{ 311-U1325C- } \\
\hline $1 \mathrm{X}-1,120-150$ & 190.2 & 10.0 & 7.81 & 18.1 & 33.8 & 598.0 & 0.2 & 16.2 & 8.2 & 745.2 & 472.4 & 8.4 & 27.2 & 7.9 & 3.4 & 91.5 & 14.4 & 402.5 & 25.3 \\
\hline $1 \mathrm{X}-2,141-151$ & 191.8 & 6.0 & - & - & 18.5 & 314.0 & 2.5 & 5.3 & 4.3 & 308.2 & 307.2 & 5.1 & 16.4 & 4.0 & 4.1 & 47.3 & 9.9 & 221.8 & 12.9 \\
\hline $1 \mathrm{X}-2,141-151$ & 191.8 & 3.0 & - & - & 33.8 & 585.0 & 0.8 & - & 7.6 & - & - & - & - & - & - & - & - & - & - \\
\hline $2 X-1,0-43$ & 198.6 & 5.0 & - & - & 28.0 & 474.0 & 16.2 & 9.5 & 6.0 & 393.5 & 381.5 & 6.7 & 28.2 & 6.7 & 4.2 & 75.0 & 11.6 & 319.1 & 16.6 \\
\hline $2 X-1,0-43$ & 198.6 & 6.0 & - & - & 33.0 & 572.0 & 0.3 & - & 9.2 & 689.3 & 465.0 & 8.2 & 23.9 & 7.6 & 3.1 & 92.3 & 11.3 & 385.2 & 24.6 \\
\hline $4 \mathrm{X}-1,112-124$ & 209.2 & 11.0 & - & - & 17.7 & 305.0 & 4.1 & 2.8 & 5.0 & 245.7 & 250.7 & 4.3 & 13.0 & 3.7 & 3.5 & 39.5 & 8.0 & 166.3 & 10.5 \\
\hline $4 X-3,0-79$ & 210.5 & 12.0 & 8.06 & 14.3 & 32.3 & 565.0 & 0.3 & 5.3 & 9.6 & 532.2 & 461.1 & 8.6 & 23.5 & 7.6 & 3.1 & 86.7 & 8.9 & 341.1 & 24.7 \\
\hline $6 \mathrm{X}-1,0-29$ & 218.7 & - & - & - & - & - & - & - & & - & - & - & - & - & - & - & - & - & - \\
\hline $6 X-3,88-112$ & 221.4 & 2.0 & - & - & 19.0 & 335.0 & 7.9 & 4.5 & 8.6 & 451.2 & 463.6 & 8.9 & 27.3 & 7.9 & 3.5 & 83.0 & 10.2 & 252.8 & 21.7 \\
\hline $6 X-3,88-112$ & 221.4 & 9.0 & 7.99 & 13.3 & 31.7 & 574.0 & 5.2 & 1.2 & 5.8 & - & - & - & - & - & - & - & - & - & - \\
\hline $7 X-2,0-50$ & 229.0 & 20.0 & 7.93 & 16.3 & 33.5 & 589.7 & 0.4 & 6.2 & 8.5 & 479.7 & 476.6 & 8.4 & 27.5 & 8.4 & 3.3 & 93.4 & 9.4 & 316.1 & 23.0 \\
\hline $7 X-4,69-79$ & 231.9 & 9.0 & - & - & 33.5 & 598.0 & 0.7 & 6.2 & 8.5 & 493.3 & 467.6 & 8.5 & 27.1 & 8.3 & 3.3 & 95.5 & 10.6 & 256.1 & 27.3 \\
\hline $7 X-4,69-79$ & 231.9 & 5.0 & - & - & 26.5 & 489.0 & 4.2 & 4.5 & 10.2 & - & - & - & - & - & - & - & - & - & - \\
\hline $8 X-2,62-85$ & 239.0 & 26.0 & 8.09 & 9.7 & 25.5 & 457.6 & 5.7 & 2.8 & 9.1 & 235.2 & 378.8 & 6.2 & 20.8 & 6.0 & 3.5 & 68.1 & 6.7 & 225.8 & 13.7 \\
\hline $8 X-4,0-50$ & 240.9 & 27.0 & 7.67 & 15.3 & 34.0 & 588.7 & 0.0 & 5.3 & 11.2 & 359.5 & 460.2 & 8.0 & 24.2 & 7.8 & 3.1 & 96.3 & 7.5 & 364.8 & 20.0 \\
\hline $9 \mathrm{X}-2,100-150$ & 249.3 & 40.0 & 7.86 & 15.0 & 33.8 & 585.2 & 0.3 & 6.2 & 12.6 & 459.9 & 467.1 & 7.6 & 24.8 & 8.5 & 2.9 & 104.7 & 5.9 & 417.5 & 18.4 \\
\hline $9 \mathrm{X}-4,111-128$ & 252.2 & 10.0 & 8.00 & 13.7 & 33.8 & 594.6 & 3.3 & 6.2 & 11.6 & 241.0 & 477.3 & 8.9 & 26.4 & 8.1 & 3.3 & 100.4 & 8.5 & 334.6 & 19.4 \\
\hline $10 \mathrm{P}-1,6-16$ & 256.2 & 10.0 & - & - & 33.7 & 567.9 & 8.8 & - & - & - & - & - & - & - & - & - & - & - & - \\
\hline $10 \mathrm{P}-1,60-70$ & 256.8 & 35.0 & - & - & 34.5 & 601.5 & 1.5 & - & - & - & - & - & - & - & - & - & - & - & - \\
\hline $11 X-2,105-150$ & 259.9 & 24.0 & 7.82 & 17.1 & 34.8 & 601.5 & 0.5 & - & 12.9 & 453.6 & 464.5 & 8.1 & 25.6 & 8.9 & 2.9 & 116.0 & 6.2 & 444.2 & 18.1 \\
\hline $11 X-5,0-45$ & 263.3 & 30.0 & 7.97 & 18.4 & 34.8 & 601.5 & 0.9 & 10.3 & 13.6 & 377.8 & 468.9 & 8.4 & 24.8 & 8.7 & 2.8 & 114.7 & 6.0 & 406.2 & 18.5 \\
\hline $12 X-3,0-45$ & 268.9 & 26.0 & 7.83 & 13.4 & 34.5 & 601.8 & 0.7 & - & 13.3 & 542.5 & 483.0 & 8.6 & 26.5 & 9.2 & 2.9 & 117.4 & 7.1 & 422.3 & 19.5 \\
\hline $14 \mathrm{X}-2,0-80$ & 286.3 & 12.0 & - & - & 35.0 & 601.2 & 1.7 & - & 13.5 & 503.7 & 471.7 & 9.2 & 25.0 & 8.5 & 2.9 & 109.3 & 11.1 & 431.6 & 25.6 \\
\hline $15 X-3,0-134$ & 297.8 & 21.0 & - & - & 34.7 & 601.5 & 0.5 & - & 15.8 & 494.4 & 478.3 & 9.6 & 24.7 & 8.5 & 2.9 & 112.0 & 17.6 & 418.2 & 27.4 \\
\hline $15 X-3,0-134$ & 297.8 & 8.0 & - & - & 34.7 & 601.0 & 0.4 & 7.8 & 15.4 & 549.5 & 477.4 & 9.5 & 24.0 & 8.3 & 2.9 & 113.4 & 18.2 & 424.0 & 28.3 \\
\hline $15 X-3,0-134$ & 297.8 & 6.0 & - & - & 35.0 & 601.0 & 0.2 & 5.3 & 16.1 & - & - & - & - & - & - & - & - & - & - \\
\hline 311-U1325D- & & & & & & & & & & & & & & & & & & & \\
\hline $1 \mathrm{H}-1,140-150$ & 1.4 & 60.0 & 7.58 & 13.4 & 34.2 & 554.5 & 19.6 & - & - & - & - & - & - & - & - & - & - & - & - \\
\hline $1 \mathrm{H}-2,140-151$ & 2.4 & 55.0 & 7.70 & 21.7 & 33.7 & 556.5 & 10.9 & - & - & - & - & - & - & - & - & - & - & - & - \\
\hline $1 \mathrm{H}-3,130-140$ & 4.3 & 40.0 & 7.81 & 29.5 & 33.5 & 555.5 & 2.1 & - & - & - & - & - & - & - & - & - & - & - & - \\
\hline $1 \mathrm{H}-3,140-153$ & 4.4 & 40.0 & 7.82 & 29.5 & 33.5 & 556.0 & 2.0 & - & - & - & - & - & - & - & - & - & - & - & - \\
\hline BW & & - & - & - & 34.5 & 558.0 & 28.9 & - & - & 157.6 & 457.4 & 10.4 & 50.4 & 10.2 & 4.9 & - & - & - & - \\
\hline
\end{tabular}

Notes: BW $=$ bottom water. $-=$ no data. 
Table T4. Concentrations of solutes corrected for drill fluid contamination in interstitial waters, Holes U1325B, U1325C and U1325D. (See table notes. Continued on next page.)

\begin{tabular}{|c|c|c|c|c|c|c|c|c|c|c|c|c|c|c|c|c|c|c|c|}
\hline \multirow{2}{*}{$\begin{array}{l}\text { Core, section, } \\
\text { interval }(\mathrm{cm})\end{array}$} & \multirow{2}{*}{$\begin{array}{l}\text { Depth } \\
\text { (mbsf) }\end{array}$} & \multirow{2}{*}{$\begin{array}{l}\text { Volume } \\
(\mathrm{mL})\end{array}$} & \multirow[b]{2}{*}{$\mathrm{pH}$} & \multirow{2}{*}{$\begin{array}{l}\text { Alkalinity } \\
(\mathrm{mM})\end{array}$} & \multirow[b]{2}{*}{ Salinity } & \multirow{2}{*}{$\begin{array}{c}\mathrm{Cl} \\
(\mathrm{mM})\end{array}$} & \multirow{2}{*}{$\begin{array}{l}\mathrm{SO}_{4} \\
(\mathrm{mM})\end{array}$} & \multirow{2}{*}{$\begin{array}{l}\mathrm{PO}_{4} \\
(\mu \mathrm{M})\end{array}$} & \multirow{2}{*}{$\begin{array}{l}\mathrm{NH}_{4} \\
(\mathrm{mM})\end{array}$} & \multirow{2}{*}{$\begin{array}{c}\mathrm{H}_{4} \mathrm{SiO}_{4} \\
(\mu \mathrm{M})\end{array}$} & \multicolumn{4}{|c|}{ Cations (mM) } & \multirow[b]{2}{*}{$\mathrm{Mg} / \mathrm{Ca}$} & \multicolumn{4}{|c|}{ Trace elements $(\mu \mathrm{M})$} \\
\hline & & & & & & & & & & & $\mathrm{Na}$ & $\mathrm{K}$ & $\mathrm{Mg}$ & $\mathrm{Ca}$ & & $\mathrm{Sr}$ & $\mathrm{Li}$ & B & $\mathrm{Ba}$ \\
\hline 311-U1325B- & & & & & & & & & & & & & & & & & & & \\
\hline $1 \mathrm{H}-1,65-80$ & 0.7 & 60.0 & 7.86 & 17.5 & 33.5 & 548 & 14.9 & 60.6 & 1.0 & 693.1 & 451.0 & 11.6 & 45.7 & 5.6 & 8.2 & 77.7 & 14.7 & 594.4 & 3.2 \\
\hline $1 \mathrm{H}-1,135-150$ & 1.4 & 60.0 & 7.9 & 30.6 & 33.0 & 558 & 1.1 & 93.4 & 1.7 & 655.1 & 434.8 & 10.5 & 42.5 & 2.5 & 17.1 & 79.2 & 9.8 & 668.3 & 53.9 \\
\hline $1 \mathrm{H}-2,65-80$ & 2.2 & 65.0 & 7.85 & 32.7 & 33.5 & 559 & 0.1 & 105.9 & 1.9 & 649.7 & 439.7 & 10.6 & 42.8 & 2.3 & 18.6 & 78.2 & 8.7 & 678.4 & 50.3 \\
\hline $1 \mathrm{H}-2,135-150$ & 2.9 & 54.0 & 7.83 & 34.1 & 33.5 & 558 & 0.0 & 100.6 & 2.0 & 608.5 & 445.2 & 10.7 & 45.1 & 2.6 & 17.1 & 77.0 & 8.6 & 655.3 & 45.9 \\
\hline $1 \mathrm{H}-3,60-75$ & 3.7 & 49.0 & 7.88 & 35.5 & 33.5 & 559 & 0.0 & 105.1 & 2.2 & 565.1 & 442.8 & 10.8 & 45.3 & 2.5 & 18.2 & 77.1 & 9.3 & 601.2 & 45.9 \\
\hline $1 \mathrm{H}-3,135-150$ & 4.4 & 54.0 & 7.81 & 36.6 & 33.5 & 561 & 0.0 & 124.3 & 3.3 & 627.3 & 437.5 & 10.3 & 43.8 & 2.5 & 17.6 & 77.1 & 9.6 & 644.0 & 41.7 \\
\hline $1 \mathrm{H}-3,135-150$ & 4.4 & 4.0 & - & - & 33.8 & 563 & 0.0 & 101.8 & 2.6 & 593.5 & 435.8 & 10.6 & 43.1 & 3.3 & 13.2 & 77.4 & 10.0 & 595.2 & 44.8 \\
\hline $1 \mathrm{H}-4,65-80$ & 5.2 & 56.5 & 7.85 & 38.3 & 33.8 & 563 & 0.0 & 135.1 & 2.5 & 711.8 & 433.8 & 10.5 & 44.5 & 2.6 & 17.3 & 77.1 & 9.6 & 681.7 & 39.2 \\
\hline $1 \mathrm{H}-4,135-150$ & 5.9 & 58.0 & 7.85 & 38.6 & 33.8 & 564 & 0.0 & 117.6 & 2.6 & 697.5 & 435.2 & 10.5 & 43.8 & 3.0 & 14.6 & 77.1 & 9.8 & 679.0 & 37.7 \\
\hline $1 \mathrm{H}-5,65-80$ & 6.7 & 66.5 & 7.82 & 39.4 & 34.0 & 565 & 0.0 & 111.3 & 2.7 & 677.4 & 427.5 & 10.0 & 42.5 & 2.6 & 16.1 & 76.9 & 10.0 & 678.0 & 35.5 \\
\hline $1 \mathrm{H}-5,135-150$ & 7.4 & 40.0 & 7.74 & 40.4 & 34.0 & 566 & 0.0 & 75.6 & 2.8 & 644.9 & 434.5 & 10.5 & 44.7 & 2.8 & 16.2 & 77.8 & 10.1 & 671.5 & 34.8 \\
\hline $1 \mathrm{H}-6,65-80$ & 8.2 & 45.0 & 7.84 & 41.9 & 34.2 & 568 & 0.0 & 65.9 & 3.0 & 574.3 & 405.7 & 9.6 & 41.3 & 2.6 & 15.7 & 78.5 & 9.6 & 637.0 & 34.3 \\
\hline $1 \mathrm{H}-6,135-150$ & 8.9 & 38.0 & 7.79 & 42.0 & 34.2 & 568 & 0.0 & 85.1 & 3.0 & 689.5 & 435.2 & 10.5 & 46.3 & 2.9 & 16.2 & 79.3 & 9.6 & 701.4 & 31.7 \\
\hline $2 \mathrm{H}-2,135-150$ & 12.2 & 9.0 & - & - & 34.7 & 572 & 0.0 & 52.6 & 3.3 & 523.3 & 432.5 & 10.6 & 47.4 & 3.1 & 15.2 & 84.9 & 9.4 & 633.6 & 31.0 \\
\hline $2 \mathrm{H}-6,135-150$ & 18.2 & 40.0 & 7.86 & 46.2 & 35.0 & 575 & 0.0 & 80.6 & 3.5 & 676.0 & 437.2 & 10.3 & 47.0 & 3.0 & 15.9 & 84.8 & 8.9 & 729.0 & 41.6 \\
\hline $4 \mathrm{H}-2,135-150$ & 26.7 & 58.0 & 7.95 & 52.9 & 35.7 & 581 & 0.0 & 120.6 & 3.9 & 746.4 & 448.0 & 11.1 & 48.1 & 2.3 & 21.3 & 83.3 & 13.1 & 710.5 & 107.4 \\
\hline $4 \mathrm{H}-5,135-150$ & 31.2 & 52.0 & 7.89 & 46.2 & 35.7 & 582 & 0.0 & - & 3.7 & 836.1 & 459.3 & 11.6 & 48.6 & 2.2 & 22.3 & 84.2 & 12.9 & 736.2 & 101.3 \\
\hline $5 \mathrm{H}-2,127-142$ & 36.3 & 60.0 & 7.78 & 42.4 & 35.7 & 590 & 0.0 & 117.6 & 3.6 & 643.1 & 444.2 & 10.3 & 47.8 & 1.7 & 28.9 & 81.0 & 12.5 & 611.7 & 79.0 \\
\hline $5 \mathrm{H}-5,135-150$ & 40.8 & 58.0 & 7.83 & 40.4 & 35.5 & 595 & 0.0 & 112.6 & 3.5 & 792.7 & 412.8 & 9.4 & 43.5 & 1.8 & 24.7 & 83.7 & 13.0 & 625.6 & 74.4 \\
\hline $6 \mathrm{H}-2,135-150$ & 45.9 & 50.0 & 7.81 & 36.9 & 35.5 & 598 & 0.0 & 83.4 & 3.3 & 772.9 & 453.0 & 9.8 & 44.8 & 2.6 & 17.1 & 85.5 & 12.0 & 511.5 & 43.4 \\
\hline $6 \mathrm{H}-5,135-150$ & 50.4 & 40.0 & 7.94 & 37.1 & 35.7 & 592 & 0.0 & 85.1 & 3.0 & 843.0 & 454.4 & 9.8 & 45.2 & 1.9 & 23.5 & 86.3 & 15.3 & 593.7 & 54.9 \\
\hline $7 \mathrm{H}-2,135-150$ & 55.4 & 35.0 & 7.92 & 36.8 & 35.7 & 599 & 0.0 & 68.4 & 3.2 & 659.6 & 461.7 & 9.5 & 42.8 & 3.4 & 12.6 & 87.3 & 9.2 & 517.7 & 32.3 \\
\hline 7H-5, 135-150 & 59.9 & 30.0 & 7.97 & 34.3 & 35.5 & 593 & 0.0 & 38.1 & 3.4 & 513.6 & 448.5 & 9.7 & 41.6 & 3.3 & 12.4 & 83.0 & 8.3 & 480.5 & 31.9 \\
\hline $8 \mathrm{H}-3,125-150$ & 66.1 & 40.0 & - & - & 36.0 & 599 & 0.0 & 44.3 & 3.8 & 426.8 & 463.4 & 10.0 & 39.3 & 4.2 & 9.5 & 86.5 & 7.8 & 426.3 & 46.3 \\
\hline $8 \mathrm{H}-5,123-150$ & 69.1 & 58.0 & 7.93 & 34.0 & 36.0 & 601 & 0.0 & 48.4 & 3.5 & 557.2 & 465.3 & 9.6 & 38.8 & 4.3 & 9.0 & 88.7 & 8.9 & 470.1 & 47.9 \\
\hline $9 X-2,0-25$ & 73.0 & 54.0 & 8.0 & 35.9 & 36.0 & 602 & 0.0 & 51.8 & 3.9 & 609.8 & 490.6 & 10.2 & 41.3 & 4.3 & 9.7 & 95.7 & 16.0 & 463.1 & 58.2 \\
\hline $10 X-3,125-150$ & 77.2 & 26.0 & 7.88 & 37.5 & 35.8 & 594 & 0.0 & 77.6 & 4.0 & 718.0 & 491.7 & 9.8 & 42.3 & 4.0 & 10.5 & 88.0 & 12.1 & 486.4 & 41.6 \\
\hline $10 X-5,107-117$ & 79.9 & 4.0 & - & - & 35.8 & 601 & 0.0 & 41.8 & 4.2 & 674.0 & 489.9 & 10.3 & 42.1 & 4.2 & 10.0 & 87.6 & 11.4 & 392.9 & 40.4 \\
\hline $10 X-5,121-130$ & 80.1 & 12.0 & - & - & 33.8 & 578 & 0.0 & 43.0 & 4.4 & 578.9 & 473.0 & 10.4 & 39.9 & 3.4 & 11.8 & 80.1 & 11.6 & 413.6 & 36.1 \\
\hline $10 X-5,121-130$ & 80.1 & 3.0 & - & - & 30.5 & 511 & 0.0 & - & 4.3 & - & - & - & - & - & - & - & - & - & - \\
\hline $10 X-7,31-41$ & 82.0 & 27.0 & 8.04 & 35.6 & 35.5 & 598 & 0.0 & 32.3 & 4.6 & 585.0 & 484.8 & 10.7 & 40.7 & 3.9 & 10.5 & 86.5 & 11.5 & 442.6 & 30.3 \\
\hline $12 X-2,125-150$ & 87.3 & 14.0 & - & - & 36.2 & 594 & 0.0 & - & 4.0 & - & - & - & - & - & - & - & - & - & - \\
\hline $12 X-4,68-93$ & 89.7 & 19.0 & - & - & 35.8 & 601 & 0.0 & 49.3 & 4.2 & 476.9 & 499.3 & 10.9 & 42.1 & 4.2 & 10.1 & 86.0 & 8.5 & 414.2 & 30.2 \\
\hline $14 \mathrm{X}-2,125-150$ & 105.2 & 54.0 & 7.76 & 36.8 & 35.8 & 598 & 0.0 & 79.4 & 4.9 & 886.4 & 495.7 & 10.2 & 40.4 & 4.1 & 9.8 & 91.5 & 13.0 & 494.5 & 51.4 \\
\hline $14 X-5,125-133$ & 109.6 & 15.0 & - & - & 26.0 & 447 & 0.0 & - & 5.6 & - & 447.6 & 9.5 & 34.7 & 3.2 & 10.7 & - & - & - & - \\
\hline $14 X-5,125-133$ & 109.6 & 4.0 & - & - & 34.5 & 582 & 0.0 & - & - & - & - & - & - & - & - & - & - & - & - \\
\hline $14 \mathrm{X}-6,0-25$ & 109.8 & 29.0 & - & - & 35.8 & 598 & 0.0 & 45.1 & 5.1 & 556.2 & 495.2 & 10.6 & 40.5 & 4.5 & 8.9 & 92.7 & 9.6 & 455.3 & 65.0 \\
\hline $15 X-2,120-150$ & 114.6 & 24.0 & 8.05 & 34.2 & 35.0 & 597 & 0.0 & 49.9 & 5.6 & 373.3 & 500.2 & 10.9 & 39.1 & 4.7 & 4.7 & 91.0 & 11.3 & 377.2 & 82.0 \\
\hline $15 X-3,0-14$ & 114.8 & 10.0 & - & - & 35.0 & 584 & 0.0 & - & 5.7 & 321.0 & 477.3 & 10.4 & 37.2 & 4.5 & 4.5 & 86.4 & 11.0 & 349.4 & 78.2 \\
\hline $15 X-3,0-14$ & 114.8 & 0.5 & - & - & 26.9 & 456 & 0.0 & - & 4.6 & - & - & - & - & - & - & - & - & - & - \\
\hline $16 X-2,120-150$ & 124.2 & 49.0 & 7.7 & 33.4 & 36.0 & 594 & 0.0 & 83.8 & 5.6 & 628.4 & 500.3 & 10.2 & 39.2 & 4.6 & 4.6 & 82.5 & 20.8 & 362.5 & 98.5 \\
\hline $16 X-4,25-35$ & 126.1 & 15.0 & - & - & 34.2 & 578 & 0.0 & 52.9 & 5.8 & - & 472.1 & 10.1 & 36.4 & 4.4 & 8.3 & - & - & - & - \\
\hline $16 \mathrm{X}-4,25-35$ & 126.1 & 1.0 & - & - & 20.7 & 352 & 0.0 & - & 4.5 & - & - & - & - & - & - & - & - & - & - \\
\hline $16 X-6,120-150$ & 128.0 & 38.0 & - & - & 35.5 & 605 & 0.0 & 66.3 & 6.0 & 832.4 & 494.8 & 10.3 & 37.5 & 4.3 & 8.7 & 87.2 & 21.9 & 446.6 & 88.2 \\
\hline $18 \mathrm{X}-1,140-150$ & 132.4 & 8.0 & - & - & 32.5 & 549 & 0.0 & 41.8 & 5.7 & 707.0 & 449.5 & 9.7 & 32.9 & 4.1 & 8.0 & 77.7 & 21.0 & 405.6 & 69.3 \\
\hline $18 X-2,126-156$ & 133.8 & 22.0 & 7.87 & 31.2 & 35.7 & 598 & 0.0 & 55.9 & 6.3 & 840.0 & 494.1 & 10.5 & 36.8 & 4.8 & 7.6 & 88.0 & 22.0 & 440.2 & 71.8 \\
\hline $19 X-3,21-30$ & 143.8 & 6.0 & - & - & 27.1 & 462 & 0.0 & 19.0 & 5.9 & - & - & - & - & - & - & - & - & - & - \\
\hline $19 X-3,21-30$ & 143.8 & 4.0 & - & - & 35.0 & 596 & 0.0 & - & 6.8 & - & - & - & - & - & - & - & - & - & - \\
\hline
\end{tabular}


Table T4 (continued).

\begin{tabular}{|c|c|c|c|c|c|c|c|c|c|c|c|c|c|c|c|c|c|c|c|}
\hline \multirow{2}{*}{$\begin{array}{l}\text { Core, section, } \\
\text { interval }(\mathrm{cm})\end{array}$} & \multirow{2}{*}{$\begin{array}{l}\text { Depth } \\
\text { (mbsf) }\end{array}$} & \multirow{2}{*}{$\begin{array}{l}\text { Volume } \\
(\mathrm{mL})\end{array}$} & \multirow[b]{2}{*}{$\mathrm{pH}$} & \multirow{2}{*}{$\begin{array}{l}\text { Alkalinity } \\
(\mathrm{mM})\end{array}$} & \multirow[b]{2}{*}{ Salinity } & \multirow{2}{*}{$\begin{array}{c}\mathrm{Cl} \\
(\mathrm{mM})\end{array}$} & \multirow{2}{*}{$\underset{(\mathrm{mM})}{\mathrm{SO}_{4}}$} & \multirow{2}{*}{$\begin{array}{l}\mathrm{PO}_{4} \\
(\mu \mathrm{M})\end{array}$} & \multirow{2}{*}{$\underset{(\mathrm{mM})}{\mathrm{NH}_{4}}$} & \multirow{2}{*}{$\begin{array}{c}\mathrm{H}_{4} \mathrm{SiO}_{4} \\
(\mu \mathrm{M})\end{array}$} & \multicolumn{4}{|c|}{ Cations (mM) } & \multirow[b]{2}{*}{$\mathrm{Mg} / \mathrm{Ca}$} & \multicolumn{4}{|c|}{ Trace elements $(\mu \mathrm{M})$} \\
\hline & & & & & & & & & & & $\mathrm{Na}$ & K & $\mathrm{Mg}$ & $\mathrm{Ca}$ & & $\mathrm{Sr}$ & $\mathrm{Li}$ & $B$ & $\mathrm{Ba}$ \\
\hline $19 X-5,31-53$ & 145.7 & 6.0 & - & - & 35.7 & 596 & 0.0 & 26.8 & 6.5 & 698.7 & 534.4 & 11.6 & 38.6 & 5.5 & 7.0 & 87.7 & 18.6 & 456.5 & 55.7 \\
\hline $20 X-3,45-64$ & 153.7 & 4.0 & - & - & 23.6 & 607 & 0.0 & 23.7 & 8.8 & - & 497.6 & 10.5 & 27.4 & 3.8 & 7.3 & - & - & - & - \\
\hline $20 X-3,45-64$ & 153.7 & 8.0 & - & - & 35.2 & 438 & 0.0 & - & 5.0 & - & - & - & - & - & - & - & - & - & - \\
\hline $20 X-5,120-150$ & 156.7 & 8.0 & - & - & 35.5 & 599 & 0.0 & 24.3 & 7.2 & 621.5 & 488.1 & 10.3 & 33.1 & 5.3 & 6.3 & 85.5 & 14.7 & 403.4 & 35.0 \\
\hline $21 X-1,37-51$ & 160.2 & 6.0 & - & - & 35.0 & 600 & 0.0 & 20.5 & 7.3 & - & - & - & - & - & - & - & - & - & - \\
\hline $21 \mathrm{X}-1,37-51$ & 160.2 & 4.0 & - & - & 17.5 & 310 & 0.0 & - & 4.8 & - & - & - & - & - & - & - & - & - & - \\
\hline $21 X-2,120-150$ & 161.7 & 7.0 & 7.89 & 23.5 & 35.5 & 605 & 0.0 & 15.4 & 6.9 & 554.7 & 496.0 & 10.2 & 33.2 & 5.7 & 5.8 & 87.6 & 14.0 & 351.4 & 32.4 \\
\hline $23 X-1,120-150$ & 171.8 & 18.0 & 7.74 & 22.5 & 35.5 & 603 & 0.0 & 20.1 & 7.2 & 646.4 & 490.9 & 9.4 & 32.4 & 6.0 & 5.4 & 86.9 & 11.9 & 384.4 & 25.8 \\
\hline $24 \mathrm{X}-2,0-11$ & 180.4 & 1.5 & - & - & 16.9 & 324 & 0.0 & - & 6.9 & 709.7 & 491.1 & 9.9 & 19.7 & 5.8 & 3.4 & 86.8 & 11.1 & 315.3 & 31.5 \\
\hline $24 \mathrm{X}-2,0-11$ & 180.4 & 2.0 & - & - & 34.0 & 592 & 0.0 & - & 8.7 & - & - & - & - & - & - & - & - & - & - \\
\hline $24 \mathrm{X}-3,120-150$ & 183.1 & 18.0 & 7.83 & 18.4 & 34.2 & 596 & 0.0 & 15.9 & 8.3 & 708.5 & 478.8 & 9.1 & 28.0 & 6.8 & 4.1 & 88.7 & 14.7 & 372.4 & 24.1 \\
\hline $24 X-4,0-14$ & 183.3 & 6.0 & - & - & 33.5 & 598 & 0.0 & 12.9 & 8.1 & 687.2 & 483.2 & 9.5 & 28.2 & 6.3 & 4.5 & 88.8 & 15.5 & 366.9 & 23.5 \\
\hline $24 X-4,0-14$ & 183.3 & 4.0 & - & - & 17.1 & 310 & 0.0 & - & 7.4 & - & - & - & - & - & - & - & - & - & - \\
\hline $24 X-5,112-145$ & 185.6 & 22.0 & 7.77 & 17.5 & 33.5 & 585 & 0.0 & 14.3 & 8.5 & 675.0 & 477.7 & 9.0 & 26.8 & 6.9 & 3.9 & 86.8 & 14.4 & 344.0 & 23.6 \\
\hline \multicolumn{20}{|l|}{ 311-U1325C- } \\
\hline $1 \mathrm{X}-1,120-150$ & 190.2 & 10.0 & 7.81 & 18.1 & 33.8 & 598.0 & 0.0 & 16.3 & 8.2 & 749.9 & 472.3 & 8.4 & 27.0 & 7.9 & 3.4 & 91.5 & 14.3 & 402.1 & 25.5 \\
\hline $1 X-2,141-151$ & 191.8 & 6.0 & - & - & 17.0 & 290.8 & 0.0 & 5.8 & 4.7 & 323.1 & 290.9 & 4.5 & 12.9 & 3.4 & 3.8 & 43.6 & 8.3 & 200.2 & 14.2 \\
\hline $1 X-2,141-151$ & 191.8 & 3.0 & - & - & 33.8 & 585.7 & 0.0 & - & 7.8 & - & - & - & - & - & - & - & - & - & - \\
\hline $2 X-1,0-43$ & 198.6 & 5.0 & - & - & 19.9 & 365.0 & 0.0 & 21.3 & 13.8 & 706.0 & 255.2 & 2.0 & 0.0 & 1.7 & 0.0 & 59.6 & 0.0 & 151.2 & 37.8 \\
\hline $2 X-1,0-43$ & 198.6 & 6.0 & - & - & 33.0 & 572.1 & 0.0 & - & 9.3 & 695.4 & 464.8 & 8.2 & 23.5 & 7.6 & 3.1 & 92.4 & 11.2 & 384.5 & 24.9 \\
\hline $4 \mathrm{X}-1,112-124$ & 209.2 & 11.0 & - & - & 15.0 & 263.0 & 0.0 & 3.3 & 5.8 & 261.5 & 212.8 & 3.3 & 6.2 & 2.6 & 2.4 & 31.6 & 4.9 & 119.5 & 12.3 \\
\hline $4 X-3,0-79$ & 210.5 & 12.0 & 8.06 & 14.4 & 32.3 & 565.1 & 0.0 & 5.4 & 9.7 & 536.7 & 460.8 & 8.6 & 23.1 & 7.6 & 3.1 & 86.7 & 8.6 & 339.8 & 25.0 \\
\hline$* 6 X-1,0-29$ & 218.7 & - & - & - & - & - & 0.0 & - & - & - & - & - & - & - & - & - & - & - & - \\
\hline $6 X-3,88-112$ & 221.4 & 2.0 & - & - & 13.2 & 286.1 & 0.0 & 6.1 & 11.8 & 565.3 & 457.4 & 8.3 & 17.2 & 6.9 & 2.5 & 81.5 & 3.9 & 178.1 & 29.9 \\
\hline $6 \mathrm{X}-3,88-112$ & 221.4 & 9.0 & 7.99 & 15.7 & 31.1 & 579.7 & 0.0 & 1.4 & 7.1 & - & - & - & - & - & - & - & - & - & - \\
\hline $7 X-2,0-50$ & 229.0 & 20.0 & 7.93 & 16.5 & 33.5 & 590.1 & 0.0 & 6.2 & 8.6 & 484.0 & 476.6 & 8.3 & 27.1 & 8.4 & 3.2 & 93.4 & 9.2 & 314.4 & 23.3 \\
\hline $7 X-4,69-79$ & 231.9 & 9.0 & - & - & 33.5 & 599.0 & 0.0 & 6.3 & 8.7 & 501.8 & 467.3 & 8.4 & 26.5 & 8.3 & 3.2 & 95.8 & 10.2 & 251.3 & 27.9 \\
\hline $7 X-4,69-79$ & 231.9 & 5.0 & - & - & 25.2 & 477.0 & 0.0 & 5.2 & 12.0 & - & - & - & - & - & - & - & - & - & - \\
\hline $8 X-2,62-85$ & 239.0 & 26.0 & 8.09 & 9.7 & 25.5 & 457.6 & 0.0 & - & 11.4 & 256.3 & 353.8 & 5.1 & 12.6 & 4.9 & 2.6 & 63.5 & 1.7 & 170.3 & 17.1 \\
\hline $8 X-4,0-50$ & 240.9 & 27.0 & 7.67 & 15.3 & 34.0 & 588.7 & 0.0 & - & 11.2 & 359.5 & 460.2 & 8.0 & 24.2 & 7.8 & 3.1 & 96.3 & 7.5 & 364.8 & 20.0 \\
\hline $9 \mathrm{X}-2,100-150$ & 249.3 & 40.0 & 7.86 & 15.1 & 33.8 & 585.5 & 0.0 & 6.2 & 12.7 & 463.3 & 467.0 & 7.5 & 24.5 & 8.5 & 2.9 & 104.9 & 5.7 & 417.2 & 18.6 \\
\hline $9 X-4,111-128$ & 252.2 & 10.0 & 8.0 & 15.2 & 33.7 & 599.2 & 0.0 & 6.9 & 13.1 & 252.7 & 476.9 & 8.7 & 22.9 & 7.8 & 2.9 & 102.2 & 6.1 & 319.8 & 21.9 \\
\hline $10 \mathrm{OP}-1,38519$ & 256.2 & 10.0 & - & - & 33.4 & 571.8 & 0.0 & - & - & - & - & - & - & - & - & - & - & - & - \\
\hline $10 \mathrm{P}-1,60-70$ & 256.8 & 35.0 & - & - & 34.5 & 603.9 & 0.0 & - & - & - & - & - & - & - & - & - & - & - & - \\
\hline $11 \mathrm{X}-2,105-150$ & 259.9 & 24.0 & 7.82 & 17.4 & 34.8 & 602.3 & 0.0 & - & 13.1 & 458.7 & 464.2 & 8.0 & 25.1 & 8.9 & 2.8 & 116.5 & 5.9 & 444.1 & 18.4 \\
\hline $11 X-5,0-45$ & 263.3 & 30.0 & 7.97 & 18.9 & 34.8 & 602.9 & 0.0 & 10.7 & 14.0 & 385.3 & 468.5 & 8.3 & 23.9 & 8.7 & 2.7 & 115.6 & 5.3 & 404.8 & 19.1 \\
\hline $12 X-3,0-45$ & 268.9 & 26.0 & 7.83 & 13.7 & 34.5 & 603.0 & 0.0 & - & 13.7 & 552.7 & 483.1 & 8.5 & 25.7 & 9.2 & 2.8 & 118.2 & 6.6 & 421.6 & 20.0 \\
\hline $14 \mathrm{X}-2,0-80$ & 286.3 & 12.0 & - & - & 35.0 & 603.8 & 0.0 & - & 14.3 & 525.4 & 471.2 & 9.1 & 23.2 & 8.4 & 2.8 & 110.6 & 10.1 & 430.4 & 27.1 \\
\hline $15 X-3,0-134$ & 297.8 & 21.0 & - & - & 34.7 & 602.3 & 0.0 & - & 16.1 & 500.8 & 478.2 & 9.6 & 24.2 & 8.5 & 2.8 & 112.4 & 17.4 & 417.6 & 28.0 \\
\hline $15 X-3,0-134$ & 297.8 & 8.0 & - & - & 34.7 & 601.7 & 0.0 & 7.9 & 15.6 & 555.4 & 477.3 & 9.5 & 23.6 & 8.3 & 2.9 & 113.8 & 18.1 & 423.6 & 28.7 \\
\hline $15 X-3,0-134$ & 297.8 & 6.0 & - & - & 35.0 & 601.0 & 0.0 & 5.4 & 16.2 & - & - & - & - & - & - & - & - & - & - \\
\hline 311-U1325D- & & & & & & & & & & & & & & & & & & & \\
\hline $1 \mathrm{H}-1,140-150$ & 1.4 & 60.0 & 7.58 & 13.4 & 34.2 & 554.5 & 19.6 & - & - & - & - & - & - & - & - & - & - & - & - \\
\hline $1 \mathrm{H}-2,140-151$ & 2.4 & 55.0 & 7.7 & 21.7 & 33.7 & 556.5 & 10.9 & - & - & - & - & - & - & - & - & - & - & - & - \\
\hline $1 \mathrm{H}-3,140-152$ & 4.3 & 40.0 & 7.81 & 29.5 & 33.5 & 555.5 & 2.1 & - & - & - & - & - & - & - & - & - & - & - & - \\
\hline $1 \mathrm{H}-3,140-153$ & 4.4 & 40.0 & 7.82 & 29.5 & 33.5 & 556.0 & 2.0 & - & - & - & - & - & - & - & - & - & - & - & - \\
\hline BW & - & - & - & - & 34.5 & 558.0 & 28.9 & - & - & 157.6 & 457.4 & 10.4 & 50.4 & 10.2 & 4.9 & - & - & - & - \\
\hline
\end{tabular}


Table T5. Hydrocarbon headspace gas concentrations, Holes U1325B, U1325C, and U1325D. (See table note. Continued on next page.)

\begin{tabular}{|c|c|c|c|c|c|c|c|}
\hline $\begin{array}{l}\text { Core, section, } \\
\text { interval }(\mathrm{cm})\end{array}$ & $\begin{array}{l}\text { Depth } \\
\text { (mbsf) }\end{array}$ & $\mathrm{C}_{1} / \mathrm{C}_{2}$ & $\begin{array}{c}\mathrm{C}_{1} \\
\text { (ppmv) }\end{array}$ & $\begin{array}{c}\mathrm{C}_{2} \\
(\mathrm{ppmv})\end{array}$ & $\begin{array}{c}C_{2=} \\
(p p m v)\end{array}$ & $\begin{array}{c}\mathrm{C}_{3} \\
(\mathrm{ppmv})\end{array}$ & $\begin{array}{c}\mathrm{C}_{1} \\
(\mathrm{mM})^{*}\end{array}$ \\
\hline \multicolumn{8}{|l|}{ 311-U1325B- } \\
\hline $1 \mathrm{H}-1,80-85$ & 0.80 & & 10 & 0 & 0 & 0 & 0.00 \\
\hline $1 \mathrm{H}-2,0-5$ & 1.50 & & 1,128 & 0 & 0 & 0 & 0.48 \\
\hline $1 \mathrm{H}-2,80-85$ & 2.30 & & 5,020 & 0 & 0 & 0 & 2.20 \\
\hline $1 \mathrm{H}-3,0-5$ & 3.00 & & 7,112 & 0 & 0 & 0 & 3.21 \\
\hline $1 \mathrm{H}-3,75-80$ & 3.75 & & 9,713 & 0 & 0 & 0 & 4.52 \\
\hline $1 \mathrm{H}-4,0-5$ & 4.50 & & 12,309 & 0 & 0 & 0 & 5.92 \\
\hline $1 \mathrm{H}-4,80-85$ & 5.30 & & 12,996 & 0 & 0 & 0 & 6.49 \\
\hline $1 \mathrm{H}-5,0-5$ & 6.00 & & 9,696 & 0 & 0 & 0 & 5.00 \\
\hline $1 \mathrm{H}-5,80-85$ & 6.80 & & 13,208 & 0 & 0 & 0 & 7.09 \\
\hline $1 \mathrm{H}-6,0-5$ & 7.50 & & 13,911 & 0 & 0 & 0 & 7.74 \\
\hline $1 \mathrm{H}-6,80-85$ & 8.30 & & 3,659 & 0 & 0 & 0 & 2.12 \\
\hline $1 \mathrm{H}-7,0-5$ & 9.00 & & 2,748 & 0 & 0 & 0 & 1.66 \\
\hline $2 \mathrm{H}-3,0-5$ & 12.30 & & 10,931 & 0 & 0 & 0 & 7.41 \\
\hline $2 \mathrm{H}-7,0-5$ & 18.30 & & 7,504 & 0 & 0 & 0 & 5.02 \\
\hline $3 X-1,145-150$ & 20.25 & & 3,733 & 0 & 0 & 0 & 2.48 \\
\hline $4 \mathrm{H}-3,0-5$ & 26.82 & & 5,915 & 0 & 0 & 0 & 3.88 \\
\hline $4 \mathrm{H}-6,0-5$ & 31.32 & & 7,722 & 0 & 0 & 0 & 5.01 \\
\hline $5 \mathrm{H}-3,0-5$ & 36.42 & & 4,051 & 0 & 0 & 0 & 2.60 \\
\hline $5 \mathrm{H}-6,0-5$ & 40.92 & & 4,491 & 0 & 0 & 0 & 2.85 \\
\hline $6 \mathrm{H}-3,0-5$ & 46.00 & & 7,252 & 0 & 0 & 0 & 4.56 \\
\hline $6 \mathrm{H}-6,0-5$ & 50.50 & & 4,834 & 0 & 0 & 0 & 3.01 \\
\hline $7 \mathrm{H}-4,0-5$ & 57.00 & & 4,589 & 0 & 0 & 0 & 2.82 \\
\hline $7 \mathrm{H}-6,0-5$ & 60.00 & & 4,500 & 0 & 0 & 0 & 2.75 \\
\hline $8 \mathrm{H}-4,0-5$ & 66.26 & & 4,651 & 0 & 0 & 0 & 2.80 \\
\hline $8 \mathrm{H}-6,0-5$ & 69.26 & & 3,401 & 0 & 0 & 0 & 2.04 \\
\hline $9 X-1,137-142$ & 72.87 & & 2,267 & 0 & 0 & 0 & 1.21 \\
\hline $10 X-4,0-5$ & 77.30 & & 2,817 & 0 & 0 & 0 & 1.39 \\
\hline $10 X-5,117-121$ & 79.97 & & 2,755 & 0 & 0 & 0 & 1.44 \\
\hline $12 X-3,0-5$ & 87.40 & & 3,785 & 0 & 0 & 0 & 2.38 \\
\hline $12 X-4,63-68$ & 89.53 & & 2,172 & 0 & 0 & 0 & 1.45 \\
\hline $13 X-C C, 10-15$ & 93.53 & & 3,459 & 0 & 0 & 0 & 2.60 \\
\hline $14 X-3,0-5$ & 105.30 & & 3,730 & 0 & 0 & 0 & 2.01 \\
\hline $14 X-6,25-30$ & 109.88 & & 2,794 & 0 & 0 & 0 & 1.70 \\
\hline $15 X-2,120-125$ & 114.40 & & 3,119 & 0 & 0 & 0 & 2.17 \\
\hline $15 X-3,14-19$ & 114.84 & & 3,685 & 0 & 0 & 0 & 2.60 \\
\hline $16 X-3,0-5$ & 124.30 & & 4,755 & 0 & 0 & 0 & 2.88 \\
\hline $16 \times-5,0-5$ & 126.15 & & 3,165 & 0 & 0 & 0 & 1.80 \\
\hline $16 X-7,0-5$ & 128.15 & & 3,593 & 0 & 0 & 0 & 1.92 \\
\hline $18 X-2,0-5$ & 132.40 & & 3,539 & 0 & 0 & 0 & 1.91 \\
\hline $18 X-2,121-126$ & 133.61 & & 2,086 & 0 & 0 & 0 & 1.13 \\
\hline $19 X-3,16-21$ & 143.66 & & 2,122 & 0 & 0 & 0 & 1.18 \\
\hline $19 X-5,0-5$ & 145.30 & & 2,027 & 0 & 0 & 0 & 1.14 \\
\hline $20 X-3,40-45$ & 153.60 & & 2,081 & 0 & 0 & 0 & 1.19 \\
\hline $20 X-6,0-5$ & 156.84 & & 4,007 & 0 & 0 & 0 & 2.32 \\
\hline $21 X-1,32-37$ & 160.12 & & 2,379 & 0 & 0 & 0 & 1.39 \\
\hline $21 X-3,0-5$ & 161.81 & & 1,094 & 0 & 0 & 0 & 0.64 \\
\hline $23 X-2,0-5$ & 171.90 & & 1,850 & 0 & 0 & 0 & 1.12 \\
\hline $24 X-2,0-5$ & 180.39 & & 1,966 & 0 & 0 & 0 & 1.23 \\
\hline $24 X-3,0-5$ & 181.77 & & 2,335 & 0 & 0 & 0 & 1.46 \\
\hline \multicolumn{8}{|l|}{ 311-U1325C- } \\
\hline $1 X-2,0-5$ & 190.30 & & 3,119 & 0 & 0 & 0 & 2.01 \\
\hline $1 X-2,136-141$ & 191.66 & & 3,683 & 0 & 0 & 0 & 2.38 \\
\hline $2 X-1,5-7$ & 198.45 & & 25,679 & 0 & 0 & 0 & 17.01 \\
\hline $2 X-1,8-10$ & 198.48 & & 2,285 & 0 & 0 & 0 & 1.51 \\
\hline $4 X-2,0-5$ & 209.24 & & 4,166 & 0 & 0 & 0 & 2.82 \\
\hline $4 X-4,0-5$ & 210.92 & & 3,244 & 0 & 0 & 0 & 2.19 \\
\hline $6 X-2,0-5$ & 218.89 & & 5,283 & 0 & 0 & 0 & 3.52 \\
\hline $7 X-2,50-55$ & 229.20 & & 4,172 & 0 & 0 & 0 & 2.74 \\
\hline $7 X-4,64-69$ & 231.84 & & 4,040 & 0 & 0 & 0 & 2.65 \\
\hline $8 X-2,72-75$ & 239.02 & & 11,017 & 0 & 0 & 0 & 7.15 \\
\hline $8 X-3,0-5$ & 239.15 & & 2,785 & 0 & 0 & 0 & 1.81 \\
\hline $8 X-4,50-55$ & 241.15 & & 5,061 & 0 & 0 & 0 & 3.27 \\
\hline $9 X-2,95-100$ & 248.95 & 5,898 & 3,539 & 0.6 & 0 & 0 & 2.26 \\
\hline $9 X-4,106-111$ & 252.06 & 8,020 & 5,614 & 0.7 & 0 & 0 & 3.58 \\
\hline $9 X-4,120-123$ & 252.20 & & 4,775 & 0 & 0 & 0 & 3.04 \\
\hline $11 X-2,100-105$ & 259.60 & & 2,063 & 0 & 0 & 0 & 1.30 \\
\hline
\end{tabular}


Table T5 (continued).

\begin{tabular}{lccccccc}
\hline $\begin{array}{c}\text { Core, section, } \\
\text { interval (cm) }\end{array}$ & $\begin{array}{c}\text { Depth } \\
\text { (mbsf) }\end{array}$ & $\mathrm{C}_{1} / \mathrm{C}_{2}$ & $\begin{array}{c}\mathrm{C}_{1} \\
(\mathrm{ppmv})\end{array}$ & $\begin{array}{c}\mathrm{C}_{2} \\
(\mathrm{ppmv})\end{array}$ & $\begin{array}{c}\mathrm{C}_{2=} \\
(\mathrm{ppm})\end{array}$ & $\begin{array}{c}\mathrm{C}_{3} \\
(\mathrm{ppmv})\end{array}$ & $\begin{array}{c}\mathrm{C}_{1} \\
(\mathrm{mM})^{*}\end{array}$ \\
\hline $11 \mathrm{X}-5,45-50$ & 263.55 & & 2,801 & 0 & 0 & 0 & 1.76 \\
$12 \mathrm{X}-1,145-150$ & 267.25 & & 3,671 & 0 & 0 & 0 & 2.29 \\
$14 \mathrm{X}-3,0-5$ & 286.70 & 6,350 & 2,540 & 0.4 & 0 & 0 & 1.54 \\
$15 \mathrm{X}-2,90-95$ & 297.04 & & 2,901 & 0 & 0 & 0 & 1.74 \\
$15 \mathrm{X}-4,0-5$ & 298.43 & 4,277 & 3,849 & 0.9 & 0 & 0 & 2.31 \\
$311-\mathrm{U} 1325 \mathrm{D}-$ & & & & & & & \\
$1 \mathrm{H}-1,135-140$ & 1.35 & & 4.0 & 0 & 0 & 0 & 0.00 \\
$1 \mathrm{H}-2,135-140$ & 2.85 & & 5.0 & 0 & 0 & 0 & 0.00 \\
$1 \mathrm{H}-3,125-130$ & 4.25 & & 16.6 & 0 & 0 & 0 & 0.01 \\
\hline
\end{tabular}

Note: * $=$ dissolved residual methane obtained by the headspace equilibration method. 
Table T6. Concentrations of light hydrocarbon and nonhydrocarbon gases in core gas void samples, Holes U1325B and U1325C.

\begin{tabular}{|c|c|c|c|c|c|c|c|c|c|c|c|c|c|}
\hline \multirow{2}{*}{$\begin{array}{l}\text { Core, section, } \\
\text { interval }(\mathrm{cm})\end{array}$} & \multirow{2}{*}{$\begin{array}{l}\text { Depth } \\
\text { (mbsf) }\end{array}$} & \multicolumn{8}{|c|}{ Hydrocarbons (ppmv) } & \multicolumn{4}{|c|}{ Volatiles (ppmv) } \\
\hline & & $\mathrm{C}_{1} / \mathrm{C}_{2}$ & $\mathrm{C}_{1}$ & $\mathrm{C}_{2}$ & $\mathrm{C}_{3}$ & $i-\mathrm{C}_{4}$ & $n-C_{4}$ & $i-\mathrm{C}_{5}$ & $n-C_{5}$ & $\mathrm{H}_{2} \mathrm{~S}$ & $\mathrm{CO}_{2}$ & $\mathrm{O}_{2}$ & $\mathrm{~N}_{2}$ \\
\hline \multicolumn{14}{|l|}{ 311-U1325B- } \\
\hline $1 \mathrm{H}-7,6-7$ & 9.06 & 138,248 & 594,467 & 4.3 & 0.0 & 0.0 & 0.0 & 0.0 & 0.0 & 0.0 & 11,883 & 66,140 & 285,165 \\
\hline $2 \mathrm{H}-4,80-81$ & 14.60 & 144,286 & 894,573 & 6.2 & 0.0 & 0.0 & 0.0 & 0.0 & 0.0 & 0.0 & 11,268 & 1,235 & 25,122 \\
\hline $2 \mathrm{H}-6,137-138$ & 18.17 & 61,355 & 85,897 & 1.4 & 0.0 & 0.0 & 0.0 & 0.0 & 5.1 & 0.0 & 1,382 & NA & NA \\
\hline $4 \mathrm{H}-2,12-13$ & 25.44 & 153,353 & 904,780 & 5.9 & 0.0 & 0.0 & 0.0 & 0.0 & 0.0 & 0.0 & 8,594 & 4,073 & 30,123 \\
\hline $4 \mathrm{H}-2,2-3$ & 28.34 & 148,899 & 908,284 & 6.1 & 0.0 & 0.3 & 0.0 & 0.0 & 0.0 & 0.0 & 4,350 & 1,260 & 31,118 \\
\hline $5 \mathrm{H}-2,19-20$ & 35.19 & 145,346 & 915,680 & 6.3 & 0.0 & 0.4 & 0.0 & 0.0 & 0.0 & 0.0 & 5,551 & 1,269 & 18,689 \\
\hline $6 \mathrm{H}-1,125-126$ & 44.25 & & 973,108 & NA & 0.0 & 0.3 & 0.0 & 0.0 & 0.0 & 0.0 & 3,892 & 2,112 & 15,372 \\
\hline $6 \mathrm{H}-6,102-103$ & 51.52 & 145,962 & 919,561 & 6.3 & 0.0 & 0.3 & 0.0 & 0.0 & 0.0 & 0.0 & 6,236 & 1,172 & 11,841 \\
\hline $7 \mathrm{H}-2,52-53$ & 54.52 & 171,321 & 873,736 & 5.1 & 0.0 & 0.0 & 0.0 & 0.0 & 0.0 & 0.0 & 4,806 & 3,769 & 20,908 \\
\hline $7 \mathrm{H}-7,13-14$ & 61.39 & & 969,969 & NA & 0.0 & 0.0 & 0.0 & 0.0 & 0.0 & 0.0 & 4,563 & 1,272 & 15,114 \\
\hline $8 \mathrm{H}-2,7-8$ & 63.33 & 173,774 & 921,000 & 5.3 & 0.0 & 0.0 & 0.0 & 0.4 & 0.0 & 0.0 & 4,610 & 1,225 & 10,870 \\
\hline $8 \mathrm{H}-7,23-24$ & 70.49 & & 972,800 & NA & 0.0 & 0.0 & 0.0 & 0.0 & 0.0 & 0.0 & 4,886 & 1,169 & 8,644 \\
\hline $10 \times-2,56-57$ & 74.86 & 156,812 & 909,508 & 5.8 & 0.0 & 0.4 & 0.0 & 0.0 & 0.7 & 0.0 & 8,174 & 1,599 & $11,11 \varepsilon$ \\
\hline $10 X-6,69-70$ & 80.79 & 140,878 & 788,920 & 5.6 & 1.6 & 0.5 & 0.0 & 0.0 & 0.6 & 0.0 & 8,173 & 30,434 & 118,602 \\
\hline $12 X-1,91-92$ & 85.31 & 156,736 & 909,068 & 5.8 & 0.6 & 1.5 & 0.0 & 0.0 & 0.0 & 0.0 & 5,473 & 2,541 & 15,067 \\
\hline $12 X-3,142-143$ & 88.82 & 167,026 & 718,212 & 4.3 & 0.0 & 1.9 & 0.0 & 0.5 & 0.4 & 0.0 & 5,141 & 46,691 & 184,946 \\
\hline $14 X-2,62-63$ & 104.42 & 128,845 & 193,268 & 1.5 & 0.0 & 0.0 & 0.0 & 0.0 & 0.5 & 0.0 & 2,131 & NA & NA \\
\hline $14 X-5,129-130$ & 109.59 & 97,603 & 683,224 & 7.0 & 0.0 & 0.0 & 0.0 & 0.4 & 0.3 & 0.0 & 4,572 & 53,836 & 213,615 \\
\hline $15 X-3,11-12$ & 114.81 & 83,096 & 830,963 & 10.0 & 2.7 & 0.7 & 0.4 & 0.0 & 0.5 & 0.0 & 4,735 & 20,867 & 83,761 \\
\hline $16 X-2,20-21$ & 123.00 & 107,888 & 917,048 & 8.5 & 3.3 & 0.6 & 0.0 & 0.0 & 0.7 & 0.0 & 6,394 & 858 & 6,532 \\
\hline $16 \mathrm{X}-3,147-148$ & 125.77 & 83,368 & 908,715 & 10.9 & 0.0 & 0.6 & 0.3 & 0.0 & 0.6 & 0.0 & 6,295 & 2,499 & 12,607 \\
\hline $16 \mathrm{X}-6,131-132$ & 127.96 & 115,104 & 828,752 & 7.2 & 0.0 & 0.6 & 0.4 & 0.0 & 1.0 & 0.0 & 6,931 & 21,808 & 83,745 \\
\hline $18 X-1,55-56$ & 131.45 & 116,978 & 912,426 & 7.8 & 2.8 & 0.3 & 0.0 & 0.0 & 0.5 & 0.0 & 2,831 & 2,659 & 16,089 \\
\hline $19 X-4,145-146$ & 145.25 & 88,650 & 877,638 & 9.9 & 5.1 & 0.0 & 0.0 & 0.0 & 0.0 & 0.0 & 3,825 & 2,048 & 11,762 \\
\hline $20 X-6,77-78$ & 157.61 & 104,984 & 304,455 & 2.9 & 0.0 & 0.3 & 0.0 & 0.0 & 0.0 & 0.0 & 1,722 & 139,444 & 508,952 \\
\hline $21 X-2,1-2$ & 160.32 & 80,719 & 904,049 & 11.2 & 0.0 & 0.2 & 1.2 & 0.0 & 0.0 & 0.0 & 1,769 & 6,010 & 26,091 \\
\hline $24 X-1,90-91$ & 179.90 & 62,001 & 886,608 & 14.3 & 0.0 & 0.4 & 0.0 & 0.0 & 0.0 & 0.0 & 2,393 & 10,637 & 42,325 \\
\hline $24 X-3,95-96$ & 182.72 & 71,801 & 926,231 & 12.9 & 2.4 & 0.4 & 0.0 & 0.0 & 0.0 & 0.0 & 3,404 & 2,001 & 10,023 \\
\hline \multicolumn{14}{|l|}{ 311-U1325C- } \\
\hline $1 X-2,37-38$ & 190.67 & 104,873 & 786,547 & 7.5 & 0.0 & 0.2 & 3.9 & 0.0 & 0.0 & 0.0 & 3,152 & 32,584 & 126,982 \\
\hline $4 X-1,38-39$ & 208.38 & 95,451 & 925,872 & 9.7 & 0.0 & 1.0 & 1.2 & 1.0 & 0.7 & 0.0 & 1,766 & 27,941 & 109,450 \\
\hline $4 X-3,16-17$ & 210.29 & 205,253 & 903,113 & 4.4 & 0.0 & 1.2 & 1.3 & 1.1 & 0.7 & 0.0 & 1,727 & 23,271 & 98,092 \\
\hline $6 X-2,126-127$ & 220.15 & 85,094 & 919,020 & 10.8 & 0.0 & 0.2 & 4.6 & 0.0 & 0.0 & 0.0 & 1,414 & 1,213 & 18,500 \\
\hline $6 \mathrm{X}-4,17-18$ & 221.68 & 82,812 & 927,498 & 11.2 & 0.0 & 0.8 & 0.0 & 0.0 & 0.0 & 0.0 & 704 & 711 & 4,798 \\
\hline $7 X-2,140-141$ & 230.10 & 97,074 & 931,914 & 9.6 & 0.0 & 37.8 & 0.0 & 0.0 & 0.0 & 0.0 & 607 & 685 & 4,642 \\
\hline $7 X-6,116-117$ & 233.83 & 50,496 & 934,171 & 18.5 & 0.0 & 0.0 & 0.0 & 0.0 & 0.0 & 0.0 & 342 & 698 & 3,198 \\
\hline $8 X-2,55-56$ & 238.85 & 61,768 & 932,694 & 15.1 & 0.0 & 1.1 & 0.0 & 0.0 & 0.0 & 0.0 & 1,249 & 522 & 4,096 \\
\hline $8 X-6,55-56$ & 243.85 & 67,755 & 935,015 & 13.8 & 0.0 & 0.3 & 0.3 & 0.0 & 0.7 & 0.0 & 578 & 676 & 5,770 \\
\hline $9 \mathrm{X}-1,124-125$ & 247.74 & 19,251 & 912,508 & 47.4 & 0.0 & 0.2 & 0.0 & 0.0 & 0.0 & 0.0 & 1,588 & 2,855 & 15,469 \\
\hline $9 X-5,94-95$ & 253.22 & 17,163 & 933,692 & 54.4 & 0.0 & 0.2 & 0.0 & 0.0 & 0.0 & 0.0 & 3,822 & 490 & 3,530 \\
\hline $11 X-3,57-58$ & 260.67 & 13,636 & 923,174 & 67.7 & 0.0 & 6.0 & 0.0 & 0.0 & 0.0 & 0.0 & 955 & 1,229 & 8,173 \\
\hline $12 X-2,128-129$ & 268.58 & 10,978 & 902,424 & 82.2 & 0.0 & 0.3 & 0.0 & 0.0 & 0.0 & 0.0 & 2,691 & 5,281 & 24,129 \\
\hline $14 X-3,1-2$ & 286.71 & 9,382 & 757,126 & 80.7 & 10.1 & 0.2 & 1.6 & 0.0 & 0.0 & 0.0 & 3,186 & 33,451 & 133,815 \\
\hline $15 X-2,75-76$ & 296.89 & 9,665 & 918,163 & 95.0 & 14.8 & 0.8 & 1.1 & 0.0 & 0.0 & 0.0 & 4,358 & 1,703 & 12,515 \\
\hline $15 X-3,75-76$ & 297.84 & 10,560 & 927,172 & 87.8 & 12.4 & 0.5 & 0.6 & 0.0 & 0.0 & 0.0 & 2,125 & 905 & 5,516 \\
\hline
\end{tabular}

Note: NA = not analyzed. 
Table T7. Contents of inorganic carbon, $\mathrm{CaCO}_{3}$ organic carbon, total organic carbon, and total nitrogen, Holes U1325B and U1325C.

\begin{tabular}{|c|c|c|c|c|c|c|c|}
\hline \multirow{2}{*}{$\begin{array}{l}\text { Core, section, } \\
\text { interval }(\mathrm{cm})\end{array}$} & \multirow{2}{*}{$\begin{array}{l}\text { Depth } \\
\text { (mbsf) }\end{array}$} & \multicolumn{4}{|c|}{ Carbon (wt\%) } & \multirow{2}{*}{$\begin{array}{c}\text { Total } \\
\text { nitrogen } \\
(w t \%)\end{array}$} & \multirow[b]{2}{*}{$\mathrm{C} / \mathrm{N}$} \\
\hline & & Carbonate & $\mathrm{CaCO}_{3}$ & Total & Organic & & \\
\hline \multicolumn{8}{|l|}{ 311-U1325B- } \\
\hline $1 \mathrm{H}-1,65-80$ & 0.65 & 0.25 & 2.06 & 1.966 & 1.72 & 0.22 & 7.8 \\
\hline $1 \mathrm{H}-1,135-150$ & 1.35 & 0.5 & 4.18 & 0.95 & 0.45 & 0.072 & 6.3 \\
\hline $1 \mathrm{H}-2,65-80$ & 2.15 & 0.39 & 3.23 & 1.831 & 1.44 & 0.175 & 8.2 \\
\hline $1 \mathrm{H}-2,135-150$ & 2.85 & 0.46 & 3.81 & 0.919 & 0.46 & 0.045 & 10.2 \\
\hline $1 \mathrm{H}-3,60-75$ & 3.60 & 0.25 & 2.05 & 0.446 & 0.2 & 0.017 & 11.8 \\
\hline $1 \mathrm{H}-3,135-150$ & 4.35 & 0.31 & 2.54 & 0.568 & 0.26 & 0.028 & 9.3 \\
\hline $1 \mathrm{H}-4,65-80$ & 5.15 & 0.35 & 2.88 & 1.09 & 0.74 & 0.093 & 8.0 \\
\hline $1 \mathrm{H}-4,135-150$ & 5.85 & 0.34 & 2.86 & 1.95 & 1.61 & 0.188 & 8.6 \\
\hline $1 \mathrm{H}-5,65-80$ & 6.65 & 0.37 & 3.04 & 1.025 & 0.65 & 0.079 & 8.2 \\
\hline $1 \mathrm{H}-5,135-150$ & 7.35 & 0.42 & 3.53 & 1.199 & 0.78 & 0.102 & 7.6 \\
\hline $1 \mathrm{H}-6,65-80$ & 8.15 & 0.37 & 3.05 & 0.539 & 0.17 & 0.029 & 5.9 \\
\hline $1 \mathrm{H}-6,135-150$ & 8.85 & 0.41 & 3.42 & 0.899 & 0.49 & 0.06 & 8.2 \\
\hline $2 \mathrm{H}-2,135-150$ & 12.15 & 0.16 & 1.32 & 0.183 & 0.02 & 0.048 & 0.4 \\
\hline $2 \mathrm{H}-6,135-150$ & 18.15 & 0.27 & 2.24 & 0.797 & 0.53 & 0.058 & 9.1 \\
\hline $4 \mathrm{H}-5,135-150$ & 31.17 & 0.72 & 5.98 & 1.95 & 1.23 & 0.156 & 7.9 \\
\hline $5 \mathrm{H}-5,135-150$ & 40.77 & 0.2 & 1.67 & 1.54 & 1.34 & 0.151 & 8.9 \\
\hline $6 \mathrm{H}-2,135-150$ & 45.85 & 0.53 & 4.43 & 1.07 & 0.54 & 0.074 & 7.3 \\
\hline $6 \mathrm{H}-5,135-150$ & 50.35 & 0.47 & 3.92 & 1.075 & 0.6 & 0.08 & 7.5 \\
\hline 7H-5, 135-150 & 59.85 & 0.35 & 2.95 & 0.708 & 0.36 & 0.035 & 10.3 \\
\hline $8 \mathrm{H}-5,123-150$ & 68.99 & 0.1 & 0.80 & 0.434 & 0.33 & 0.04 & 8.3 \\
\hline $9 X-2,0-25$ & 72.92 & 0.09 & 0.78 & 0.554 & 0.46 & 0.052 & 8.8 \\
\hline $10 X-3,125-150$ & 77.05 & 0.34 & 2.82 & 1.242 & 0.9 & 0.12 & 7.5 \\
\hline $12 X-2,125-150$ & 87.15 & 0.2 & 1.71 & 0.629 & 0.43 & 0.053 & 8.1 \\
\hline $14 X-2,125-150$ & 105.05 & 0.91 & 7.59 & 1.602 & 0.69 & 0.104 & 6.6 \\
\hline $15 X-2,120-150$ & 114.40 & 0.08 & 0.68 & 0.55 & 0.47 & 0.05 & 9.4 \\
\hline $16 X-2,120-150$ & 124.00 & 0.16 & 1.32 & 0.646 & 0.49 & 0.079 & 6.2 \\
\hline $16 X-4,25-35$ & 126.05 & 0.41 & 3.39 & 0.784 & 0.37 & 0.05 & 7.4 \\
\hline $16 X-6,120-150$ & 127.85 & 1.36 & 11.36 & 1.92 & 0.56 & 0.071 & 7.9 \\
\hline $18 X-2,126-156$ & 133.66 & 1.04 & 8.67 & 1.87 & 0.83 & 0.114 & 7.3 \\
\hline $19 X-3,21-30$ & 143.71 & 1.1 & 9.13 & 1.55 & 0.45 & 0.058 & 7.8 \\
\hline $20 X-3,45-64$ & 153.65 & 0.4 & 3.37 & 0.855 & 0.45 & 0.073 & 6.2 \\
\hline $23 X-1,120-150$ & 171.60 & 0.38 & 3.19 & 0.832 & 0.45 & 0.065 & 6.9 \\
\hline $24 X-4,0-14$ & 183.27 & 0.85 & 7.08 & 1.48 & 0.63 & 0.107 & 5.9 \\
\hline \multicolumn{8}{|l|}{ 311-U1325C- } \\
\hline $1 X-1,125-150$ & 190.05 & 0.29 & 2.44 & 0.606 & 0.32 & 0.056 & 5.7 \\
\hline $2 X-1,0-43$ & 198.40 & 0.46 & 3.86 & 0.666 & 0.21 & 0.072 & 2.9 \\
\hline $4 X-1,112-124$ & 209.12 & 0.16 & 1.3 & 0.15 & 0.00 & 0.019 & \\
\hline $6 X-3,88-112$ & 221.27 & 0.19 & 1.61 & 0.404 & 0.21 & 0.037 & 5.7 \\
\hline $7 X-2,0-50$ & 228.70 & 0.25 & 2.07 & 0.533 & 0.28 & 0.05 & 5.6 \\
\hline $8 X-2,62-85$ & 238.92 & 0.18 & 1.5 & 0.349 & 0.17 & 0.036 & 4.7 \\
\hline $9 X-2,100-150$ & 249.00 & 0.23 & 1.91 & 0.621 & 0.39 & 0.069 & 5.7 \\
\hline $11 X-2,105-150$ & 259.65 & 0.28 & 2.34 & 0.589 & 0.31 & 0.068 & 4.6 \\
\hline $12 X-3,0-45$ & 268.67 & 0.18 & 1.49 & 0.5 & 0.32 & 0.063 & 5.1 \\
\hline $14 X-2,0-80$ & 285.90 & 0.17 & 1.41 & 0.459 & 0.29 & 0.05 & 5.8 \\
\hline $15 X-3,0-134$ & 297.09 & 0.14 & 1.12 & 0.498 & 0.36 & 0.056 & 6.4 \\
\hline
\end{tabular}


Table T8. Perfluorocarbon tracer and fluorescent microsphere concentrations, Site U1325.

\begin{tabular}{|c|c|c|c|c|c|c|}
\hline \multirow{2}{*}{$\begin{array}{l}\text { Core, section, } \\
\text { interval }(\mathrm{cm})\end{array}$} & \multirow{2}{*}{$\begin{array}{l}\text { Depth } \\
\text { (mbsf) }\end{array}$} & \multicolumn{2}{|c|}{$\begin{array}{c}\text { Detected PFT } \\
\text { (ng/g sediment) }\end{array}$} & \multicolumn{2}{|c|}{$\begin{array}{c}\text { Detected particles } \\
\text { (number/g sediment) }\end{array}$} & \multirow[b]{2}{*}{ Comments } \\
\hline & & Inner & Outer & Inner & Outer & \\
\hline \multicolumn{7}{|l|}{ APC cores } \\
\hline \multicolumn{7}{|l|}{ 311-U1325B- } \\
\hline $1 \mathrm{H}-3,5-10$ & 3.05 & $\mathrm{BDL}$ & 0.0247 & BDL & $4.0 \times 10^{4}$ & \\
\hline $4 \mathrm{H}-5,5-10$ & 29.87 & $\mathrm{BDL}$ & $\mathrm{BDL}$ & BDL & $\mathrm{BDL}$ & \\
\hline $7 \mathrm{H}-4,0-5$ & 57.00 & $\mathrm{BDL}$ & 0.0053 & BDL & $>0.1 \times 10^{4}$ & \\
\hline \multicolumn{7}{|l|}{ XCB cores } \\
\hline \multicolumn{7}{|l|}{ 311-U1325B- } \\
\hline $24 \mathrm{X}-2,60-61$ & 180.99 & ND & ND & BDL & $0.6 \times 10^{4}$ & Biscuit \\
\hline $24 X-2,63-64$ & 181.02 & ND & ND & $>0.1 \times 10^{4}$ & $0.2 \times 10^{4}$ & Nonbiscuit \\
\hline \multicolumn{7}{|l|}{ 311-U1325C- } \\
\hline $8 X-2,37-38$ & 238.67 & ND & ND & $\mathrm{BDL}$ & $>0.1 \times 10^{4}$ & Nonbiscuit \\
\hline $8 X-2,42-43$ & 238.72 & ND & ND & $\mathrm{BDL}$ & $\mathrm{BDL}$ & Biscuit \\
\hline
\end{tabular}

Notes: $\mathrm{APC}=$ advanced piston corer $\mathrm{XCB}=$ extended core barrel. $\mathrm{PFT}=$ perfluorocarbon tracers. $\mathrm{BDL}=$ below detection limit, $\mathrm{ND}=$ no data. 
Table T9. Moisture and density, Holes U1325B, U1325C, and U1325D. (Continued on next page.)

\begin{tabular}{|c|c|c|c|c|}
\hline \multirow{2}{*}{$\begin{array}{l}\text { Core, section, } \\
\text { interval }(\mathrm{cm})\end{array}$} & \multirow{2}{*}{$\begin{array}{l}\text { Depth } \\
\text { (mbsf) }\end{array}$} & \multicolumn{2}{|c|}{ Density $\left(\mathrm{g} / \mathrm{cm}^{3}\right)$} & \multirow{2}{*}{$\begin{array}{c}\text { Porosity } \\
\text { (\%) }\end{array}$} \\
\hline & & Bulk & Grain & \\
\hline \multicolumn{5}{|l|}{ 311-U1325B- } \\
\hline $1 \mathrm{H}-2,7-9$ & 1.57 & 1.513 & 2.689 & 70.6 \\
\hline $1 \mathrm{H}-2,36-38$ & 1.86 & 1.491 & 2.694 & 72.0 \\
\hline $1 \mathrm{H}-2,54-56$ & 2.04 & 1.446 & 2.736 & 75.4 \\
\hline $1 \mathrm{H}-4,8-10$ & 4.58 & 1.846 & 2.774 & 53.0 \\
\hline $1 \mathrm{H}-4,39-41$ & 4.89 & 1.639 & 2.705 & 63.4 \\
\hline $1 \mathrm{H}-5,18-20$ & 6.18 & 1.771 & 2.732 & 56.3 \\
\hline $1 \mathrm{H}-5,52-54$ & 6.52 & 1.686 & 2.711 & 60.7 \\
\hline $1 \mathrm{H}-6,23-25$ & 7.73 & 1.981 & 2.739 & 44.2 \\
\hline $1 \mathrm{H}-6,46-48$ & 7.96 & 1.975 & 2.737 & 44.5 \\
\hline $1 \mathrm{H}-6,61-63$ & 8.11 & 1.881 & 2.765 & 50.8 \\
\hline $1 \mathrm{H}-7,7-9$ & 9.07 & 2.063 & 2.754 & 40.0 \\
\hline $1 \mathrm{H}-7,29-31$ & 9.29 & 2.050 & 2.761 & 40.9 \\
\hline $2 \mathrm{H}-1,19-21$ & 9.49 & 2.033 & 2.767 & 42.1 \\
\hline $2 \mathrm{H}-1,98-100$ & 10.28 & 2.073 & 2.776 & 40.1 \\
\hline $2 \mathrm{H}-2,17-19$ & 10.97 & 1.865 & 2.759 & 51.5 \\
\hline $2 \mathrm{H}-2,106-108$ & 11.86 & 1.804 & 2.758 & 55.0 \\
\hline $2 \mathrm{H}-3,64-66$ & 12.94 & 2.021 & 2.750 & 42.2 \\
\hline $2 \mathrm{H}-4,23-25$ & 14.03 & 2.067 & 2.789 & 40.9 \\
\hline $2 \mathrm{H}-4,73-75$ & 14.53 & 2.048 & 2.751 & 40.7 \\
\hline $2 \mathrm{H}-4,117-119$ & 14.97 & 1.919 & 2.744 & 48.0 \\
\hline $2 \mathrm{H}-5,9-11$ & 15.39 & 1.840 & 2.712 & 51.7 \\
\hline $2 \mathrm{H}-5,79-81$ & 16.09 & 1.924 & 2.720 & 46.9 \\
\hline $2 \mathrm{H}-5,105-107$ & 16.35 & 1.937 & 2.734 & 46.6 \\
\hline $2 \mathrm{H}-5,144-146$ & 16.74 & 1.779 & 2.727 & 55.7 \\
\hline $2 \mathrm{H}-7,6-8$ & 18.36 & 1.760 & 2.712 & 56.4 \\
\hline $2 \mathrm{H}-7,66-68$ & 18.96 & 1.806 & 2.760 & 55.0 \\
\hline $3 X-1,66-68$ & 19.46 & 1.966 & 2.731 & 44.8 \\
\hline $3 X-1,69-71$ & 19.49 & 2.096 & 2.729 & 37.2 \\
\hline $3 X-1,117-119$ & 19.97 & 1.731 & 2.709 & 58.0 \\
\hline $4 \mathrm{H}-1,31-33$ & 24.31 & 1.640 & 2.724 & 63.8 \\
\hline $4 \mathrm{H}-1,97-99$ & 24.97 & 1.633 & 2.710 & 63.8 \\
\hline $4 \mathrm{H}-2,45-47$ & 25.77 & 1.712 & 2.714 & 59.3 \\
\hline $4 \mathrm{H}-2,108-110$ & 26.40 & 1.672 & 2.792 & 63.3 \\
\hline $4 \mathrm{H}-3,38-40$ & 27.20 & 1.660 & 2.749 & 63.1 \\
\hline $4 \mathrm{H}-3,129-131$ & 28.11 & 1.609 & 2.699 & 65.1 \\
\hline $4 \mathrm{H}-4,21-23$ & 28.53 & 1.621 & 2.676 & 63.9 \\
\hline $4 \mathrm{H}-4,92-94$ & 29.24 & 1.703 & 2.715 & 59.9 \\
\hline $4 \mathrm{H}-6,20-22$ & 31.52 & 1.615 & 2.680 & 64.3 \\
\hline $4 \mathrm{H}-6,112-114$ & 32.44 & 1.635 & 2.707 & 63.7 \\
\hline $4 \mathrm{H}-7,31-33$ & 33.13 & 1.651 & 2.706 & 62.7 \\
\hline $5 \mathrm{H}-1,24-26$ & 33.74 & 1.697 & 2.757 & 61.2 \\
\hline $5 \mathrm{H}-1,121-123$ & 34.71 & 1.869 & 2.770 & 51.6 \\
\hline $5 \mathrm{H}-2,6-8$ & 35.06 & 1.743 & 2.782 & 59.1 \\
\hline $5 \mathrm{H}-2,98-100$ & 35.98 & 1.700 & 2.726 & 60.3 \\
\hline $5 \mathrm{H}-3,63-65$ & 37.05 & 1.818 & 2.826 & 56.0 \\
\hline $5 \mathrm{H}-3,112-114$ & 37.54 & 1.927 & 2.802 & 49.2 \\
\hline $5 \mathrm{H}-4,38-40$ & 38.30 & 1.699 & 2.753 & 61.0 \\
\hline $5 \mathrm{H}-4,116-118$ & 39.08 & 1.752 & 2.839 & 59.9 \\
\hline $5 \mathrm{H}-6,113-115$ & 42.05 & 1.755 & 2.744 & 57.5 \\
\hline $5 \mathrm{H}-7,40-42$ & 42.77 & 1.705 & 2.753 & 60.6 \\
\hline $6 \mathrm{H}-1,27-29$ & 43.27 & 1.729 & 2.758 & 59.4 \\
\hline $6 \mathrm{H}-1,128-130$ & 44.28 & 1.815 & 2.794 & 55.3 \\
\hline $6 \mathrm{H}-2,33-35$ & 44.83 & 1.768 & 2.818 & 58.5 \\
\hline $6 \mathrm{H}-2,124-126$ & 45.74 & 1.815 & 2.784 & 55.0 \\
\hline $6 \mathrm{H}-3,24-26$ & 46.24 & 1.793 & 2.774 & 56.0 \\
\hline $6 \mathrm{H}-3,103-105$ & 47.03 & 1.753 & 2.707 & 56.7 \\
\hline $6 \mathrm{H}-4,13-15$ & 47.63 & 1.894 & 2.924 & 54.2 \\
\hline $6 \mathrm{H}-4,124-126$ & 48.74 & 1.771 & 2.796 & 57.8 \\
\hline $6 \mathrm{H}-6,45-47$ & 50.95 & 1.732 & 2.739 & 58.7 \\
\hline $6 \mathrm{H}-7,15-17$ & 52.15 & 1.702 & 2.712 & 59.8 \\
\hline 7H-1, 34-36 & 52.84 & 1.900 & 2.789 & 50.4 \\
\hline 7H-1, 94-96 & 53.44 & 2.110 & 2.748 & 37.0 \\
\hline 7H-1, 142-144 & 53.92 & 1.896 & 2.734 & 49.0 \\
\hline 7H-2, 47-49 & 54.47 & 1.892 & 2.745 & 49.6 \\
\hline 7H-2, 118-120 & 55.18 & 1.923 & 2.793 & 49.2 \\
\hline 7H-3, 20-22 & 55.70 & 1.858 & 2.750 & 51.7 \\
\hline 7H-3, 80-82 & 56.30 & 2.023 & 2.745 & 41.9 \\
\hline
\end{tabular}

\begin{tabular}{|c|c|c|c|c|}
\hline \multirow{2}{*}{$\begin{array}{l}\text { Core, section, } \\
\text { interval }(\mathrm{cm})\end{array}$} & \multirow{2}{*}{$\begin{array}{l}\text { Depth } \\
\text { (mbsf) }\end{array}$} & \multicolumn{2}{|c|}{ Density $\left(\mathrm{g} / \mathrm{cm}^{3}\right)$} & \multirow{2}{*}{$\begin{array}{l}\text { Porosity } \\
(\%)\end{array}$} \\
\hline & & Bulk & Grain & \\
\hline 7H-3, 121-123 & 56.71 & 1.879 & 2.740 & 50.2 \\
\hline $7 \mathrm{H}-4,5-7$ & 57.05 & 1.907 & 2.756 & 49.0 \\
\hline $7 \mathrm{H}-4,66-68$ & 57.66 & 2.161 & 3.051 & 43.9 \\
\hline 7H-4, 113-115 & 58.13 & 2.243 & 2.718 & 28.1 \\
\hline $7 \mathrm{H}-6,8-10$ & 60.08 & 1.914 & 2.741 & 48.1 \\
\hline $7 \mathrm{H}-6,66-68$ & 60.66 & 1.946 & 2.766 & 47.1 \\
\hline 7H-6, 114-116 & 61.14 & 1.908 & 2.763 & 49.1 \\
\hline $7 \mathrm{H}-7,6-8$ & 61.32 & 1.887 & 2.732 & 49.5 \\
\hline $7 \mathrm{H}-7,62-64$ & 61.88 & 1.931 & 2.740 & 47.1 \\
\hline $8 \mathrm{H}-1,49-51$ & 62.49 & 2.104 & 2.749 & 37.4 \\
\hline $8 \mathrm{H}-1,80-82$ & 62.80 & 2.182 & 2.916 & 38.8 \\
\hline $8 \mathrm{H}-1,109-111$ & 63.09 & 1.854 & 2.754 & 52.0 \\
\hline $8 \mathrm{H}-2,17-19$ & 63.43 & 1.943 & 2.732 & 46.2 \\
\hline $8 \mathrm{H}-2,64-66$ & 63.90 & 1.975 & 2.771 & 45.6 \\
\hline $8 \mathrm{H}-2,113-115$ & 64.39 & 1.858 & 2.735 & 51.3 \\
\hline $8 \mathrm{H}-3,29-31$ & 65.05 & 1.912 & 2.750 & 48.6 \\
\hline $8 \mathrm{H}-3,103-105$ & 65.79 & 1.917 & 2.752 & 48.3 \\
\hline $8 \mathrm{H}-4,11-13$ & 66.37 & 1.971 & 2.737 & 44.7 \\
\hline $8 \mathrm{H}-4,51-53$ & 66.77 & 2.158 & 2.753 & 34.5 \\
\hline $8 \mathrm{H}-4,119-121$ & 67.45 & 1.961 & 2.765 & 46.2 \\
\hline $8 \mathrm{H}-5,50-52$ & 68.26 & 1.935 & 2.747 & 47.1 \\
\hline $8 \mathrm{H}-6,50-52$ & 69.76 & 1.941 & 2.776 & 47.7 \\
\hline $9 \mathrm{X}-1,38-40$ & 71.88 & 1.716 & 2.720 & 59.2 \\
\hline $9 X-1,109-111$ & 72.59 & 1.779 & 2.767 & 56.7 \\
\hline $10 X-1,13-15$ & 72.93 & 1.784 & 2.794 & 57.1 \\
\hline $10 X-1,105-107$ & 73.85 & 1.760 & 2.717 & 56.5 \\
\hline $10 X-2,15-17$ & 74.45 & 1.729 & 2.709 & 58.2 \\
\hline $10 X-2,86-88$ & 75.16 & 1.677 & 2.742 & 62.0 \\
\hline $10 X-2,136-138$ & 75.66 & 1.675 & 2.733 & 61.9 \\
\hline $10 X-3,17-19$ & 75.97 & 1.705 & 2.726 & 60.0 \\
\hline $10 \times-3,107-109$ & 76.87 & 1.708 & 2.731 & 59.9 \\
\hline $10 X-4,27-29$ & 77.57 & 1.766 & 2.751 & 57.1 \\
\hline $10 X-4,118-120$ & 78.48 & 1.799 & 2.740 & 54.8 \\
\hline $10 \times-6,7-9$ & 80.17 & 1.831 & 2.759 & 53.5 \\
\hline $10 X-6,66-68$ & 80.76 & 1.897 & 2.732 & 48.9 \\
\hline $10 X-6,128-130$ & 81.38 & 2.039 & 2.739 & 40.8 \\
\hline $10 X-7,12-14$ & 81.72 & 1.943 & 2.756 & 46.9 \\
\hline $12 X-1,49-51$ & 84.89 & 1.993 & 2.777 & 44.7 \\
\hline $12 X-1,110-112$ & 85.50 & 1.855 & 2.735 & 51.4 \\
\hline $12 X-2,38-40$ & 86.28 & 1.876 & 2.805 & 52.1 \\
\hline $12 X-3,27-29$ & 87.67 & 1.913 & 2.737 & 48.1 \\
\hline 12X-3, 99-101 & 88.39 & 2.024 & 2.769 & 42.7 \\
\hline $12 X-4,21-23$ & 89.11 & 1.930 & 2.762 & 47.8 \\
\hline $13 X-1,40-42$ & 93.30 & 1.893 & 2.747 & 49.6 \\
\hline $14 \mathrm{X}-1,109-111$ & 103.39 & 1.766 & 2.705 & 55.8 \\
\hline $14 X-2,50-52$ & 104.30 & 1.768 & 2.755 & 57.0 \\
\hline $14 \mathrm{X}-2,102-104$ & 104.82 & 1.757 & 2.687 & 55.9 \\
\hline $14 X-3,50-52$ & 105.80 & 1.790 & 2.794 & 56.7 \\
\hline $14 X-3,120-122$ & 106.50 & 1.935 & 2.717 & 46.2 \\
\hline $14 X-4,34-36$ & 107.14 & 2.009 & 2.763 & 43.3 \\
\hline $14 X-4,81-83$ & 107.61 & 2.039 & 2.754 & 41.4 \\
\hline $14 X-4,145-147$ & 108.25 & 1.945 & 2.767 & 47.1 \\
\hline $14 X-6,35-37$ & 109.98 & 1.863 & 2.708 & 50.2 \\
\hline $15 X-1,55-57$ & 112.25 & 1.974 & 2.781 & 46.0 \\
\hline $15 X-1,123-125$ & 112.93 & 1.977 & 2.719 & 43.8 \\
\hline $15 X-2,55-57$ & 113.75 & 2.003 & 2.784 & 44.4 \\
\hline $15 X-3,29-31$ & 114.99 & 2.147 & 2.818 & 37.4 \\
\hline $15 X-3,50-52$ & 115.20 & 1.946 & 2.792 & 47.9 \\
\hline $16 X-1,13-15$ & 121.43 & 1.789 & 2.738 & 55.4 \\
\hline $16 \mathrm{X}-1,128-130$ & 122.58 & 1.738 & 2.773 & 59.2 \\
\hline $16 X-2,47-49$ & 123.27 & 1.856 & 2.783 & 52.7 \\
\hline $16 X-3,40-42$ & 124.70 & 1.813 & 2.733 & 53.8 \\
\hline $16 X-4,16-18$ & 125.96 & 1.911 & 2.720 & 47.7 \\
\hline $16 X-5,10-12$ & 126.25 & 1.912 & 2.772 & 49.2 \\
\hline $16 \mathrm{X}-6,10-12$ & 126.75 & 1.921 & 2.741 & 47.8 \\
\hline $16 X-7,19-21$ & 128.34 & 1.845 & 2.737 & 52.1 \\
\hline $16 X-7,85-87$ & 129.00 & 1.855 & 2.792 & 53.0 \\
\hline $18 X-1,72-74$ & 131.62 & 1.723 & 2.728 & 59.0 \\
\hline
\end{tabular}


Table T9 (continued).

\begin{tabular}{|c|c|c|c|c|c|c|c|c|c|}
\hline \multirow{2}{*}{$\begin{array}{l}\text { Core, section, } \\
\text { interval }(\mathrm{cm})\end{array}$} & \multirow{2}{*}{$\begin{array}{l}\text { Depth } \\
\text { (mbsf) }\end{array}$} & \multicolumn{2}{|c|}{ Density $\left(\mathrm{g} / \mathrm{cm}^{3}\right)$} & \multirow{2}{*}{$\begin{array}{c}\text { Porosity } \\
\text { (\%) }\end{array}$} & \multirow{2}{*}{$\begin{array}{l}\text { Core, section, } \\
\text { interval }(\mathrm{cm})\end{array}$} & \multirow{2}{*}{$\begin{array}{l}\text { Depth } \\
\text { (mbsf) }\end{array}$} & \multicolumn{2}{|c|}{ Density $\left(\mathrm{g} / \mathrm{cm}^{3}\right)$} & \multirow{2}{*}{$\begin{array}{c}\text { Porosity } \\
\text { (\%) }\end{array}$} \\
\hline & & Bulk & Grain & & & & Bulk & Grain & \\
\hline $18 X-1,93-95$ & 131.83 & 1.795 & 2.716 & 54.4 & $8 X-2,13-15$ & 238.43 & 1.976 & 2.802 & 46.4 \\
\hline $18 X-2,5-7$ & 132.45 & 1.868 & 2.771 & 51.7 & $8 X-2,40-42$ & 238.70 & 2.065 & 2.773 & 40.5 \\
\hline $18 X-2,25-27$ & 132.65 & 1.846 & 2.783 & 53.3 & $8 X-4,82-84$ & 241.47 & 2.005 & 2.789 & 44.4 \\
\hline $19 X-1,44-46$ & 140.94 & 1.815 & 2.697 & 52.8 & $8 X-5,48-50$ & 242.28 & 2.000 & 2.742 & 43.2 \\
\hline $19 X-1,118-120$ & 141.68 & 1.736 & 2.680 & 57.0 & $8 X-5,83-85$ & 242.63 & 1.691 & 2.869 & 63.9 \\
\hline $19 X-2,11-13$ & 142.11 & 1.764 & 2.701 & 55.8 & $8 X-5,137-139$ & 243.17 & 1.970 & 2.773 & 45.9 \\
\hline $19 X-2,74-76$ & 142.74 & 1.874 & 2.716 & 49.7 & $8 X-6,36-38$ & 243.66 & 1.914 & 2.746 & 48.3 \\
\hline $19 X-2,135-137$ & 143.35 & 2.001 & 2.738 & 43.0 & $8 X-6,105-107$ & 244.35 & 1.943 & 2.801 & 48.2 \\
\hline $19 X-3,7-9$ & 143.57 & 1.913 & 2.738 & 48.2 & $8 X-7,14-16$ & 244.94 & 1.974 & 2.775 & 45.8 \\
\hline $19 X-4,21-23$ & 144.01 & 1.988 & 2.735 & 43.6 & $8 X-7,55-57$ & 245.35 & 2.109 & 2.780 & 38.2 \\
\hline $20 X-1,18-20$ & 150.38 & 1.931 & 2.772 & 48.1 & $9 X-1,12-14$ & 246.62 & 1.939 & 2.794 & 48.3 \\
\hline $20 X-1,95-97$ & 151.15 & 1.947 & 2.791 & 47.7 & $9 X-1,88-90$ & 247.38 & 2.070 & 2.747 & 39.3 \\
\hline $20 X-2,18-20$ & 151.88 & 1.994 & 2.779 & 44.8 & $9 X-1,141-143$ & 247.91 & 1.944 & 2.756 & 46.9 \\
\hline $20 X-2,113-115$ & 152.83 & 1.936 & 2.739 & 46.9 & $9 X-2,23-25$ & 248.23 & 2.020 & 2.774 & 43.1 \\
\hline $20 X-3,7-9$ & 153.27 & 1.859 & 2.761 & 51.9 & $9 X-2,90-92$ & 248.90 & 1.899 & 2.755 & 49.5 \\
\hline $20 X-3,35-37$ & 153.55 & 2.019 & 2.725 & 41.5 & $9 \times-4,29-31$ & 251.29 & 1.970 & 2.776 & 46.0 \\
\hline $20 X-4,8-10$ & 153.92 & 1.835 & 2.722 & 52.2 & $9 X-4,99-101$ & 251.99 & 2.100 & 2.756 & 37.9 \\
\hline $20 X-4,54-56$ & 154.38 & 2.037 & 2.692 & 39.3 & $9 X-5,22-24$ & 252.50 & 1.974 & 2.748 & 44.9 \\
\hline $20 X-4,93-95$ & 154.77 & 2.054 & 2.710 & 38.9 & $9 X-5,98-100$ & 253.26 & 2.027 & 2.791 & 43.2 \\
\hline $20 X-4,127-129$ & 155.11 & 1.974 & 2.739 & 44.6 & $9 X-5,136-138$ & 253.64 & 1.965 & 2.789 & 46.7 \\
\hline $20 X-6,24-26$ & 157.08 & 1.965 & 2.674 & 43.0 & $9 X-6,16-18$ & 253.94 & 2.058 & 2.774 & 40.9 \\
\hline $20 X-6,65-67$ & 157.49 & 1.903 & 2.690 & 47.2 & $9 X-6,75-77$ & 254.53 & 1.932 & 2.776 & 48.2 \\
\hline $20 x-6,114-116$ & 157.98 & 2.028 & 2.717 & 40.7 & $9 X-7,29-31$ & 255.07 & 2.185 & 2.769 & 33.5 \\
\hline $21 X-1,26-28$ & 160.06 & 1.985 & 2.735 & 43.8 & $10 P-1,43-45$ & 256.53 & 2.122 & 2.774 & 37.3 \\
\hline $21 X-3,22-24$ & 162.03 & 1.902 & 2.717 & 48.1 & $10 P-1,83-85$ & 256.93 & 2.141 & 2.879 & 39.8 \\
\hline $23 X-2,23-25$ & 172.13 & 2.020 & 2.726 & 41.5 & $11 X-1,24-26$ & 257.34 & 2.130 & 2.731 & 35.2 \\
\hline $23 X-2,26-28$ & 172.16 & 1.900 & 2.784 & 50.2 & $11 X-1,63-65$ & 257.73 & 1.936 & 2.789 & 48.4 \\
\hline $24 X-1,27-29$ & 179.27 & 1.938 & 2.744 & 46.9 & $11 X-1,106-108$ & 258.16 & 2.049 & 2.736 & 40.1 \\
\hline $24 X-1,84-86$ & 179.84 & 2.026 & 2.716 & 40.8 & $11 X-2,15-17$ & 258.75 & 2.066 & 2.785 & 40.8 \\
\hline $24 X-1,127-129$ & 180.27 & 1.955 & 2.731 & 45.5 & $11 X-2,87-89$ & 259.47 & 1.964 & 2.749 & 45.5 \\
\hline $24 X-2,32-34$ & 180.71 & 1.851 & 2.739 & 51.8 & $11 X-3,27-29$ & 260.37 & 1.965 & 2.787 & 46.6 \\
\hline $24 X-2,67-69$ & 181.06 & 1.947 & 2.726 & 45.8 & $11 X-3,78-80$ & 260.88 & 1.994 & 2.764 & 44.3 \\
\hline $24 X-2,113-115$ & 181.52 & 1.919 & 2.728 & 47.5 & $11 X-3,140-142$ & 261.50 & 2.007 & 2.774 & 43.8 \\
\hline $24 X-3,37-39$ & 182.14 & 1.909 & 2.719 & 47.8 & $11 X-5,86-88$ & 263.96 & 1.919 & 2.767 & 48.6 \\
\hline $24 X-3,87-89$ & 182.64 & 1.974 & 2.746 & 44.8 & $11 X-5,128-130$ & 264.38 & 2.060 & 2.773 & 40.8 \\
\hline $24 X-4,26-28$ & 183.53 & 1.784 & 2.708 & 54.9 & $11 X-6,11-13$ & 264.71 & 1.962 & 2.795 & 47.0 \\
\hline $24 X-4,85-87$ & 184.12 & 1.957 & 2.738 & 45.6 & $12 X-1,10-12$ & 265.90 & 1.934 & 2.756 & 47.5 \\
\hline $25 X-1,10-12$ & 188.90 & 1.821 & 2.692 & 52.2 & $12 X-1,58-60$ & 266.38 & 1.960 & 2.765 & 46.2 \\
\hline $25 X-1,23-25$ & 189.03 & 1.928 & 2.782 & 48.5 & $12 X-1,115-117$ & 266.95 & 1.913 & 2.856 & 51.5 \\
\hline $25 X-1,33-36$ & 189.13 & 1.971 & 2.751 & 45.2 & $12 X-2,18-20$ & 267.48 & 1.938 & 2.779 & 47.9 \\
\hline $26 \mathrm{E}-1,15-17$ & 197.55 & 2.116 & 2.773 & 37.6 & $12 X-2,63-65$ & 267.93 & 1.970 & 2.760 & 45.5 \\
\hline $26 \mathrm{E}-1,22-24$ & 197.62 & 2.118 & 2.742 & 36.3 & $12 X-2,100-102$ & 268.30 & 1.947 & 2.764 & 47.0 \\
\hline 28P-1, 27-29 & 206.37 & 1.883 & 2.773 & 50.9 & $12 X-4,24-26$ & 270.41 & 1.888 & 2.810 & 51.6 \\
\hline $28 \mathrm{P}-1,43-45$ & 206.53 & 1.872 & 2.775 & 51.5 & $12 X-4,82-84$ & 270.99 & 2.081 & 2.760 & 39.1 \\
\hline 311-U1325C- & & & & & $12 X-4,142-144$ & 271.59 & 1.951 & 2.752 & 46.4 \\
\hline $1 X-2,20-22$ & 190.50 & 1.891 & 2.727 & 49.1 & $12 X-5,12-14$ & 271.79 & 1.909 & 2.786 & 49.8 \\
\hline $1 X-2,127-129$ & 191.57 & 1.973 & 2.727 & 44.3 & $12 X-5,68-70$ & 272.35 & 2.008 & 2.772 & 43.7 \\
\hline $2 X-1,11-13$ & 198.51 & 2.065 & 2.839 & 42.6 & $13 X-1,8-10$ & 275.48 & 1.836 & 2.756 & 53.1 \\
\hline $3 X-C C, 4-6$ & 203.24 & 1.957 & 2.740 & 45.6 & 13X-CC, 12-14 & 275.70 & 2.075 & 2.717 & 37.9 \\
\hline $4 X-2,31-33$ & 209.55 & 1.843 & 2.770 & 53.1 & $14 X-3,29-31$ & 286.99 & 1.914 & 2.801 & 49.9 \\
\hline $4 X-2,68-70$ & 209.92 & 1.857 & 2.764 & 52.1 & $15 X-1,53-53$ & 295.23 & 1.959 & 2.785 & 46.9 \\
\hline $4 X-4,10-12$ & 211.02 & 1.970 & 2.764 & 45.6 & $15 X-1,130-132$ & 296.00 & 1.961 & 2.751 & 45.7 \\
\hline $4 X-4,66-68$ & 211.58 & 1.881 & 2.798 & 51.7 & $15 X-2,26-28$ & 296.40 & 1.927 & 2.737 & 47.3 \\
\hline $4 X-4,103-105$ & 211.95 & 1.886 & 2.828 & 52.2 & 311-U1325D- & & & & \\
\hline $6 X-3,13-15$ & 220.52 & 1.868 & 2.798 & 52.4 & $1 \mathrm{H}-1,14-16$ & 0.14 & 1.289 & 2.617 & 83.3 \\
\hline $6 X-3,78-80$ & 221.17 & 1.931 & 2.781 & 48.4 & $1 \mathrm{H}-1,30-32$ & 0.30 & 1.279 & 2.796 & 85.6 \\
\hline $6 X-4,15-17$ & 221.66 & 2.138 & 2.734 & 34.8 & $1 \mathrm{H}-1,65-67$ & 0.65 & 1.325 & 2.662 & 81.6 \\
\hline $6 X-4,90-92$ & 222.41 & 2.004 & 2.773 & 44.0 & $1 \mathrm{H}-1,92-94$ & 0.92 & 1.362 & 2.725 & 80.1 \\
\hline $7 X-2,58-60$ & 229.28 & 2.006 & 2.788 & 44.3 & $1 \mathrm{H}-1,111-113$ & 1.11 & 1.326 & 2.585 & 80.7 \\
\hline $7 X-2,127-129$ & 229.97 & 2.135 & 2.785 & 36.9 & $1 \mathrm{H}-2,27-29$ & 1.77 & 1.372 & 2.635 & 78.4 \\
\hline $7 X-3,56-58$ & 230.76 & 1.968 & 2.801 & 46.9 & $1 \mathrm{H}-2,56-58$ & 2.06 & 1.356 & 2.597 & 78.9 \\
\hline $7 X-3,74-76$ & 230.94 & 1.985 & 2.774 & 45.1 & $1 \mathrm{H}-2,87-89$ & 2.37 & 1.397 & 2.626 & 76.7 \\
\hline $7 X-5,18-20$ & 232.17 & 1.950 & 2.808 & 48.1 & $1 \mathrm{H}-2,118-120$ & 2.68 & 1.393 & 2.697 & 77.9 \\
\hline $7 X-6,59-61$ & 233.26 & 1.999 & 2.776 & 44.4 & $1 \mathrm{H}-3,15-17$ & 3.15 & 1.409 & 2.568 & 75.1 \\
\hline $7 X-6,82-84$ & 233.49 & 2.177 & 2.787 & 34.6 & $1 \mathrm{H}-3,45-47$ & 3.45 & 1.420 & 2.648 & 75.6 \\
\hline $7 X-7,52-54$ & 234.69 & 1.994 & 2.818 & 45.9 & $1 \mathrm{H}-3,79-81$ & 3.79 & 1.425 & 2.596 & 74.5 \\
\hline $8 X-1,15-17$ & 236.95 & 1.893 & 2.766 & 50.1 & $1 \mathrm{H}-3,106-108$ & 4.06 & 1.462 & 2.713 & 74.0 \\
\hline
\end{tabular}


Table T10. Compressional wave velocity, Holes U1325B and U1325D.

\begin{tabular}{|c|c|c|c|c|}
\hline \multirow{2}{*}{$\begin{array}{l}\text { Core, section, } \\
\text { interval }(\mathrm{cm})\end{array}$} & \multirow{2}{*}{$\begin{array}{l}\text { Depth } \\
\text { (mbsf) }\end{array}$} & \multicolumn{3}{|c|}{ Velocity $(\mathrm{m} / \mathrm{s})$} \\
\hline & & PWS1 & PWS2 & PWS3 \\
\hline \multicolumn{5}{|l|}{ 311-U1325B- } \\
\hline $1 \mathrm{H}-2,9$ & 1.59 & & & 1513.6 \\
\hline $1 \mathrm{H}-2,10$ & 1.60 & & 1495.7 & \\
\hline $1 \mathrm{H}-2,12$ & 1.62 & 1503.9 & & \\
\hline $1 \mathrm{H}-2,36$ & 1.86 & & 1505.5 & \\
\hline $1 \mathrm{H}-2,38$ & 1.88 & & & 1503.1 \\
\hline $1 \mathrm{H}-2,40$ & 1.90 & 1503.9 & & \\
\hline $1 \mathrm{H}-2,55$ & 2.05 & & 1492.5 & \\
\hline $1 \mathrm{H}-2,56$ & 2.06 & & & 1505.2 \\
\hline $1 \mathrm{H}-4,47$ & 4.97 & & & 1514.6 \\
\hline $1 \mathrm{H}-5,100$ & 7.00 & & & 1533.6 \\
\hline \multicolumn{5}{|l|}{ 311-U1325D- } \\
\hline $1 \mathrm{H}-1,11.7$ & 0.12 & & 1512.0 & \\
\hline $1 \mathrm{H}-1,12.3$ & 0.12 & 1507.2 & & \\
\hline $1 \mathrm{H}-1,14$ & 0.14 & & & 1497.9 \\
\hline $1 \mathrm{H}-1,21.2$ & 0.21 & & 1512.0 & \\
\hline $1 \mathrm{H}-1,21.9$ & 0.22 & 1505.5 & & \\
\hline $1 \mathrm{H}-1,24$ & 0.14 & & & 1504.3 \\
\hline $1 \mathrm{H}-1,30.9$ & 0.31 & 1510.5 & & \\
\hline $1 \mathrm{H}-1,31.4$ & 0.31 & & 1515.4 & \\
\hline $1 \mathrm{H}-1,34$ & 0.34 & & & 1505.7 \\
\hline $1 \mathrm{H}-1,40.7$ & 0.41 & & 1515.4 & \\
\hline $1 \mathrm{H}-1,41.5$ & 0.42 & 1507.2 & & \\
\hline $1 \mathrm{H}-1,44$ & 0.44 & & & 1526.0 \\
\hline $1 \mathrm{H}-1,49.4$ & 0.49 & & 1508.7 & \\
\hline $1 \mathrm{H}-1,49.9$ & 0.50 & 1505.5 & & \\
\hline $1 \mathrm{H}-1,54$ & 0.54 & & & 1498.2 \\
\hline $1 \mathrm{H}-1,59.2$ & 0.59 & & 1515.4 & \\
\hline $1 \mathrm{H}-1,60.2$ & 0.60 & 1507.2 & & \\
\hline $1 \mathrm{H}-1,64$ & 0.64 & & & 1504.5 \\
\hline $1 \mathrm{H}-1,71.6$ & 0.72 & & 1515.4 & \\
\hline $1 \mathrm{H}-1,71.8$ & 0.72 & 1507.2 & & \\
\hline $1 \mathrm{H}-1,74$ & 0.74 & & & 1496.8 \\
\hline $1 \mathrm{H}-1,81$ & 0.81 & & 1518.7 & \\
\hline $1 \mathrm{H}-1,81.6$ & 0.93 & 1507.2 & & \\
\hline $1 \mathrm{H}-1,84$ & 0.84 & & & 1507.7 \\
\hline $1 \mathrm{H}-1,91.9$ & 0.92 & & 1508.7 & \\
\hline $1 \mathrm{H}-1,92.9$ & 0.93 & 1505.5 & & \\
\hline $1 \mathrm{H}-1,94$ & 0.94 & & & 1499.1 \\
\hline $1 \mathrm{H}-1,102.4$ & 1.02 & & 1508.7 & \\
\hline $1 \mathrm{H}-1,102.6$ & 1.03 & 1508.8 & & \\
\hline $1 \mathrm{H}-1,104$ & 1.04 & & & 1514.8 \\
\hline $1 \mathrm{H}-1,111.8$ & 1.12 & & 1506.8 & \\
\hline $1 \mathrm{H}-1,111.9$ & 1.12 & 1505.5 & & \\
\hline $1 \mathrm{H}-1,114$ & 1.14 & & & 1489.1 \\
\hline $1 \mathrm{H}-1,118.8$ & 1.19 & 1503.9 & & \\
\hline $1 \mathrm{H}-1,120$ & 1.32 & & 1507.4 & \\
\hline $1 \mathrm{H}-1,124$ & 1.14 & & & 1513.3 \\
\hline $1 \mathrm{H}-1,132$ & 1.32 & & 1512.7 & \\
\hline $1 \mathrm{H}-1,134$ & 1.34 & & & 1491.1 \\
\hline $1 \mathrm{H}-2,9$ & 1.59 & & 1506.8 & \\
\hline $1 \mathrm{H}-2,9$ & 1.59 & & & 1496.0 \\
\hline $1 \mathrm{H}-2,10$ & 1.60 & 1507.2 & & \\
\hline $1 \mathrm{H}-2,19$ & 1.69 & & & 1492.9 \\
\hline $1 \mathrm{H}-2,20$ & 1.70 & & 1511.4 & \\
\hline $1 \mathrm{H}-2,21$ & 1.71 & 1507.2 & & \\
\hline $1 \mathrm{H}-2,29$ & 1.79 & & 1489.3 & \\
\hline $1 \mathrm{H}-2,29$ & 1.79 & & & 1496.1 \\
\hline
\end{tabular}

\begin{tabular}{|c|c|c|c|c|}
\hline \multirow{2}{*}{$\begin{array}{l}\text { Core, section, } \\
\text { interval }(\mathrm{cm})\end{array}$} & \multirow{2}{*}{$\begin{array}{l}\text { Depth } \\
\text { (mbsf) }\end{array}$} & \multicolumn{3}{|c|}{ Velocity $(\mathrm{m} / \mathrm{s})$} \\
\hline & & PWS1 & PWS2 & PWS3 \\
\hline $1 \mathrm{H}-2,31$ & 1.71 & 1508.2 & & \\
\hline $1 \mathrm{H}-2,37$ & 1.87 & & & 1495.0 \\
\hline $1 \mathrm{H}-2,40$ & 1.90 & & 1504.9 & \\
\hline $1 \mathrm{H}-2,41$ & 1.91 & 1510.4 & & \\
\hline $1 \mathrm{H}-2,49$ & 1.99 & & 1504.9 & \\
\hline $1 \mathrm{H}-2,49$ & 1.87 & & & 1493.5 \\
\hline $1 \mathrm{H}-2,51$ & 2.01 & 1505.7 & & \\
\hline $1 \mathrm{H}-2,57$ & 2.07 & & 1502.8 & \\
\hline $1 \mathrm{H}-2,58$ & 2.08 & & & 1494.4 \\
\hline $1 \mathrm{H}-2,61$ & 2.01 & 1507.2 & & \\
\hline $1 \mathrm{H}-2,68$ & 2.18 & & & 1492.0 \\
\hline $1 \mathrm{H}-2,71$ & 2.21 & & 1501.0 & \\
\hline $1 \mathrm{H}-2,72$ & 2.22 & 1508.8 & & \\
\hline $1 \mathrm{H}-2,77$ & 2.27 & & & 1493.6 \\
\hline $1 \mathrm{H}-2,80$ & 2.30 & & 1505.5 & \\
\hline $1 \mathrm{H}-2,82$ & 2.32 & 1506.3 & & \\
\hline $1 \mathrm{H}-2,88$ & 2.38 & & & 1485.1 \\
\hline $1 \mathrm{H}-2,90$ & 2.40 & & 1500.4 & \\
\hline $1 \mathrm{H}-2,92$ & 2.42 & 1504.1 & & \\
\hline $1 \mathrm{H}-2,98$ & 2.48 & & & 1492.4 \\
\hline $1 \mathrm{H}-2,101$ & 2.51 & & 1510.7 & \\
\hline $1 \mathrm{H}-2,103$ & 2.42 & 1503.9 & & \\
\hline $1 \mathrm{H}-2,118$ & 2.68 & & & 1492.8 \\
\hline $1 \mathrm{H}-2,120$ & 2.70 & & 1499.2 & \\
\hline $1 \mathrm{H}-2,124$ & 2.74 & 1497.4 & & \\
\hline $1 \mathrm{H}-2,130$ & 2.80 & & & 1482.5 \\
\hline $1 \mathrm{H}-3,7$ & 3.07 & & & 1494.8 \\
\hline $1 \mathrm{H}-3,10$ & 3.10 & 1508.8 & & \\
\hline $1 \mathrm{H}-3,17$ & 3.17 & & & 1499.7 \\
\hline $1 \mathrm{H}-3,21$ & 3.21 & 1503.9 & & \\
\hline $1 \mathrm{H}-3,27$ & 3.27 & & & 1503.1 \\
\hline $1 \mathrm{H}-3,28$ & 3.28 & & 1505.7 & \\
\hline $1 \mathrm{H}-3,31$ & 3.31 & 1508.8 & & \\
\hline $1 \mathrm{H}-3,37$ & 3.27 & & & 1497.8 \\
\hline $1 \mathrm{H}-3,38$ & 3.38 & & 1508.7 & \\
\hline $1 \mathrm{H}-3,40$ & 3.40 & 1512.1 & & \\
\hline $1 \mathrm{H}-3,47$ & 3.47 & & 1504.3 & \\
\hline $1 \mathrm{H}-3,47$ & 3.47 & & & 1492.4 \\
\hline $1 \mathrm{H}-3,50$ & 3.50 & 1507.2 & & \\
\hline $1 \mathrm{H}-3,56$ & 3.56 & & 1507.2 & \\
\hline $1 \mathrm{H}-3,57$ & 3.57 & & & 1488.7 \\
\hline $1 \mathrm{H}-3,60$ & 3.60 & 1512.1 & & \\
\hline $1 \mathrm{H}-3,67$ & 3.67 & & & 1503.6 \\
\hline $1 \mathrm{H}-3,70$ & 3.70 & & 1503.5 & \\
\hline $1 \mathrm{H}-3,73$ & 3.73 & 1507.2 & & \\
\hline $1 \mathrm{H}-3,73$ & 3.73 & 1508.8 & & \\
\hline $1 \mathrm{H}-3,76$ & 3.76 & & & 1504.6 \\
\hline $1 \mathrm{H}-3,86$ & 3.86 & & & 1491.1 \\
\hline $1 \mathrm{H}-3,90$ & 3.90 & & 1505.5 & \\
\hline $1 \mathrm{H}-3,93$ & 3.93 & 1507.2 & & \\
\hline $1 \mathrm{H}-3,98$ & 3.98 & & & 1491.3 \\
\hline $1 \mathrm{H}-3,100$ & 4.00 & & 1502.2 & \\
\hline $1 \mathrm{H}-3,103$ & 4.03 & 1506.9 & & \\
\hline $1 \mathrm{H}-3,108$ & 4.08 & & & 1488.8 \\
\hline $1 \mathrm{H}-3,111$ & 4.11 & & 1513.7 & \\
\hline $1 \mathrm{H}-3,113$ & 4.13 & 1507.2 & & \\
\hline $1 \mathrm{H}-3,122$ & 4.22 & & 1512.0 & \\
\hline $1 \mathrm{H}-3,125$ & 4.13 & 1507.2 & & \\
\hline
\end{tabular}

Note: PWS $=P$-wave sensor . 
Table T11. Torvane shear strength, Holes U1325B, U1325C, and U1325D. (See table note. Continued on next two pages.)

\begin{tabular}{|c|c|c|c|}
\hline $\begin{array}{l}\text { Core, section, } \\
\text { interval }(\mathrm{cm})\end{array}$ & $\begin{array}{l}\text { Depth } \\
\text { (mbsf) }\end{array}$ & $\begin{array}{l}\text { Torvane shear } \\
\text { strength }(\mathrm{kPa})\end{array}$ & $\begin{array}{l}\text { Torvane } \\
\text { size }\end{array}$ \\
\hline \multicolumn{4}{|l|}{ 311-U1325B- } \\
\hline $1 \mathrm{H}-2,15-17$ & 1.65 & 19 & M \\
\hline $1 \mathrm{H}-2,40-42$ & 1.9 & 18 & M \\
\hline $1 \mathrm{H}-2,61-63$ & 2.11 & 18 & M \\
\hline $1 \mathrm{H}-4,15-17$ & 4.65 & 18 & M \\
\hline $1 \mathrm{H}-4,41-43$ & 4.91 & 18 & M \\
\hline $1 \mathrm{H}-5,14-16$ & 6.14 & 22 & M \\
\hline $1 \mathrm{H}-5,58-60$ & 6.58 & 15 & M \\
\hline $1 \mathrm{H}-6,18-20$ & 7.68 & 20 & M \\
\hline $1 \mathrm{H}-6,39-41$ & 7.89 & 15 & M \\
\hline $1 \mathrm{H}-7,10-12$ & 9.10 & 10 & M \\
\hline $1 \mathrm{H}-7,20-27$ & 9.20 & 15 & M \\
\hline $2 \mathrm{H}-1,24-26$ & 9.54 & 5 & M \\
\hline $2 \mathrm{H}-1,103-105$ & 10.33 & 7 & M \\
\hline $2 \mathrm{H}-2,21-23$ & 11.01 & 17 & M \\
\hline $2 \mathrm{H}-2,111-113$ & 11.91 & 23 & M \\
\hline $2 \mathrm{H}-3,57-59$ & 12.87 & 8 & M \\
\hline $2 \mathrm{H}-4,13-15$ & 13.93 & 5 & M \\
\hline $2 \mathrm{H}-4,67-69$ & 14.47 & 6 & M \\
\hline $2 \mathrm{H}-4,112-114$ & 14.92 & 10 & M \\
\hline $2 \mathrm{H}-5,5-7$ & 15.35 & 28 & M \\
\hline $2 \mathrm{H}-5,83-85$ & 16.13 & 15 & M \\
\hline $2 \mathrm{H}-5,106-108$ & 16.36 & 24 & M \\
\hline $2 \mathrm{H}-5,140-142$ & 16.70 & 32 & M \\
\hline $2 \mathrm{H}-7,11-13$ & 18.41 & 32 & M \\
\hline $2 \mathrm{H}-7,72-74$ & 19.02 & 41 & M \\
\hline $3 X-1,22-24$ & 19.02 & 5 & M \\
\hline $3 X-1,112-114$ & 19.92 & 16 & M \\
\hline $4 \mathrm{H}-1,67-69$ & 24.67 & 37 & M \\
\hline $4 \mathrm{H}-2,90-92$ & 26.22 & 43 & M \\
\hline $4 \mathrm{H}-3,91-93$ & 27.73 & 32 & M \\
\hline $4 \mathrm{H}-4,107-109$ & 29.39 & 38 & M \\
\hline $4 \mathrm{H}-6,59-61$ & 31.91 & 45 & M \\
\hline $4 \mathrm{H}-7,56-58$ & 33.38 & 37 & M \\
\hline $5 \mathrm{H}-1,44-46$ & 33.94 & 80 & M \\
\hline $5 \mathrm{H}-1,39-41$ & 33.89 & 62.5 & $S$ \\
\hline $5 \mathrm{H}-2,53-55$ & 35.53 & 38 & M \\
\hline $5 \mathrm{H}-2,61-63$ & 35.61 & 45 & $S$ \\
\hline $5 \mathrm{H}-3,82-84$ & 37.24 & 29 & M \\
\hline $5 \mathrm{H}-3,86-88$ & 37.28 & 75 & $S$ \\
\hline $5 \mathrm{H}-3,75-77$ & 37.17 & 46 & M \\
\hline $5 \mathrm{H}-3,66-68$ & 37.08 & 72.5 & $S$ \\
\hline $5 \mathrm{H}-4,30-32$ & 38.22 & 45 & M \\
\hline $5 \mathrm{H}-4,35-37$ & 38.27 & 67.5 & $S$ \\
\hline $6 \mathrm{H}-1,57-59$ & 43.57 & 55 & M \\
\hline $6 \mathrm{H}-1,61-63$ & 43.61 & 70 & $S$ \\
\hline $6 \mathrm{H}-2,46-48$ & 44.96 & 50 & M \\
\hline $6 \mathrm{H}-3,35-37$ & 46.35 & 87.5 & $S$ \\
\hline $6 \mathrm{H}-4,39-41$ & 47.89 & 58 & M \\
\hline $6 \mathrm{H}-6,115-117$ & 51.65 & 50 & $S$ \\
\hline 7H-1, 38-40 & 52.88 & 71 & M \\
\hline 7H-1, 28-30 & 52.78 & 100 & $S$ \\
\hline 7H-1, 97-99 & 53.47 & 18 & M \\
\hline 7H-1, 89-91 & 53.39 & 152.5 & $S$ \\
\hline 7H-2, 51-53 & 54.51 & 67 & M \\
\hline $7 \mathrm{H}-2,56-58$ & 54.56 & 95 & $S$ \\
\hline 7H-2, 123-125 & 55.23 & 61 & M \\
\hline $7 \mathrm{H}-3,15-17$ & 55.65 & 137.5 & $S$ \\
\hline 7H-3, 26-28 & 55.76 & 27 & M \\
\hline 7H-3, 86-88 & 56.36 & 130 & $S$ \\
\hline 7H-3, 126-128 & 56.76 & 76 & M \\
\hline 7H-3, 129-131 & 56.79 & 125 & $S$ \\
\hline 7H-4, 11-13 & 57.11 & 100 & $S$ \\
\hline $7 \mathrm{H}-4,15-17$ & 57.15 & 85 & M \\
\hline 7H-4, 71-74 & 57.71 & 76 & M \\
\hline 7H-4, 75-77 & 57.75 & 87.5 & $S$ \\
\hline 7H-4, 106-108 & 58.06 & 55 & $S$ \\
\hline
\end{tabular}

\begin{tabular}{|c|c|c|c|}
\hline $\begin{array}{l}\text { Core, section, } \\
\text { interval }(\mathrm{cm})\end{array}$ & $\begin{array}{l}\text { Depth } \\
\text { (mbsf) }\end{array}$ & $\begin{array}{l}\text { Torvane shear } \\
\text { strength }(\mathrm{kPa})\end{array}$ & $\begin{array}{c}\text { Torvane } \\
\text { size }\end{array}$ \\
\hline 7H-4, 109-111 & 58.09 & 64 & M \\
\hline $7 \mathrm{H}-6,5-7$ & 60.05 & 94 & M \\
\hline $7 \mathrm{H}-6,2-4$ & 60.02 & 110 & s \\
\hline 7H-6, 110-112 & 61.10 & 100 & $S$ \\
\hline 7H-6, 118-120 & 61.18 & 96 & M \\
\hline $7 \mathrm{H}-7,3-5$ & 61.29 & 97.5 & $\mathrm{~s}$ \\
\hline $7 \mathrm{H}-7,12-14$ & 61.38 & 80 & M \\
\hline $7 \mathrm{H}-7,58-60$ & 61.84 & 72 & M \\
\hline $7 \mathrm{H}-7,66-68$ & 61.92 & 97.5 & s \\
\hline $8 \mathrm{H}-1,55-57$ & 62.55 & 80 & M \\
\hline $8 \mathrm{H}-1,78-80$ & 62.78 & 77 & M \\
\hline $8 \mathrm{H}-1,113-115$ & 63.13 & 27 & M \\
\hline $8 \mathrm{H}-2,30-32$ & 63.56 & 90 & M \\
\hline $8 \mathrm{H}-2,32-34$ & 63.58 & 87.5 & s \\
\hline $8 \mathrm{H}-2,68-70$ & 63.94 & 79 & M \\
\hline $8 \mathrm{H}-2,71-74$ & 63.97 & 80 & s \\
\hline $8 \mathrm{H}-3,33-35$ & 65.09 & 80 & $\mathrm{M}$ \\
\hline $8 \mathrm{H}-3,106-108$ & 65.82 & 70 & M \\
\hline $8 \mathrm{H}-3,110-112$ & 65.86 & 97.5 & s \\
\hline $8 \mathrm{H}-4,17-19$ & 66.43 & 90 & $M$ \\
\hline $8 \mathrm{H}-3,38-40$ & 65.14 & 75 & $\mathrm{~s}$ \\
\hline $8 \mathrm{H}-4,114-116$ & 67.40 & 100 & s \\
\hline $8 \mathrm{H}-6,55-57$ & 69.81 & 100 & $\mathrm{~s}$ \\
\hline $8 \mathrm{H}-6,60-62$ & 69.86 & 69 & M \\
\hline $8 \mathrm{H}-7,53-55$ & 70.79 & 54 & M \\
\hline $8 \mathrm{H}-7,59-61$ & 70.85 & 60 & $\mathrm{~s}$ \\
\hline $9 X-1,46-48$ & 71.96 & 44 & $\mathrm{M}$ \\
\hline $9 \times-1,117-119$ & 72.67 & 56 & M \\
\hline $9 X-1,42-44$ & 71.92 & 32.5 & $\mathrm{~s}$ \\
\hline $9 X-1,114-116$ & 72.64 & 67.5 & $\mathrm{~s}$ \\
\hline $10 X-1,20-22$ & 73.00 & 28 & M \\
\hline $10 X-1,109-110$ & 73.89 & 75 & M \\
\hline $10 \mathrm{X}-1,102-104$ & 73.82 & 100 & $\mathrm{~s}$ \\
\hline $10 X-2,18-20$ & 74.48 & 62.5 & s \\
\hline $10 \times-2,7-9$ & 74.37 & 65 & M \\
\hline $10 X-2,92-94$ & 75.22 & 55 & M \\
\hline $10 \times-2,97-99$ & 75.27 & 67.5 & s \\
\hline $10 X-2,130-132$ & 75.60 & 72.5 & $S$ \\
\hline $10 X-2,126-128$ & 75.56 & 52 & M \\
\hline $10 X-3,12-14$ & 75.92 & 55 & M \\
\hline $10 X-3,22-24$ & 76.02 & 65 & s \\
\hline $10 X-3,111-113$ & 76.91 & 87.5 & $\mathrm{~s}$ \\
\hline $10 X-3,102-104$ & 76.82 & 62 & M \\
\hline $10 X-4,19-21$ & 77.49 & 58 & M \\
\hline $10 X-4,33-35$ & 77.63 & 72.5 & s \\
\hline $10 X-4,124-126$ & 78.54 & 87.5 & $\mathrm{~s}$ \\
\hline $10 X-4,112-114$ & 78.42 & 74 & M \\
\hline $10 \times-6,11-13$ & 80.21 & 65 & $M$ \\
\hline $10 X-6,16-18$ & 80.26 & 62.5 & $\mathrm{~s}$ \\
\hline $10 X-6,61-63$ & 80.71 & 80 & M \\
\hline $10 X-6,58-60$ & 80.68 & 87.5 & s \\
\hline $12 X-1,92-94$ & 85.32 & 52 & M \\
\hline $12 X-2,31-33$ & 86.21 & 55 & M \\
\hline $12 X-2,28-30$ & 86.18 & 70 & $\mathrm{~s}$ \\
\hline $12 X-3,53-55$ & 87.93 & 78 & M \\
\hline $12 X-3,56-58$ & 87.96 & 100 & $\mathrm{~s}$ \\
\hline $12 X-4,40-42$ & 89.30 & 83 & M \\
\hline $12 X-4,44-46$ & 89.34 & 112.5 & s \\
\hline $14 \mathrm{X}-1,61-63$ & 102.91 & 38 & M \\
\hline $14 \mathrm{X}-1,48-50$ & 102.78 & 35 & s \\
\hline $14 \mathrm{X}-2,35-36$ & 104.15 & 45 & $S$ \\
\hline $14 X-2,90-92$ & 104.70 & 55 & M \\
\hline $14 X-3,58-60$ & 105.88 & 48 & M \\
\hline $14 X-3,63-65$ & 105.93 & 50 & s \\
\hline $14 X-4,137-139$ & 108.17 & 78 & M \\
\hline $14 X-4,128-130$ & 108.08 & 67.5 & $\mathrm{~s}$ \\
\hline $15 X-1,81-83$ & 112.51 & 52 & M \\
\hline
\end{tabular}


Table T11 (continued).

\begin{tabular}{|c|c|c|c|}
\hline $\begin{array}{l}\text { Core, section, } \\
\text { interval }(\mathrm{cm})\end{array}$ & $\begin{array}{l}\text { Depth } \\
\text { (mbsf) }\end{array}$ & $\begin{array}{l}\text { Torvane shear } \\
\text { strength }(\mathrm{kPa})\end{array}$ & $\begin{array}{c}\text { Torvane } \\
\text { size }\end{array}$ \\
\hline $15 X-1,106-108$ & 112.76 & 45 & S \\
\hline $15 X-2,41-43$ & 113.61 & 75 & S \\
\hline $15 X-2,45-47$ & 113.65 & 65 & M \\
\hline $15 X-3,39-41$ & 115.09 & 132.5 & $\mathrm{~s}$ \\
\hline $15 X-3,42-44$ & 115.12 & 95 & M \\
\hline $16 \mathrm{X}-1,43-45$ & 121.73 & 32.5 & s \\
\hline $16 \mathrm{X}-1,52-54$ & 121.82 & 20 & M \\
\hline $16 X-6,50-52$ & 127.15 & 45 & $\mathrm{~S}$ \\
\hline $16 X-6,53-55$ & 127.18 & 25 & M \\
\hline $18 X-2,37-39$ & 132.77 & 30 & $\mathrm{M}$ \\
\hline $18 \mathrm{X}-2,20-22$ & 132.60 & 42.5 & s \\
\hline $19 X-1,49-51$ & 140.99 & 65 & M \\
\hline $19 X-1,56-58$ & 141.06 & 75 & s \\
\hline $19 X-1,112-114$ & 141.62 & 87.5 & S \\
\hline $19 X-1,110-112$ & 141.60 & 75 & M \\
\hline $19 X-2,17-19$ & 142.17 & 44 & M \\
\hline $19 X-2,6-8$ & 142.06 & 87.5 & s \\
\hline $19 X-2,71-73$ & 142.71 & 62.5 & S \\
\hline $19 X-2,83-85$ & 142.83 & 64 & M \\
\hline $19 X-2,132-134$ & 143.32 & 34 & M \\
\hline $19 X-2,129-131$ & 143.29 & 72.5 & $\mathrm{~S}$ \\
\hline $19 X-3,12-14$ & 143.62 & 73 & M \\
\hline $19 X-5,18-20$ & 145.48 & 50 & M \\
\hline $20 X-1,101-103$ & 151.21 & 71 & M \\
\hline 20X-1, 92-94 & 151.12 & 62.5 & s \\
\hline $20 X-2,14-16$ & 151.84 & 80 & S \\
\hline $20 X-2,22-24$ & 151.92 & 60 & M \\
\hline $20 X-3,31-33$ & 153.51 & 75 & M \\
\hline $20 X-3,29-31$ & 153.49 & 75 & s \\
\hline $20 X-4,16-18$ & 154.00 & 117.5 & S \\
\hline $20 X-4,21-23$ & 154.05 & 80 & M \\
\hline $20 X-4,62-64$ & 154.46 & 125 & $S$ \\
\hline $20 X-4,98-100$ & 154.82 & 112.5 & S \\
\hline $20 X-4,100-102$ & 154.84 & 95 & M \\
\hline $20 \mathrm{X}-6,19-21$ & 157.03 & 105 & $\mathrm{~s}$ \\
\hline $20 X-6,27-29$ & 157.11 & 70 & M \\
\hline $20 X-6,74-76$ & 157.58 & 30 & M \\
\hline $20 X-6,71-73$ & 157.55 & 20 & s \\
\hline 20X-6, 109-111 & 157.93 & 87.5 & S \\
\hline $20 X-6,107-109$ & 157.91 & 90 & M \\
\hline $21 \mathrm{X}-1,22-24$ & 160.02 & 41 & M \\
\hline $21 X-1,15-17$ & 159.95 & 40 & $\mathrm{~S}$ \\
\hline $21 X-3,19-21$ & 162.00 & 50 & S \\
\hline $21 X-3,24-27$ & 162.05 & 54 & M \\
\hline $23 X-2,11-13$ & 172.01 & 34 & M \\
\hline $23 X-2,14-16$ & 172.04 & 17.5 & $S$ \\
\hline $23 X-2,31-33$ & 172.21 & 42.5 & s \\
\hline $23 \mathrm{X}-2,30-32$ & 172.20 & 43 & M \\
\hline $23 \mathrm{X}-2,46-48$ & 172.36 & 51 & M \\
\hline $24 X-1,55-57$ & 179.55 & 55 & M \\
\hline $24 \mathrm{X}-1,79-81$ & 179.79 & 50 & M \\
\hline $24 X-1,78-80$ & 179.78 & 62.5 & s \\
\hline $24 X-1,124-126$ & 180.24 & 70 & s \\
\hline $24 X-1,130-132$ & 180.30 & 73 & M \\
\hline $24 \mathrm{X}-2,37-39$ & 180.76 & 64 & M \\
\hline $24 X-2,40-42$ & 180.79 & 62.5 & s \\
\hline $24 X-2,64-66$ & 181.03 & 37.5 & S \\
\hline $24 X-2,61-63$ & 181.00 & 42 & M \\
\hline $24 \mathrm{X}-2,109-111$ & 181.48 & 75 & M \\
\hline $24 X-2,106-108$ & 181.45 & 75 & $S$ \\
\hline $24 X-3,33-35$ & 182.10 & 90 & S \\
\hline $24 X-3,41-43$ & 182.18 & 83 & M \\
\hline $24 X-3,80-81$ & 182.57 & 125 & s \\
\hline $24 X-4,30-32$ & 183.57 & 127.5 & $\mathrm{~s}$ \\
\hline $24 X-4,81-83$ & 184.08 & 107.5 & S \\
\hline $25 X-1,30-32$ & 189.10 & 30 & M \\
\hline $\begin{array}{r}311-U 1325 C- \\
1 X-2,30-32\end{array}$ & 190.60 & 85 & M \\
\hline
\end{tabular}

\begin{tabular}{|c|c|c|c|}
\hline $\begin{array}{l}\text { Core, section, } \\
\text { interval }(\mathrm{cm})\end{array}$ & $\begin{array}{l}\text { Depth } \\
\text { (mbsf) }\end{array}$ & $\begin{array}{l}\text { Torvane shear } \\
\text { strength }(\mathrm{kPa})\end{array}$ & $\begin{array}{l}\text { Torvane } \\
\text { size }\end{array}$ \\
\hline $1 X-2,26-28$ & 190.56 & 87.5 & $\mathrm{~s}$ \\
\hline $1 X-2,72-74$ & 191.02 & 70 & $\mathrm{~s}$ \\
\hline $1 \mathrm{X}-2,69-71$ & 190.99 & 77 & M \\
\hline $1 \mathrm{X}-2,131-133$ & 191.61 & 85 & M \\
\hline $1 \mathrm{X}-2,135-137$ & 191.65 & 87.5 & s \\
\hline $4 X-2,77-79$ & 210.01 & 57 & M \\
\hline $4 X-2,71-73$ & 209.95 & 67.5 & s \\
\hline $4 X-4,7-9$ & 210.99 & 35 & M \\
\hline $4 X-4,68-70$ & 211.60 & 65 & M \\
\hline $4 X-4,63-65$ & 211.55 & 50 & $\mathrm{~s}$ \\
\hline $4 X-4,84-86$ & 211.76 & 52.5 & $\mathrm{~s}$ \\
\hline $6 X-3,71-73$ & 221.10 & 33 & M \\
\hline $6 X-3,55-57$ & 220.94 & 57.5 & s \\
\hline $6 X-4,98-99$ & 222.49 & 150 & $\mathrm{~s}$ \\
\hline $6 X-4,32-34$ & 221.83 & 38 & M \\
\hline $6 X-4,69-70$ & 222.20 & 62.5 & $\mathrm{~s}$ \\
\hline $7 X-2,94-96$ & 229.64 & 45 & $\mathrm{~s}$ \\
\hline $7 X-2,83-85$ & 229.53 & 60 & M \\
\hline $7 X-3,16-18$ & 230.36 & 44 & M \\
\hline $7 X-3,9-11$ & 230.29 & 62.5 & s \\
\hline $7 X-4,33-35$ & 231.53 & 53 & M \\
\hline $7 X-4,21-23$ & 231.41 & 50 & $\mathrm{~s}$ \\
\hline $7 X-5,14-16$ & 232.13 & 33 & M \\
\hline $7 X-6,64-66$ & 233.31 & 45 & s \\
\hline $7 X-6,64-66$ & 233.31 & 41 & M \\
\hline $8 X-2,23-25$ & 238.53 & 125 & s \\
\hline $8 X-4,79-81$ & 241.44 & 107.5 & s \\
\hline $8 X-5,53-55$ & 242.33 & 165 & s \\
\hline $8 X-5,141-143$ & 243.21 & 100 & $S$ \\
\hline $8 X-6,31-33$ & 243.61 & 150 & s \\
\hline $8 X-7,31-33$ & 245.11 & 145 & $\mathrm{~s}$ \\
\hline $8 X-7,54-56$ & 245.34 & 17 & M \\
\hline $9 X-1,25-27$ & 246.75 & 72.5 & $\mathrm{~s}$ \\
\hline $9 X-1,85-87$ & 247.35 & 92.5 & $S$ \\
\hline $9 X-1,139-141$ & 247.89 & 62.5 & $\mathrm{~s}$ \\
\hline $9 X-1,36-38$ & 246.86 & 65 & M \\
\hline $9 X-2,27-29$ & 248.27 & 62.5 & $\mathrm{~s}$ \\
\hline $9 \mathrm{X}-2,18-20$ & 248.18 & 43 & M \\
\hline $9 X-3,34-36$ & 249.84 & 142.5 & $\mathrm{~s}$ \\
\hline $9 X-3,87-89$ & 250.37 & 50 & $\mathrm{~s}$ \\
\hline $9 X-3,87-89$ & 250.37 & 53 & $\mathrm{M}$ \\
\hline $9 X-4,25-27$ & 251.25 & 87.5 & s \\
\hline $9 X-4,126-128$ & 252.26 & 95 & $\mathrm{~s}$ \\
\hline $9 X-6,14-16$ & 253.92 & 37.5 & 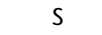 \\
\hline $9 X-5,16-18$ & 252.44 & 107.5 & $\mathrm{~s}$ \\
\hline $9 X-5,79-81$ & 253.07 & 62.5 & $\mathrm{~s}$ \\
\hline $9 X-7,28-30$ & 255.06 & 25 & $\mathrm{~s}$ \\
\hline $9 X-7,26-28$ & 255.04 & 45 & $\mathrm{M}$ \\
\hline $9 X-7,43-45$ & 255.21 & 107.5 & s \\
\hline $11 X-1,16-18$ & 257.26 & 13 & M \\
\hline $11 X-1,58-60$ & 257.68 & 75 & M \\
\hline $11 X-1,61-63$ & 257.71 & 95 & S \\
\hline $11 \mathrm{X}-1,103-105$ & 258.13 & 90 & 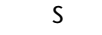 \\
\hline $11 X-2,11-13$ & 258.71 & 77.5 & $\mathrm{~s}$ \\
\hline $11 X-2,90-92$ & 259.50 & 72.5 & s \\
\hline $11 X-3,32-34$ & 260.42 & 82.5 & s \\
\hline $11 X-3,75-77$ & 260.85 & 90 & $S$ \\
\hline $11 X-3,135-137$ & 261.45 & 85 & $\mathrm{~s}$ \\
\hline $11 X-3,21-23$ & 260.31 & 70 & M \\
\hline $11 X-3,85-87$ & 260.95 & 88 & $\mathrm{M}$ \\
\hline $11 X-3,135-137$ & 261.45 & 95 & M \\
\hline $11 X-5,18-20$ & 263.28 & 92.5 & $\mathrm{~s}$ \\
\hline $11 X-5,79-81$ & 263.89 & 152.5 & s \\
\hline $11 X-6,20-22$ & 264.80 & 137.5 & $\mathrm{~s}$ \\
\hline $12 X-2,88-90$ & 268.18 & 87.5 & $\mathrm{~s}$ \\
\hline $15 X-2,16-18$ & 296.30 & 137.5 & $S$ \\
\hline \multicolumn{4}{|l|}{ 311-U1325D- } \\
\hline $1 \mathrm{H}-1,127-129$ & 1.27 & 5 & M \\
\hline
\end{tabular}


Table T11 (continued).

\begin{tabular}{lccc}
\hline $\begin{array}{c}\text { Core, section, } \\
\text { interval }(\mathrm{cm})\end{array}$ & $\begin{array}{c}\text { Depth } \\
(\mathrm{mbsf})\end{array}$ & $\begin{array}{c}\text { Torvane shear } \\
\text { strength }(\mathrm{kPa})\end{array}$ & $\begin{array}{c}\text { Torvane } \\
\text { size }\end{array}$ \\
\hline $1 \mathrm{H}-1,34-36$ & 0.34 & 1 & $\mathrm{~L}$ \\
$1 \mathrm{H}-1,130-134$ & 1.30 & 6 & $\mathrm{~L}$ \\
$1 \mathrm{H}-2,62-64$ & 2.12 & 15 & $\mathrm{M}$ \\
$1 \mathrm{H}-2,125-127$ & 2.75 & 16 & $\mathrm{M}$ \\
$1 \mathrm{H}-2,129-131$ & 2.79 & 11.8 & $\mathrm{~L}$ \\
$1 \mathrm{H}-3,28-30$ & 3.28 & 18 & $\mathrm{M}$ \\
$1 \mathrm{H}-3,121-123$ & 4.21 & 18 & $\mathrm{M}$ \\
\hline
\end{tabular}

Note: $\mathrm{L}=$ large $(4.8 \mathrm{~cm}$ diameter $), \mathrm{M}=$ medium $(2.5 \mathrm{~cm}$ diameter $), \mathrm{S}=$ small $(1.9 \mathrm{~cm}$ diameter $)$.

Table T12. AVS shear strength, Holes U1325B and U1325C.

\begin{tabular}{|c|c|c|c|c|}
\hline \multirow{2}{*}{$\begin{array}{l}\text { Core, section, } \\
\text { interval }(\mathrm{cm})\end{array}$} & \multirow{2}{*}{$\begin{array}{l}\text { Depth } \\
\text { (mbsf) }\end{array}$} & \multirow{2}{*}{$\begin{array}{l}\text { Vane } \\
\text { size }\end{array}$} & \multicolumn{2}{|c|}{ Shear strength $(\mathrm{kPa})$} \\
\hline & & & Peak & Residual \\
\hline \multicolumn{5}{|l|}{ 311-U1325B- } \\
\hline $1 \mathrm{H}-2,17$ & 1.67 & B & 13.4 & 11.4 \\
\hline $1 \mathrm{H}-2,45$ & 1.95 & B & 6.6 & 4.8 \\
\hline $1 \mathrm{H}-4,35$ & 4.85 & B & 17.0 & 16.0 \\
\hline $1 \mathrm{H}-4,58$ & 5.08 & B & 14.3 & 10.9 \\
\hline $1 \mathrm{H}-5,47$ & 6.47 & B & 14.6 & 11.7 \\
\hline $1 \mathrm{H}-6,29$ & 7.79 & B & 13.9 & 9.5 \\
\hline $1 \mathrm{H}-7,22$ & 9.22 & B & 9.7 & 7.3 \\
\hline $2 \mathrm{H}-2,15$ & 10.95 & B & 5.3 & 3.7 \\
\hline $2 \mathrm{H}-4,127$ & 15.07 & B & 14.13 & 11.6 \\
\hline $2 \mathrm{H}-5,35$ & 15.65 & B & 14.8 & 13.6 \\
\hline $2 \mathrm{H}-7,66$ & 18.96 & B & 15.6 & 11.9 \\
\hline $3 x-1,101$ & 19.81 & B & 14.1 & 11.0 \\
\hline $4 \mathrm{H}-1,43$ & 24.43 & B & 33.6 & 12.6 \\
\hline $4 \mathrm{H}-2,38$ & 25.70 & B & 39.2 & 16.5 \\
\hline $4 \mathrm{H}-3,139$ & 28.21 & B & 34.8 & 10.9 \\
\hline $4 \mathrm{H}-4,125$ & 29.57 & B & 29.7 & 8.8 \\
\hline $4 \mathrm{H}-6,97$ & 32.29 & B & 28.5 & 9.2 \\
\hline $5 \mathrm{H}-1,67$ & 34.17 & B & 74.9 & 24.3 \\
\hline $5 \mathrm{H}-2,45$ & 35.45 & B & 31.1 & 14.1 \\
\hline $5 \mathrm{H}-3,51$ & 36.93 & B & 40.8 & 19.0 \\
\hline $5 \mathrm{H}-4,26$ & 38.18 & B & 42.0 & 15.5 \\
\hline $6 \mathrm{H}-2,52$ & 45.02 & B & 45.4 & 10.4 \\
\hline $6 \mathrm{H}-3,56$ & 46.56 & B & 81.5 & 24.3 \\
\hline $6 \mathrm{H}-4,48$ & 47.98 & B & 67.3 & 21.6 \\
\hline $7 \mathrm{H}-1,32$ & 52.82 & B & 63.5 & 33.5 \\
\hline $7 \mathrm{H}-2,45$ & 54.45 & B & 39.4 & 25.7 \\
\hline $7 \mathrm{H}-3,37$ & 55.87 & B & 25.1 & 14.4 \\
\hline $8 \mathrm{H}-1,60$ & 62.60 & B & 74.2 & 48.8 \\
\hline $8 \mathrm{H}-3,81$ & 65.57 & B & 49.3 & 34.0 \\
\hline $8 \mathrm{H}-3,34$ & 65.10 & B & 43.3 & 28.5 \\
\hline $9 X-1,63$ & 72.13 & B & 37.9 & 30.1 \\
\hline $10 X-1,96$ & 73.76 & B & 47.6 & 32.6 \\
\hline $10 X-3,67$ & 76.47 & B & 44.2 & 30.8 \\
\hline $10 X-6,82$ & 80.92 & B & 42.1 & 32.4 \\
\hline $12 X-1,104$ & 85.44 & B & 39.9 & 32.3 \\
\hline $12 X-2,21$ & 86.11 & B & 34.1 & 26.8 \\
\hline $12 X-3,45$ & 87.85 & B & 69.1 & 22.4 \\
\hline $14 X-1,54$ & 102.84 & B & 30.8 & 11.7 \\
\hline $14 X-4,110$ & 107.90 & B & 115.9 & 31.3 \\
\hline $15 X-1,65$ & 112.35 & B & 30.1 & 18.9 \\
\hline $15 X-2,35$ & 113.55 & B & 61.3 & 25.1 \\
\hline $15 X-3,27$ & 114.97 & B & 48.6 & 21.2 \\
\hline $15 X-3,38$ & 115.08 & B & 108.4 & 25.3 \\
\hline $16 X-1,48$ & 121.78 & B & 22.3 & 5.9 \\
\hline $16 X-6,60$ & 127.25 & B & 31.4 & 13.3 \\
\hline $18 X-2,16$ & 132.56 & B & 27.2 & 18.5 \\
\hline
\end{tabular}

\begin{tabular}{|c|c|c|c|c|}
\hline \multirow{2}{*}{$\begin{array}{l}\text { Core, section, } \\
\text { interval }(\mathrm{cm})\end{array}$} & \multirow{2}{*}{$\begin{array}{l}\text { Depth } \\
\text { (mbsf) }\end{array}$} & \multirow{2}{*}{$\begin{array}{l}\text { Vane } \\
\text { size }\end{array}$} & \multicolumn{2}{|c|}{ Shear strength $(\mathrm{kPa})$} \\
\hline & & & Peak & Residual \\
\hline $18 \mathrm{X}-2,34$ & 132.74 & B & 27.9 & 22.8 \\
\hline $19 X-1,58$ & 141.08 & B & 75.3 & 54.9 \\
\hline $19 X-2,39$ & 142.39 & B & 61.0 & 45.4 \\
\hline $20 X-1,49$ & 150.69 & B & 29.6 & 24.5 \\
\hline $20 X-3,25$ & 153.45 & B & 69.7 & 56.9 \\
\hline $20 x-4,73$ & 154.57 & B & 83.4 & 69.5 \\
\hline $20 X-4,109$ & 154.93 & B & 20.4 & 14.0 \\
\hline $20 x-6,52$ & 157.36 & B & 93.1 & 68.3 \\
\hline $21 X-1,19$ & 159.99 & B & 23.6 & 20.6 \\
\hline $21 X-3,32$ & 162.13 & B & 34.8 & 23.6 \\
\hline $21 X-3,38$ & 162.19 & B & 57.4 & 36.9 \\
\hline $23 X-2,16$ & 172.06 & B & 13.4 & 9.9 \\
\hline $23 \mathrm{X}-2,44$ & 172.34 & B & 43.8 & 32.4 \\
\hline $24 X-1,86$ & 179.86 & B & 50.5 & 37.4 \\
\hline $24 X-2,51$ & 180.90 & B & 52.0 & 37.4 \\
\hline $24 X-4,62$ & 183.89 & B & 48.1 & 39.6 \\
\hline $24 X-5,41$ & 184.68 & B & 81.0 & 69.1 \\
\hline \multicolumn{5}{|l|}{ 311-U1325C- } \\
\hline $1 \mathrm{X}-2,95$ & 191.25 & B & 71.4 & 19.7 \\
\hline $4 X-2,75$ & 209.99 & B & 57.8 & 50.8 \\
\hline $4 X-4,84$ & 211.76 & B & 29.9 & 18.0 \\
\hline $6 X-3,51$ & 220.90 & B & 36.2 & 17.8 \\
\hline $6 X-4,57$ & 222.08 & B & 43.0 & 12.7 \\
\hline $6 X-4,98$ & 222.49 & B & 87.7 & 26.5 \\
\hline $7 X-2,98$ & 229.68 & B & 73.2 & 25.1 \\
\hline $7 X-3,37$ & 230.57 & B & 91.6 & 34.7 \\
\hline $7 X-6,52$ & 233.19 & B & 56.7 & 20.4 \\
\hline $7 X-7,51$ & 234.68 & B & 100.6 & 24.8 \\
\hline $8 X-2,22$ & 238.52 & B & 75.4 & 66.1 \\
\hline $8 X-6,45$ & 243.75 & B & 126.9 & 66.1 \\
\hline $8 X-7,26$ & 245.06 & B & 143.7 & 15.0 \\
\hline $8 X-7,54$ & 245.34 & B & 14.8 & 11.9 \\
\hline $9 X-1,57$ & 247.07 & B & 77.5 & 47.6 \\
\hline $9 X-2,75$ & 248.75 & B & 57.8 & 52.3 \\
\hline $9 X-4,66$ & 251.66 & B & 113.3 & 75.1 \\
\hline $9 X-5,71$ & 252.99 & B & 84.3 & 66.9 \\
\hline $9 X-7,46$ & 255.24 & B & 88.0 & 53.7 \\
\hline $11 X-1,29$ & 257.39 & B & 16.3 & 14.8 \\
\hline $11 X-1,71$ & 257.81 & B & 85.6 & 64.7 \\
\hline $11 X-3,40$ & 260.50 & A & 107.2 & 72.7 \\
\hline $11 X-5,40$ & 263.50 & A & 118.2 & 55.0 \\
\hline $11 X-6,30$ & 264.90 & A & 140.3 & 84.1 \\
\hline $12 X-1,30$ & 266.10 & A & 62.2 & 42.9 \\
\hline $12 X-4,102$ & 271.19 & A & 76.5 & 58.0 \\
\hline $12 X-5,40$ & 272.07 & A & 66.0 & 36.4 \\
\hline $15 X-2,24$ & 296.38 & A & 204.4 & 46.6 \\
\hline
\end{tabular}

Notes: $\mathrm{A}=$ small vane, $\mathrm{B}=$ medium vane. AVS values calibrated for spring constant used to calibrate shear strength. 
Table T13. Contact resistivity, Holes U1325B, U1325C, and U1325D. (Continued on next three pages.)

\begin{tabular}{|c|c|c|c|c|c|c|c|c|c|c|c|}
\hline $\begin{array}{l}\text { Core, section, } \\
\text { interval }(\mathrm{cm})\end{array}$ & $\begin{array}{l}\text { Depth } \\
\text { (mbsf) }\end{array}$ & $\begin{array}{l}\text { Resistivity } \\
(\Omega \mathrm{m})\end{array}$ & $\begin{array}{l}\text { Core, section, } \\
\text { interval }(\mathrm{cm})\end{array}$ & $\begin{array}{l}\text { Depth } \\
\text { (mbsf) }\end{array}$ & $\begin{array}{l}\text { Resistivity } \\
(\Omega \mathrm{m})\end{array}$ & $\begin{array}{l}\text { Core, section, } \\
\text { interval }(\mathrm{cm})\end{array}$ & $\begin{array}{l}\text { Depth } \\
\text { (mbsf) }\end{array}$ & $\begin{array}{c}\text { Resistivity } \\
(\Omega \mathrm{m})\end{array}$ & $\begin{array}{l}\text { Core, section, } \\
\text { interval }(\mathrm{cm})\end{array}$ & $\begin{array}{l}\text { Depth } \\
\text { (mbsf) }\end{array}$ & $\begin{array}{c}\text { Resistivity } \\
(\Omega \mathrm{m})\end{array}$ \\
\hline Parallel & & & $2 \mathrm{H}-5,80$ & 16.10 & 0.636 & $4 \mathrm{H}-3,134.1$ & 28.16 & 0.656 & $5 \mathrm{H}-6,117$ & 42.09 & 1.006 \\
\hline 311-U1325B- & & & $2 \mathrm{H}-5,90$ & 16.20 & 0.584 & $4 \mathrm{H}-3,142$ & 28.24 & 0.526 & $5 \mathrm{H}-6,126$ & 42.18 & 0.813 \\
\hline $1 \mathrm{H}-2,8$ & 1.58 & 0.515 & $2 \mathrm{H}-5,100$ & 16.30 & 0.581 & $4 \mathrm{H}-3,145$ & 28.27 & 0.581 & $5 \mathrm{H}-7,4$ & 42.41 & 0.657 \\
\hline $1 \mathrm{H}-2,28$ & 1.78 & 0.420 & $2 \mathrm{H}-5,111$ & 16.41 & 0.521 & $4 \mathrm{H}-4,12$ & 28.44 & 0.567 & $5 \mathrm{H}-7,7$ & 42.44 & 0.813 \\
\hline $1 \mathrm{H}-2,29$ & 1.79 & 0.409 & $2 \mathrm{H}-5,121$ & 16.51 & 0.607 & $4 \mathrm{H}-4,27$ & 28.59 & 0.676 & $5 \mathrm{H}-7,20$ & 42.57 & 0.718 \\
\hline $1 \mathrm{H}-2,39$ & 1.89 & 0.399 & $2 \mathrm{H}-5,133$ & 16.63 & 0.534 & $4 \mathrm{H}-4,44$ & 28.76 & 0.636 & $5 \mathrm{H}-7,29$ & 42.66 & 0.712 \\
\hline $1 \mathrm{H}-2,49$ & 1.99 & 0.373 & $2 \mathrm{H}-5,145$ & 16.75 & 0.572 & $4 \mathrm{H}-4,54$ & 28.86 & 0.621 & $5 \mathrm{H}-7,40$ & 42.77 & 0.657 \\
\hline $1 \mathrm{H}-2,65$ & 2.15 & 0.446 & $2 \mathrm{H}-5,107$ & 16.37 & 0.807 & $4 \mathrm{H}-4,68$ & 29.00 & 0.575 & $6 \mathrm{H}-1,7$ & 43.07 & 0.531 \\
\hline $1 \mathrm{H}-4,10$ & 4.60 & 0.613 & $2 \mathrm{H}-7,8$ & 18.38 & 0.586 & $4 \mathrm{H}-4,90$ & 29.22 & 0.620 & $6 \mathrm{H}-1,27$ & 43.27 & 0.523 \\
\hline $1 \mathrm{H}-4,23$ & 4.73 & 0.646 & $2 \mathrm{H}-7,31$ & 18.61 & 0.624 & $4 \mathrm{H}-4,113$ & 29.45 & 0.653 & $6 \mathrm{H}-1,47$ & 43.47 & 0.567 \\
\hline $1 \mathrm{H}-4,30$ & 4.80 & 0.533 & $2 \mathrm{H}-7,43$ & 18.73 & 0.598 & $4 \mathrm{H}-4,123$ & 29.55 & 0.681 & $6 \mathrm{H}-1,67$ & 43.67 & 0.614 \\
\hline $1 \mathrm{H}-4,40$ & 4.90 & 0.493 & $2 \mathrm{H}-7,58$ & 18.88 & 0.637 & $4 \mathrm{H}-4,130$ & 29.62 & 0.853 & $6 \mathrm{H}-1,87$ & 43.87 & 0.669 \\
\hline $1 \mathrm{H}-4,50$ & 5.00 & 0.517 & $2 \mathrm{H}-7,71$ & 19.01 & 0.596 & $4 \mathrm{H}-4,143$ & 29.75 & 0.699 & $6 \mathrm{H}-1,113$ & 44.13 & 0.572 \\
\hline $1 \mathrm{H}-4,62$ & 5.12 & 0.485 & $2 \mathrm{H}-7,82$ & 19.12 & 0.642 & $4 \mathrm{H}-6,10$ & 31.42 & 0.662 & $6 \mathrm{H}-1,133$ & 44.33 & 0.664 \\
\hline $1 \mathrm{H}-5,7$ & 6.07 & 0.733 & $3 X-1,9$ & 18.89 & 0.799 & $4 \mathrm{H}-6,30$ & 31.62 & 0.736 & $6 \mathrm{H}-2,14$ & 44.64 & 0.515 \\
\hline $1 \mathrm{H}-5,19$ & 6.19 & 0.546 & $3 X-1,19$ & 18.99 & 0.604 & $4 \mathrm{H}-6,50$ & 31.82 & 0.633 & $6 \mathrm{H}-2,34$ & 44.84 & 0.529 \\
\hline $1 \mathrm{H}-5,32$ & 6.32 & 0.763 & $3 X-1,29$ & 19.09 & 0.742 & $4 \mathrm{H}-6,70$ & 32.02 & 0.810 & $6 \mathrm{H}-2,54$ & 45.04 & 0.735 \\
\hline $1 \mathrm{H}-5,42$ & 6.42 & 0.618 & $3 X-1,39$ & 19.19 & 0.786 & $4 \mathrm{H}-6,90$ & 32.22 & 0.615 & $6 \mathrm{H}-2,74$ & 45.24 & 0.625 \\
\hline $1 \mathrm{H}-5,53$ & 6.53 & 0.522 & $3 X-1,49$ & 19.29 & 0.534 & $4 \mathrm{H}-6,110$ & 32.42 & 0.691 & $6 \mathrm{H}-2,94$ & 45.44 & 0.607 \\
\hline $1 \mathrm{H}-5,63$ & 6.63 & 0.427 & $3 X-1,59$ & 19.39 & 0.716 & $4 \mathrm{H}-6,130$ & 32.62 & 0.731 & $6 \mathrm{H}-2,125$ & 45.75 & 0.533 \\
\hline $1 \mathrm{H}-6,15$ & 7.65 & 0.630 & $3 X-1,69$ & 19.49 & 0.769 & $4 \mathrm{H}-6,147$ & 32.79 & 0.631 & $6 \mathrm{H}-3,25$ & 46.25 & 0.551 \\
\hline $1 \mathrm{H}-6,25$ & 7.75 & 0.602 & $3 X-1,79$ & 19.59 & 0.494 & $4 \mathrm{H}-7,10$ & 32.92 & 0.888 & $6 \mathrm{H}-3,45$ & 46.45 & 0.535 \\
\hline $1 \mathrm{H}-6,35$ & 7.85 & 0.717 & $3 X-1,89$ & 19.69 & 0.476 & $4 \mathrm{H}-7,30$ & 33.12 & 0.680 & $6 \mathrm{H}-3,65$ & 46.65 & 0.571 \\
\hline $1 \mathrm{H}-6,45$ & 7.95 & 0.676 & $3 X-1,99$ & 19.79 & 0.427 & $4 \mathrm{H}-7,50$ & 33.32 & 0.938 & $6 \mathrm{H}-3,85$ & 46.85 & 0.492 \\
\hline $1 \mathrm{H}-6,55$ & 8.05 & 0.725 & $3 X-1,109$ & 19.89 & 0.435 & $4 \mathrm{H}-7,50$ & 33.32 & 0.871 & $6 \mathrm{H}-3,105$ & 47.05 & 0.536 \\
\hline $1 \mathrm{H}-6,62$ & 8.12 & 0.557 & $3 \mathrm{X}-1,119$ & 19.99 & 0.424 & $4 \mathrm{H}-7,60$ & 33.42 & 0.652 & $6 \mathrm{H}-3,125$ & 47.25 & 0.529 \\
\hline $1 \mathrm{H}-7,8$ & 9.08 & 0.711 & $3 X-1,139$ & 20.19 & 0.471 & $5 \mathrm{H}-1,10$ & 33.60 & 0.596 & $6 \mathrm{H}-3,145$ & 47.45 & 0.517 \\
\hline $1 \mathrm{H}-7,15$ & 9.15 & 0.795 & $3 X-1,147$ & 20.27 & 0.512 & $5 \mathrm{H}-1,10$ & 33.60 & 0.664 & $6 \mathrm{H}-4,16$ & 47.66 & 0.610 \\
\hline $1 \mathrm{H}-7,21$ & 9.21 & 0.717 & $4 \mathrm{H}-1,3$ & 24.03 & 0.522 & $5 \mathrm{H}-1,30$ & 33.80 & 0.586 & $6 \mathrm{H}-4,36$ & 47.86 & 0.512 \\
\hline $1 \mathrm{H}-7,31$ & 9.31 & 0.640 & $4 \mathrm{H}-1,8$ & 24.08 & 0.608 & $5 \mathrm{H}-1,50$ & 34.00 & 0.647 & $6 \mathrm{H}-4,56$ & 48.06 & 1.263 \\
\hline $2 \mathrm{H}-1,19$ & 9.49 & 0.504 & $4 \mathrm{H}-1,20$ & 24.20 & 0.600 & $5 \mathrm{H}-1,70$ & 34.20 & 0.641 & $6 \mathrm{H}-4,76$ & 48.26 & 0.457 \\
\hline $2 \mathrm{H}-1,41$ & 9.71 & 0.803 & $4 \mathrm{H}-1,24$ & 24.24 & 0.484 & $5 \mathrm{H}-1,90$ & 34.40 & 0.668 & $6 \mathrm{H}-4,96$ & 48.46 & 0.477 \\
\hline $2 \mathrm{H}-1,69$ & 9.99 & 0.813 & $4 \mathrm{H}-1,34$ & 24.34 & 0.603 & $5 \mathrm{H}-1,103$ & 34.53 & 0.767 & $6 \mathrm{H}-4,116$ & 48.66 & 0.677 \\
\hline $2 \mathrm{H}-1,93$ & 10.23 & 0.797 & $4 \mathrm{H}-1,44$ & 24.44 & 0.656 & $5 \mathrm{H}-1,115$ & 34.65 & 0.638 & $6 \mathrm{H}-4,136$ & 48.86 & 0.524 \\
\hline $2 \mathrm{H}-1,103$ & 10.33 & 0.457 & $4 \mathrm{H}-1,54$ & 24.54 & 0.603 & $5 \mathrm{H}-1,122$ & 34.72 & 0.932 & $6 \mathrm{H}-6,10$ & 50.60 & 0.599 \\
\hline $2 \mathrm{H}-1,130$ & 10.60 & 0.696 & $4 \mathrm{H}-1,64$ & 24.64 & 0.513 & $5 \mathrm{H}-1,125$ & 34.75 & 0.645 & $6 \mathrm{H}-6,30$ & 50.80 & 0.573 \\
\hline $2 \mathrm{H}-2,6$ & 10.86 & 1.338 & $4 \mathrm{H}-1,74$ & 24.74 & 0.650 & $5 \mathrm{H}-1,143$ & 34.93 & 0.576 & $6 \mathrm{H}-6,50$ & 51.00 & 0.603 \\
\hline $2 \mathrm{H}-2,16$ & 10.96 & 0.619 & $4 \mathrm{H}-1,84$ & 24.84 & 0.515 & $5 \mathrm{H}-2,6$ & 35.06 & 0.658 & $6 \mathrm{H}-6,84$ & 51.34 & 0.478 \\
\hline $2 \mathrm{H}-2,33$ & 11.13 & 0.675 & $4 \mathrm{H}-1,94$ & 24.94 & 0.605 & $5 \mathrm{H}-2,9$ & 35.09 & 0.729 & $6 \mathrm{H}-6,112$ & 51.62 & 0.608 \\
\hline $2 \mathrm{H}-2,55$ & 11.35 & 0.821 & $4 \mathrm{H}-1,104$ & 25.04 & 0.601 & $5 \mathrm{H}-2,40$ & 35.40 & 0.642 & $6 \mathrm{H}-6,132$ & 51.82 & 0.699 \\
\hline $2 \mathrm{H}-2,79$ & 11.59 & 0.610 & $4 \mathrm{H}-1,114$ & 25.14 & 0.565 & $5 \mathrm{H}-2,48$ & 35.48 & 0.856 & $7 \mathrm{H}-1,15$ & 52.65 & 0.903 \\
\hline $2 \mathrm{H}-2,108$ & 11.88 & 0.508 & $4 \mathrm{H}-1,124$ & 25.24 & 0.565 & $5 \mathrm{H}-2,55$ & 35.55 & 0.692 & $7 \mathrm{H}-1,35$ & 52.85 & 0.953 \\
\hline $2 \mathrm{H}-2,120$ & 12.00 & 0.650 & $4 \mathrm{H}-2,10$ & 25.42 & 0.686 & $5 \mathrm{H}-2,62$ & 35.62 & 0.647 & $7 \mathrm{H}-1,35$ & 52.85 & 0.967 \\
\hline $2 \mathrm{H}-2,130$ & 12.10 & 0.532 & $4 \mathrm{H}-2,20$ & 25.52 & 0.601 & $5 \mathrm{H}-2,84$ & 35.84 & 0.688 & $7 \mathrm{H}-1,45$ & 52.95 & 1.022 \\
\hline $2 \mathrm{H}-2,134$ & 12.14 & 1.082 & $4 \mathrm{H}-2,30$ & 25.62 & 0.590 & $5 \mathrm{H}-2,88.5$ & 35.88 & 1.194 & $7 \mathrm{H}-1,55$ & 53.05 & 0.797 \\
\hline $2 \mathrm{H}-3,17$ & 12.47 & 0.620 & $4 \mathrm{H}-2,40$ & 25.72 & 0.578 & $5 \mathrm{H}-2,98$ & 35.98 & 0.665 & $7 \mathrm{H}-1,87$ & 53.37 & 0.816 \\
\hline $2 \mathrm{H}-3,57$ & 12.87 & 0.545 & $4 \mathrm{H}-2,45$ & 25.77 & 0.865 & $5 \mathrm{H}-2,118$ & 36.18 & 0.686 & $7 \mathrm{H}-1,95$ & 53.45 & 1.220 \\
\hline $2 \mathrm{H}-3,70$ & 13.00 & 0.705 & $4 \mathrm{H}-2,55$ & 25.87 & 0.679 & $5 \mathrm{H}-3,5$ & 36.47 & 0.654 & 7H-1, 112 & 53.62 & 1.015 \\
\hline $2 \mathrm{H}-3,89$ & 13.19 & 0.522 & $4 \mathrm{H}-2,65$ & 25.97 & 0.600 & $5 \mathrm{H}-3,25$ & 36.67 & 0.654 & $7 \mathrm{H}-1,122$ & 53.72 & 1.008 \\
\hline $2 \mathrm{H}-3,104$ & 13.34 & 0.580 & $4 \mathrm{H}-2,75$ & 26.07 & 0.554 & $5 \mathrm{H}-3,20$ & 36.62 & 1.057 & 7H-1, 132 & 53.82 & 0.997 \\
\hline $2 \mathrm{H}-3,133$ & 13.63 & 0.534 & $4 \mathrm{H}-2,85$ & 26.17 & 0.550 & $5 \mathrm{H}-3,40$ & 36.82 & 1.050 & $7 \mathrm{H}-1,143$ & 53.93 & 1.010 \\
\hline $2 \mathrm{H}-4,17$ & 13.97 & 0.658 & $4 \mathrm{H}-2,95$ & 26.27 & 0.605 & $5 \mathrm{H}-3,35$ & 36.77 & 0.604 & $7 \mathrm{H}-2,8$ & 54.08 & 1.016 \\
\hline $2 \mathrm{H}-4,53$ & 14.33 & 0.569 & $4 \mathrm{H}-2,105$ & 26.37 & 0.664 & $5 \mathrm{H}-3,55$ & 36.97 & 0.688 & 7H-2, 18 & 54.18 & 1.032 \\
\hline $2 \mathrm{H}-4,63$ & 14.43 & 0.571 & $4 \mathrm{H}-2,115$ & 26.47 & 0.636 & $5 \mathrm{H}-3,75$ & 37.17 & 0.707 & $7 \mathrm{H}-2,28$ & 54.28 & 0.993 \\
\hline $2 \mathrm{H}-4,73$ & 14.53 & 0.604 & $4 \mathrm{H}-2,125$ & 26.57 & 0.558 & $5 \mathrm{H}-3,79$ & 37.21 & 1.130 & $7 \mathrm{H}-2,38$ & 54.38 & 0.948 \\
\hline $2 \mathrm{H}-4,83$ & 14.63 & 0.588 & $4 \mathrm{H}-3,10$ & 26.92 & 0.611 & $5 \mathrm{H}-3,106$ & 37.48 & 0.681 & $7 \mathrm{H}-2,48$ & 54.48 & 1.003 \\
\hline $2 \mathrm{H}-4,97$ & 14.77 & 0.546 & $4 \mathrm{H}-3,20$ & 27.02 & 0.705 & $5 \mathrm{H}-3,115$ & 37.57 & 0.850 & $7 \mathrm{H}-2,58$ & 54.58 & 1.078 \\
\hline $2 \mathrm{H}-4,109$ & 14.89 & 0.663 & $4 \mathrm{H}-3,30$ & 27.12 & 0.660 & $5 \mathrm{H}-3,136$ & 37.78 & 0.670 & $7 \mathrm{H}-2,68$ & 54.68 & 1.074 \\
\hline $2 \mathrm{H}-4,121$ & 15.01 & 0.826 & $4 \mathrm{H}-3,40$ & 27.22 & 0.607 & $5 \mathrm{H}-3,143.5$ & 37.85 & 0.632 & $7 \mathrm{H}-2,78$ & 54.78 & 0.905 \\
\hline $2 \mathrm{H}-4,131$ & 15.11 & 0.701 & $4 \mathrm{H}-3,48$ & 27.30 & 0.653 & $5 \mathrm{H}-4,10$ & 38.02 & 0.669 & $7 \mathrm{H}-2,88$ & 54.88 & 1.024 \\
\hline $2 \mathrm{H}-4,141$ & 15.21 & 0.548 & $4 \mathrm{H}-3,58$ & 27.40 & 0.547 & $5 \mathrm{H}-4,20$ & 38.12 & 0.740 & $7 \mathrm{H}-2,98$ & 54.98 & 1.013 \\
\hline $2 \mathrm{H}-4,149$ & 15.29 & 0.620 & $4 \mathrm{H}-3,68$ & 27.50 & 0.651 & $5 \mathrm{H}-4,40$ & 38.32 & 0.563 & 7H-2, 108 & 55.08 & 0.999 \\
\hline $2 \mathrm{H}-5,10$ & 15.40 & 0.625 & $4 \mathrm{H}-3,78$ & 27.60 & 0.719 & $5 \mathrm{H}-4,63$ & 38.55 & 0.544 & 7H-2, 119 & 55.19 & 1.328 \\
\hline $2 \mathrm{H}-5,20$ & 15.50 & 1.291 & $4 \mathrm{H}-3,84$ & 27.66 & 0.702 & $5 \mathrm{H}-4,83$ & 38.75 & 0.649 & $7 \mathrm{H}-2,132$ & 55.32 & 1.007 \\
\hline $2 \mathrm{H}-5,30$ & 15.60 & 0.450 & $4 \mathrm{H}-3,84.1$ & 27.66 & 0.569 & $5 \mathrm{H}-4,103$ & 38.95 & 0.800 & $7 \mathrm{H}-3,10$ & 55.60 & 0.788 \\
\hline $2 \mathrm{H}-5,40$ & 15.70 & 0.543 & $4 \mathrm{H}-3,94.1$ & 27.76 & 0.607 & $5 \mathrm{H}-4,125.5$ & 39.17 & 0.527 & $7 \mathrm{H}-3,20$ & 55.70 & 0.998 \\
\hline $2 \mathrm{H}-5,50$ & 15.80 & 0.465 & $4 \mathrm{H}-3,104.1$ & 27.86 & 0.613 & $5 \mathrm{H}-6,6$ & 40.98 & 0.550 & $7 \mathrm{H}-3,30$ & 55.80 & 1.106 \\
\hline $2 \mathrm{H}-5,60$ & 15.90 & 0.590 & $4 \mathrm{H}-3,114.1$ & 27.96 & 0.634 & $5 \mathrm{H}-6,26$ & 41.18 & 0.646 & $7 \mathrm{H}-3,40$ & 55.90 & 0.943 \\
\hline $2 \mathrm{H}-5,70$ & 16.00 & 0.621 & $4 \mathrm{H}-3,124.1$ & 28.06 & 0.636 & $5 \mathrm{H}-6,107$ & 41.99 & 0.767 & $7 \mathrm{H}-3,50$ & 56.00 & 0.816 \\
\hline
\end{tabular}


Table T13 (continued).

\begin{tabular}{|c|c|c|c|c|c|c|c|c|c|c|c|}
\hline $\begin{array}{l}\text { Core, section, } \\
\text { interval }(\mathrm{cm})\end{array}$ & $\begin{array}{l}\text { Depth } \\
\text { (mbsf) }\end{array}$ & $\begin{array}{l}\text { Resistivity } \\
(\Omega \mathrm{m})\end{array}$ & $\begin{array}{l}\text { Core, section, } \\
\text { interval }(\mathrm{cm})\end{array}$ & $\begin{array}{l}\text { Depth } \\
\text { (mbsf) }\end{array}$ & $\begin{array}{l}\text { Resistivity } \\
(\Omega \mathrm{m})\end{array}$ & $\begin{array}{l}\text { Core, section, } \\
\text { interval }(\mathrm{cm})\end{array}$ & $\begin{array}{l}\text { Depth } \\
\text { (mbsf) }\end{array}$ & $\begin{array}{l}\text { Resistivity } \\
(\Omega \mathrm{m})\end{array}$ & $\begin{array}{l}\text { Core, section, } \\
\text { interval }(\mathrm{cm})\end{array}$ & $\begin{array}{l}\text { Depth } \\
\text { (mbsf) }\end{array}$ & $\begin{array}{l}\text { Resistivity } \\
(\Omega \mathrm{m})\end{array}$ \\
\hline $7 \mathrm{H}-3,60$ & 56.10 & 0.916 & $8 \mathrm{H}-3,45$ & 65.21 & 0.931 & $10 x-3,17$ & 75.97 & 0.599 & $12 X-3,104$ & 88.44 & 0.981 \\
\hline $7 \mathrm{H}-3,70$ & 56.20 & 0.887 & $8 \mathrm{H}-3,55$ & 65.31 & 0.968 & $10 X-3,27$ & 76.07 & 0.613 & $12 X-3,114$ & 88.54 & 1.103 \\
\hline $7 \mathrm{H}-3,80$ & 56.30 & 1.023 & $8 \mathrm{H}-3,78$ & 65.54 & 1.017 & $10 x-3,37$ & 76.17 & 0.678 & $12 X-3,124$ & 88.64 & 0.930 \\
\hline $7 \mathrm{H}-3,90$ & 56.40 & 0.988 & $8 \mathrm{H}-3,88$ & 65.64 & 1.062 & $10 x-3,47$ & 76.27 & 0.627 & $12 X-3,134$ & 88.74 & 0.846 \\
\hline $7 \mathrm{H}-3,100$ & 56.50 & 0.934 & $8 \mathrm{H}-3,104$ & 65.80 & 0.785 & $10 X-3,57$ & 76.37 & 0.644 & $12 X-3,144$ & 88.84 & 1.020 \\
\hline $7 \mathrm{H}-3,110$ & 56.60 & 1.076 & $8 \mathrm{H}-3,116$ & 65.92 & 0.863 & $10 x-3,67$ & 76.47 & 0.680 & $12 X-4,9$ & 88.99 & 0.989 \\
\hline $7 \mathrm{H}-3,120$ & 56.70 & 1.123 & $8 \mathrm{H}-4,12$ & 66.38 & 1.222 & $10 x-3,77$ & 76.57 & 0.646 & $12 \times-4,19$ & 89.09 & 0.777 \\
\hline $7 \mathrm{H}-3,130$ & 56.80 & 1.238 & $8 \mathrm{H}-4,22$ & 66.48 & 1.283 & $10 X-3,87$ & 76.67 & 0.615 & $12 X-4,29$ & 89.19 & 0.840 \\
\hline $7 \mathrm{H}-3,140$ & 56.90 & 1.511 & $8 \mathrm{H}-4,33$ & 66.59 & 1.216 & $10 x-3,97$ & 76.77 & 0.633 & $12 X-4,41$ & 89.31 & 1.011 \\
\hline $7 \mathrm{H}-3,7$ & 55.57 & 1.079 & $8 \mathrm{H}-4,44$ & 66.70 & 1.314 & $10 X-3,107$ & 76.87 & 0.617 & $12 X-4,51$ & 89.41 & 1.056 \\
\hline $7 \mathrm{H}-3,17$ & 55.67 & 1.036 & $8 \mathrm{H}-4,52$ & 66.78 & 1.844 & $10 X-3,122$ & 77.02 & 0.679 & $12 X-4,61$ & 89.51 & 1.010 \\
\hline $7 \mathrm{H}-4,7$ & 57.07 & 1.029 & $8 \mathrm{H}-4,58$ & 66.84 & 1.266 & $10 X-4,10$ & 77.40 & 0.629 & $14 X-1,11$ & 102.41 & 0.886 \\
\hline $7 \mathrm{H}-4,17$ & 57.17 & 1.195 & $8 \mathrm{H}-4,68$ & 66.94 & 1.002 & $10 x-4,20$ & 77.50 & 1.075 & $14 X-1,21$ & 102.51 & 0.575 \\
\hline $7 \mathrm{H}-4,27$ & 57.27 & 1.246 & $8 \mathrm{H}-4,81$ & 67.07 & 1.432 & $10 x-4,30$ & 77.60 & 0.640 & $14 X-1,31$ & 102.61 & 0.850 \\
\hline $7 \mathrm{H}-4,37$ & 57.37 & 1.101 & $8 \mathrm{H}-4,98$ & 67.24 & 1.116 & $10 \times-4,40$ & 77.70 & 0.695 & $14 X-1,38$ & 102.68 & 0.763 \\
\hline $7 \mathrm{H}-4,47$ & 57.47 & 1.020 & $8 \mathrm{H}-4,108$ & 67.34 & 1.253 & $10 X-4,50$ & 77.80 & 1.116 & $14 X-1,48$ & 102.78 & 0.812 \\
\hline $7 \mathrm{H}-4,57$ & 57.57 & 0.991 & $8 \mathrm{H}-4,121$ & 67.47 & 1.211 & $10 x-4,60$ & 77.90 & 1.225 & $14 X-1,62$ & 102.92 & 0.743 \\
\hline $7 \mathrm{H}-4,67$ & 57.67 & 1.155 & $8 \mathrm{H}-4,134$ & 67.60 & 1.327 & $10 x-4,70$ & 78.00 & 0.961 & $14 X-1,72$ & 103.02 & 0.653 \\
\hline $7 \mathrm{H}-4,77$ & 57.77 & 0.910 & $8 \mathrm{H}-6,12$ & 69.38 & 1.086 & $10 X-4,80$ & 78.10 & 0.691 & $14 X-1,103$ & 103.33 & 0.835 \\
\hline $7 \mathrm{H}-4,87$ & 57.87 & 1.121 & $8 \mathrm{H}-6,32$ & 69.58 & 0.886 & $10 x-4,90$ & 78.20 & 0.830 & $14 X-1,130$ & 103.60 & 0.585 \\
\hline $7 \mathrm{H}-4,97$ & 57.97 & 1.000 & $8 \mathrm{H}-6,51$ & 69.77 & 0.963 & $10 X-4,100$ & 78.30 & 0.714 & $14 X-2,15$ & 103.95 & 0.715 \\
\hline 7H-4, 107 & 58.07 & 0.882 & $8 \mathrm{H}-6,74$ & 70.00 & 1.191 & $10 X-4,110$ & 78.40 & 0.800 & $14 X-2,30$ & 104.10 & 0.882 \\
\hline 7H-4, 114 & 58.14 & 12.928 & $8 \mathrm{H}-6,89$ & 70.15 & 1.157 & $10 X-4,120$ & 78.50 & 0.774 & $14 X-2,50$ & 104.30 & 0.717 \\
\hline 7H-4, 121 & 58.21 & 1.029 & $8 \mathrm{H}-7,8$ & 70.34 & 1.191 & $10 X-4,137$ & 78.67 & 0.830 & $14 X-2,79$ & 104.59 & 0.977 \\
\hline 7H-4, 136 & 58.36 & 1.314 & $8 \mathrm{H}-7,30$ & 70.56 & 0.908 & $10 X-4,147$ & 78.77 & 1.007 & $14 X-2,95$ & 104.75 & 0.966 \\
\hline 7H-4, 146 & 58.46 & 1.201 & $8 \mathrm{H}-7,51$ & 70.77 & 0.857 & $10 X-6,10$ & 80.20 & 0.817 & $14 X-2,118$ & 104.98 & 0.908 \\
\hline 7H-5, 9 & 58.59 & 1.032 & $8 \mathrm{H}-7,76$ & 71.02 & 0.800 & $10 X-6,20$ & 80.30 & 0.747 & $14 X-3,15$ & 105.45 & 0.604 \\
\hline 7H-5, 19 & 58.69 & 1.105 & $8 \mathrm{H}-7,95$ & 71.21 & 0.778 & $10 x-6,30$ & 80.40 & 0.760 & $14 X-3,32$ & 105.62 & 0.765 \\
\hline $7 \mathrm{H}-5,32$ & 58.82 & 1.050 & $9 X-1,3$ & 71.53 & 0.717 & $10 X-6,40$ & 80.50 & 0.755 & $14 X-3,50$ & 105.80 & 0.703 \\
\hline $7 \mathrm{H}-5,46$ & 58.96 & 1.154 & $9 X-1,15$ & 71.65 & 0.630 & $10 X-6,50$ & 80.60 & 0.874 & $14 X-3,72$ & 106.02 & 0.706 \\
\hline 7H-5, 56 & 59.06 & 1.087 & $9 X-1,40$ & 71.90 & 0.662 & $10 X-6,60$ & 80.70 & 0.745 & $14 X-3,91$ & 106.21 & 0.801 \\
\hline $7 \mathrm{H}-5,66$ & 59.16 & 1.121 & $9 X-1,50$ & 72.00 & 0.686 & $10 X-6,68$ & 80.78 & 0.763 & $14 X-3,120$ & 106.50 & 0.829 \\
\hline $7 \mathrm{H}-5,76$ & 59.26 & 1.108 & $9 x-1,60$ & 72.10 & 0.659 & $10 \times-6,79$ & 80.89 & 0.910 & $14 X-3,130$ & 106.60 & 1.067 \\
\hline $7 \mathrm{H}-5,88$ & 59.38 & 1.184 & $9 X-1,70$ & 72.20 & 0.693 & $10 \times-6,89$ & 80.99 & 0.940 & $14 X-3,137$ & 106.67 & 0.736 \\
\hline 7H-5, 100 & 59.50 & 0.996 & $9 X-1,80$ & 72.30 & 0.757 & $10 \times-6,99$ & 81.09 & 0.824 & $14 X-4,19$ & 106.99 & 0.773 \\
\hline 7H-5, 115 & 59.65 & 0.944 & $9 X-1,90$ & 72.40 & 0.774 & $10 X-6,110$ & 81.20 & 0.831 & $14 X-4,39$ & 107.19 & 0.932 \\
\hline 7H-5, 123 & 59.73 & 1.091 & $9 X-1,100$ & 72.50 & 0.694 & 10X-6, 119 & 81.29 & 0.986 & $14 X-4,58$ & 107.38 & 1.068 \\
\hline 7H-7, 6 & 61.32 & 1.022 & $9 X-1,110$ & 72.60 & 0.674 & 10X-6, 131 & 81.41 & 3.041 & $14 X-4,86$ & 107.66 & 0.935 \\
\hline 7H-7, 16 & 61.42 & 1.217 & $9 X-1,120$ & 72.70 & 0.792 & $10 \mathrm{X}-6,142$ & 81.52 & 0.911 & $14 X-4,109$ & 107.89 & 0.860 \\
\hline $7 \mathrm{H}-7,26$ & 61.52 & 1.052 & $9 X-1,130$ & 72.80 & 0.734 & $10 X-7,6$ & 81.66 & 0.979 & $14 X-4,114$ & 107.94 & 0.963 \\
\hline 7H-7, 36 & 61.62 & 1.125 & $10 x-1,13$ & 72.93 & 0.672 & $10 X-7,14$ & 81.74 & 0.938 & $14 X-4,134$ & 108.14 & 0.767 \\
\hline 7H-7, 53 & 61.79 & 0.965 & $10 X-1,25$ & 73.05 & 0.695 & $10 X-7,20$ & 81.80 & 0.985 & $14 X-5,10$ & 108.40 & 0.795 \\
\hline 7H-7, 63 & 61.89 & 0.969 & $10 X-1,41$ & 73.21 & 0.639 & $12 X-1,34$ & 84.74 & 0.683 & $14 X-5,20$ & 108.50 & 0.717 \\
\hline 7H-7, 71 & 61.97 & 0.914 & $10 X-1,51$ & 73.31 & 0.930 & $12 X-1,44$ & 84.84 & 1.010 & $14 X-5,27$ & 108.57 & 1.352 \\
\hline $8 \mathrm{H}-1,6$ & 62.06 & 0.918 & $10 X-1,61$ & 73.41 & 0.750 & $12 X-1,54$ & 84.94 & 0.741 & $14 X-5,30$ & 108.60 & 0.701 \\
\hline $8 \mathrm{H}-1,12$ & 62.12 & 0.836 & $10 x-1,73$ & 73.53 & 0.684 & $12 X-1,64$ & 85.04 & 0.807 & $14 X-5,34$ & 108.64 & 0.926 \\
\hline $8 \mathrm{H}-1,25$ & 62.25 & 2.514 & $10 X-1,83$ & 73.63 & 0.751 & $12 X-1,70$ & 85.10 & 0.991 & $14 X-5,35$ & 108.65 & 0.762 \\
\hline $8 \mathrm{H}-1,35$ & 62.35 & 1.064 & $10 x-1,93$ & 73.73 & 0.706 & $12 X-1,80$ & 85.20 & 0.895 & $14 X-5,37$ & 108.67 & 1.183 \\
\hline $8 \mathrm{H}-1,50$ & 62.50 & 1.525 & $10 X-1,103$ & 73.83 & 0.715 & $12 X-1,90$ & 85.30 & 0.802 & $14 X-5,40$ & 108.70 & 0.794 \\
\hline $8 \mathrm{H}-1,60$ & 62.60 & 0.865 & $10 X-1,113$ & 73.93 & 0.772 & $12 X-1,100$ & 85.40 & 0.928 & $14 X-6,35$ & 109.98 & 0.714 \\
\hline $8 \mathrm{H}-1,70$ & 62.70 & 0.920 & $10 X-1,123$ & 74.03 & 0.733 & $12 X-1,110$ & 85.50 & 0.894 & $14 X-6,40$ & 110.03 & 0.725 \\
\hline $8 \mathrm{H}-1,82$ & 62.82 & 1.730 & $10 X-1,133$ & 74.13 & 0.883 & $12 X-1,120$ & 85.60 & 0.869 & $14 X-6,46$ & 110.09 & 0.981 \\
\hline $8 \mathrm{H}-1,87$ & 62.87 & 0.843 & $10 X-1,144$ & 74.24 & 0.915 & $12 X-1,130$ & 85.70 & 0.844 & $14 X-6,50$ & 110.13 & 0.759 \\
\hline $8 \mathrm{H}-1,103$ & 63.03 & 0.805 & $10 x-2,6$ & 74.36 & 0.842 & $12 X-1,141$ & 85.81 & 1.011 & $14 X-6,55$ & 110.18 & 0.921 \\
\hline $8 \mathrm{H}-1,111$ & 63.11 & 0.822 & $10 \times-2,16$ & 74.46 & 0.775 & $12 X-2,7$ & 85.97 & 0.880 & $15 X-1,7$ & 111.77 & 0.689 \\
\hline $8 \mathrm{H}-1,122$ & 63.22 & 0.912 & $10 x-2,26$ & 74.56 & 0.644 & $12 X-2,17$ & 86.07 & 0.849 & $15 X-1,27$ & 111.97 & 0.695 \\
\hline $8 \mathrm{H}-2,8$ & 63.34 & 1.145 & $10 x-2,36$ & 74.66 & 0.690 & $12 X-2,27$ & 86.17 & 0.839 & $15 X-1,47$ & 112.17 & 0.735 \\
\hline $8 \mathrm{H}-2,18$ & 63.44 & 0.947 & $10 \times-2,46$ & 74.76 & 0.684 & $12 X-2,37$ & 86.27 & 0.907 & $15 X-1,67$ & 112.37 & 0.807 \\
\hline $8 \mathrm{H}-2,28$ & 63.54 & 0.960 & $10 x-2,56$ & 74.86 & 0.699 & $12 X-2,46$ & 86.36 & 1.088 & $15 X-1,87$ & 112.57 & 0.753 \\
\hline $8 \mathrm{H}-2,43$ & 63.69 & 1.064 & $10 x-2,66$ & 74.96 & 0.649 & $12 X-3,10$ & 87.50 & 0.967 & $15 X-1,107$ & 112.77 & 0.853 \\
\hline $8 \mathrm{H}-2,53$ & 63.79 & 1.011 & $10 x-2,76$ & 75.06 & 0.750 & $12 X-3,20$ & 87.60 & 0.879 & $15 X-1,127$ & 112.97 & 0.691 \\
\hline $8 \mathrm{H}-2,64$ & 63.90 & 1.079 & $10 X-2,86$ & 75.16 & 0.677 & $12 X-3,30$ & 87.70 & 0.963 & $15 X-1,137$ & 113.07 & 0.811 \\
\hline $8 \mathrm{H}-2,74$ & 64.00 & 0.907 & $10 x-2,96$ & 75.26 & 0.679 & $12 X-3,40$ & 87.80 & 0.857 & $15 X-1,140$ & 113.10 & 0.781 \\
\hline $8 \mathrm{H}-2,87$ & 64.13 & 0.909 & $10 X-2,106$ & 75.36 & 0.685 & $12 X-3,50$ & 87.90 & 0.952 & $15 X-2,1$ & 113.21 & 1.078 \\
\hline $8 \mathrm{H}-2,101$ & 64.27 & 0.790 & $10 X-2,116$ & 75.46 & 0.736 & $12 x-3,60$ & 88.00 & 0.915 & $15 X-2,4$ & 113.24 & 0.894 \\
\hline $8 \mathrm{H}-2,114$ & 64.40 & 0.859 & $10 X-2,126$ & 75.56 & 0.591 & $12 x-3,70$ & 88.10 & 0.859 & $15 X-2,10$ & 113.30 & 0.866 \\
\hline $8 \mathrm{H}-3,7$ & 64.83 & 0.750 & $10 x-2,136$ & 75.66 & 0.582 & $12 X-3,80$ & 88.20 & 0.914 & $15 X-2,20$ & 113.40 & 0.841 \\
\hline $8 \mathrm{H}-3,21$ & 64.97 & 0.856 & $10 X-2,146$ & 75.76 & 0.706 & $12 X-3,84$ & 88.24 & 0.945 & $15 X-2,30$ & 113.50 & 0.910 \\
\hline $8 \mathrm{H}-3,31$ & 65.07 & 0.849 & $10 x-3,7$ & 75.87 & 0.611 & $12 X-3,94$ & 88.34 & 0.984 & $15 X-2,40$ & 113.60 & 0.795 \\
\hline
\end{tabular}


Table T13 (continued).

\begin{tabular}{|c|c|c|c|c|c|c|c|c|c|c|c|}
\hline $\begin{array}{l}\text { Core, section, } \\
\text { interval }(\mathrm{cm})\end{array}$ & $\begin{array}{l}\text { Depth } \\
\text { (mbsf) }\end{array}$ & $\begin{array}{l}\text { Resistivity } \\
(\Omega \mathrm{m})\end{array}$ & $\begin{array}{l}\text { Core, section, } \\
\text { interval }(\mathrm{cm})\end{array}$ & $\begin{array}{l}\text { Depth } \\
\text { (mbsf) }\end{array}$ & $\begin{array}{l}\text { Resistivity } \\
\quad(\Omega \mathrm{m})\end{array}$ & $\begin{array}{l}\text { Core, section, } \\
\text { interval }(\mathrm{cm})\end{array}$ & $\begin{array}{l}\text { Depth } \\
\text { (mbsf) }\end{array}$ & $\begin{array}{l}\text { Resistivity } \\
(\Omega \mathrm{m})\end{array}$ & $\begin{array}{l}\text { Core, section, } \\
\text { interval }(\mathrm{cm})\end{array}$ & $\begin{array}{l}\text { Depth } \\
\text { (mbsf) }\end{array}$ & $\begin{array}{l}\text { Resistivity } \\
(\Omega \mathrm{m})\end{array}$ \\
\hline $15 X-2,50$ & 113.70 & 0.792 & $20 X-1,20$ & 150.40 & 0.634 & $24 X-2,40$ & 180.79 & 1.044 & $6 X-4,14$ & 221.65 & 1.811 \\
\hline $15 X-2,53$ & 113.73 & 0.918 & $20 X-1,33$ & 150.53 & 0.726 & $24 X-2,50$ & 180.89 & 0.909 & $6 X-4,16$ & 221.67 & 0.741 \\
\hline $15 X-2,57$ & 113.77 & 0.817 & $20 X-1,49$ & 150.69 & 0.658 & $24 X-2,57$ & 180.96 & 1.555 & $6 X-4,24$ & 221.75 & 0.962 \\
\hline $15 X-3,25$ & 114.95 & 1.027 & $20 X-1,63$ & 150.83 & 0.837 & $24 X-2,64$ & 181.03 & 1.172 & $6 X-4,34$ & 221.85 & 0.705 \\
\hline $15 X-3,26$ & 114.96 & 1.100 & $20 X-1,81$ & 151.01 & 1.009 & $24 X-2,78$ & 181.17 & 0.942 & $6 X-4,44$ & 221.95 & 1.451 \\
\hline $15 X-3,27$ & 114.97 & 0.961 & $20 X-1,96$ & 151.16 & 0.832 & $24 X-2,84$ & 181.23 & 1.109 & $6 X-4,54$ & 222.05 & 1.144 \\
\hline $15 X-3,28$ & 114.98 & 0.907 & $20 X-1,113$ & 151.33 & 0.822 & $24 X-2,87$ & 181.26 & 0.844 & $6 X-4,74$ & 222.25 & 0.948 \\
\hline $15 X-3,29$ & 114.99 & 1.301 & $20 X-1,131$ & 151.51 & 0.684 & $24 X-2,99$ & 181.38 & 0.848 & $6 X-4,84$ & 222.35 & 1.302 \\
\hline $15 X-3,30$ & 115.00 & 1.107 & $20 X-1,144$ & 151.64 & 0.618 & $24 X-2,109$ & 181.48 & 0.908 & $6 X-4,94$ & 222.45 & 0.788 \\
\hline $15 X-3,31$ & 115.01 & 1.347 & $20 X-2,20$ & 151.90 & 0.621 & $24 X-2,125$ & 181.64 & 1.250 & $6 X-4,104$ & 222.55 & 1.048 \\
\hline $15 X-3,32$ & 115.02 & 1.456 & $20 x-2,32$ & 152.02 & 0.913 & $24 X-4,25$ & 183.52 & 0.914 & $7 X-2,57$ & 229.27 & 0.847 \\
\hline $15 X-3,33$ & 115.03 & 1.374 & $20 \times-2,49$ & 152.19 & 0.884 & $24 X-4,38$ & 183.65 & 0.897 & $7 X-2,81$ & 229.51 & 1.371 \\
\hline $15 X-3,34$ & 115.04 & 0.993 & $20 X-2,77$ & 152.47 & 0.837 & $24 X-4,47$ & 183.74 & 1.155 & $7 X-2,101$ & 229.71 & 1.564 \\
\hline $15 X-3,35$ & 115.05 & 0.727 & $20 X-2,95$ & 152.65 & 0.810 & $24 X-4,57$ & 183.84 & 0.989 & $7 X-2,121$ & 229.91 & 1.333 \\
\hline $15 X-3,36$ & 115.06 & 0.822 & $20 X-2,114$ & 152.84 & 0.660 & $24 X-4,67$ & 183.94 & 0.996 & $7 X-2,143$ & 230.13 & 1.249 \\
\hline $15 X-3,37$ & 115.07 & 0.862 & $20 X-2,136$ & 153.06 & 0.986 & $24 X-4,77$ & 184.04 & 1.023 & $7 X-3,10$ & 230.30 & 1.085 \\
\hline $15 X-3,40$ & 115.10 & 0.760 & $20 X-3,7$ & 153.27 & 1.866 & $24 X-4,87$ & 184.14 & 1.110 & $7 X-3,30$ & 230.50 & 0.988 \\
\hline $15 X-3,45$ & 115.15 & 0.964 & $20 X-3,20$ & 153.40 & 1.379 & $24 X-5,6$ & 184.33 & 0.990 & $7 X-3,20$ & 230.40 & 0.942 \\
\hline $15 X-3,50$ & 115.20 & 0.840 & $20 X-3,29$ & 153.49 & 1.041 & $24 X-5,16$ & 184.43 & 0.975 & $7 X-3,40$ & 230.60 & 0.739 \\
\hline $15 X-3,55$ & 115.25 & 0.854 & $20 x-3,35$ & 153.55 & 1.044 & $24 X-5,26$ & 184.53 & 0.748 & $7 X-3,60$ & 230.80 & 0.684 \\
\hline $15 X-3,60$ & 115.30 & 0.812 & $20 X-4,10$ & 153.94 & 0.998 & $24 X-5,36$ & 184.63 & 0.849 & $7 X-3,78$ & 230.98 & 1.007 \\
\hline $15 X-3,65$ & 115.35 & 1.139 & $20 X-4,29$ & 154.13 & 0.875 & $24 X-5,56$ & 184.83 & 0.888 & $7 X-3,93$ & 231.13 & 0.994 \\
\hline $16 X-1,13$ & 121.43 & 0.632 & $20 X-4,43$ & 154.27 & 0.791 & $24 X-5,66$ & 184.93 & 0.834 & $7 X-4,15$ & 231.35 & 0.769 \\
\hline $16 X-1,20$ & 121.50 & 0.613 & $20 X-4,56$ & 154.40 & 0.970 & $24 X-5,76$ & 185.03 & 0.904 & $7 X-4,30$ & 231.50 & 0.807 \\
\hline $16 X-1,24$ & 121.54 & 0.663 & $20 X-4,74$ & 154.58 & 0.731 & $24 X-5,86$ & 185.13 & 1.088 & $7 X-4,40$ & 231.60 & 0.837 \\
\hline $16 X-1,49$ & 121.79 & 0.652 & $20 X-4,85$ & 154.69 & 0.739 & $24 X-5,96$ & 185.23 & 1.034 & $7 X-4,60$ & 231.80 & 0.765 \\
\hline $16 X-1,74$ & 122.04 & 0.635 & $20 X-4,95$ & 154.79 & 1.212 & $24 X-5,103$ & 185.30 & 1.844 & $7 X-5,9$ & 232.08 & 1.692 \\
\hline $16 X-1,87$ & 122.17 & 0.652 & $20 X-4,105$ & 154.89 & 0.718 & $25 X-1,8$ & 188.88 & 0.669 & $7 X-5,29$ & 232.28 & 0.765 \\
\hline $16 X-1,117$ & 122.47 & 0.665 & $20 X-4,110$ & 154.94 & 1.132 & $25 X-1,22$ & 189.02 & 0.920 & $7 X-5,33$ & 232.32 & 1.509 \\
\hline $16 X-2,19$ & 122.99 & 1.005 & $20 X-4,115$ & 154.99 & 0.718 & $25 X-1,35$ & 189.15 & 1.041 & $7 X-5,53$ & 232.52 & 0.895 \\
\hline $16 X-2,44$ & 123.24 & 0.845 & $20 X-4,122$ & 155.06 & 1.116 & & & & $7 X-5,62$ & 232.61 & 1.035 \\
\hline $16 X-2,82$ & 123.62 & 0.714 & $20 X-4,129$ & 155.13 & 0.989 & $1 X-2,20$ & & & $7 X-6,10$ & 232.77 & 0.865 \\
\hline 16X-2, 101 & 123.81 & 0.753 & $20 X-4,141$ & 155.25 & 0.848 & $1 X-2,30$ & 190.60 & 0.825 & $7 X-6,30$ & 232.97 & 1.278 \\
\hline $16 X-6,3$ & 126.68 & 0.819 & $20 X-6,12$ & 156.96 & 0.961 & $1 X-2,40$ & 190.70 & 0.834 & $7 X-6,60$ & 233.27 & 0.864 \\
\hline $16 X-6,17$ & 126.82 & 0.718 & $20 X-6,18$ & 157.02 & 0.757 & $1 X-2,50$ & 190.80 & 0.904 & $7 X-6,76$ & 233.43 & 1.326 \\
\hline $16 X-6,24$ & 126.89 & 0.981 & $20 X-6,25$ & 157.09 & 0.783 & & 190.89 & 0.913 & $7 X-6,83$ & 233.50 & 1.991 \\
\hline $16 X-6,34$ & 126.99 & 1.304 & $20 X-6,42$ & 157.26 & 0.742 & $\begin{array}{l}1 X-2,39 \\
1 X-2,63\end{array}$ & 190.93 & 0.953 & $7 X-6,123$ & 233.90 & 1.824 \\
\hline $16 X-6,65$ & 127.30 & 1.270 & $20 X-6,56$ & 157.40 & 0.731 & $1 X-2,70$ & 191.00 & 0.814 & $7 X-6,132$ & 233.99 & 2.936 \\
\hline $16 X-6,90$ & 127.55 & 1.266 & $20 X-6,67$ & 157.51 & 0.819 & & 191.07 & 0.730 & $7 X-6,143$ & 234.10 & 2.024 \\
\hline $16 X-6,99$ & 127.64 & 1.297 & $20 X-6,75$ & 157.59 & 1.335 & $1 X-2,85$ & 191.15 & 0.696 & $7 X-7,2$ & 234.19 & 1.341 \\
\hline $18 X-1,22$ & 131.12 & 0.800 & $20 X-6,90$ & 157.74 & 0.904 & $1 \mathrm{X}-2,95$ & 191.25 & 0.962 & $7 X-7,22$ & 234.39 & 1.578 \\
\hline $18 X-1,59$ & 131.49 & 0.834 & $20 X-6,103$ & 157.87 & 1.207 & $\begin{array}{l}1 \lambda-2, \\
1 X-2,105\end{array}$ & 191.35 & 0.972 & $7 X-7,35$ & 234.52 & 0.981 \\
\hline $18 X-1,73$ & 131.63 & 0.709 & $20 X-6,114$ & 157.98 & 1.278 & & 191.45 & 0.899 & $7 X-7,50$ & 234.67 & 0.899 \\
\hline $18 X-1,93$ & 131.83 & 0.911 & $21 X-1,8$ & 159.88 & 0.947 & $1 X-2,128$ & 191.58 & 1.026 & $8 X-1,17$ & 236.97 & 0.688 \\
\hline $18 X-1,126$ & 132.16 & 0.841 & $21 X-1,18$ & 159.98 & 0.844 & $2 X-1,1$ & 198.41 & 1.146 & $8 X-3,87$ & 240.02 & 0.998 \\
\hline $18 X-2,10$ & 132.50 & 0.711 & $21 X-1,26$ & 160.06 & 1.066 & $2 X-1,12$ & 198.52 & $\begin{array}{l}1.140 \\
1.197\end{array}$ & $8 X-3,100$ & 240.15 & 1.257 \\
\hline $18 X-2,20$ & 132.60 & 0.680 & $21 X-3,12$ & 161.93 & 0.758 & $2 X-1,22$ & 198.62 & 1.257 & $8 X-5,10$ & 241.90 & 1.334 \\
\hline $18 X-2,30$ & 132.70 & 0.663 & $21 X-3,22$ & 162.03 & 0.878 & $\begin{array}{l}2 \lambda-1,22 \\
3 X-1,4\end{array}$ & 203.24 & 0.974 & $8 X-5,29$ & 242.09 & 1.136 \\
\hline $19 X-1,42$ & 140.92 & 0.789 & $21 X-3,37$ & 162.18 & 0.843 & $\begin{array}{l}3 \lambda-1,4 \\
3 X-1,7\end{array}$ & 203.27 & 0.790 & $8 X-5,44$ & 242.24 & 1.110 \\
\hline $19 X-1,57$ & 141.07 & 0.840 & $23 X-1,7$ & 170.47 & 1.175 & $4 X-2,13$ & 209.37 & 0.932 & $8 X-5,64$ & 242.44 & 0.889 \\
\hline $19 X-1,74$ & 141.24 & 0.770 & $23 X-1,14$ & 170.54 & 1.119 & $4 X-2,45$ & 209.69 & 0.700 & $8 X-5,76$ & 242.56 & 1.356 \\
\hline $19 X-1,89$ & 141.39 & 0.635 & $23 X-1,20$ & 170.60 & 1.153 & $x-2,55$ & 209.79 & 0.740 & $8 X-5,82$ & 242.62 & 1.032 \\
\hline 19X-1, 107 & 141.57 & 0.961 & $23 X-1,25$ & 170.65 & 1.097 & $\begin{array}{l}4 X-2,55 \\
4 X-2,65\end{array}$ & 209.89 & 0.678 & $8 X-5,109$ & 242.89 & 1.092 \\
\hline $19 X-1,125$ & 141.75 & 1.028 & $23 X-1,28$ & 170.68 & 0.793 & $\begin{array}{l}4 \lambda-2,05 \\
4 X-2,75\end{array}$ & 209.99 & 1.001 & $8 X-5,128$ & 243.08 & 1.697 \\
\hline $19 X-1,138$ & 141.88 & 0.885 & $23 X-1,34$ & 170.74 & 0.748 & $4 X-2,83$ & 210.07 & 0.684 & $8 X-5,144$ & 243.24 & 1.237 \\
\hline $19 X-2,11$ & 142.11 & 0.805 & $23 X-1,42$ & 170.82 & 0.760 & $4 X-4,10$ & 211.02 & 0.807 & $8 X-6,12$ & 243.42 & 1.081 \\
\hline $19 X-2,29$ & 142.29 & 0.799 & $23 X-1,48$ & 170.88 & 0.808 & $4 X-4,45$ & 211.37 & $\begin{array}{l}0.807 \\
1.195\end{array}$ & $8 X-6,37$ & 243.67 & 2.111 \\
\hline $19 X-2,44$ & 142.44 & 0.515 & $24 X-1,27$ & 179.27 & 0.956 & & 211.59 & $\begin{array}{l}1.195 \\
1.022\end{array}$ & $8 X-6,64$ & 243.94 & 1.318 \\
\hline $19 X-2,61$ & 142.61 & 0.779 & $24 X-1,42$ & 179.42 & 1.492 & $4 X-4,80$ & 211.72 & 1.055 & $8 X-7,12$ & 244.92 & 1.099 \\
\hline $19 X-2,81$ & 142.81 & 0.677 & $24 X-1,63$ & 179.63 & 1.211 & $6 X-3,14$ & 220.53 & 0.749 & $8 X-7,32$ & 245.12 & 1.541 \\
\hline 19X-2, 101 & 143.01 & 0.682 & $24 X-1,77$ & 179.77 & 1.058 & $6 X-3,24$ & 220.63 & 0.812 & $8 X-7,45$ & 245.25 & 1.322 \\
\hline 19X-2, 119 & 143.19 & 0.912 & $24 X-1,84$ & 179.84 & 0.910 & $\begin{array}{l}0 \lambda-3,24 \\
6 X-3,34\end{array}$ & 220.73 & 0.656 & $8 X-7,59$ & 245.39 & 1.441 \\
\hline $19 X-2,138$ & 143.38 & 1.809 & $24 X-1,90$ & 179.90 & 0.865 & $\begin{array}{l}0 \times-3,34 \\
6 X-3,44\end{array}$ & 220.83 & 0.648 & $9 X-1,27$ & 246.77 & 1.038 \\
\hline $19 X-2,144$ & 143.44 & 0.999 & $24 X-1,94$ & 179.94 & 0.907 & $6 X-3,54$ & 220.93 & 0.817 & $9 X-1,44$ & 246.94 & 0.900 \\
\hline $19 X-3,8$ & 143.58 & 1.382 & $24 X-1,100$ & 180.00 & 0.811 & & 221.06 & 0.663 & $9 X-1,73$ & 247.23 & 0.924 \\
\hline $19 X-3,15$ & 143.65 & 0.704 & $24 X-1,114$ & 180.14 & 0.969 & $\begin{array}{l}0 x-3,07 \\
6 X-3,77\end{array}$ & 221.16 & $\begin{array}{l}0.063 \\
0.834\end{array}$ & $9 X-1,91$ & 247.41 & 1.071 \\
\hline $19 X-5,16$ & 145.46 & 0.845 & $24 X-1,129$ & 180.29 & 1.008 & $6 X-4,9$ & 221.60 & 1.466 & $9 X-1,103$ & 247.53 & 0.993 \\
\hline $19 X-5,22$ & 145.52 & 0.620 & $24 X-2,19$ & 180.58 & 0.863 & $6 X-4,9$ & 221.60 & 1.687 & $9 X-1,113$ & 247.63 & 0.792 \\
\hline $19 X-5,28$ & 145.58 & 0.598 & $24 X-2,30$ & 180.69 & 0.809 & $\begin{array}{l}6 x-4,9 \\
6 X-4,10\end{array}$ & 221.61 & $\begin{array}{l}1.687 \\
1.047\end{array}$ & $9 X-1,144$ & 247.94 & 0.835 \\
\hline
\end{tabular}


Table T13 (continued).

\begin{tabular}{|c|c|c|c|c|c|}
\hline $\begin{array}{l}\text { Core, section, } \\
\text { interval }(\mathrm{cm})\end{array}$ & $\begin{array}{l}\text { Depth } \\
\text { (mbsf) }\end{array}$ & $\begin{array}{l}\text { Resistivity } \\
(\Omega \mathrm{m})\end{array}$ & $\begin{array}{l}\text { Core, section, } \\
\text { interval }(\mathrm{cm})\end{array}$ & $\begin{array}{l}\text { Depth } \\
\text { (mbsf) }\end{array}$ & $\begin{array}{c}\text { Resistivity } \\
(\Omega \mathrm{m})\end{array}$ \\
\hline $9 X-2,25$ & 248.25 & 1.089 & $11 X-5,131$ & 264.41 & 1.328 \\
\hline $9 X-2,56$ & 248.56 & 0.726 & $11 X-6,13$ & 264.73 & 0.994 \\
\hline $9 X-2,76$ & 248.76 & 0.854 & $11 X-6,22$ & 264.82 & 0.965 \\
\hline $9 X-2,91$ & 248.91 & 0.678 & $11 X-6,32$ & 264.92 & 0.939 \\
\hline $9 X-4,12$ & 251.12 & 0.813 & $11 X-6,46$ & 265.06 & 0.863 \\
\hline $9 X-4,31$ & 251.31 & 0.728 & $11 X-6,8$ & 264.68 & 0.726 \\
\hline $9 X-4,51$ & 251.51 & 0.916 & $12 X-1,18$ & 265.98 & 0.730 \\
\hline $9 X-4,67$ & 251.67 & 0.784 & $12 X-1,18$ & 265.98 & 0.774 \\
\hline $9 X-4,87$ & 251.87 & 0.886 & $12 X-1,31$ & 266.11 & 0.872 \\
\hline $9 X-4,102$ & 252.02 & 0.876 & $12 \times-1,49$ & 266.29 & 0.883 \\
\hline $9 X-5,6$ & 252.34 & 0.695 & $12 X-1,62$ & 266.42 & 0.896 \\
\hline $9 X-5,34$ & 252.62 & 0.820 & $12 X-1,79$ & 266.59 & 0.904 \\
\hline $9 X-5,51$ & 252.79 & 0.860 & $12 X-1,137$ & 267.17 & 0.646 \\
\hline $9 X-5,73$ & 253.01 & 0.833 & $12 X-3,29$ & 268.96 & 0.859 \\
\hline $9 X-5,92$ & 253.20 & 0.816 & $12 x-3,65$ & 269.32 & 1.025 \\
\hline $9 X-5,101$ & 253.29 & 0.859 & $12 X-3,83$ & 269.50 & 1.493 \\
\hline $9 X-5,129$ & 253.57 & 0.826 & $12 X-3,100$ & 269.67 & 1.229 \\
\hline $9 X-5,146$ & 253.74 & 0.744 & $12 X-4,84$ & 271.01 & 1.080 \\
\hline $9 X-6,8$ & 253.86 & 0.711 & $12 X-4,102$ & 271.19 & 0.825 \\
\hline $9 X-6,19$ & 253.97 & 1.030 & $12 X-4,109$ & 271.26 & 1.314 \\
\hline $9 X-6,34$ & 254.12 & 0.762 & $12 \times-4,119$ & 271.36 & 0.918 \\
\hline $9 X-6,77$ & 253.78 & 0.705 & $12 X-4,138$ & 271.55 & 0.914 \\
\hline $9 X-7,5$ & 254.78 & 0.788 & $12 X-5,16$ & 271.83 & 1.010 \\
\hline $9 X-7,18$ & 254.96 & 1.010 & $12 X-5,40$ & 272.07 & 0.892 \\
\hline $9 X-7,33$ & 255.11 & 1.425 & $12 X-5,56$ & 272.23 & 1.108 \\
\hline $9 X-7,46$ & 255.24 & 0.859 & $12 X-5,71$ & 272.38 & 1.268 \\
\hline $9 X-7,60$ & 255.30 & 0.877 & $15 X-1,13$ & 294.83 & 0.635 \\
\hline $11 X-1,15$ & 257.10 & 0.716 & $15 X-1,34$ & 295.04 & 1.018 \\
\hline $11 X-1,26$ & 257.36 & 0.860 & $15 X-1,79$ & 295.49 & 0.652 \\
\hline $11 X-1,39$ & 257.49 & 1.049 & $15 X-1,107$ & 295.77 & 0.734 \\
\hline $11 X-1,48$ & 257.50 & 0.763 & $15 X-1,137$ & 296.07 & 0.761 \\
\hline $11 X-1,65$ & 257.75 & 0.828 & $15 X-4,10$ & 298.53 & 1.625 \\
\hline $11 X-1,85$ & 257.95 & 0.557 & $15 X-4,20$ & 298.63 & 1.611 \\
\hline $11 X-1,107$ & 258.17 & 0.947 & $15 X-4,30$ & 298.73 & 2.662 \\
\hline $11 X-1,122$ & 258.32 & 1.167 & $15 X-4,32$ & 298.75 & 2.802 \\
\hline $11 X-2,16$ & 258.76 & 0.937 & & & \\
\hline $11 X-2,36$ & 258.96 & 0.818 & $8 X-1,33$ & 237.13 & 0.826 \\
\hline $11 X-2,54$ & 259.14 & 0.813 & $\begin{array}{l}8 X-1,33 \\
8 X-1,84\end{array}$ & 237.64 & 0.221 \\
\hline $11 X-2,87$ & 258.60 & 0.897 & $8 X-1,111$ & 237.91 & 0.359 \\
\hline $11 X-3,10$ & 260.10 & 0.879 & $8 X-1,131$ & 238.11 & 0.318 \\
\hline $11 X-3,20$ & 260.30 & 0.825 & $8 X-1,139$ & 238.19 & 2.201 \\
\hline $11 X-3,40$ & 260.50 & 0.840 & $8 X-1,97$ & 237.77 & 1.093 \\
\hline $11 X-3,53$ & 260.63 & 1.270 & $8 X-1,84$ & 237.64 & 1.008 \\
\hline $11 X-3,63$ & 260.73 & 1.335 & $8 X-1,69$ & 237.49 & 0.960 \\
\hline $11 X-3,74$ & 260.84 & 0.856 & $8 X-1,51$ & 237.31 & 1.061 \\
\hline $11 \mathrm{X}-3,92$ & 261.02 & 0.908 & $8 X-1,25$ & 237.05 & 0.814 \\
\hline $11 X-3,106$ & 261.16 & 1.056 & $8 X-2,6$ & 238.36 & 1.171 \\
\hline $11 X-3,120$ & 261.30 & 0.928 & $8 X-2,24$ & 238.54 & 1.037 \\
\hline $11 X-3,135$ & 261.45 & $\begin{array}{l}1.054 \\
1373\end{array}$ & $8 X-2,40$ & 238.70 & 1.134 \\
\hline $11 X-5,53$ & 263.10 & $\begin{array}{l}1.373 \\
0.924\end{array}$ & $8 X-2,58$ & 238.88 & 1.182 \\
\hline $11 X-5,74$ & 263.84 & 0.924 & $8 X-3,65$ & 239.80 & 1.359 \\
\hline $11 X-5,84$ & 263.94 & 0.857 & $8 X-3,74$ & 239.89 & 1.218 \\
\hline $\begin{array}{l}11 X-5,99 \\
11 X-5,114\end{array}$ & $\begin{array}{l}264.09 \\
264.24\end{array}$ & $\begin{array}{l}1.086 \\
0.965\end{array}$ & & & \\
\hline
\end{tabular}


Table T14. Thermal conductivity, Holes U1325B and U1325C.

\begin{tabular}{|c|c|c|c|c|c|}
\hline \multirow{2}{*}{$\begin{array}{l}\text { Core, section, } \\
\text { interval }(\mathrm{cm})\end{array}$} & \multirow{2}{*}{$\begin{array}{l}\text { Depth } \\
\text { (mbsf) }\end{array}$} & \multicolumn{4}{|c|}{ Thermal conductivity $(\mathrm{W} /[\mathrm{m} \cdot \mathrm{K}])$} \\
\hline & & Average & 1 & 2 & 3 \\
\hline \multicolumn{6}{|l|}{ 311-U1325B- } \\
\hline $1 \mathrm{H}-2,33$ & 1.83 & 0.939 & 0.940 & 0.939 & 0.937 \\
\hline $2 \mathrm{H}-5,76$ & 16.06 & 0.981 & 0.979 & 0.983 & 0.982 \\
\hline $3 X-1,38$ & 19.18 & 1.289 & 1.280 & 1.287 & 1.301 \\
\hline $4 \mathrm{H}-2,89$ & 26.21 & 0.943 & 0.939 & 0.944 & 0.945 \\
\hline $4 \mathrm{H}-4,111$ & 29.43 & 0.871 & 0.869 & 0.871 & 0.872 \\
\hline $4 \mathrm{H}-6,60$ & 31.92 & 0.979 & 0.984 & 0.974 & 0.979 \\
\hline $5 \mathrm{H}-1,41$ & 33.91 & 1.035 & 1.037 & 1.034 & 1.035 \\
\hline $5 \mathrm{H}-4,91$ & 38.83 & 0.857 & 0.862 & 0.853 & 0.856 \\
\hline $5 H-6,86$ & 41.78 & 0.763 & 0.758 & 0.756 & 0.775 \\
\hline $6 \mathrm{H}-2,81$ & 45.31 & 1.165 & 1.166 & 1.164 & 1.165 \\
\hline $6 \mathrm{H}-4,82$ & 48.32 & 1.126 & 1.122 & 1.128 & 1.127 \\
\hline $6 \mathrm{H}-6,29$ & 50.79 & 1.121 & 1.126 & 1.116 & 1.120 \\
\hline $7 \mathrm{H}-2,35$ & 54.35 & 1.148 & 1.161 & 1.121 & 1.163 \\
\hline $7 \mathrm{H}-4,77$ & 57.77 & 1.153 & 1.165 & 1.145 & 1.149 \\
\hline 7H-6, 69 & 60.69 & 1.173 & 1.167 & 1.163 & 1.190 \\
\hline $8 \mathrm{H}-2,29$ & 63.55 & 1.264 & 1.203 & 1.274 & 1.316 \\
\hline $8 \mathrm{H}-4,75$ & 67.01 & 1.130 & 1.138 & 1.128 & 1.125 \\
\hline $8 \mathrm{H}-6,69$ & 69.95 & 1.205 & 1.205 & 1.204 & 1.206 \\
\hline $9 X-1,61$ & 72.11 & 1.155 & 1.155 & 1.154 & 1.157 \\
\hline 10X-2, 101 & 75.31 & 0.872 & 0.873 & 0.872 & 0.872 \\
\hline $10 X-4,114$ & 78.44 & 1.056 & 1.068 & 1.050 & 1.051 \\
\hline $10 X-6,100$ & 81.10 & 0.782 & 0.785 & 0.778 & 1.000 \\
\hline $13 \mathrm{X}-1,38$ & 93.28 & 1.124 & 1.140 & 1.116 & 1.116 \\
\hline $14 X-1,80$ & 103.10 & 1.016 & 1.017 & 1.013 & 1.018 \\
\hline $14 X-3,12$ & 105.42 & 0.927 & 0.932 & 0.926 & 0.923 \\
\hline $15 X-1,54$ & 112.24 & 1.027 & 1.026 & 1.026 & 1.030 \\
\hline $15 X-3,9.5$ & 114.795 & 1.229 & 1.232 & 1.226 & 1.228 \\
\hline $16 X-2,64$ & 123.44 & 1.040 & 1.034 & 1.036 & 1.050 \\
\hline $16 \mathrm{X}-3,31$ & 124.61 & 1.072 & 1.068 & 1.076 & 1.071 \\
\hline $18 \mathrm{X}-1,41$ & 131.31 & 0.914 & 0.910 & 0.907 & 0.924 \\
\hline $19 \mathrm{X}-1,84.5$ & 141.345 & 1.011 & 1.012 & 1.011 & 1.010 \\
\hline $20 X-6,30$ & 157.14 & 1.114 & 1.121 & 1.106 & 1.000 \\
\hline $23 X-2,36$ & 172.26 & 0.945 & 0.951 & 0.945 & 0.938 \\
\hline $24 \mathrm{X}-1,89$ & 179.89 & 1.252 & 1.245 & 1.252 & 1.258 \\
\hline $24 X-5,42$ & 184.69 & 0.823 & 0.820 & 0.824 & 0.826 \\
\hline $25 \mathrm{X}-1,18$ & 188.98 & 0.836 & 0.836 & 0.836 & 0.835 \\
\hline \multicolumn{6}{|l|}{ 311-U1325C- } \\
\hline $1 X-2,12$ & 190.42 & 0.938 & 0.955 & 0.947 & 0.911 \\
\hline $1 X-2,61$ & 190.91 & 0.945 & 0.961 & 0.935 & 0.938 \\
\hline $4 X-2,37$ & 209.61 & 0.691 & 0.695 & 0.692 & 0.687 \\
\hline $4 X-4,79$ & 211.71 & 0.830 & 0.835 & 0.830 & 0.826 \\
\hline $6 X-3,20$ & 220.59 & 1.169 & 1.164 & 1.169 & 1.174 \\
\hline $7 X-2,102$ & 229.72 & 1.303 & 1.311 & 1.292 & 1.306 \\
\hline $7 X-5,48$ & 232.47 & 1.312 & 1.322 & 1.305 & 1.309 \\
\hline $8 X-2,40$ & 238.70 & 1.096 & 1.104 & 1.086 & 1.099 \\
\hline $8 X-5,55$ & 242.35 & 1.050 & 1.041 & 1.057 & 1.053 \\
\hline $9 X-2,53$ & 248.53 & 1.138 & 1.152 & 1.124 & 1.139 \\
\hline $9 X-4,40$ & 251.40 & 1.187 & 1.196 & 1.191 & 1.173 \\
\hline $9 X-5,76$ & 253.04 & 1.220 & 1.230 & 1.204 & 1.226 \\
\hline $11 \mathrm{X}-1,25$ & 257.35 & 1.093 & 1.094 & 1.095 & 1.090 \\
\hline $11 X-3,110$ & 261.20 & 1.280 & 1.289 & 1.277 & 1.275 \\
\hline $11 X-5,55$ & 263.65 & 1.165 & 1.175 & 1.176 & 1.144 \\
\hline $12 X-1,45$ & 266.25 & 0.872 & 0.858 & 0.878 & 0.880 \\
\hline $12 X-3,78$ & 269.45 & 1.039 & 1.048 & 1.032 & 1.037 \\
\hline $12 X-5,42$ & 272.09 & 0.963 & 0.969 & 0.961 & 0.959 \\
\hline $14 \mathrm{X}-3,19$ & 286.89 & 1.226 & 1.220 & 1.230 & 1.229 \\
\hline $14 \mathrm{X}-3,32$ & 287.02 & 1.243 & 1.263 & 1.226 & 1.239 \\
\hline $15 X-4,17$ & 298.60 & 1.210 & 1.221 & 1.199 & 1.209 \\
\hline $15 X-4,24.5$ & 298.675 & 1.138 & 1.143 & 1.129 & 1.142 \\
\hline
\end{tabular}


Table T15. In situ temperature, Holes U1325B and U1325C.

\begin{tabular}{|c|c|c|c|c|c|c|c|}
\hline \multirow[b]{2}{*}{ Core } & \multirow{2}{*}{$\begin{array}{l}\text { Depth } \\
\text { (mbsf) }\end{array}$} & \multicolumn{2}{|c|}{ Temperature $\left({ }^{\circ} \mathrm{C}\right)$} & \multirow{2}{*}{$\begin{array}{l}\text { Thermal } \\
\text { conductivity } \\
(\mathrm{W} /[\mathrm{m} \cdot \mathrm{K}])\end{array}$} & \multirow{2}{*}{$\begin{array}{c}\text { Calibration } \\
\left.\text { correction ( }{ }^{\circ}\right)\end{array}$} & \multirow{2}{*}{$\begin{array}{l}\text { Temperature } \\
\text { tool }\end{array}$} & \multirow{2}{*}{$\begin{array}{l}\text { Solution } \\
\text { reliability }\end{array}$} \\
\hline & & Corrected & Uncorrected & & & & \\
\hline \multicolumn{8}{|l|}{ 311-U1325B- } \\
\hline $4 \mathrm{H}$ & 33.5 & 4.44 & 4.44 & 1.1 & 0 & APCT-3 & Excellent \\
\hline $6 \mathrm{H}$ & 52.5 & 6.47 & 6.47 & 1.1 & 0 & APCT-3 & Excellent \\
\hline $8 \mathrm{H}$ & 71.5 & 7.11 & 7.11 & 1.1 & 0 & APCT-3 & Excellent \\
\hline $19 \mathrm{H}-20 \mathrm{H}$ & 150.2 & 12.66 & 12.66 & 1.1 & 0 & DVTP & Excellent \\
\hline \multicolumn{8}{|l|}{ 311-U1325C- } \\
\hline $5 \mathrm{H}-6 \mathrm{H}$ & 218.6 & 16.89 & 16.89 & 1.1 & 0 & DVTP & Good \\
\hline $12 \mathrm{H}-13 \mathrm{H}$ & 275.4 & 18.64 & 18.64 & 1.1 & 0 & DVTP & Very good \\
\hline
\end{tabular}

Note: APCT-3 = third-generation advanced piston corer temperature tool, DVTP = Davis-Villinger Temperature Probe.

Table T16. Summary of pressure coring operations at Site U1325.

\begin{tabular}{|c|c|c|c|c|c|c|c|}
\hline \multirow[b]{2}{*}{ Core } & \multirow{2}{*}{$\begin{array}{l}\text { Core-top } \\
\text { depth } \\
\text { (mbsf) }\end{array}$} & \multirow{2}{*}{$\begin{array}{l}\text { Length } \\
\text { recovered* } \\
(\mathrm{cm})\end{array}$} & \multirow{2}{*}{$\begin{array}{l}\text { Length } \\
\text { curated } \\
(\mathrm{cm})\end{array}$} & \multirow{2}{*}{$\begin{array}{l}\text { Pressure at } \\
\text { core depth } \\
(\mathrm{MPa})\end{array}$} & \multicolumn{2}{|c|}{$\begin{array}{c}\text { Pressure recovered } \\
(\mathrm{MPa})\end{array}$} & \multirow[b]{2}{*}{ Comments } \\
\hline & & & & & Logged $^{\dagger}$ & Gauge ${ }^{\ddagger}$ & \\
\hline \multicolumn{8}{|c|}{ 311-U1325B- } \\
\hline $11 \mathrm{P}$ & 82.4 & 88 & 88 & 22.9 & 0 & - & Pressure lost \\
\hline $17 \mathrm{E}$ & 129.9 & 56 & 56 & 23.3 & 0 & - & Core liner broke at core catcher \\
\hline $22 \mathrm{Y}$ & 169.4 & 17 & 17 & 23.7 & 0 & - & Valve did not close; sediments washed out of core \\
\hline $26 \mathrm{E}$ & 197.4 & 28 & 28 & 24.0 & 0 & - & Deformed liner prevented valve from closing \\
\hline $28 \mathrm{P}$ & 206.1 & 46 & 46 & 24.1 & 0 & - & PCS stuck beyond main bit; pipe trip required \\
\hline \multicolumn{8}{|c|}{ 311-U1325C- } \\
\hline $5 Y$ & 217.6 & 0 & 0 & 24.2 & 21.7 & 22.0 & Damaged core catcher; water core only \\
\hline 10P & 256.1 & 98 & 96 & 24.6 & 12.4 & 1.5 & Normal operation \\
\hline
\end{tabular}

Notes: Water depth at Site U1325 is 2195 mbsl. P = Pressure Core Sampler (PCS), Y = Fugro Percussion Corer (FPC), E = HYACE Rotary Corer $(\mathrm{HRC}) .{ }^{*}=$ based on X-ray imaging and gamma ray density profiling prior to degassing. $\dagger=$ last pressure recorded before data logger disconnected from corer autoclave. Temperature $2^{\circ}-4^{\circ} \mathrm{C}$ unless otherwise noted. $\ddagger=$ pressure measured when autoclave pressure transducer connected to computer (PCS cores) or external gauge (PCS, FPC, HRC cores). Pressure measured at $7^{\circ} \mathrm{C}$ unless otherwise noted.

Table T17. In situ conditions of PCS cores recovered from Site U1325.

\begin{tabular}{ccccccc}
\hline & \multicolumn{2}{c}{ Depth (mbsf) } & & & & \\
Core & Top & Bottom & $\begin{array}{c}\text { Pemerature } \\
\left({ }^{\circ} \mathrm{C}\right)\end{array}$ & $\begin{array}{c}\text { Pressure } \\
(\mathrm{MPa})\end{array}$ & $\begin{array}{c}\text { Background } \\
\text { salinity }\end{array}$ & $\begin{array}{c}\text { Methane } \\
\text { saturation } \\
(\mathrm{mM})\end{array}$ \\
\hline $\begin{array}{l}311-\mathrm{U} 1325 \mathrm{C}- \\
10 \mathrm{P}\end{array}$ & 256.1 & 257.1 & 18.4 & 24.6 & 34 & 143.2 \\
\hline
\end{tabular}

Notes: Background salinity was extrapolated from adjacent cores (Table T3). Temperature was calculated from sediment depth assuming a seafloor temperature of $3.03^{\circ} \mathrm{C}$ and a thermal gradient of $60.0^{\circ} \mathrm{C} / \mathrm{km}$. Pressure was calculated from sediment and water depth $(2195 \mathrm{mbsl})$. Methane saturation was calculated based on sediment and water depth, seafloor temperature, thermal gradient, and salinity according to Xu $(2002,2004)$. 
Table T18. Results from degassing experiments, Site U1325.

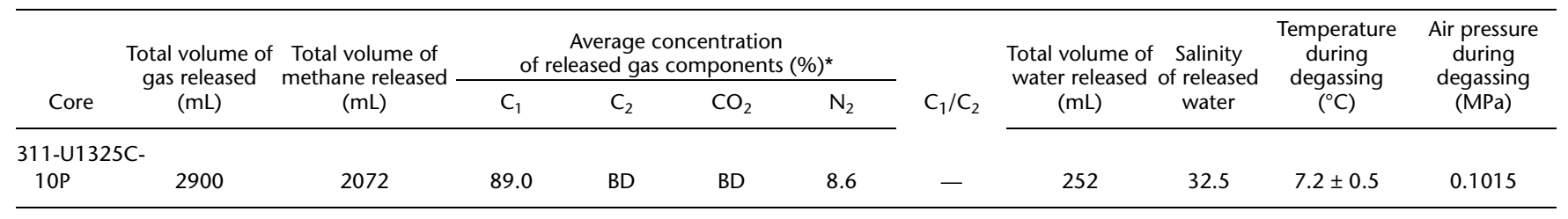

Notes: ${ }^{*}=$ excludes initially released gas increments that are diluted by dead volume of manifold system. $\mathrm{BD}=$ below detection. $-=$ not applicable.

Table T19. Characteristics of PCS cores used for mass balance calculations, Site U1325.

\begin{tabular}{|c|c|c|c|c|c|c|c|c|}
\hline Core & $\begin{array}{c}\text { Core } \\
\text { length } \\
\text { recovered } \\
(\mathrm{m})\end{array}$ & $\begin{array}{l}\text { Sediment } \\
\text { volume } \\
\text { in inner core } \\
\text { barrel }(\mathrm{mL})\end{array}$ & $\begin{array}{c}\text { Porosity } \\
\text { (\%) }\end{array}$ & $\begin{array}{l}\text { Pore water } \\
\text { volume } \\
\text { in inner core } \\
\text { barrel }(\mathrm{mL})\end{array}$ & $\begin{array}{c}\text { Volume } \\
\text { of water } \\
\text { in outer core } \\
\text { barrel }(\mathrm{mL})\end{array}$ & $\begin{array}{l}\text { Sediment extruded } \\
\text { with outer core } \\
\text { barrel water, dry } \\
\text { weight (g) }\end{array}$ & $\begin{array}{l}\text { Headspace } \\
\text { volume } \\
\text { in outer core } \\
\text { barrel }(\mathrm{mL})\end{array}$ & $\begin{array}{c}\text { Salinity } \\
\text { of water } \\
\text { in outer core } \\
\text { barrel }\end{array}$ \\
\hline \multicolumn{9}{|c|}{ 311-U1325C- } \\
\hline $10 \mathrm{P}$ & 0.98 & 1436 & 44 & 638 & 2325 & 230 & 639 & - \\
\hline
\end{tabular}

Note: $-=$ no data.

Table T20. Mass balance calculations based on degassing experiments, Site U1325.

\begin{tabular}{|c|c|c|c|c|c|c|c|c|c|c|c|c|}
\hline \multirow[b]{3}{*}{ Core } & & & \multirow{3}{*}{$\begin{array}{c}\text { Total } C_{1} \\
\text { released } \\
\left(10^{-3} \text { mole }\right)\end{array}$} & \multicolumn{5}{|c|}{$\mathrm{C}_{1}$ concentration $(\mathrm{mM})$} & \multirow{2}{*}{\multicolumn{2}{|c|}{$\begin{array}{l}\text { In situ nondissolved } C_{1} \\
\text { as percentage of pore } \\
\text { volume if present as }\end{array}$}} & \multicolumn{2}{|c|}{$\begin{array}{l}\text { Potential pore water } \\
\text { freshening caused } \\
\text { by gas hydrate } \\
\text { decomposition }\end{array}$} \\
\hline & \multicolumn{2}{|c|}{ Depth (mbsf) } & & \multirow[b]{2}{*}{ Total } & \multicolumn{2}{|c|}{ At laboratory conditions } & \multicolumn{2}{|c|}{ In situ } & & & \multirow{2}{*}{$\begin{array}{c}\text { Water } \\
\text { release }(\mathrm{mL})\end{array}$} & \multirow{2}{*}{$\begin{array}{l}\text { Freshening } \\
\text { (\%) }\end{array}$} \\
\hline & Top & Bottom & & & Dissolved* & Free $^{\dagger}$ & Dissolved ${ }^{\ddagger}$ & Nondissolved & Free gas & Gas hydrate & & \\
\hline \multicolumn{13}{|c|}{ 311-U1325C- } \\
\hline $10 P$ & 256.1 & 257.1 & 110 & 175 & 3.0 & 172 & 143.2 & 32 & 0.3 & 0.4 & 2 & 0.3 \\
\hline
\end{tabular}

Notes: * = extrapolated from headspace analysis of Sample 311-U1325C-9X4, 120-123 cm. $\dagger=$ calculated based on the total amount of $\mathrm{C}_{1}$ released during the degassing experiment and the pore water volume recovered by the PCS, $\ddagger=$ methane saturation from Table T17. 